\title{
Metamorphism, geochronology and stratigraphy of an amphibolite-facies greenstone-hosted gold deposit: \\ Plutonic Gold Mine, Marymia Inlier, Western Australia
}

\author{
by \\ Michael Fuller Gazley \\ A thesis submitted to Victoria University of Wellington \\ in fulfilment of the requirements for the degree of \\ Doctor of Philosophy \\ in Geology
}

Geology Department

School of Geography, Environment and Earth Sciences

Victoria University of Wellington, New Zealand

2011 
In memory of

\section{F L Fuller \\ \& \\ W V Gazley}

Two men who inspired me to ask questions 


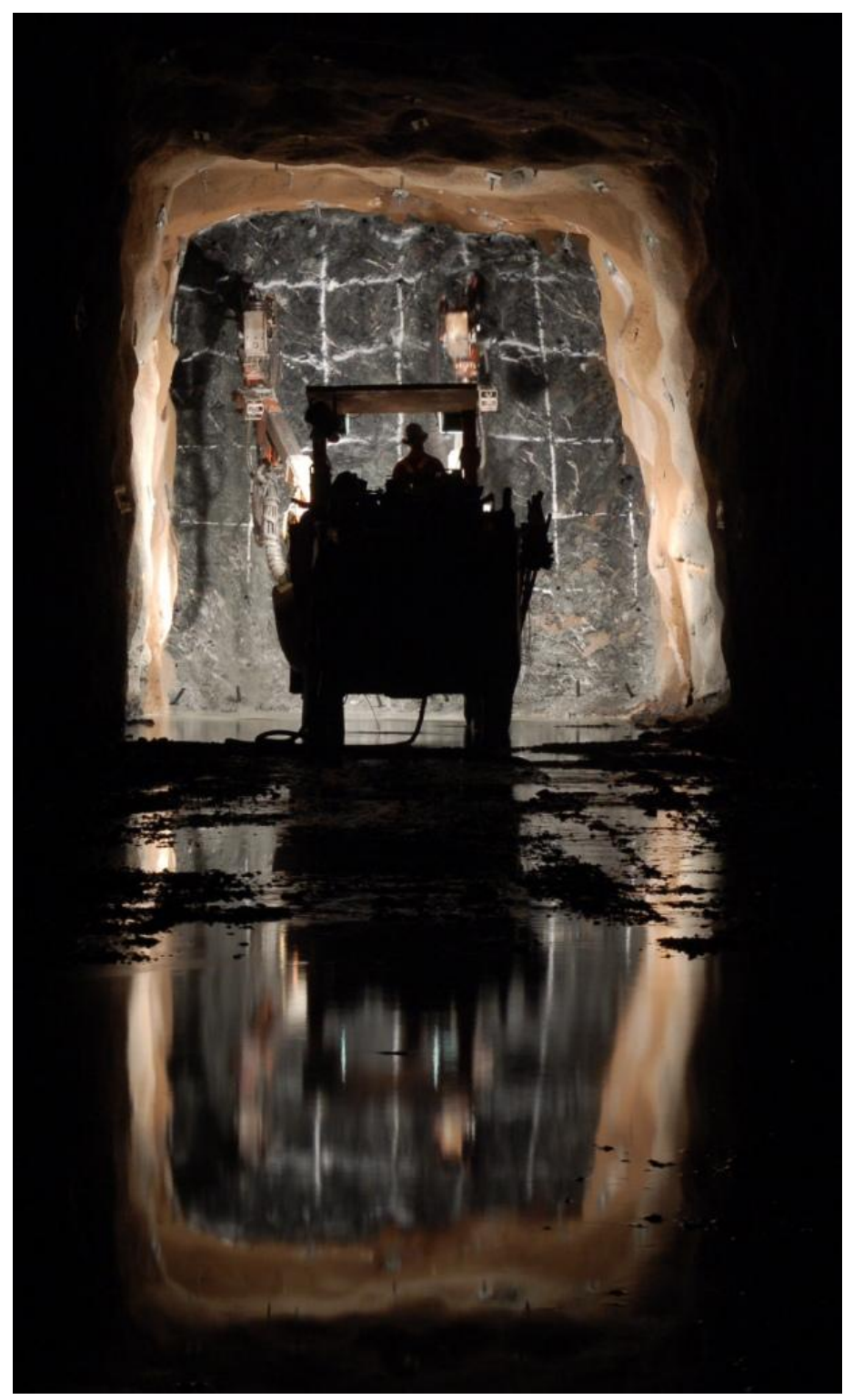

A jumbo working in the BD3959WDD. 


\title{
ABSTRACT \\ METAMORPHISM, GEOCHRONOLOGY AND STRATIGRAPHY OF AN AMPHIBOLITE-FACIES GREENSTONE-HOSTED GOLD DEPOSIT: PLUTONIC GOLD MINE, MARYMIA INLIER, WESTERN AUSTRALIA
}

\author{
Michael F. Gazley \\ Under the supervision of Dr. Julie Vry and Prof. Joel Baker \\ with Dr. Monica Handler and Dr. Marc-Alban Millet
}

A significant proportion of the world's Au occurs in the metamorphosed mafic rocks of Archaean greenstone belts. In such deposits, the original stratigraphy and its possible role in localising Au mineralisation can be difficult to discern due to a lack of distinctive marker units and the mineralogically and texturally monotonous nature of the metabasaltic host rocks. Understanding the effects of metamorphism, deformation, and alteration on these largely uniform host rocks, which may have experienced multiple generations of $\mathrm{Au}$ mineralisation, is essential for finding and extracting $\mathrm{Au}$ from within those deposits, and for discovering new greenstone-hosted Au deposits.

This study examines the effects of primary stratigraphy on Au mineralisation, the conditions and possible controls on metamorphism, and the timing of Au mineralising events at Plutonic Gold Mine (Plutonic), Plutonic Well Greenstone Belt (PWGB), Marymia Inlier, Western Australia. Questions that remain unresolved in over 20 years of mining can now be addressed utilising advances in portable X-Ray fluorescence (pXRF), thermodynamic modelling of mineral activities and geochronological techniques. 
The stratigraphy of the Au-mineralised amphibolite-facies metabasalts that comprise the mine sequence at Plutonic has been examined using pXRF techniques. The results illustrate a geochemical stratigraphy in which individual lava flows can be identified on the basis of element concentrations. The most evolved basalts are at the structural base of the succession, and the least evolved at the top of the sequence. This confirms previous geochemical interpretations and textural evidence that the sequence is overturned, and demonstrates for the first time that the presented section does not involve significant structural repetition. In conjunction with Au assay data, the pXRF data reveal that Au typically occurs along basalt flow boundaries. The elemental concentration data clearly demonstrate stratigraphic control on Au mineralisation that is not readily apparent at the macroscopic level.

Results of $P-T$ pseudosection calculations in the NCFMASHTOS $\left(\mathrm{Na}_{2} \mathrm{O}-\mathrm{CaO}-\mathrm{FeO}-\right.$ $\mathrm{MgO}-\mathrm{Al}_{2} \mathrm{O}_{3}-\mathrm{SiO}_{2}-\mathrm{H}_{2} \mathrm{O}-\mathrm{TiO}_{2}-\mathrm{O}-\mathrm{SO}_{2}$ ) system are presented for two typical metabasaltic rocks from the Plutonic. Those results, together with changes in mineral compositions and mineral assemblages observed in the rocks, are used to argue that a previously-unrecognised steep pressure increase (from $\sim 3-4 \mathrm{kbar}$ at $\sim 500{ }^{\circ} \mathrm{C}$ to $\geq 8$ kbar at $\sim 600{ }^{\circ} \mathrm{C}$ ) accompanied metamorphism to peak temperatures. Existing models for the early evolution of the PWGB involve nappe stacking supported by relatively cold strong crust, with little overall change in thickness and with peak metamorphism at temperatures similar to those reported here, but with pressures of $\sim 4 \mathrm{kbar}$.

Prior to this study the main episode of Au mineralisation in the PWGB was interpreted to either have accompanied or shortly followed the attainment of peak metamorphic conditions in the late Archaean at $2650 \mathrm{Ma}$. New Pb-isotope results reveal that the majority of Au-associated sulphides at Plutonic are Proterozoic in age, 
at $\sim 2200 \mathrm{Ma}$, suggesting that Au-mineralisation may have been widespread in the inlier and associated cratonic areas at that time. Later Au-mineralising events have also been constrained at $\sim 1830 \mathrm{Ma}$, and at 1730-1660 Ma. Rb-Sr data from a biotite from Plutonic possibly indicates that the metamorphism was followed by a protracted period of slow cooling. Alternatively, the biotite data may reflect some combination of resetting, probably related to metasomatic events associated with Au mineralisation at $\sim 2200 \mathrm{Ma}$, or with the Capricorn Orogeny at $\sim 1830 \mathrm{Ma}$, and cooling. A further metasomatic event at $\sim 1720 \mathrm{Ma}$ is dated by both $\mathrm{U}-\mathrm{Pb}$ dating of zircon overgrowths, and a new ${ }^{207} \mathrm{~Pb}^{2}{ }^{206} \mathrm{~Pb}$ age from a hydrothermal sphene in chlorite-carbonate vein of $1725 \pm 26 \mathrm{Ma}$. This metasomatic event was probably associated with $\mathrm{Au}$ mineralisation, as the $\mathrm{Pb}$-isotope ages for the final $\mathrm{Au}$-mineralising event range from 1730-1660 Ma. 


\section{ACKNOWLEDGEMENTS}

First and foremost, thanks must go to my primary supervisor, Julie Vry; without her guidance, effort and encouragement I could never have made it through this project. Her multi-coloured edits have gained notoriety, but they are the single most effective tool I know for bashing a student's writing into shape, and as painful as they were to write, they were equally painful to receive and do damage control on afterwards. I will forever be in her debt for her enthusiasm and commitment.

Joel Baker, Monica Handler and Marc-Alban Millet deserve thanks for coaching and coaxing a metamorphic and economic geologist through the perils of ultra-clean lab work and geochronology. Stewart Bush, Richard Wysoczanski, John Patterson and Chelsea Tutt are acknowledged for their assistance with making, mounting and analysing thinsections in the microprobe.

I have to acknowledge Matt Stevens, Katie Collins and Sarah Grain for sharing their honours and masters years with me, and providing comments and feedback on my work throughout. The three of them and coffee have kept me sane. Jamie Boorman is thanked for the hours that he spent keeping me company on the microprobe on those late-night runs and for his assistance in making THERMOCALC draw lines when I had all but given up. Thanks too, to all the other students at Victoria University who directly or indirectly have had a bearing on this project - the list of names would fill a page. 
Ettienne du Plessis is entirely responsible for bringing this study to be. Without his faith that a young Kiwi geologist who appeared on site as a vacation student had the ability to do this project (as an MSc, as it was then planned), I wonder where I would be today? His enthusiasm for rocks is infectious, and the financial and logistical backing that he, and Barrick Gold Australia Pacific have provided has been amazing. The assistance and ongoing support of Ray Swanson, Sam de Beer, Sue Murray, Kathi Dilworth and the rest of the geologists at Plutonic is also gratefully acknowledged.

Roger Powell, Katy Evans and Johann Diener are gratefully acknowledged for their input with THERMOCALC and the modelling of phase equilibria in mafic rocks. Discussions with Rob Hough, John Walshe, Steve Barnes and Guillaume Duclaux have greatly improved my understanding of structure, tectonics, host rock and gold mineralising systems. Input from Kevin Cassidy on $\mathrm{Pb}$-isotopes and his tour of the Alchemy Resources' site at Three Rivers, on the edge of the Marymia Inlier, is also gratefully acknowledged.

Reviews by the following people have greatly improved the chapters: K. Howard Poulsen, Rob Kerrich, Katy Evans, Johann Diener, Steve Barnes, Richard White, and two anonymous reviewers.

To my long-suffering partner throughout these last six years, Annette Pocock; you got me to Plutonic in the first place, and you have stuck with me through thick and thin. I know you most definitely wanted to be doing something more exciting with your life (like go to the beach...) than wait for me to emerge from working on my laptop to 
decide I had done enough to be allowed out for the day. Your encouragement and motivation to keep me focussed to get this thesis finished has been amazing, and your editing is always greatly appreciated - especially turning my sentences around the right way and reminding me "subject, object, verb" everytime I wrote a long convoluted sentence. I cannot thank you enough.

Finally, and perhaps most importantly I have to thank my parents, Dennis and Frances Gazley, for their ongoing support and encouragement and for providing me with somewhere to live for my university career. I would never have got this far without you. Also, my brother, Scott Gazley; your humour, entertainment and camaraderie is always enjoyable.

If I have omitted anyone, I apologise, and I thank you all the same.

\author{
M. F. Gazley
}

08 November 2011 


\section{CONTENTS}

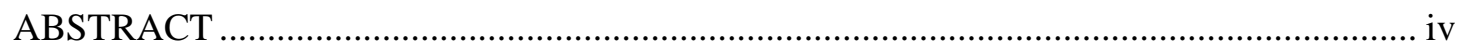

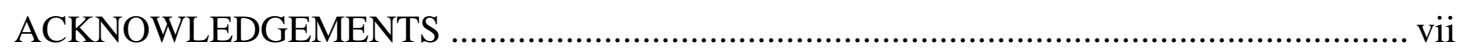

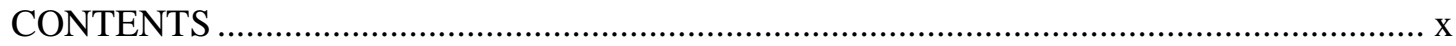

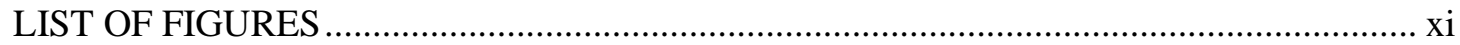

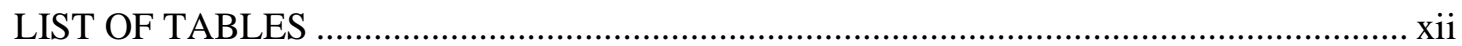

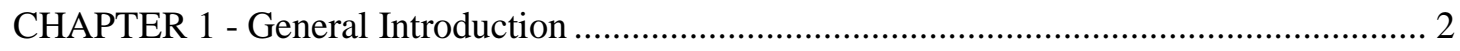

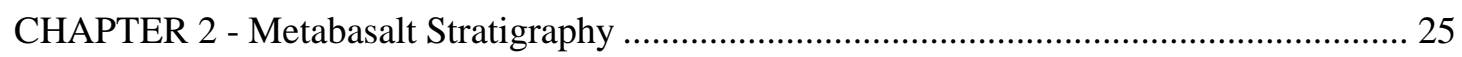

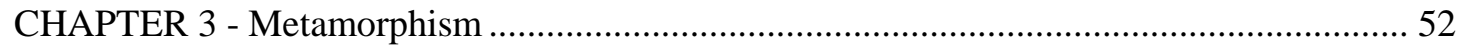

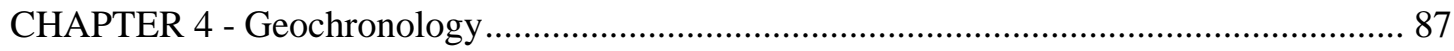

CHAPTER 5 - Key outcomes, implications and future work ......................................... 120

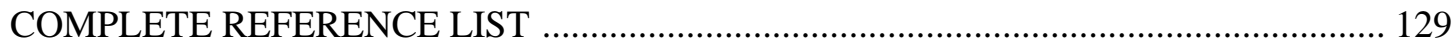

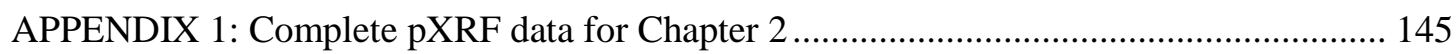

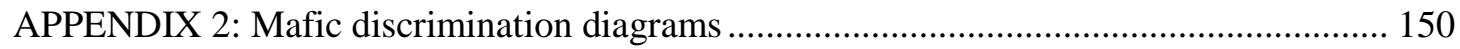

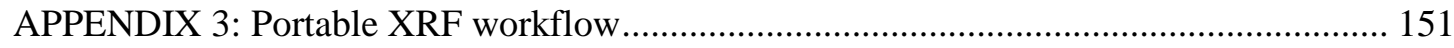

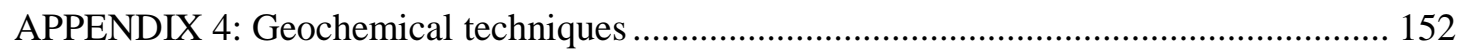

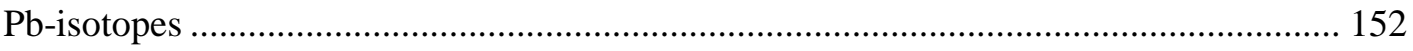

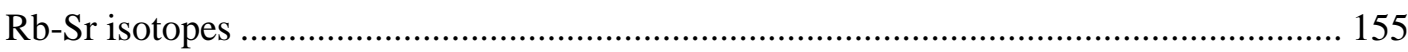

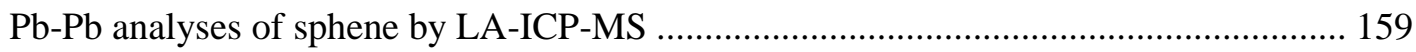

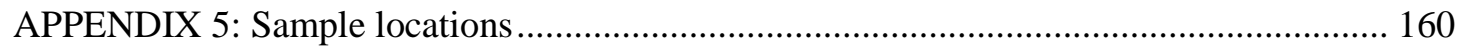

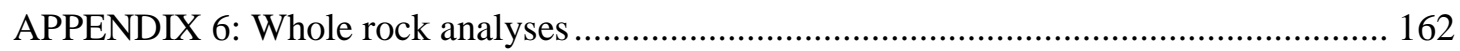




\section{LIST OF FIGURES}

Figure 1.1 Simplified location and geological map for Plutonic Gold Mine. 3

Figure 1.2 Geological map for the Marymia Inlier. 5

Figure 1.3 Simplified stratigraphic column for the greater Plutonic area..................12

Figure 1.4 Leapfrog 3D ${ }^{\mathrm{TM}}$ screenshots showing the Mine Mafic Package ................. 13

Figure 1.5 Examples of brown-lode style mineralisation ...................................... 14

Figure 1.6 Summary diagram of geological events at Plutonic Gold Mine ...............17

Figure 2.1 Simplified location and geological map for Plutonic Gold Mine ............22

Figure 2.2 Examples of typical metabasalt and minor metasediments .....................31

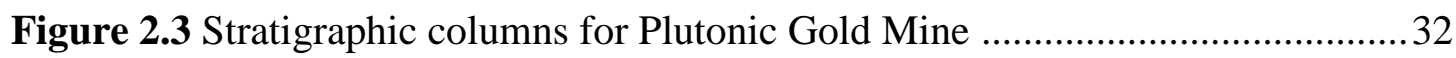

Figure 2.4 pXRF data for a representative section of the Mine Mafic Package ..........38

Figure 3.1 Simplified location and geological map for Plutonic Gold Mine .............54

Figure 3.2 Petrography of metabasalt samples from Plutonic Gold Mine .................64

Figure 3.3 $P$-T pseudosection for metabasalt MG313 (NCFMASHTOS system) .....68

Figure 3.4 $P$-T pseudosection for metabasalt MG053 (NCFMASHTOS system) .....69

Figure 3.5 Contoured $P-T$ pseudosections for metabasalt MG053 _....................... 71

Figure 3.6 Overlain $P$-T pseudosections for metabasalts MG053 and MG313 _........73

Figure 4.1 Simplified location and geological map for Plutonic Gold Mine .............90

Figure 4.2 Petrography of Au-mineralised samples from Plutonic Gold Mine .........94

Figure 4.3 Conchordia diagram showing ${ }^{206} \mathrm{~Pb} /{ }^{204} \mathrm{~Pb}$ and ${ }^{207} \mathrm{~Pb} /{ }^{204} \mathrm{~Pb}$ isotope ratios for sulphide minerals from the Plutonic Well Greenstone Belt .................................. 103

Figure 5.1 Unpublished, raw pXRF data for north-south long section .................. 122

Figure 5.2 Figure from Rey et al. (2003) to explain the concept of gravity-driven, or vertical, tectonics

Figure 5.3 Summary diagram of geological events at Plutonic Gold mine 127 


\section{LIST OF TABLES}

Table 2.1 Lower limit of determination for selected elements by pXRF 36

Table 2.2 Conventional XRF analyses and pXRF analyses for the same samples ......38

Table 3.1 Bulk rock compositions as input for $P-T$ pseudosection ...........................61

Table 3.2 Representative electron microprobe analyses for sample MG053 .............62

Table 3.3 Representative pressures and temperatures for sample MG053 ................63

Table 4.1 ${ }^{87} \mathrm{Rb} /{ }^{86} \mathrm{Sr}$ and ${ }^{87} \mathrm{Sr} /{ }^{86} \mathrm{Sr}$ ratios for samples from Plutonic Gold Mine ..... 101

Table 4.2 Pb-isotope ratios for sphene from Plutonic Gold Mine ........................... 101

Table 4.3 Pb-isotope compositions of sulphides from Plutonic Gold Mine ............ 102

Table 4.4 Pb-isotope compositions of sulphides from the PWGB ..........................111 


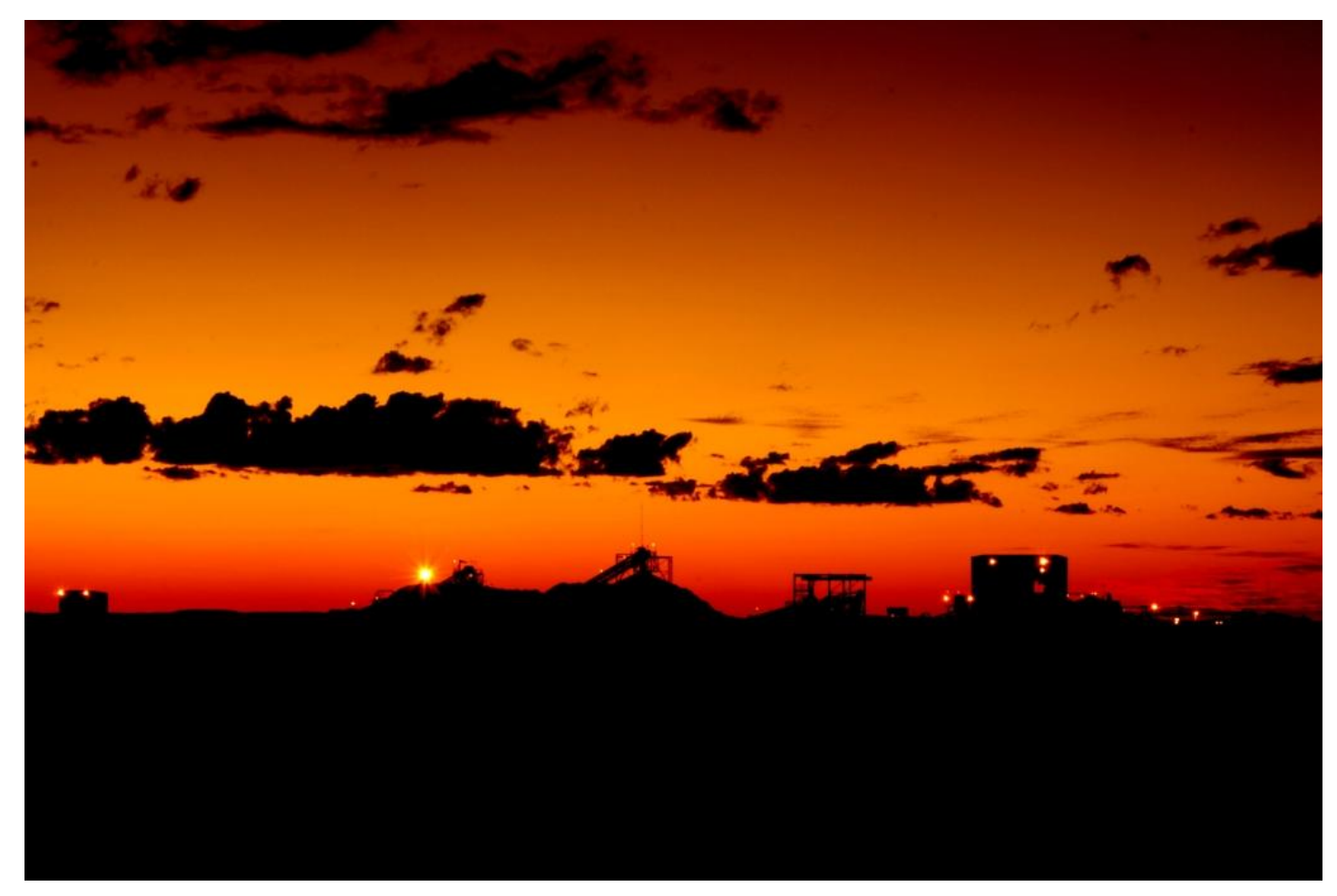

The ROM pad on dusk. 


\section{CHAPTER 1 \\ GENERAL INTRODUCTION}

\section{Research problem}

In 1991, Barnicoat et al. stated that current understanding of Archaean lode-Au mineralisation was biased towards the giant deposits such as Kalgoorlie, in the Eastern Goldfields province of Western Australia, and Timmins, in Ontario, Canada; both of which are hosted within greenstone belts that have undergone relatively lowgrade metamorphism to greenschist facies or greenschist-amphibolite transition conditions. Even 20 years on, Au deposits from higher-grade metamorphic settings have received comparatively little attention in the literature. The comparative rarity of known deposits from higher-grade metamorphic settings, and their more subtle geological expression (e.g. Groves et al., 1992; Groves, 1993; Mikucki \& Ridley, 1993), does not mean that such deposits are of little economic value. Plutonic Gold Mine (Plutonic), located in amphibolite-facies metamorphic rocks in Western Australia (Fig. 1) is a giant deposit, with a total endowment of $\sim 10.5$ million oz (Fallon et al., 2010). Evaluating how such a deposit fits into our evolving understanding of Au deposits requires first that the geological history is well understood.

\section{Plutonic Gold Mine, Marymia Inlier}

Plutonic is hosted in amphibolite-facies metamorphic rocks of the Plutonic Well Greenstone Belt (PWGB), in the Marymia Inlier, a sliver of Archaean crust, surrounded by Proterozoic rocks, located to the north of the Yilgarn Craton and just to the south of the Pilbara Craton (Fig. 1.1). Uncertainty remains as to whether the Marymia Inlier is continuous with the Yilgarn Craton below the current level of 


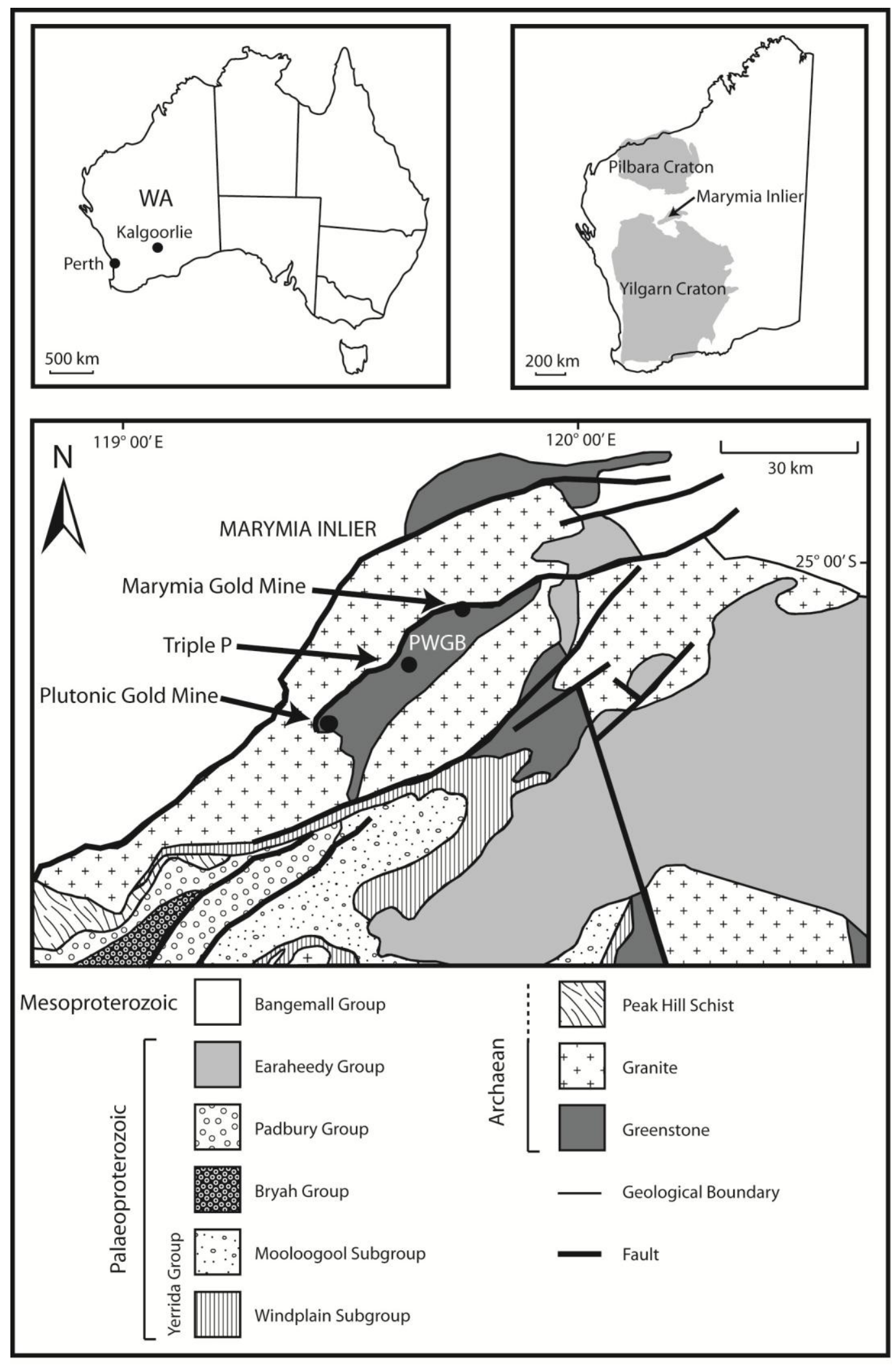

Figure 1.1 Simplified location and geological map for the Marymia Inlier modified after Bagas (1999). Insets show location of Marymia Inlier in Australia, and in relation to the Pilbara and Yilgarn cratons in Western Australia (modified after Tyler and Hocking, 2002). PWGB = Plutonic Well Greenstone Belt. Significant Au deposits are labelled. 
exposure (cf. Champion \& Cassidy, 2007). The metamorphic grade and current craton-margin setting of the inlier indicate a complex history for the area as noted by previous workers. Vielreicher et al. (2002) reported that "Archaean gold mineralisation at Marymia [Gold Mine, (Figure 1.2) at the northern end of the PWGB], is broadly synchronous with peak metamorphism, but has a more complex setting relative to the 'typical' Archaean gold deposit hosted within amphibolite facies rocks in the Yilgarn Craton.”. McMillan (1996) and Vickery (2004) maintained a similar opinion for Plutonic. Certainly, Plutonic differs markedly from the more typical (greenschist-facies) Au deposits of the Eastern Goldfields, Yilgarn Craton (e.g. Witt; 1991), and in the context of interpretive models based largely on those deposits (e.g. Groves et al., 1992; Groves, 1993).

\section{Genetic models for Au deposit formation}

Some of the largest goldfields on the planet contain more than 1,000 $\mathrm{t}$ of Au with grades $10-30 \mathrm{~g} / \mathrm{t}$ or better; this represents an enrichment of the crustal abundance on the order of 10,000 times (Phillips \& Groves, 2010). Almost all current models for formation of such deposits require the transport of $\mathrm{Au}$ and associated components in a hydrothermal fluid. Thus, such models focus on the timing of fluid flow, the origin of the fluid, the nature of the fluid pathways, and the sites of and controls on $\mathrm{Au}$ deposition from the fluid.

The crustal continuum model of Groves et al. (1992) and Groves (1993) used evidence from Au deposits world-wide to argue that deposits form throughout a variety of crustal regimes under conditions representative of a continuous section through at least $15 \mathrm{~km}$ of the crust, from $\sim 180{ }^{\circ} \mathrm{C}$ at $<1 \mathrm{kbar}$ to $700{ }^{\circ} \mathrm{C}$ at $5 \mathrm{kbar}$. The 


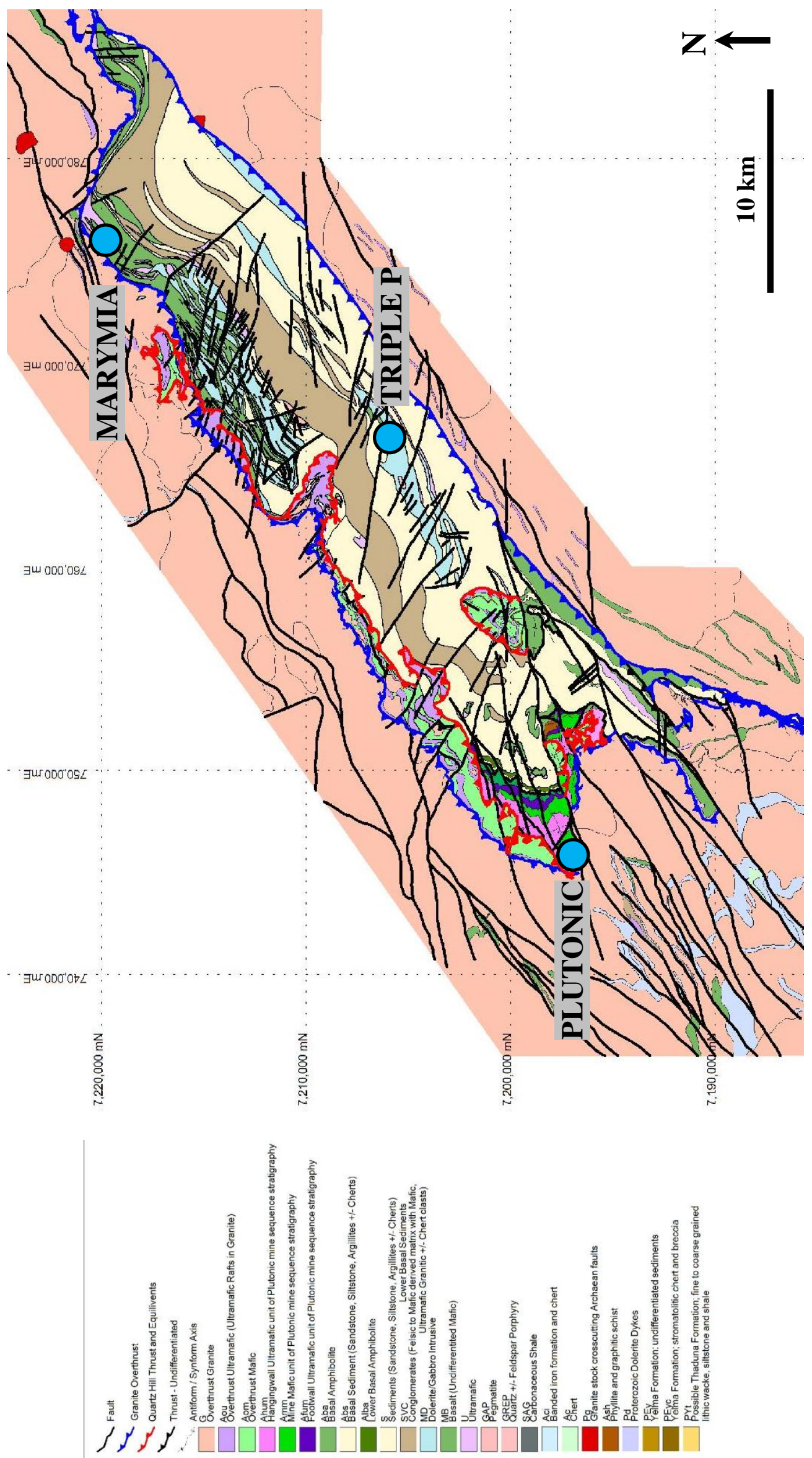

Figure 1.2 Geological map for the Marymia Inlier, courtesy of Barrick (Australia Pacfic) Ltd. 
Au mineralisation is described in terms of changes in morphology of the hosting quartz veins, which range from plumose, comb and cockade textures and vug-fillings in low-grade metamorphic settings, to intermediate settings where the quartz veins are massive/bucky with laminated quartz and partial annealing textures; to high-grade settings, where coarse-grained veins occur. Alteration accompanies the veining, producing the following typical mineral assemblages (listed from lowest to highest metamorphic grade): ankerite/dolomite-white mica-chlorite; ankerite/dolomite-white mica-biotite-chlorite \pm albite; amphibole-biotite-plagioclase; diopside-biotitegarnet \pm K-feldspar (e.g. Groves, 1993; Mickuki \& Ridley, 1993).

Recently, the crustal continuum model has been questioned (Phillips \& Powell, 2009; 2010). The key criticism of the continuum model is that in deposits from the highest metamorphic grades, a major Au-forming hydrothermal event at peak metamorphic conditions would require the introduction of an aqueous fluid, which would flux partial melting, or be consumed to produce further melt.

Instead, Phillips \& Powell (2010) offer a metamorphic devolatilisation model for the formation of Au deposits. In this model hydrated and carbonated greenschist facies rocks, particularly metabasic rocks, are devolatilised primarily across the greenschistamphibolite facies transition in an orogenic setting. Devolatilisation works on a grainscale (e.g. Phillips \& Powell, 2010), extracting $\mathrm{H}_{2} \mathrm{O}, \mathrm{CO}_{2}, \mathrm{~S}$ and Au effectively from large bodies of rock. The low salinity nature of this fluid ensures low base metal concentrations in the auriferous metamorphic fluid. This fluid migrates through the crust via zones of weakness (e.g. shears, faults, along primary stratigraphic boundaries) until $\mathrm{Au}$ is deposited by reduction of the Au-bearing fluid in contact with 
reduced carbon-bearing rocks and/or by sulphidation of wallrocks. The correlation of major deposits with rock type, even when Au is hosted primarily within veins, is used to argue for a rock-dominated depositional system, and not a fluid-dominated one (Phillips \& Powell, 2010).

Another well-established classification scheme (Groves et al., 1998), based primarily on Yilgarn and Canadian deposits, considers the deformation setting, but also emphasises a quartz vein association for the Au. Groves et al. (1998) wrote: “... socalled 'mesothermal' gold deposits are associated with regionally metamorphosed terranes of all ages. Ores were formed during compressional to transpressional deformation processes at convergent plate margins in accretionary and collisional orogens ... The resulting gold-bearing quartz veins are emplaced over a unique depth range for hydrothermal ore deposits, with gold deposition from $15-20 \mathrm{~km}$ to the near surface environment."

\section{Plutonic Gold Mine and genetic models}

Plutonic fits poorly into the context of models based largely or in part on the Eastern Goldfields setting (e.g. Witt, 1991; Groves et al., 1992; Groves, 1993; Groves et al., 1998). Plutonic is not a quartz vein-hosted deposit, and differs in many other ways when compared to the Au deposits in the Eastern Goldfields province of the Yilgarn Craton.

The main episode of Au mineralisation at Plutonic is hosted within altered mafic or rare intercalated metasedimentary rocks, and is typically confined to well-defined lodes. The alteration halos are narrow, and both chlorite and albite, and diopside are 
absent, placing Plutonic in the "amphibole" deposit class of Mickuki \& Ridley (1993). This is consistent with previous metamorphic constraints determined for Plutonic by Vickery (2004) and for the Marymia Inlier by McMillan (1996) of $600{ }^{\circ} \mathrm{C}$ and $550{ }^{\circ} \mathrm{C}$ respectively, with pressures $\sim 2-4$ kbar. The mechanism for this metamorphism was thought to be thrust stacking with minimal crustal thickening (Bagas, 1999). This contrasts with the Eastern Goldfields province where, late syn-tectonic granitoids are inferred to have acted as centres of heat and fluid flux in large-scale, synmetamorphic, hydrothermal systems that deposited $\mathrm{Au}$, possibly from modified mantle-derived fluids (Witt, 1991).

Witt (1991) noted that alteration assemblages in the Eastern Goldfields province vary systematically with increasing regional metamorphic grades, and that higher metamorphic grades commonly occur in broad metamorphic aureoles around late syntectonic granitic intrusions. These relationships are interpreted to suggest that granitoid intrusion, regional metamorphism and Au mineralisation were broadly contemporaneous, during the final stages of the tectonic evolution of the granitegreenstone terrane. In contrast, at Plutonic, all of the available evidence indicates that the highest-grade metamorphic conditions accompanied regional, not contact, metamorphism and the emplacement of granites significantly pre-dated the onset of peak metamorphism. The local granites were intruded before $2720 \mathrm{Ma}$, and crosscutting felsic intrusions before $2680 \mathrm{Ma}$, some $20 \mathrm{Myr}$ before the onset of peak regional metamorphism within the inlier at 2660 Ma (McMillan, 1996; Vielreicher \& McNaughton, 2002; Vielreicher et al., 2002; Vickery, 2004). 
In the Yilgarn Craton, the majority of workers infer that Au deposition was broadly synchronous with peak metamorphic conditions, in the late Archaean between 2660$2630 \mathrm{Ma}$ (e.g. Barnicoat et al., 1991; Groves et al., 1995; Vielreicher et al., 2002; Robert et al., 2005; Vielreicher et al., 2010). The main episode of Au mineralisation in the Marymia Inlier has long been interpreted to have occurred at $\sim 2650 \mathrm{Ma}$ (McMillan, 1996; Vielreicher et al., 2002), but there is clear evidence that younger Proterozoic-age Au mineralisation events have also taken place at Plutonic (McMillan, 1996; Vickery, 2004; this study).

Plutonic is an enigmatic, unusual, and possibly unique deposit that, since the start of its mine life, has been understudied. However, the key controls on Au mineralisation are present: stratigraphy, metamorphic conditions, and host-rock chemistry. It is often difficult to discern the conditions, timing and influence of each in focusing significant amounts of Au into geographically small areas. This study has adopted a multi-faceted approach in order to improve understanding of the geology and Au mineralisation at Plutonic. From the brief evaluation above it is apparent that based on our current level of understanding Plutonic does not fit well into the crustal continuum model for $\mathrm{Au}$ deposits; the model appears not be applicable here. The metamorphic model of Phillips \& Powell (2010) may explain many of the features that we see at Plutonic better than older models. However, we need to understand the deposit better to be able to make a full assessment.

\section{Plutonic Local Geology}

Plutonic is an underground mine located approximately $800 \mathrm{~km}$ north-east of Perth, Western Australia (Figure 1.1), at the southern end of the Plutonic Well Greenstone 
Belt (Figure 1.2), in the Marymia Inlier, between the Yilgarn and Pilbara cratons. In 20 years of production, over four million oz of Au have been produced from Plutonic, and the deposit has a total Au endowment of $\sim 10.5$ million oz (Fallon et al., 2010). Based on U-Pb dating of zircons from cross-cutting intrusive units, rocks in the Plutonic Well Greenstone Belt were deposited before $2680 \mathrm{Ma}$ and metamorphosed to amphibolite-facies conditions at 2660-2630 Ma (McMillan, 1996; Bagas, 1999; Vielreicher et al., 2002; Vickery, 2004). Prior to this study, peak metamorphic conditions at Plutonic were considered to be $\sim 4 \mathrm{kbar}$ and $\sim 600{ }^{\circ} \mathrm{C}$ (McMillan, 1996; Vielreicher et al., 2002; Vickery, 2004). However, based on results from both traditional geothermobarometry and forward modelling using THERMOCALC this study has shown that pressures were significantly higher, at $\geq 8 \pm 2$ kbar and $\sim 600 \pm$ $50^{\circ} \mathrm{C}$.

The early history of the PWGB is comparable to that of greenstone sequences in the Yilgarn Craton, and later features are attributable to suturing events during the Palaeoproterozoic Capricorn Orogeny that brought together the Pilbara and Yilgarn cratons to form the West Australian Craton at 1830 Ma (Vielreicher et al., 2002; Cawood \& Tyler, 2004; Pirajno et al., 2004). The major Au mineralisation event occurred in the north of the PWGB at $\sim 2650 \mathrm{Ma}$, and at $\sim 2200 \mathrm{Ma}$ at the southern (Plutonic) end of the belt, based on results of $\mathrm{Pb}$-isotope model ages of sulphide minerals (McMillan, 1996; Vielreicher et al., 2002; Gazley et al., submitted (Chapter 4)). Two later Au mineralising events followed, one at $1830 \mathrm{Ma}$, in the Capricorn Orogeny (Vickery, 2004; Pirajno et al., 2004; Gazley et al., submitted (Chapter 4)), and a subsequent one at $\sim 1720 \mathrm{Ma}$, probably syn- or post- an hydrothermal event, 
that deposited base-metal associated Au (Vielreicher et al., 2002; Gazley et al., submitted (Chapter 4)).

Gold at Plutonic is for the most part hosted in a sequence of metamorphosed mafic amphibolites, that is locally known as the Mine Mafic Package. Morgan (2004) used conventional XRF analyses to show that in the Plutonic area this package consists predominantly of high Fe- to high Mg-tholeiitic rocks. Pillow structures are commonly preserved, especially in low-strain areas, and show that deposition occurred in a submarine environment. A detailed stratigraphy of the Mine Mafic Package has proven difficult to resolve as there are very few distinct and continuous marker horizons (a general stratigraphic column is presented in Figure 1.3 which shows the understanding before this study). A further complication is the highly variable thickness of the package $(<20 \mathrm{~m}$ to $>300 \mathrm{~m})$, coupled with a complex deformation history, with eight recognised deformation events (Rowe et al., 2002). The orientation of the Mine Mafic Package varies widely thoughout the deposit; but in general dips $\sim 30^{\circ}$ to the north from its surface outcrop in the Main Pit (Figure 1.4).

The main style of Au mineralisation (Plutonic brown-lode; Vickery, 2004) typically occurs as thin ( 1-3 m wide) lodes that consist predominantly of quartz-biotiteamphibole-titanite-epidote-carbonate-tourmaline-arsenopyrite-pyrrhotite \pm chalcopyrite \pm scheelite $\pm \mathrm{Au}$. Where these Au-bearing zones are well developed, they tend to be near-parallel to the stratigraphy as marked by the rare metasedimentary horizons (Awan, 2000), and to the dominant foliation, which is also primarily parallel to metasediment horizons (Bagas, 1999). Examples of brown-lode-style mineralisation are presented in Figures 1.5 a,b,c,d. Previous workers at Plutonic 


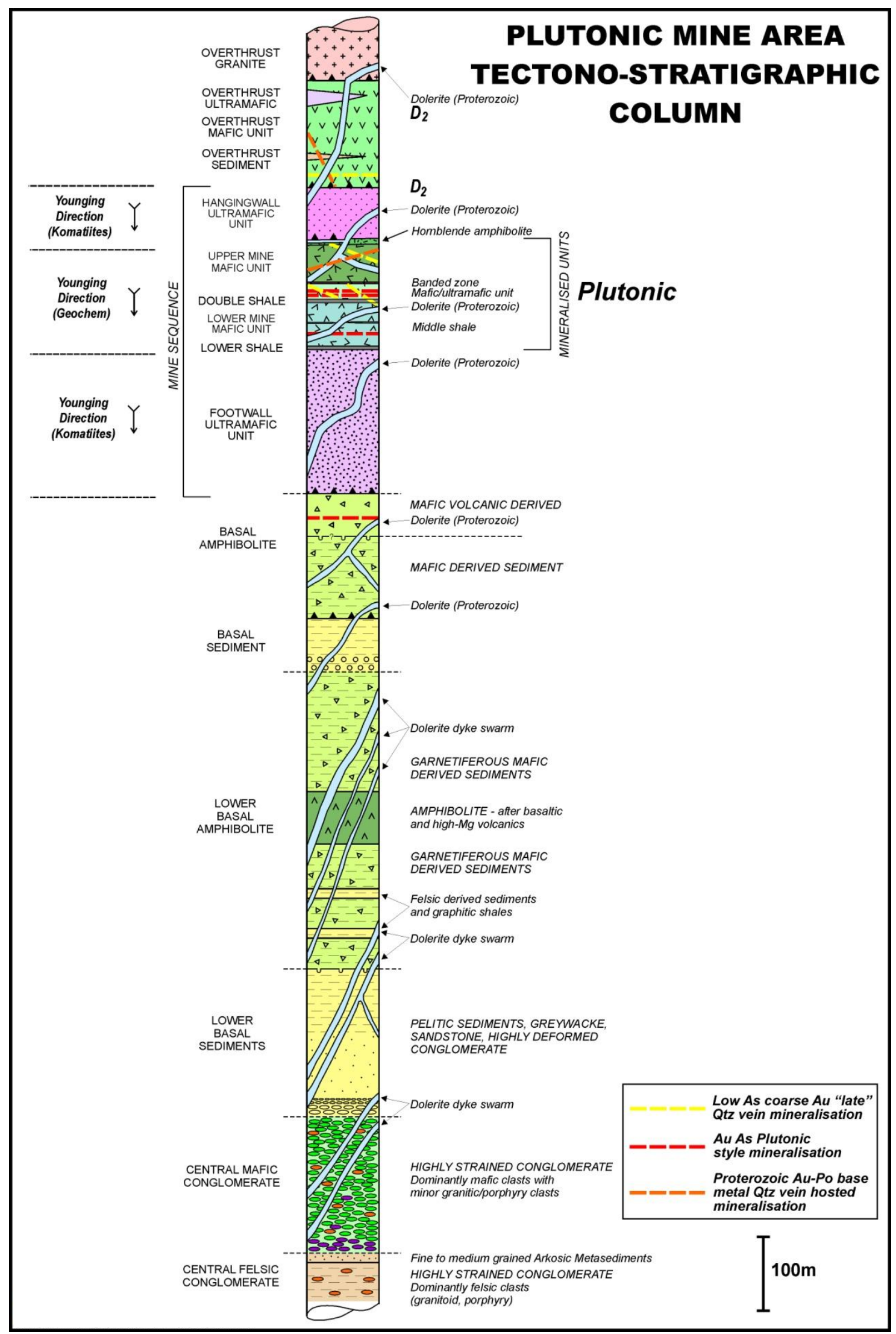

Figure 1.3 Simplified stratigraphic column for the greater Plutonic area, representing understanding at the start of this study, courtesy of Barrick (Australia Pacfic) Ltd. 


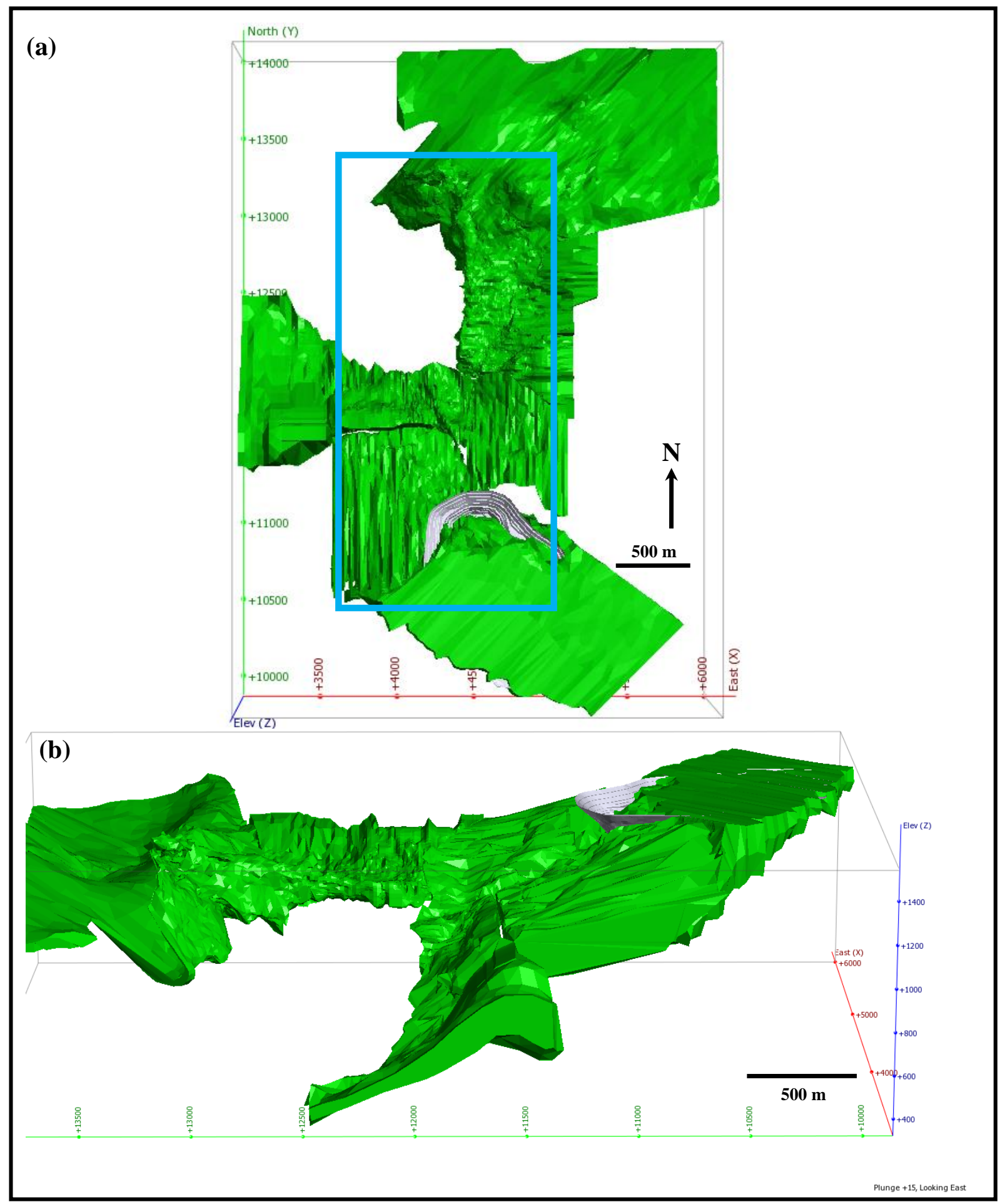

Figure 1.4 (a) Plan view of Plutonic from Leapfrog 3D $\mathrm{D}^{\mathrm{TM}}$ showing the Mine Mafic Package as a solid green wireframe. The main pit is represented by the grey wireframe. Mineralisation zone is defined by the blue oblong; all sample used in this study come from within this area. (b) Isometric view of the Mine Mafic Package from Leapfrog 3D ${ }^{\mathrm{TM}}$ looking towards the East, note the variation in thickness of the package from $<30 \mathrm{~m}$ to $>300 \mathrm{~m}$. The main pit is represented by the grey triangulation. 

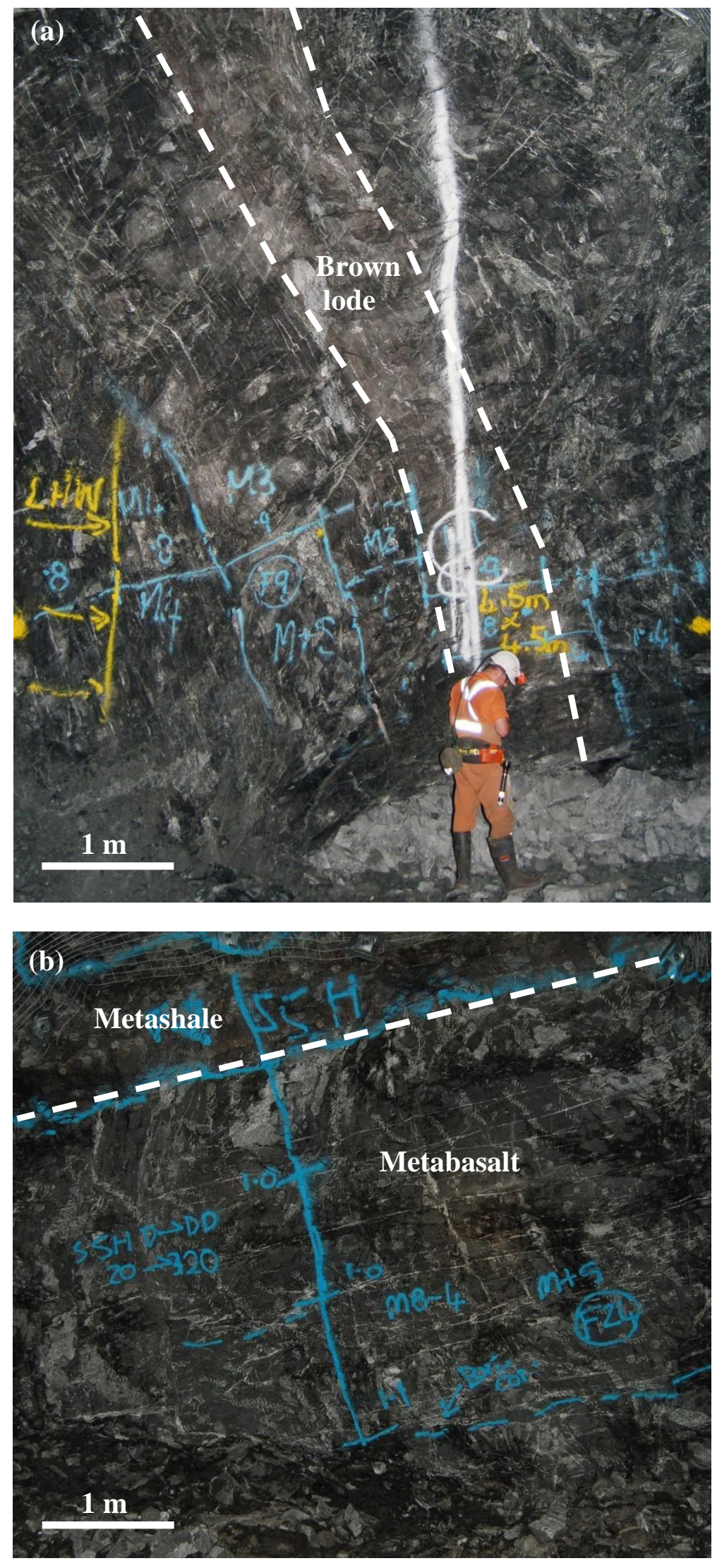

Figure 1.5 (a) Very high-grade brown-lode-style mineralisation in the BD3522NOD Face 9. (b)

Typical metabasalts in the MD2907EXC Face 24 with an intercalated metashale near the backs. 

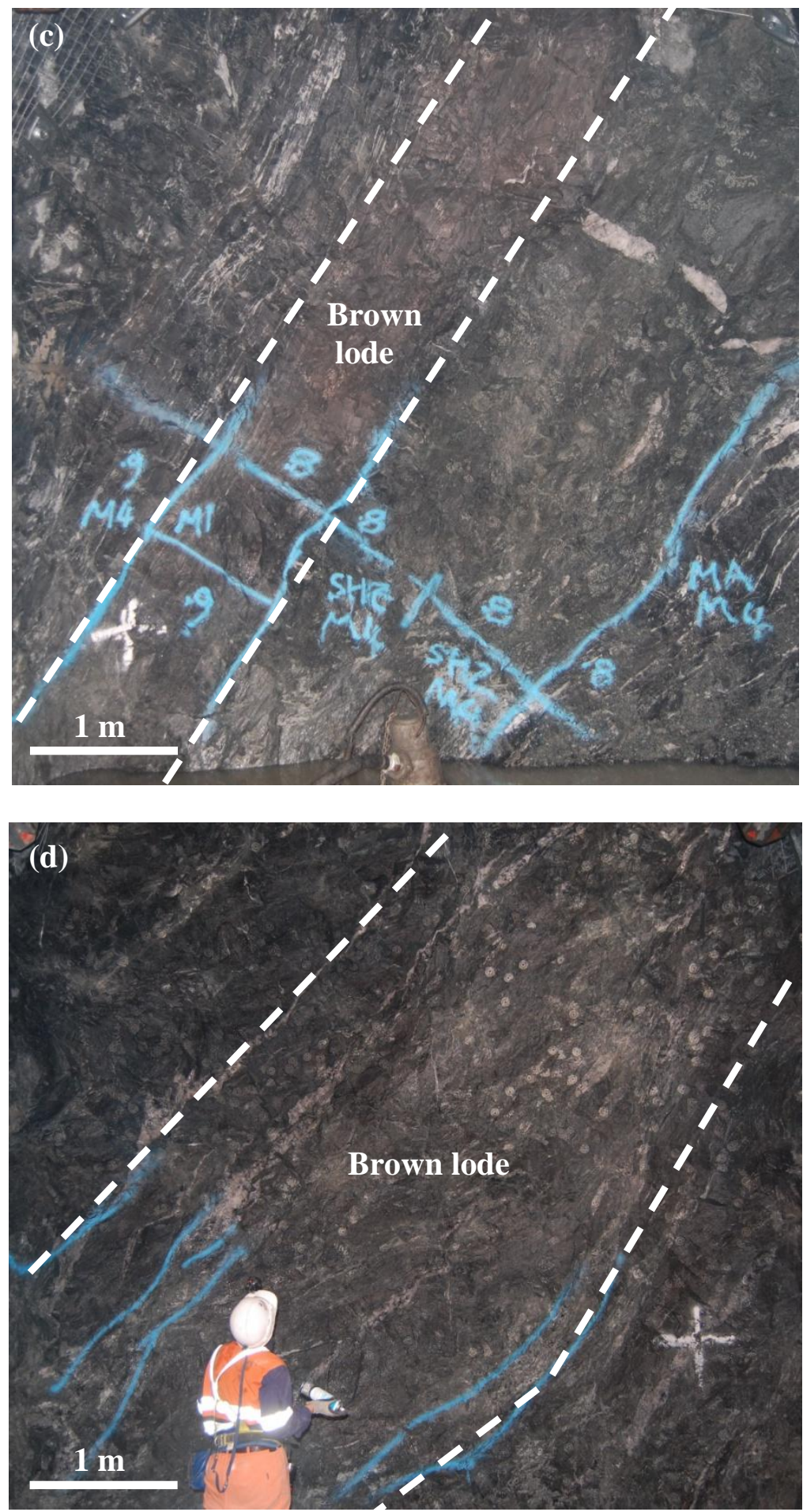

Figure 1.5 (c) Brown-lode style mineralisation in the ND2814EOD. (d) Brown-lode style mineralisation in the PD2211NXC Face 5. Note the very subtle colour change between the mineralisation and the unaltered wall rock around the lode. 
(Awan, 2000; Rowe et al., 2002; Vickery, 2004) considered the brown-lode-style mineralisation to be mylonite-hosted. However, petrographic and microstructural observations conducted during the present study suggest that stratigraphy was a dominant control on focusing Au-bearing fluids. Other less-common styles of $\mathrm{Au}$ mineralisation also occur at the Plutonic deposit. These include: sub-economic to marginally economic Au grades in apparently-unaltered metabasalt rock; shearcontrolled lodes that mineralogically resemble Plutonic brown lode but are hosted within structures (e.g. shears that cross-cut the foliation); and late-stage quartzcarbonate-pyrrhotite \pm chalcopyrite \pm Au veins. As is typical for deposits that have formed at relatively high temperature conditions (e.g. amphibolite facies), there is little evidence of the distinctive widespread zoned wallrock alteration halos and quartz veining that can help define where fluids were focused and Au was deposited at greenschist-facies conditions (Mikucki \& Ridley, 1993; Groves, 1993; Phillips et al., 1996; Groves et al., 1998).

\section{Previous work on Plutonic Gold Mine}

This summary represents all of the literature on Plutonic found during the course of this study. Despite being mined for over 20 years, little research has been done on the deposit, which results in little literature being available. A summary of the geological understanding of Plutonic at the start of this study is presented in Figure 1.6.

McMillan (1996), PhD by Noreen Vielreicher (née McMillan), University of Western Australia. Focussed on the Marymia Au deposits the north of the PWGB, namely K1, K2 and Triple P. Some limited samples were collected from Plutonic Gold Mine, mostly for geochronological work. This study concluded peak $P-T$ conditions were 


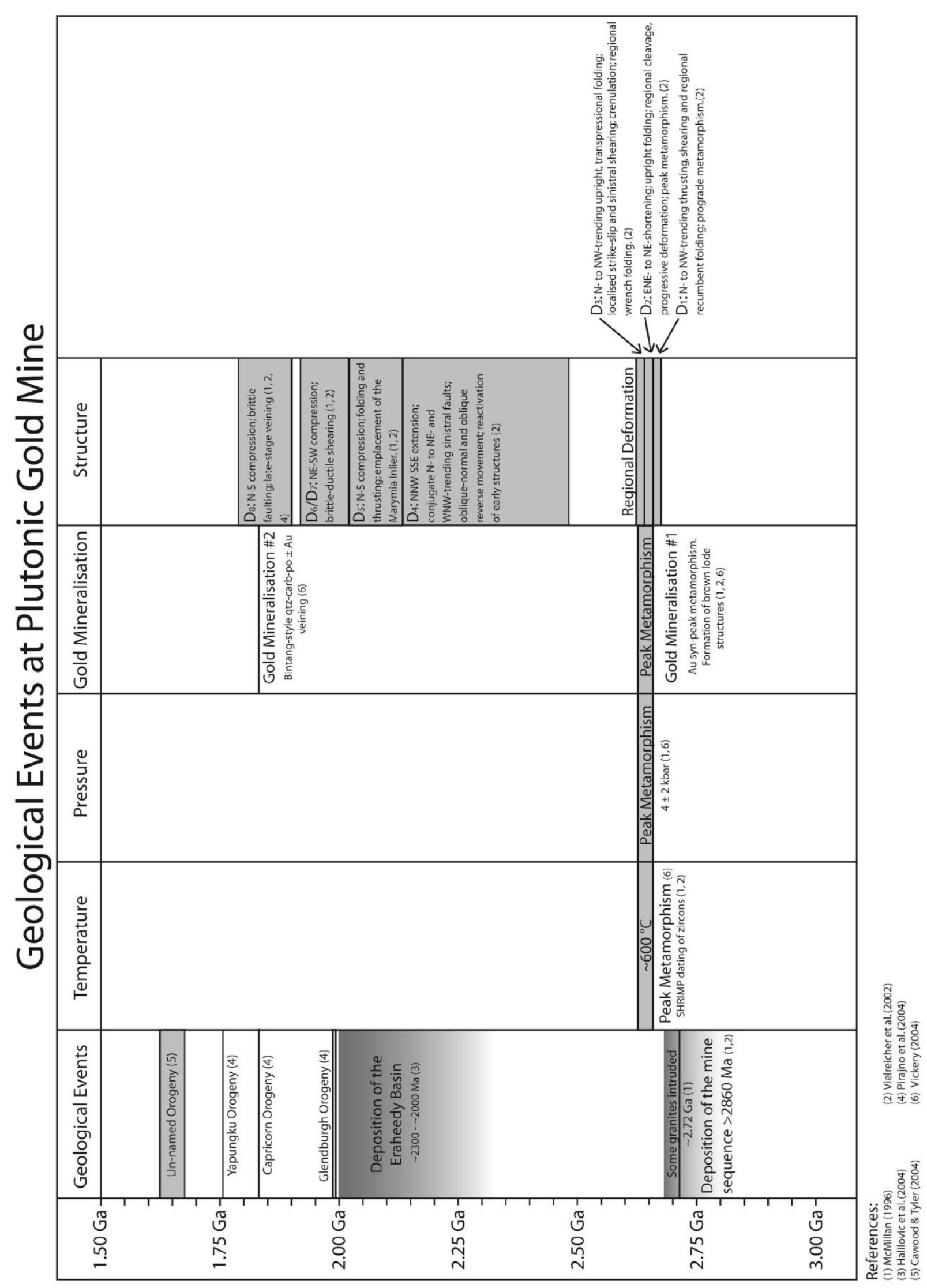

Figure 1.6 Summary diagram of geological events at Plutonic Gold Mine at the start of this study. 
$\sim 550{ }^{\circ} \mathrm{C}$ and $\sim 4$ kbar for the Marymia deposits based on traditional $P-T$ work. It provided age constraints on the intrusion of granites in the area at $2720 \mathrm{Ma}$, and peak metamorphism was at 2660-2630 Ma on the basis of U-Pb geochronology of zircons. The geochronology showed there were two generations of Au at Marymia, based on $\mathrm{Pb}$ isotopes model ages, at $\sim 2650 \mathrm{Ma}$ and a later event associated with the Capricorn Orogney 1830 Ma. Non-Au-bearing samples from Plutonic yielded ages of $2200 \mathrm{Ma}$; however, there was little discussion of the implications of this. A late stage hydrothermal event was dated in an overgrowth on a zircon at $1719 \pm 14 \mathrm{Ma}$.

Bagas (1999) published mapping in the Marymia Inlier by the Geological Survey of Western Australia in the late 1990s. It suggested that metamorphism in the PWGB was associated with horizontal tectonics with little or no crustal thickening. Also of note, was the assertion that much of the mineralisation at Plutonic Gold Mine was parallel to the dominant foliation.

Awan (2000), unpublished mine report, presents an indepth structural model for the deposit. It is largely summarised by Rowe et al. (2002) but has never been released by the company.

Vielreicher \& McNaughton (2002) published some of the results of McMillan (1996).

Vielreicher et al. (2002) published some of the results of McMillan (1996). 
Rowe et al. (2002), abstract of a presentation at the Applied Structural Geology for Mineral Exploration and Mining International Symposium. It summarised the understanding of the structural history of Plutonic at that time. It remains the only published synthesis of the structure of Plutonic.

Morgan (2004), honours thesis by Rebecca Morgan, Curtin University of Technology. It presented some whole rock analyses for the Mine Mafic Package in the Baltic resource area, but limited samples did not allow her to derive a stratigraphy for this area. She did some work looking at major and trace element plots for the types of basalts that comprise the Mine Mafic Package - the results of which are consistent with those presented herein.

Vickery (2004), PhD by Nancy Vickery, University of New Engalnd. It considered many aspects of the Plutonic deposit, including some geochronology and $P$ - $T$ work. However, sample selection and analytical irregularities in-so-far as can be determined for the areas relevant to this study, do not allow for a reasonable comparision of results between the two studies.

\section{Thesis Structure}

The basic structure of this thesis is in the form of three papers that examine three key geological aspects of Plutonic Gold Mine: host rock geochemical stratigraphy (Chapter 2); metamorphism (Chapter 3); timing constraints on Au mineralisation, metasomatism and cooling post-peak metamorphism (Chapter 4). Each of those chapters is formatted appropriately for the journal they have been submitted to: Journal of Geochemical Exploration; Journal of Metamorphic Geology; and 
Mineralium Deposita respectively, except for figure and table numbers which include a reference to the chapter. The introduction and conclusion in each chapter pertains only to that chapter. References for each paper are found at the end of each chapter to ensure there is no ambiguity between references such as Gazley et al. (2011a) and Gazley et al. (2011b) with a complete reference list presented at the end of this thesis. Chapter 2 has been published by Journal of Geochemical Exploration (vol 110, no.26, pp.74-80), and was reviewed by K. Howard Poulsen, Rob Kerrich, Steve Barnes, and two anonymous reviewers; Chapter 3 has been published Journal of Metamorphic Geology (vol 29, no. 6, pp. 685-697), and was reviewed by Katy Evans, Johann Diener and Richard White; Chapter 4 is in review at Mineralium Deposita.

The author acknowledges that copyright of published works contained within this thesis resides with the copyright holder(s) of those works.

\section{Statement of authorship}

This thesis is my own original work, and the co-authorship of the publications resulting out of this research is an acknowledgement of academic advice, and assistance both financial and logistical, from those persons concerned. Statements of authorship for each individual paper follow below. 
Gazley, M.F., Vry, J.K., du Plessis, E., Handler, M.R., 2011. Application of hand-held $\underline{\text { X-ray fluorescence analyses to Metabasalt Stratigraphy, Plutonic Gold Mine, Western }}$ Australia. Journal of Geochemical Exploration, vol 110, no.26, pp.74-80, doi: 10.1016/j.explo.2011.03.002.

Michael Gazley conceived the idea, evolved the method for reliable pXRF analyses, conducted the analyses, logged the core, drafted the figures and was responsible for writing the paper.

Julie Vry provided advice and criticism of the process and of the results as well as significant editorial advice - especially with regards to replying to reviewers.

Ettienne du Plessis proposed that a stratigraphy needed to be resolved for the Mine Mafic Package, and provided financial and logistical support to the project. He encouraged discussions on the results, and offered some editorial advice.

Monica Handler provided insights into igneous systems, assisted with treatment of the geochemical data, and offered some editorial advice.

Gazley, M.F., Vry, J.K., Boorman, J.C., 2011. P-T evolution in greenstone belt mafic amphibolites: an example from Plutonic Gold Mine, Marymia Inlier, Western Australia. Journal of Metamorphic Geology, vol 29, no. 6, pp. 685-697, doi: $10.1111 / \mathrm{j} .1525-1314.2011 .00936 . \mathrm{x}$

Michael Gazley was responsible for producing the THERMOCALC pseudosections, selecting and analysing samples on the electron microprobe, building a spreadsheet to 
calculate hornblende-plagioclase barometry, was primarily responsible for producing the figures, and was responsible for writing the paper.

Julie Vry showed the first author how to produce THERMOCALC diagrams and how to do the chemical calculations required for this paper. She provided advice and criticism throughout the process and of results, as well as significant editorial advice especially with regards to replying to reviewers.

James Boorman assisted the first author with computer modelling with THERMOCALC (especially with respect to data inputs to the software) and the production of some of the figures. He also offered some editorial advice.

Gazley, M.F., Vry, J.K, Millet, M.-A., Handler, M.R., du Plessis, E., Baker, J.A., in submission. New timing constraints on Archean-Proterozoic gold mineralization, $\underline{\text { metamorphism, and metasomatism at Plutonic Gold Mine, Marymia Inlier, Western }}$ Australia. Mineralium Deposita.

Michael Gazley conducted the analyses under the supervision of, and with assistance from, Marc-Alban Millet, Monica Handler, and Joel Baker, and was responsible for writing the paper and producing the figures.

Julie Vry provided advice and criticism of results, as well as significant editorial advice.

Marc-Alban Millet taught the first author how to conduct geochronological analyses and how to process data to produce ages. He also offered some editorial advice. 
Monica Handler taught the first author how to conduct geochronological analyses and reduce data to produce ages. She also offered some editorial advice.

Ettienne du Plessis provided financial and logistical support to the project. He also encouraged discussions of the results, and offered some editorial advice.

Joel Baker taught the first author how to conduct geochronological analyses and reduce data to produce ages. 


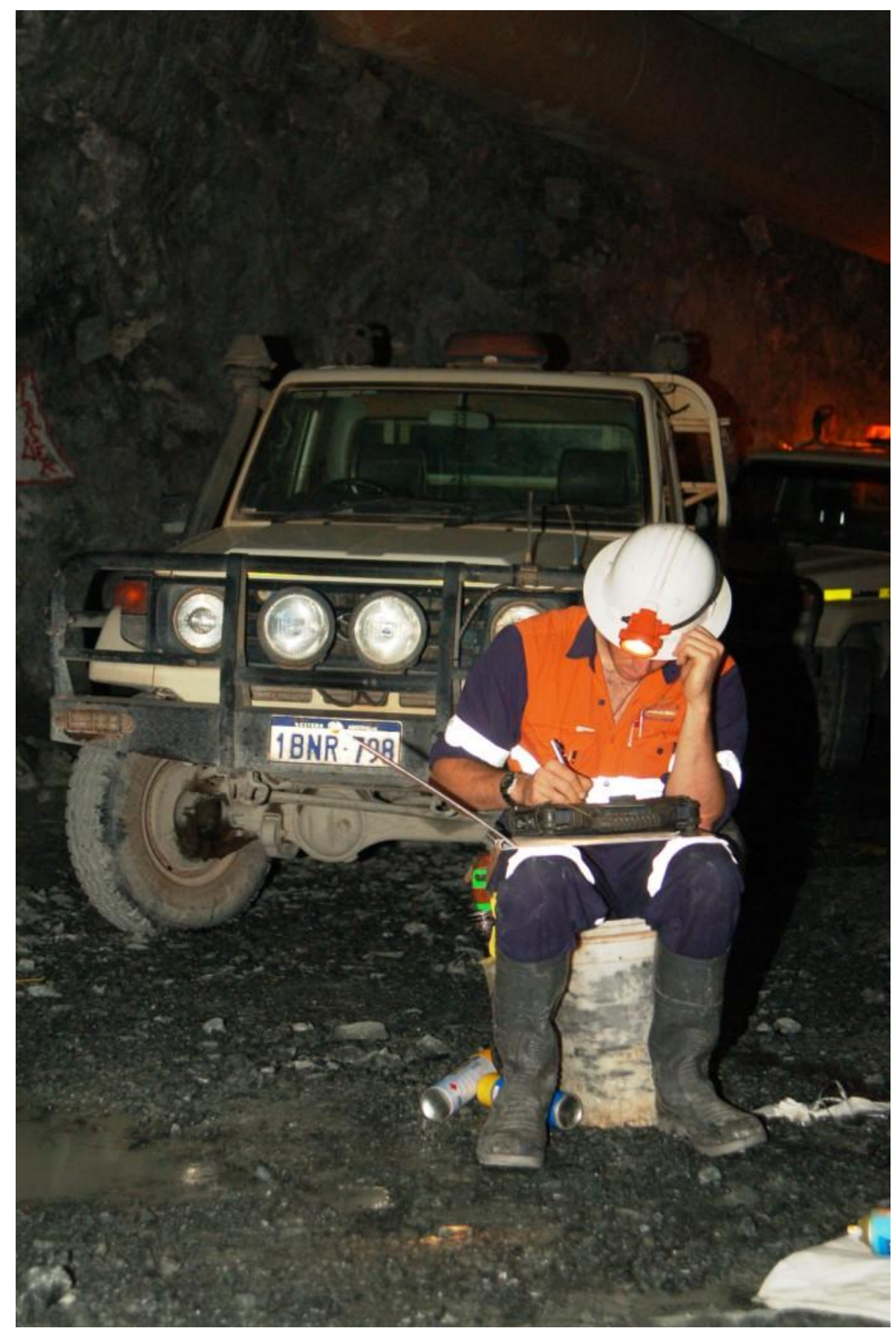

Ryan mapping underground. 


\title{
CHAPTER 2
}

\section{APPLICATION OF PORTABLE X-RAY FLUORESCENCE ANALYSES TO METABASALT STRATIGRAPHY, PLUTONIC GOLD MINE, WESTERN AUSTRALIA ${ }^{1}$}

\begin{abstract}
Stratigraphy, structure and host-rock chemistry are dominant controls on the location of $\mathrm{Au}$ in Archaean greenstone-hosted Au deposits, but the stratigraphy in such deposits is seldom obvious due to the monotonous nature of the host rocks or pervasive alteration associated with Au mineralisation. Portable, hand-held, X-ray fluorescence (pXRF) spectrometry provides a method to rapidly collect large amounts of whole-rock geochemical data that can yield new insights into both stratigraphy and $\mathrm{Au}$ localisation. Here we present results of $\mathrm{pXRF}$ analyses of samples from a representative section through Au-mineralised amphibolite-facies metabasaltic rocks at Plutonic Gold Mine, Western Australia. These data illustrate a geochemical stratigraphy in which individual lava flows can be identified on the basis of element concentrations. The most evolved basalts are at the structural base of the succession, and the least evolved at the top of the sequence, confirming previous geochemical interpretations and textural evidence that the sequence is overturned, and demonstrating for the first time that the presented section does not involve significant structural repetition. In conjunction with Au assay data, the pXRF data reveal that $\mathrm{Au}$ commonly occurs along basalt flow boundaries. The elemental concentration data clearly demonstrates for the first time the stratigraphic control on Au mineralisation that is not readily apparent at the macroscopic level. The methods described in this paper are readily applied, and have the potential to enhance the understanding of
\end{abstract}

\footnotetext{
${ }^{1}$ This chapter is formatted for, and published in Journal of Geochemical Exploration, vol. 110, no.26, pp.74-80, after reviews from K. Howard Poulsen, Rob Kerrich, Steve Barnes, and two anonymous reviewers.
} 
otherwise unclear stratigraphy and its control on mineralisation in many different types of deposits worldwide.

Keywords: geochemical stratigraphy, stratigraphic controls on gold mineralisation, metabasalt, Plutonic Gold Mine, Archaean greenstone-hosted gold.

\section{INTRODUCTION}

Archaean greenstone belts host an abundance of Au deposits (Phillips, 1986; Phillips and Gibb, 1993; Groves et al., 2003) that formed in response to stratigraphic and structural controls on the flow of Au-bearing fluid through greenstone rocks. In such deposits, the original stratigraphy and its possible role in localising Au mineralisation can be difficult to discern due to a lack of distinctive marker units, the mineralogically and texturally monotonous nature of the metabasaltic host rocks, and the combined effects of metamorphism, deformation, and alteration associated with mineralisation.

Geochemistry can be a useful tool to better understand the geochemical architecture of deposits, especially where the original stratigraphy can be difficult to discern. pXRF methods allow large numbers of samples to be analysed rapidly for selected elements. In this paper, we show that results of pXRF analyses for elements such as $\mathrm{Cr}, \mathrm{Zr}, \mathrm{Ti}$, and $\mathrm{K}$ can be used together with independently-obtained $\mathrm{Au}$ assay data to provide new insights into both the stratigraphy of metabasalt successions and the localisation of Au within metabasalt stratigraphies. 


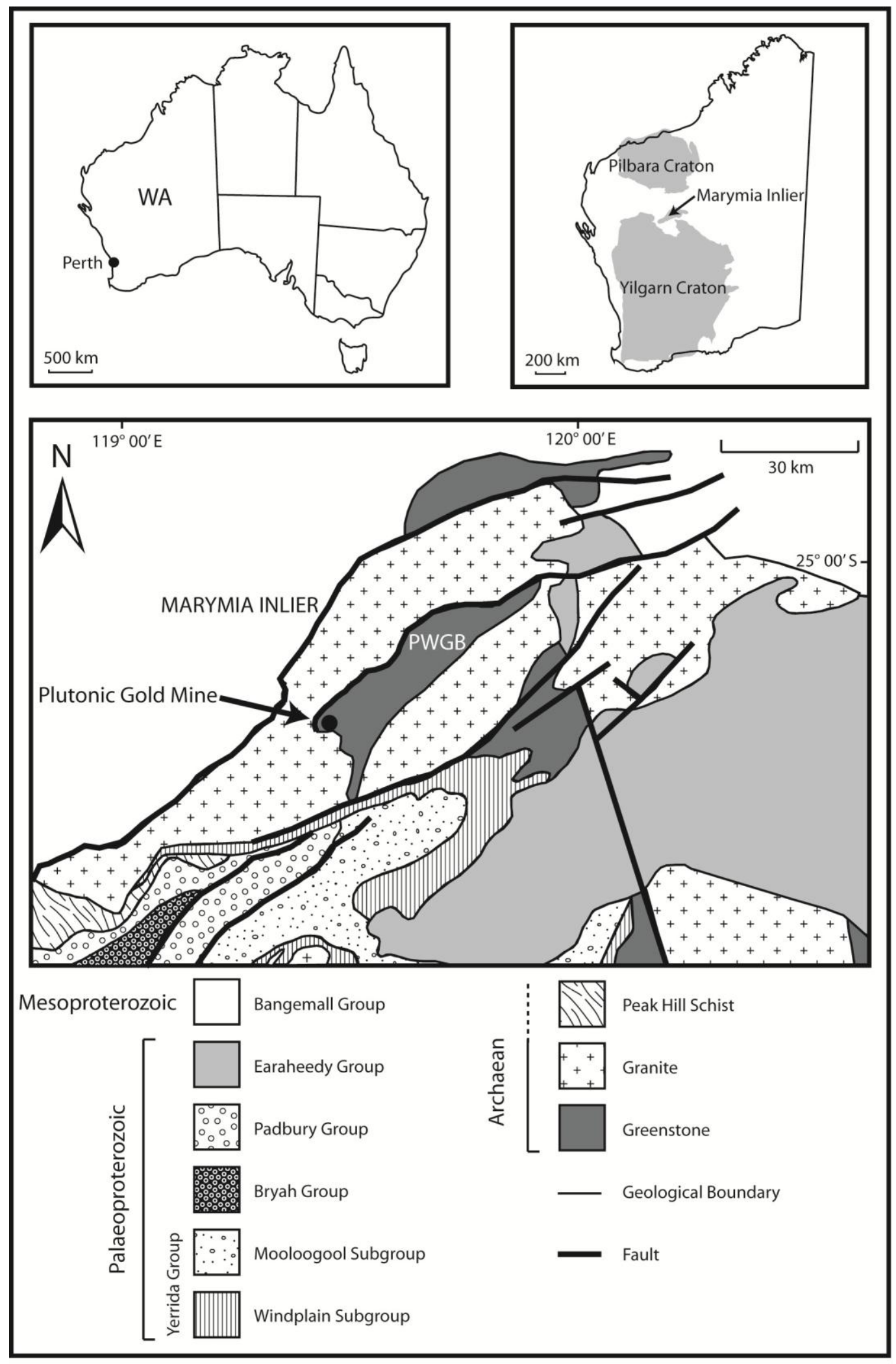

Figure 2.1 Simplified location and geological map for Plutonic Gold Mine, modified after Tyler and Hocking (2002). PWGB = Plutonic Well Greenstone Belt. 


\section{GEOLOGICAL SETTING}

Plutonic Gold Mine (Plutonic) is an underground mine located approximately $800 \mathrm{~km}$ north-east of Perth, Western Australia, at the southern end of the Plutonic Well Greenstone Belt in the Marymia Inlier between the Yilgarn and Pilbara cratons (Figure 2.1). In 20 years of production, over four million oz of Au have been produced from Plutonic, and the deposit has a total Au endowment of $\sim 10.5$ million ounces (Fallon et al., 2010).

Based on U-Pb dating of zircons in cross-cutting intrusive units, rocks in the Plutonic Well Greenstone Belt were deposited before 2.68 Ga and metamorphosed to amphibolite facies conditions at 2.66 - 2.63 Ga (McMillan, 1996; Bagas, 1999; Vielreicher et al., 2002; Vickery, 2004). Peak metamorphic conditions were $\geq 8 \pm 2$ kbar and $\sim 600 \pm 50^{\circ} \mathrm{C}$ based on results of both traditional geothermobarometry and forward modelling using THERMOCALC, and led to the formation of hornblendeplagioclase-titanite-quartz \pm epidote assemblages in the mafic rocks (Gazley et al., 2011 (Chapter 3)). Relict ilmenite and actinolite can be preserved in titanite and hornblende respectively, and variable amounts of chlorite and epidote formed during retrogression and/or later metamorphic events.

The early history of the Plutonic area is comparable to that of greenstone sequences in the Yilgarn Craton, and later features are attributable to suturing events during the Paleoproterozoic Capricorn Orogeny that brought together the Pilbara and Yilgarn cratons to form the West Australian Craton at 1.83 Ga (Vielreicher et al., 2002; Cawood and Tyler, 2004; Pirajno et al., 2004). The major Au mineralisation event occurred in the north of the belt at $\sim 2.65 \mathrm{Ga}$, and possibly later at $\sim 2.20 \mathrm{Ga}$ at the 
southern (Plutonic) end of the belt, based on results of Pb-isotope model ages of sulphide minerals (McMillan, 1996; Vielreicher et al., 2002; Gazley et al., in submission (Chapter 4)). The early Au mineralisation event was followed by two later Au mineralising events, one at $\sim 1.83 \mathrm{Ga}$, in the Capricorn Orogeny (Vickery, 2004; Pirajno et al., 2004; Gazley et al., in submission (Chapter 4)), and a later one at $\sim 1.72$ $\mathrm{Ga}$, probably syn- or post- a hydrothermal event, that deposited base-metal associated $\mathrm{Au}$ (Vielreicher et al., 2002; Gazley et al., in submission (Chapter 4)).

Gold at Plutonic is for the most part hosted in the Mine Mafic Package. Morgan (2004) used conventional XRF analyses to show that in the present study area this package consists predominantly of high $\mathrm{Fe}$ - to high $\mathrm{Mg}$-tholeiitic rocks ${ }^{2}$. Vickery (2004) determined that the Mine Mafic Package in an area to the south of the present study area is also tholeiitic in composition, on the basis of conventional XRF results, with the Lower Mine Mafic Package comprised of high-K tholeiite. Pillow structures (Figure 2.2a), which are commonly preserved in the Mine Mafic Package, especially in low-strain areas, show that deposition occurred in a subaqueous environment.

Minor, thin (typically $<1 \mathrm{~m}$ ), discontinuous units within the metabasalt sequence include the metamorphosed equivalents of silica- and sulphide-rich sediments and precursors that are interpreted as sediments with relatively mafic bulk compositions. These minor rock types can be interlayered on a cm- to dm-scale (e.g. Figure 2.2b). Based on results of detailed core-logging conducted during the present study, the uppermost and lowermost parts of the Mine Mafic Package (the uppermost $\sim 20 \mathrm{~m}$ and the lowermost $\sim 30 \mathrm{~m}$ in the section presented in this paper) contain most of these

\footnotetext{
${ }^{2}$ Tertiary and bivariate discrimination diagrams after Morgan (2004) are presented in Appendix 2.
} 
metasedimentary layers, with the middle section comprised almost solely of metabasalt.

Prior to this study, only a general stratigraphy of the Mine Mafic Package had been reported (Vickery et al., 1998; Rowe et al., 2002). This was largely based on the stratigraphy exposed in the Main Pit where the Mine Mafic Package is divided into two sections separated by two graphitic metashales that are typically within $\sim 5 \mathrm{~m}$ of each other (the Double Shale, see Figure 2.3a). A Lower Shale was also recognised near, or adjacent to, the Footwall Ultramafic.

A detailed stratigraphy had proven difficult to resolve as there are very few distinct and continuous marker horizons, either from drill hole to drill hole or within the underground development. Visual recognition of flow unit boundaries in diamond drill core can be difficult, and is based on recognition of subtle features such as pillow margins or amygdules, or slight changes in mineralogy, such as a change in the abundance of ilmenite and/or titanite at a hand-sample scale. A further complication is the highly variable thickness of the Mine Mafic Package $(<20 \mathrm{~m}$ to $>300 \mathrm{~m})$ coupled with a complex deformation history, with eight recognised deformation events (Rowe et al., 2002).

The main style of Au mineralisation (Plutonic brown lode; Vickery, 2004) typically occurs as thin $(\sim 1-3 \mathrm{~m}$ wide) lodes that consist predominantly of quartz-biotiteamphibole-titanite-epidote-carbonate-tourmaline-arsenopyrite-pyrrhotite \pm chalcopyrite \pm scheelite $\pm \mathrm{Au}$. Where these Au-bearing zones are well developed, they tend to be near-parallel to the stratigraphy as marked by the rare metasedimentary 
(a)

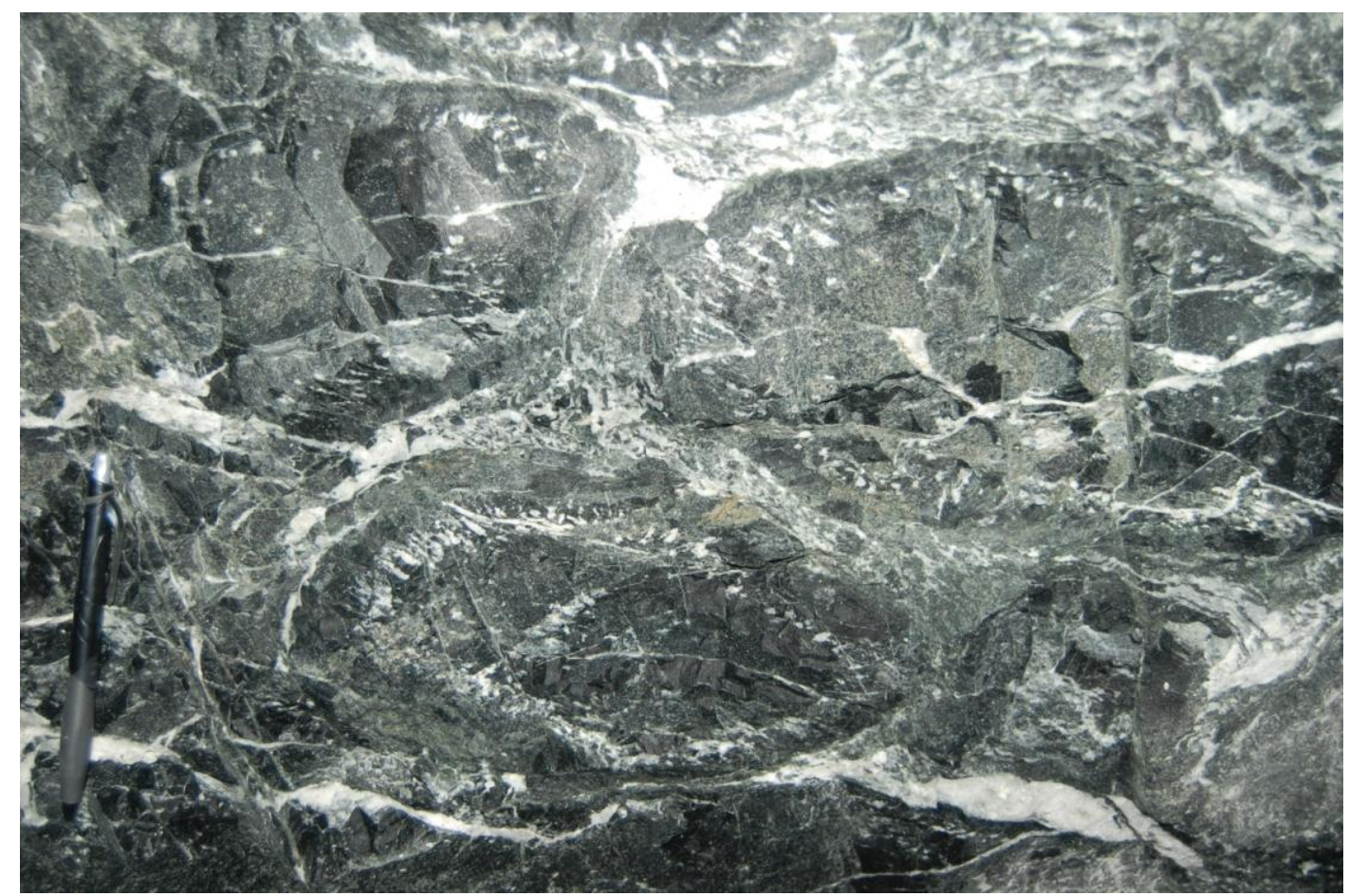

(b)
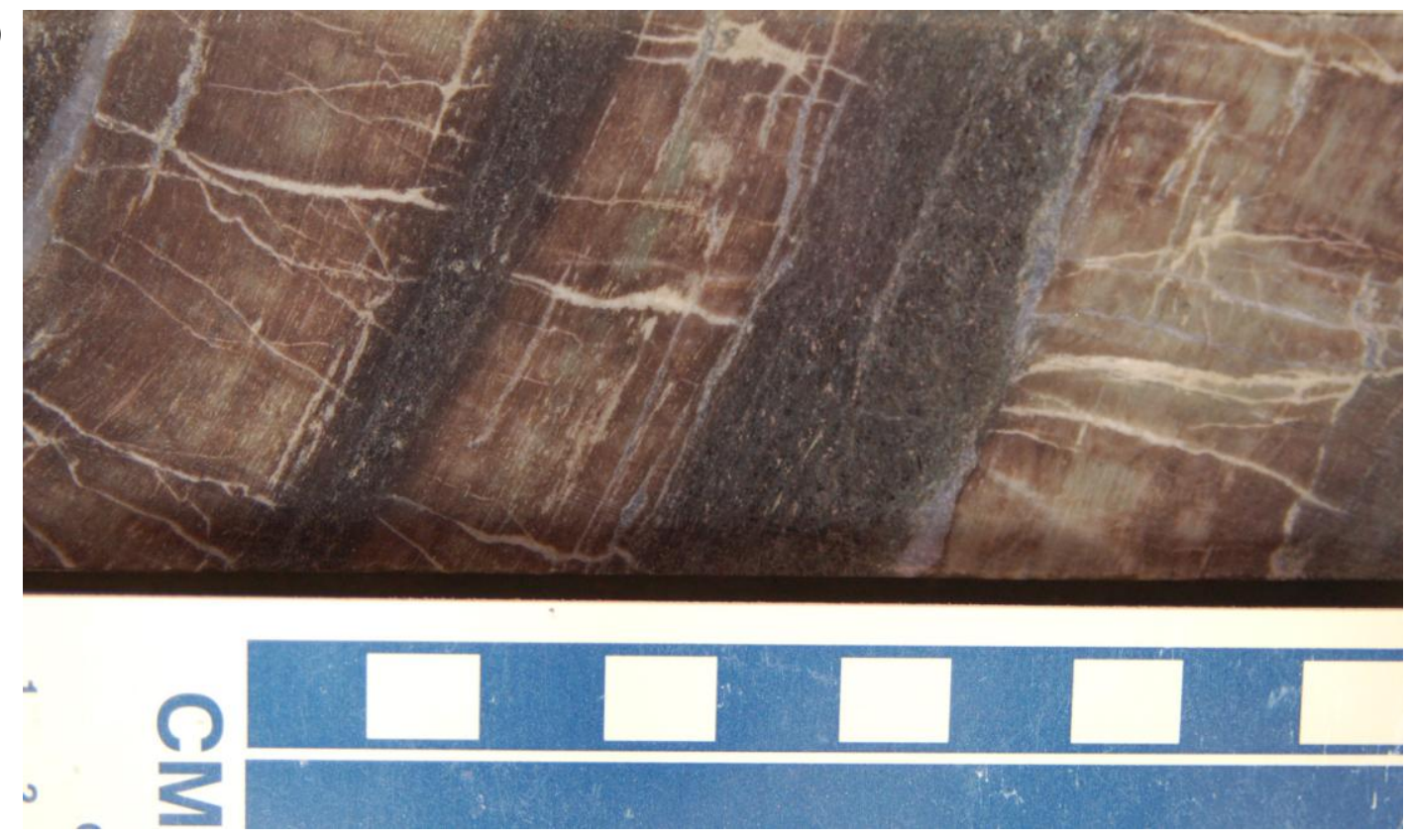

Figure 2.2 (a) An example of a metabasalt with pillow textures intact with amygdules and associated quartz-carbonate veining from the BD 3458 SXC. Note fine grained nature of the metabasalt postmetamorphism. Pen for scale. (b) Minor rock types, probably derived from interbedded cherty and relatively mafic metasediments. 

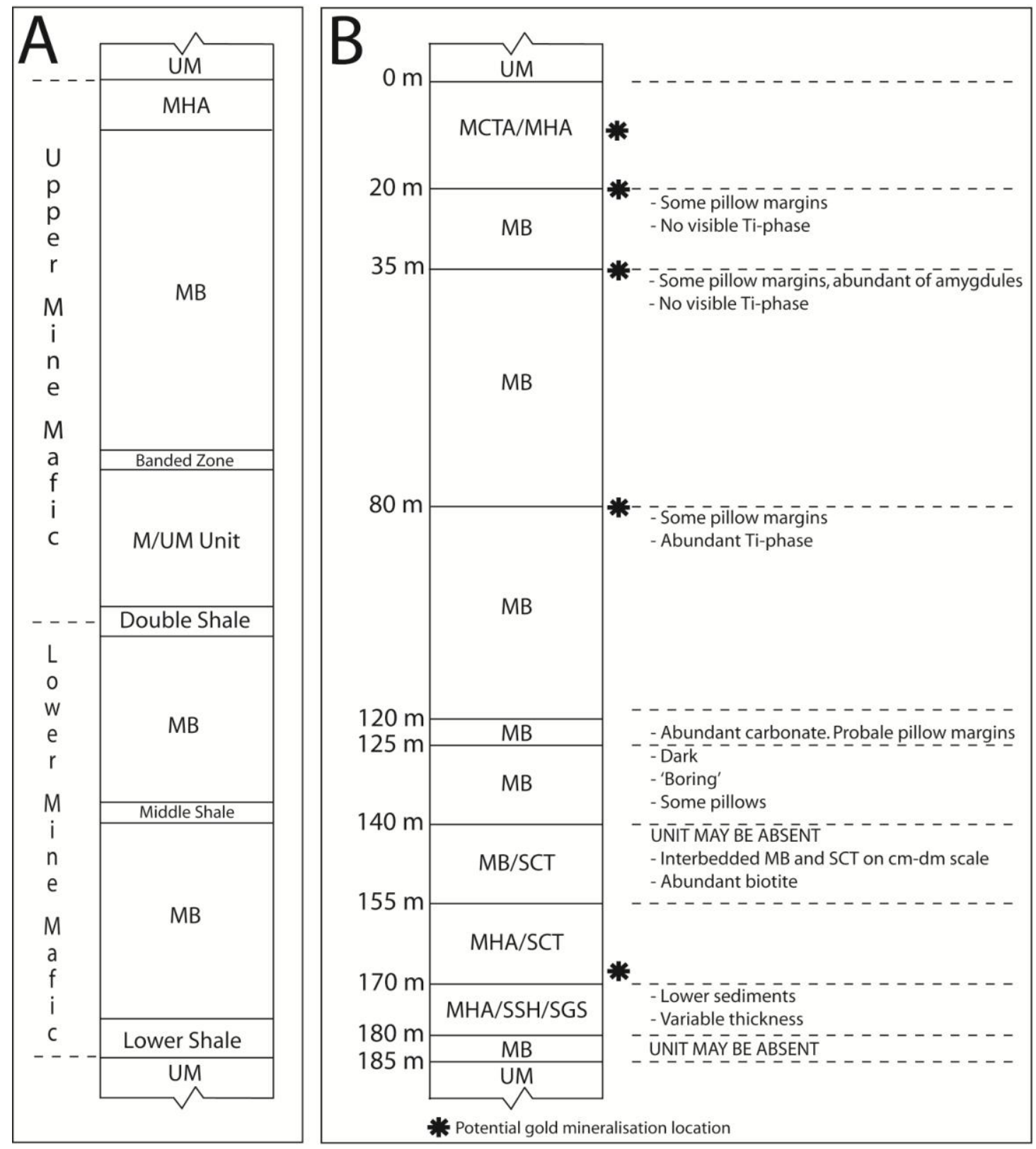

Figure 2.3 (a) Previous non-measured stratigraphic section for the Mine Mafic Package modified after Vickery et al. (1998). (b) The measured, representative section of the Mine Mafic Package for the diamond drill holes with unit boundaries identified from the changes in rock chemistry identified with systematic pXRF analyses. The Double Shale is notably absent in (b) as its appearance is sporadic in the down-dip areas of the deposit, further away from the Main Pit environment on which the section presented in (a) was compiled. Re-interpretation of Vickery's (2004) geochemical data suggests the Double Shale would be located at $\sim 155 \mathrm{~m}$ in this section. The Middle Shale is most probably not represented in our section; while the Lower Shale is represented by the MHA/SSH/SGS unit at 170 $180 \mathrm{~m}$. For both panels: $\mathrm{M}=$ mafic, $\mathrm{UM}=$ ultramafic, $\mathrm{MB}=$ metabasalt, $\mathrm{MCTA}=$ mafic chlorite tremolite amphibolite, $\mathrm{MHA}=$ mafic hornblende amphibolite, $\mathrm{MB}=$ metabasalt, $\mathrm{SCT}=$ metachert, $\mathrm{SGS}=$ graphitic metashale, $\mathrm{SSH}=$ metashale. 
horizons (Awan, 2000), and to the dominant foliation, which is predominantly parallel to metasediment horizons (Bagas, 1999). Previous workers at Plutonic (Awan, 2000; Rowe et al., 2002; Vickery, 2004) considered the brown-lode-style mineralisation to be mylonite-hosted. However, petrographic and microstructural observations conducted in conjunction with the present study suggest a metasedimentary origin for brown lode, with later fluid flow depositing Au within these sequences. Other less common styles of $\mathrm{Au}$ mineralisation also occur at the Plutonic deposit. These include: sub-economic to marginally economic Au grades in apparently unaltered metabasalt rock; shear-controlled lodes that mineralogically resembles Plutonic brown lode but are hosted within structures (e.g. shears that crosscut the foliation); and late-stage quartz-carbonate-pyrrhotite \pm chalcopyrite $\pm \mathrm{Au}$ veins. As is typical for deposits that have formed at relatively high temperature conditions (e.g. amphibolite facies) there is little evidence of the distinctive widespread zoned wallrock alteration halos and quartz veining that can help define where fluids were focused and Au was deposited at greenschist-facies conditions (Mikucki and Ridley, 1993; Groves, 1993; Phillips et al., 1996; Groves et al., 1998).

The near-parallelism of the early brown lode to sedimentary units, both at Plutonic and elsewhere in the Marymia Inlier (Bagas, 1999), suggest that the original stratigraphy may have been a primary control on the localisation of Au deposition during this early event. A more detailed understanding of the stratigraphy is thus critically important for understanding Au mineralisation in the Mine Mafic Package. 


\section{METHODS}

In this paper we present results for selected elements detected by pXRF in two diamond drill cores (UDD8334 and UDD8337), which were drilled close to perpendicular to the Mine Mafic Package. The two holes were drilled in opposite directions from a drill drive, and together provide a complete $184 \mathrm{~m}$ thick section through the entire Mine Mafic Package, with a gap of $5 \mathrm{~m}$ in the data at the site of the join. Gold concentrations from the same sections of the drill core were determined by fire assay at Ultra Trace Laboratories, Perth, Western Australia.

New geochemical results obtained as a part of this study and results of detailed logging of numerous diamond drill cores show that the section described in this paper is representative of at least the central third of the Mine Mafic Package within the current workings at Plutonic. To the north of the study area, the package thins and becomes dominated by more coarse amphibolite and metasediments, while to the south of the study area, the stratigraphic column derived from mapping in the pit environment of Vickery et al. (1998) is perhaps more applicable (Figure 2.3a). The stratigraphic section presented here (Figure 2.3b), is derived from geochemical data that was gathered from one section through the Mine Mafic Package, and is consistent with five other complete or near-complete geochemical sections of the true thickness of the Mine Mafic Package from the same area. In addition, the data presented are supported by evidence obtained from relogging of drill core from numerous older diamond drill holes that made both partial and complete sections of the Mine Mafic Package. 
The element concentration data presented here were obtained by whole rock XRF using an Innov-X Omega pXRF with a $10-40 \mathrm{kV}(10-50 \mu \mathrm{A}) \mathrm{X}$-ray tube. The Innov-X Omega $\mathrm{pXRF}$ is not capable of detecting elements with atomic numbers less than fifteen (including $\mathrm{Mg}, \mathrm{Al}$ or $\mathrm{Si}$ ), so although the method described here is readily applied and rapid, it is not suitable for collecting some element ratio data traditionally used in studies of magma evolution. Prior to pXRF analysis, samples representing lengths of diamond drill core ranging from $0.3-1.0 \mathrm{~m}$ were prepared by grinding to a fineness at which $>70 \%$ passed through a $212 \mu \mathrm{m}$ sieve, and collected in paper bags. Analyses were conducted through the paper bags. A check for possible analytical interferences from any fillers and pigments used in making the paper bags was done by separately analysing a $1 \mathrm{~cm}$ thick stack of the same paper bags. In this test, only $\mathrm{Ca}$ was detected at levels other than just over the lower limit of determination, so wholerock analytical results for $\mathrm{Ca}$ were not used in the present study. The $\mathrm{K}, \mathrm{Cr}$, $\mathrm{Ti}$, and $\mathrm{Zr}$ concentrations in the analysed whole-rock samples were typically an order of magnitude greater than their lower limits of determination, so for these elements any interference from the paper bags can be considered negligible. The lower limit of determination for each element was statistically derived from the analysis of 21 replicates of a standard of an appropriate concentration following the recommendations of MacDougall and Crummett (1980). Typical concentrations and lower limits of determination are listed in Table 2.1. The methods for $\mathrm{pXRF}$ analyses applied in this study were arrived at independently to, but compare well with those suggested by Morris (2009). For a complete discussion of techniques and issues surrounding analyses by pXRF see Morris (2009). ${ }^{3}$

\footnotetext{
${ }^{3}$ A graphic representation of the pXRF workflow used in this study is presented in Appendix 3.
} 


\section{Table 2.1}

Lower limit of determination for elements by statistical analysis of 21 replicates of an appropriate concentration standard following the recommendations of MacDougall and Crummett (1980). Concentrations in ppm.

\begin{tabular}{cccccc}
\hline Element & $\begin{array}{c}\text { Expected } \\
\text { Value }\end{array}$ & $\begin{array}{c}\text { Median } \\
\text { Value }\end{array}$ & $\begin{array}{c}\text { Standard } \\
\text { Deviation }\end{array}$ & $\begin{array}{c}\text { Lower Limit of } \\
\text { Determination }\end{array}$ & $\begin{array}{c}\text { Metabasalt } \\
\text { Concentrations }\end{array}$ \\
\hline $\mathrm{K}$ & 4535 & 3749 & 328 & 830 & $1,500-5,000$ \\
$\mathrm{Ti}$ & 8033 & 8968 & 264 & 668 & $2,000-6,000$ \\
$\mathrm{Cr}$ & 142 & 203 & 35 & 90 & $100-1,300$ \\
$\mathrm{Zr}$ & 32 & 65 & 3 & 8 & $45-105$ \\
\hline
\end{tabular}

The pXRF was calibrated at the start of each sample run to international basalt standard JB-1 (Ando et al., 1989), using the same analytical procedures for the standard as for the samples (e.g. analysed through the same paper bags that contained the unknown samples). The analytical uncertainty on each analysis is a function of run-time; a 90 s run-time was selected to optimise the number of samples that could be analysed in a reasonable time. Analytical uncertainties are on the order of $\pm 10 \%$ as reported by the pXRF unit; this error may be decreased by increasing the analysis time without substantively altering the concentration determined.

Analyses performed through paper bags underestimate element concentrations as the paper absorbs some of the X-rays emitted. Elements with lower atomic numbers (e.g. K) are more seriously affected by this attenuation, with concentrations up to $50 \%$ lower than the expected value returned for analyses of standards. Results from analyses of the standard analyses were used to correct for this, and the standard was periodically reanalysed, approximately every 15 samples, to check for analytical drift during the run. Traditional XRF data for four selected samples were obtained as an independent analytical cross-check and are shown as large stars on Figure 2.4. For 
these cross-checks, one sample was selected from each of the obvious plateaux in $\mathrm{Cr}$ concentration shown on Figure 2.4. These analyses were performed by Ultra Trace Laboratories, Perth, Western Australia, on borate glass discs using a Panalytical XRF instrument. Volatiles were measured by robotic thermogravimetric analysis. These results and their corresponding pXRF analysis are presented in Table 2.2.

It is possible to collect data by analysing diamond drill core directly. This requires less correction than analyses of pulverised samples in paper bags, but is much more sensitive to the effects of local veining, small-scale alteration, compositional banding, or variations in grain size, due to the small analytical spot sized used by the Innov-X pXRF (approximately $5 \mathrm{~mm}$ ). For this reason, we consider it better to homogenise a larger sample (e.g. $0.3-1.0 \mathrm{~m}$ of core, as any lithology of interest is seldom thinner than this).

While the present generation of pXRF technology does not have the same accuracy or precision as conventional XRF, and is not capable of analysing some light elements, it does have a significant advantage in that a very large dataset of good quality data can be collected rapidly and cheaply. We are not suggesting that pXRF should replace conventional XRF. Instead, in line with the plea of Bédard and Barnes (2010) that geochemical data be fit for purpose, we are suggesting that the data produced by $\mathrm{pXRF}$ analyses are fit to answer geologically-important questions, such as what controls the focusing of $\mathrm{Au}$ mineralisation, as described here. 

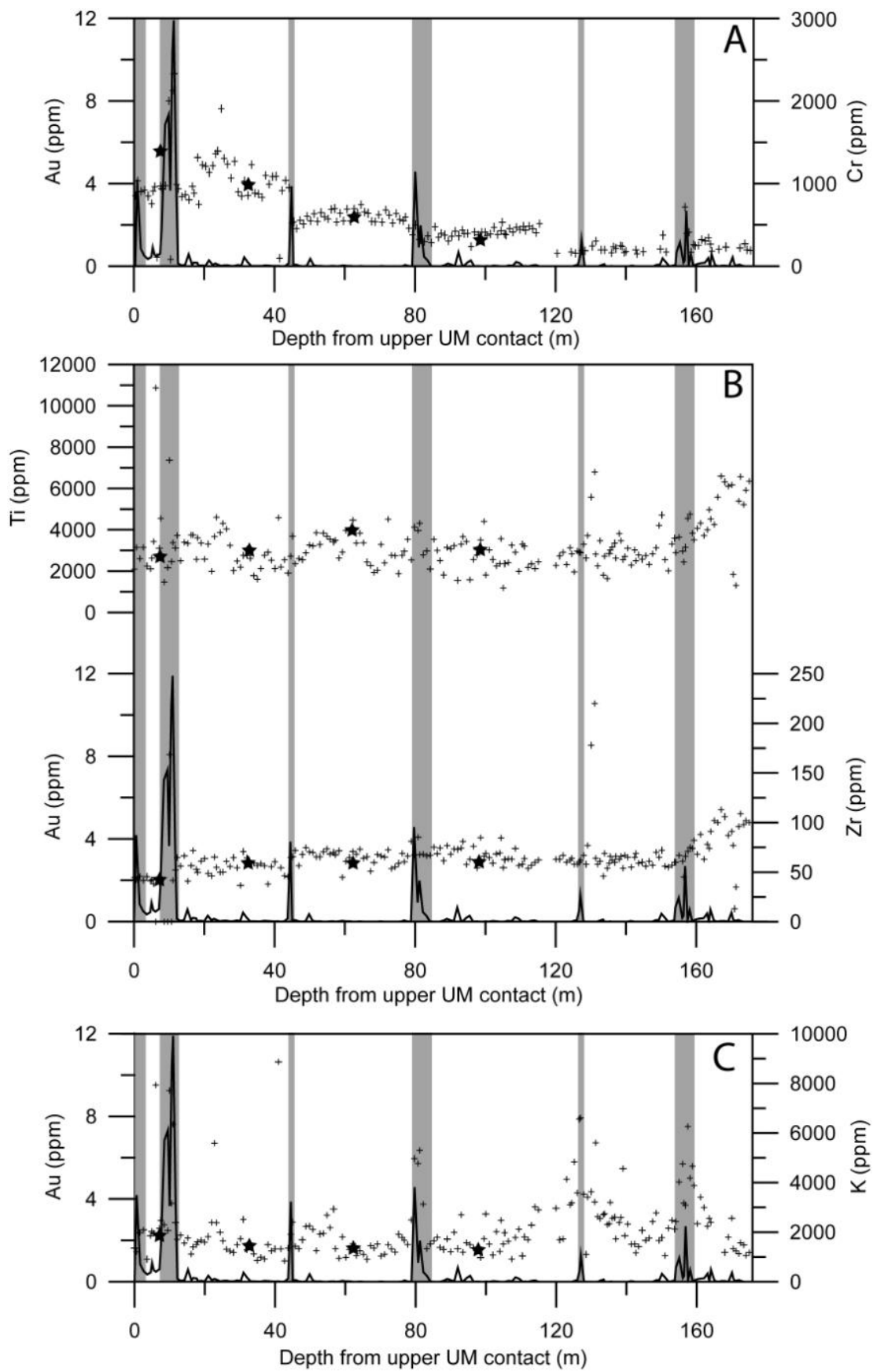

Figure 2.4 pXRF data for a representative section through the Mine Mafic Package showing basalt flow unit boundaries. Down-core depth is measured from the contact with the overlying ultramafic rocks, with younging direction to the right (down-section), and shaded bands mark high $\mathrm{Au}$ concentrations. Conventional XRF analyses are indicated by stars for the same samples; all analyses match our data well except for the $\mathrm{Cr}$ data point at $7 \mathrm{~m}$. (a) $\mathrm{Cr}$ (ppm) values are indicated by stars, $\mathrm{Au}$ (ppm) values are connected with a line. Abrupt changes in $\mathrm{Cr}$ concentration are interpreted to mark flow unit boundaries, where Au appears also to be concentrated. An Au-mineralised fault, and shear zone occur at $1 \mathrm{~m}$ and $\sim 11 \mathrm{~m}$, respectively, and there is a gap in the data from $116-120 \mathrm{~m}$. (b) Ti and $\mathrm{Zr}$ concentrations (in ppm) show magma fractionation trends and influxes of magma into the system at $\sim 20 \mathrm{~m}$ and $\sim 155 \mathrm{~m}$. (c) Au and $\mathrm{K}$ concentrations (in ppm), show that Au tends to be associated with high $\mathrm{K}$ at the flow unit boundaries. 


\begin{tabular}{|c|c|c|c|c|c|c|c|c|c|c|c|c|c|}
\hline \multicolumn{14}{|c|}{$\begin{array}{l}\text { Table } 2.2 \\
\text { Conventiol }\end{array}$} \\
\hline & $7.1 \mathrm{~m}$ & & & $32.0 \mathrm{~m}$ & & & $62.2 \mathrm{~m}$ & & & $7.5 \mathrm{~m}$ & & & \\
\hline & $\begin{array}{r}\text { XRF } \\
(\mathrm{ppm})\end{array}$ & $\begin{array}{l}\mathrm{pXRF} \\
(\mathrm{ppm}) \\
\end{array}$ & $\begin{array}{c}\text { Error } \\
(\%)\end{array}$ & $\begin{array}{l}\text { XRF } \\
(\mathrm{ppm})\end{array}$ & $\begin{array}{l}\mathrm{pXRF} \\
(\mathrm{ppm})\end{array}$ & $\begin{array}{c}\text { Error } \\
(\%)\end{array}$ & $\begin{array}{r}\text { XRF } \\
(\mathrm{ppm}) \\
\end{array}$ & $\begin{array}{l}\mathrm{pXRF} \\
(\mathrm{ppm})\end{array}$ & $\begin{array}{c}\text { Error } \\
(\%)\end{array}$ & $\begin{array}{r}\text { XRF } \\
(\mathrm{ppm})\end{array}$ & $\begin{array}{l}\mathrm{pXRF} \\
(\mathrm{ppm})\end{array}$ & $\begin{array}{c}\text { Error } \\
(\%)\end{array}$ & $\begin{array}{c}\text { Avg. Relative } \\
\text { Error }(\%)\end{array}$ \\
\hline $\mathrm{K}$ & 1810 & 2156 & 19.1 & 1478 & 1284 & -13.1 & 1370 & 1540 & 12.4 & 1312 & 1260 & -4.0 & 12.2 \\
\hline $\mathrm{Ti}$ & 2698 & 3105 & 15.1 & 3057 & 2755 & -9.9 & 4077 & 4467 & 9.6 & 3057 & 2770 & -9.4 & 11.0 \\
\hline $\mathrm{Cr}$ & 1382 & 954 & -31.0 & 978 & 841 & -14.0 & 582 & 680 & 16.8 & 315 & 365 & 15.9 & 19.4 \\
\hline $\mathrm{Zr}$ & 44 & 40 & -9.1 & 59 & 64 & 8.5 & 59 & 71 & 20.3 & 59 & 54 & -8.5 & 11.6 \\
\hline
\end{tabular}




\section{RESULTS}

pXRF results for elements that might be expected to remain immobile during metamorphic alteration (e.g. Cr, $\mathrm{Zr}, \mathrm{Ti}$ ) have been plotted as a function of increasing depth from the contact of the Mine Mafic Package with the overlying ultramafic unit (Figure 2.4). Conventional XRF results for four samples are also shown on Figure 2.4. That figure shows that there is good correspondence between the pXRF and conventional XRF data and the variation between the two, for the most part, falls within the natural variation of the data; a detailed comparison of $\mathrm{pXRF}$ and conventional XRF data is presented in Table 2.2. Gold concentrations determined by fire assay are also shown in Figure 2.4. The most striking feature of the data is the sharp changes in $\mathrm{Cr}$ concentrations that are for the most part coincident with elevated Au concentrations. Chromium concentrations decrease down-section in a stepwise fashion. From 0 to $\sim 155 \mathrm{~m}, \mathrm{Zr}$ concentration data increase very gradually in a stepwise fashion (akin to the $\mathrm{Cr}$ concentration decreases); after $\sim 155 \mathrm{~m}$ concentrations in both $\mathrm{Ti}$ and $\mathrm{Zr}$ increase quite rapidly to the end of the section. Figure $2.4 \mathrm{c}$ shows concentration data for $\mathrm{Au}$ and $\mathrm{K}$, with a strong correlation between $\mathrm{Au}$ and peaks in $\mathrm{K}$ concentration. A complete table of pXRF data is presented in Appendix 1.

\section{DISCUSSION}

Whole-rock XRF analyses and single mineral analyses have long been used to trace fractionation trends and to mark influxes of new batches of primitive mantle-derived magma introduced into a magma chamber (Cawthorn and McCarthy, 1980; 1985; Hiemstra, 1985; Gain, 1985; Cawthorn et al., 1988). If a magma chamber is not replenished by injections of new magma, compatible elements like $\mathrm{Cr}$ should become progressively depleted in the later-erupted flows if a Cr-bearing phase is removed 
from the melt, and incompatible elements such as $\mathrm{Zr}$ (and Ti until Fe-Ti oxide crystallisation) should become progressively enriched, assuming that erupted lavas are tracking the progressive fractionation of magma in a single homogenous feeder chamber.

Systematic conventional XRF analyses of $\mathrm{Cr}, \mathrm{Ni}, \mathrm{Zr}$, and $\mathrm{Ti}$ in samples from two other diamond drill holes that intersected the entire Mine Mafic Package were previously undertaken by Vickery (2004), who attempted to divide the Mine Mafic Package into different geochemical units using ratios of elements such as $\mathrm{Ti} / \mathrm{Zr}$ and Ti/Cr. This approach had some limited success, but did not identify the trends in concentration data shown by our data set. Plotting Vickery's (2004) concentration data for $\mathrm{Cr}, \mathrm{Ni}, \mathrm{Zr}$ and $\mathrm{Ti}$ variation with stratigraphic depth reveals subtle patterns similar to those shown here, but such plots were never presented.

The sharp steps in $\mathrm{Cr}$ concentration that are revealed in our section through the Mine Mafic Package (Figure 2.4a) are interpreted as marking the boundaries between individual lava flows. The plateaux in $\mathrm{Cr}$ concentration, coupled with the sharp steps between them, provide evidence that $\mathrm{Cr}$ has not been mobile over any significant distance, despite the long complex geological history of this deposit. Detailed relogging of the analysed diamond drill core indicated no evidence to suggest that these changes in $\mathrm{Cr}$ concentration reflected faulting, shearing, or intrusion of igneous units. Instead, once the flow boundaries had been identified on the basis of the geochemical data, it became possible to identify them in core on the basis of subtle features such as an increased abundance in pillow margins or amygdules, or slight changes in 
mineralogy, such as a change in the abundance of ilmenite/titanite at a hand-sample scale.

The pattern of decreasing $\mathrm{Cr}$ concentrations and increasing $\mathrm{Ti}$ and $\mathrm{Zr}$ concentrations of the lava flows with increasing depth also provides supporting evidence that the entire sequence at Plutonic is overturned. This is consistent with previous interpretations based on results of conventional whole-rock XRF analyses that showed that the most evolved lavas are at the base of the sequence, and the most primitive at the top (Rowe et al., 2002; Morgan, 2004; Vickery, 2004). This interpretation is also consistent with textural evidence, including: spinifex textures in the komatiites which overlie and underlie the Mine Mafic Package (pers. comm. S. Barnes); the relative positions of amygdules and 'clay' on pillow margins within pillow metabasalt units; the shape of the individual pillows; and apparent younging directions within some of the metasediment units.

The record of compositionally-distinct flow units shown in Figure 2.4a provides evidence that the subsequent complex deformation history did not produce large-scale structural repetitions that could be attributed to either folding or faulting in this section through the Plutonic deposit as has been previously suggested (Rowe et al., 2002; Vickery, 2004). The variation in the Mine Mafic Package thickness is thus likely to be a primary depositional feature. The absence of the Double Shale in our stratigraphic section is presumably due to the location of the drill holes used to compile our section. As the mine has been developed down-dip from the main pit, and further to the north-west, the Double Shale has become much less evident and less useful as a marker unit. Comparison of our pXRF data with recently collected, un- 
standardised pXRF data analysed directly on drill core for holes closer to the Main Pit suggest that the Double Shale would be situated around $155 \mathrm{~m}$ in our studied section. This data also shows that the Mine Mafic Package below the inferred position of the Double Shale is thicker to the south, while the Mine Mafic Package above the Double Shale thins towards the south.

At $\sim 155 \mathrm{~m}$ there is an abrupt change to lower $\mathrm{Cr}$ concentrations, and $\mathrm{Ti}, \mathrm{Zr}$ and $\mathrm{K}$ contents abruptly increase (Figure 2.4). Ti and $\mathrm{Zr}$ concentrations then increase rapidly until the end of the section. The abrupt changes in composition recorded at $\sim 155 \mathrm{~m}$ in the core are consistent with the eruption of a more evolved magma. Since the sequence is overturned, it is most likely that this change represents either an influx of a new magma into the previous magma chamber or magma being erupted from a new source. Vickery (2004) reported that tholeiites occur above, and high-K tholeiites occur below the Double Shale; the presence of the Double Shale suggests that there was a hiatus in magmatic activity at this point that allowed either of the previously described possibilities to occur.

Our new stratigraphic section (Figure 2.3b) shows that it is possible to distinguish individual basalt flow units in diamond drill core on the basis of variations in elemental concentrations. This stratigraphic section shows clearly for the first time that there is preferential Au mineralisation on the boundaries of the individual basalt flows, and that primary stratigraphy is an important factor in controlling the distribution of Au mineralisation within this largely uniform sequence of metabasaltic rocks (Figure 2.4a). The elevated Au concentrations are associated with increased concentrations of $\mathrm{K}$, consistent with the common observation of biotite in most major 
styles of Au mineralisation at Plutonic. The anomalous abundances of $\mathrm{K}$ are almost always associated with ore zones and are rarely associated with any structural feature at Plutonic that is not also associated with Au mineralisation. As $\mathrm{K}$ is a highly fluidmobile element (Dipple and Ferry, 1992), the concentration of Au together with K probably results from channelisation of Au-mineralising fluids. Channelisation of fluids probably also influenced other styles of $\mathrm{Au}$ mineralisation that developed through the long history of the deposit, including the Au that occurs in association with zones of deformation at depths of $1 \mathrm{~m}$ (a fault) and $11 \mathrm{~m}$ (a shear) in Figure 2.4.

Vickery (2004) noted that Au tended to be deposited on the contacts between the different geochemical units that could be identified, and suggested that Fe-rich basalt flows acted as a catalyst for Au deposition. Our data (see Figure 2.4a and c) indicates that fluid pathways related to competency contrasts or weaknesses resulting from the primary stratigraphy were very important controls on this generation of Au transport and deposition. The dominant foliation lies parallel to the metasediment horizons, as noted by Bagas (1999), and may have assisted with the focusing of fluid flow and $\mathrm{Au}$ mineralisation along the weaknesses, such as basalt flow tops, in the primary stratigraphy.

\section{CONCLUSIONS}

Our study has shown that it is possible to readily identify individual lava flow units on the basis of $\mathrm{Cr}$, $\mathrm{Ti}$ and $\mathrm{Zr}$ concentrations in an otherwise largely featureless sequence of metabasalts using pXRF data. Gold mineralisation was focused along flow boundaries, presumably through the action of fluids. $\mathrm{Cr}$, $\mathrm{Ti}$ and $\mathrm{Zr}$ appear to have behaved as immobile elements, and $\mathrm{K}$ appears highly mobile in ore zones and fairly 
immobile outside of them. The fractionation trends identified in data from the Mine Mafic Package at Plutonic are interpreted as a relatively simple progression consistent with evolution in a magma chamber with one probable major recharge event, and support the previous interpretation that the metabasalt sequence is overturned. Our results also provide evidence that the Mine Mafic Package is not the product of tectonic stacking of an originally thinner smaller unit as a result of deposit-scale folding or faulting.

The data presented in this paper show that systematic pXRF analyses of diamond drill core for element data have the potential to improve the understanding of stratigraphy in mineral deposits where mineralisation may be localised along unit boundaries that might otherwise be obscure. These data allow the preparation of detailed stratigraphic columns that can show where early, near-invisible Au mineralisation is likely to occur, even in monotonous packages of rocks with few marker units. 


\section{REFERENCES}

Ando, A., Kamioka, H., Terashima, S., Itoh, S., 1989. 1988 values for GSJ rock

reference samples “Igneous Rock Series”. Geochemical Journal, vol. 23, pp. 143-148.

Awan, A., 2000. Geology and structural modelling of Plutonic Gold Mine with specific reference to the area covering underground mine development. Homestake Mining Company (Australia) Ltd., unpublished report, pp. 56.

Bagas, L., 1999. Early tectonic history of the Marymia Inlier and correlation with the Archaean Yilgarn Craton, Western Australia. Australian Journal of Earth Science, vol. 46, pp. 115-125.

Bédard, L.P., Barnes, S.-J., 2010. How fit are your data? Geostandards and Geoanalytical Research, vol. 34, pp. 275-280.

Cawood, P.A., Tyler, I.M., 2004. Assembling and reactivating the Proterozoic Capricorn Orogen: lithotectonic elements, orogenies, and significance. Precambrian Research, vol. 128, pp. 201-218.

Cawthorn, R.G., McCarthy, T.S., 1980. Variations in Cr content of magnetite from the upper zone of the Bushveld Complex - Evidence for heterogeneity and convection currents in magma chambers. Earth and Planetary Science Letters, vol. 46, pp. 335343. 
Cawthorn, R.G., McCarthy, T.S., 1985. Incompatible trace element behaviour in the Bushveld Complex. Economic Geology, vol. 80, pp.1016-1026.

Cawthorn, R.G., Maske, S., de Wet, M., Groves, D.I., Cassidy, K.F., 1988.

Contrasting magma types in the Mount Ayliff Intrusion (Insizwa Complex), Transkei: Evidence from ilmenite compositions. Canadian Mineralogist, vol. 26, pp. 145-160.

Dipple, G.M., Ferry, J.M., 1992. Metasomatism and fluid flow in ductile fault zones. Contributions to Mineralogy and Petrology, vol. 112, pp. 149-164.

Fallon, M., Porwal, A., Guj, P., 2010. Prospectivity analysis of the Plutonic Marymia Greenstone Belt, Western Australia. Ore Geology Reviews, vol. 38, pp. 208-218.

Gain, S.B., 1985. The geologic setting of the Platiniferous UG-1 Chromite Layer on the Farm Maandagoshoek, Eastern Bushveld Complex. Economic Geology, vol. 80, pp. 925-943.

Gazley, M.F., Vry, J.K., Boorman, J.C., 2011. $P-T$ evolution in greenstone belt mafic amphibolites: an example from Plutonic Gold Mine, Marymia Inlier, Western Australia. Journal of Metamorphic Geology, vol. 29, pp. 685-697.

Gazley, M.F., Vry, J.K., Millet, M.-A., Handler, M.R., du Plessis, E., Baker, J.A., in submission. New timing constraints on Archean-Proterozoic gold mineralization, metamorphism, and metasomatism at Plutonic Gold Mine, Marymia Inlier, Western Australia. Mineralium Deposita. 
Groves, D.I., 1993. The crustal continuum model for late-Archaean lode-gold deposits of the Yilgarn Block, Western Australia. Mineralium Deposita, vol. 28, pp. 366-374.

Groves, D.I., Goldfarb, R.J., Gebre-Mariam, M., Hagemann, S.G., Robert, F., 1998.

Orogenic gold deposits: A proposed classification in the context of their crustal distribution and relationship to other gold deposit types. Ore Geology Reviews, vol. 13, pp. 7-27.

Groves, D.I., Goldfarb, R.J., Robert, F., Hart, C.J.R., 2003. Gold Deposits in Metamorphic Belts: Overview of Current Understanding, Outstanding Problems, Future Research, and Exploration Significance. Economic Geology, vol. 98, pp. 1-29.

Hiemstra, S.A., 1985. The Distribution of Some Platinum-Group Elements in the UG2 Chromite Layer of the Bushveld Complex. Economic Geology, vol. 80, pp. 944957.

MacDougall, D., Crummett, W.B., 1980. Guidelines for data acquisition and data quality evaluation in environmental chemistry. Analytical Chemistry, vol. 52, no. 14, pp. 2242-2249.

McMillan, N.M., 1996. Late-Archean, syn-amphibolite facies, lode-gold deposits overprinted by Palaeoproterozoic deformation, metasomatism and hydrothermal activity at Marymia, Western Australia. PhD dissertation, University of Western Australia, pp. 453. 
Mikucki, E.J., Ridley, J.R., 1993. The hydrothermal fluid of Archaean lode-gold deposits at different metamorphic grades: compositional constraints from ore and wallrock alteration assemblages. Mineralium Deposita, vol. 28, pp. 469-481.

Morgan, R., 2004. The Lithogeochemical Characteristics of the Mine Mafic Within Zone 19 (The Baltic), Plutonic Gold Mine, Western Australia. Unpublished Honours Thesis, Curtin University of Technology, pp. 203.

Morris, P.A., 2009. Field-portable X-ray fluorescence analysis and its application in GSWA: Geological Survey of Western Australia, Record 2009/7, pp. 23.

Phillips, G.N., 1986. Geology and alteration of Golden Mile, Kalgoorlie. Economic Geology, vol. 81, pp.779-808.

Phillips, G.N., Gibb, H.F.C., 1993. A century of mining at Kalgoorlie: Economic Geology Research Unit, Key Centre in Economic Geology, James Cook University of North Queensland, Contribution 45.

Phillips, G.N., Groves, D.I., Kerrich, R., 1996. Factors in the formation of the giant Kalgoorlie gold deposit. Ore Geology Reviews, vol. 10, pp. 295-317.

Pirajno, F., Jones, J.A., Hocking, R.M., Halilovic, J., 2004. Geology and tectonic evolution of Palaeoproterozoic basins of the eastern Capricorn Orogen, Western Australia. Precambrian Research, vol.128, pp. 315-342. 
Rowe, R.J., Awan, A.W., McCuaig, T.C., Sauter, P.C., Vickery, N.M., 2002.

Structural Geology of the Plutonic Gold Mine. Applied Structural Geology for

Mineral Exploration and Mining International Symposium, Kalgoorlie, WA, pp. 180 185.

Tyler, I.M., Hocking, R.M., 2002. A revision of the Tectonic Units of Western Australia. Western Australia Geological Survey, Annual Review 2000/1, 33-44.

Vickery, N.M., Buckley, P.M., Kellett, P.J., 1998. Plutonic gold deposit. Geology of Australian and Papua New Guinean Mineral Deposits; Berkman, D.A., McKenzie, D. (eds), The Australian Institute of Mining and Metallurgy: Melbourne, pp. 71-80.

Vickery, N.M., 2004. The Plutonic Gold Deposit, Western Australia: Geology and Geochemistry of an Archean Orogenic Gold System. PhD dissertation, University of New England, pp. 593.

Vielreicher, N.M., Ridley, J.R., Groves, D.I., 2002. Marymia: an Archean, amphibolite facies, hosted orogenic lode-gold deposit overprinted by Palaeoproterozoic orogenesis and base metal mineralisation, Western Australia. Mineralium Deposita, vol. 37, pp. 737-64. 


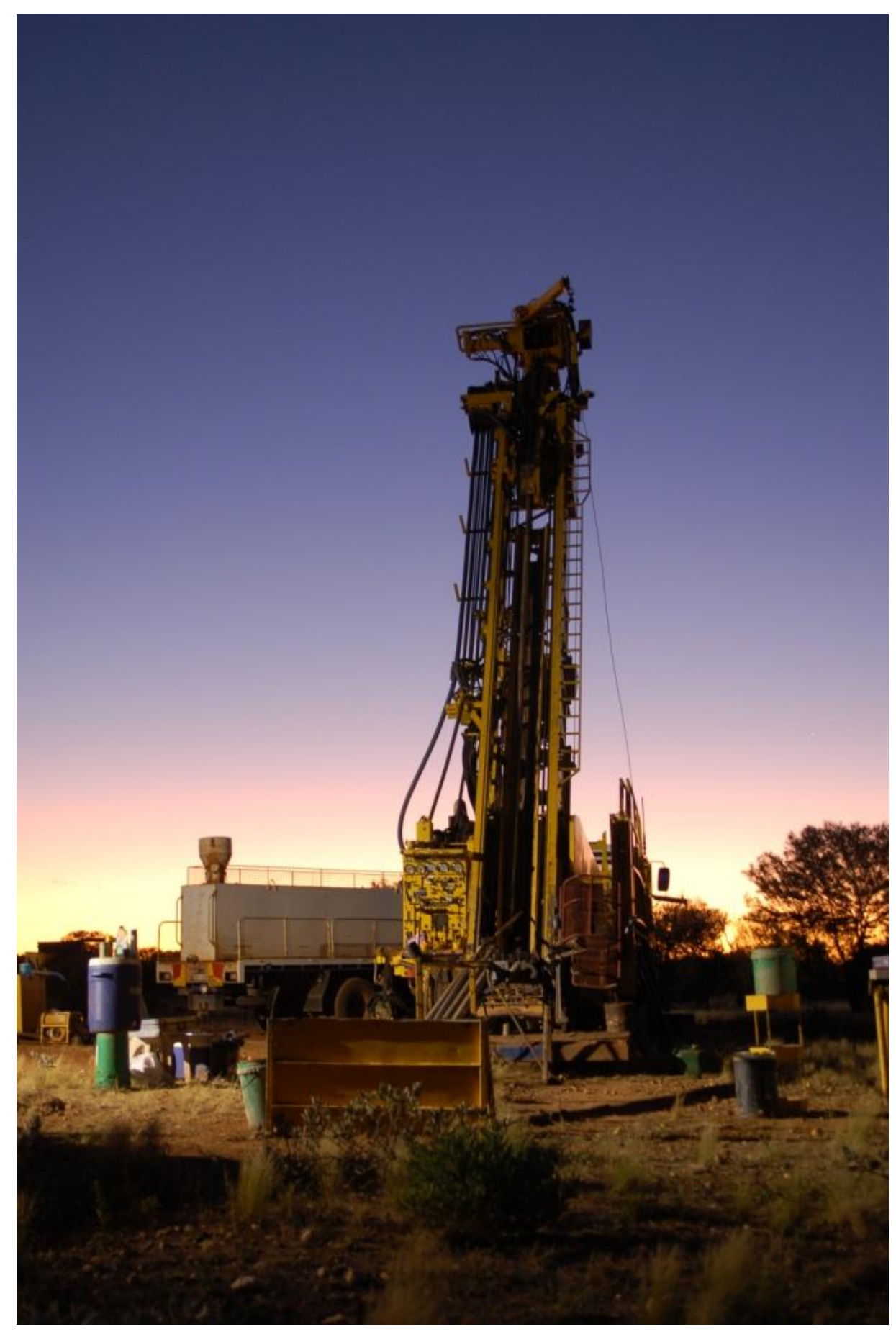

Surface drill rig at Plutonic on sunset. 


\title{
CHAPTER 3
}

\section{$P$-T EVOLUTION IN GREENSTONE BELT MAFIC AMPHIBOLITES: AN EXAMPLE FROM PLUTONIC GOLD MINE, MARYMIA INLIER, WESTERN AUSTRALIA ${ }^{4}$}

\begin{abstract}
The metamorphosed mafic rocks of Archaean greenstone belts host major orogenic gold deposits, and may record information about changing pressure-temperature $(P-$ T) conditions that could contribute to understanding of Archaean geodynamic processes. Until recently, it was difficult to obtain good constraints on pressure and temperature from these rocks. Here we present results of $P-T$ pseudosection calculations in the NCFMASHTOS $\left(\mathrm{Na}_{2} \mathrm{O}-\mathrm{CaO}-\mathrm{FeO}-\mathrm{MgO}-\mathrm{Al}_{2} \mathrm{O}_{3}-\mathrm{SiO}_{2}-\mathrm{H}_{2} \mathrm{O}-\mathrm{TiO}_{2}-\mathrm{O}-\right.$ $\mathrm{SO}_{2}$ ) system, using as our example typical amphibolite-facies metabasaltic rocks from the Plutonic Gold Mine in the Neoarchaean Plutonic Well Greenstone Belt (PWGB), Marymia Inlier, Western Australia. The pseudosections together with observed mineral compositions and mineral assemblages in the rocks, are used to argue that a previously-unrecognised steep pressure increase (from $\sim 3-4$ kbar at $\sim 500{ }^{\circ} \mathrm{C}$ to $\geq 8$ kbar at $\sim 600{ }^{\circ} \mathrm{C}$ ) accompanied metamorphism to peak temperatures. The $P-T$ data presented here could be the result of either horizontal or vertical tectonics. Existing models for the early evolution of the PWGB involve nappe stacking supported by relatively cold strong crust, with little overall change in thickness. While the available evidence from the study area and the wider region is not yet sufficient to confirm whether the peak metamorphic conditions were attained by horizontal or vertical tectonic means, the $P-T$ data presented here can provide region-specific constraints for computer modelling that may provide a more definite answer in the future.
\end{abstract}

\footnotetext{
${ }^{4}$ This chapter is formatted for, and published in Journal of Metamorphic Geology, vol 29, no. 6, pp. 685-697, after reviews from Katy Evans, Johann Diener and Richard White.
} 
Key words: amphibolite-facies mafic rocks, pressure-temperature conditions, Archaean geodynamics, THERMOCALC, Plutonic Gold Mine

\section{INTRODUCTION}

A significant proportion of the world's gold occurs in Archaean greenstone-hosted lode gold deposits where metamorphosed mafic rocks are the dominant lithology, and the gold lodes are metamorphic in origin (e.g. Goldfarb et al., 2001). Recent advances in modelling the activity-composition relationships of amphiboles (e.g. Diener et al., 2007) can now be used with petrologic forward modelling tools such as

THERMOCALC v. 3.33 (revised version of Powell and Holland (1988)) to examine the metamorphic evolution of mafic rocks in unprecedented detail. New pressuretemperature $(P-T)$ data can now be extracted directly from the abundant metamorphosed mafic rocks of Archaean greenstone belts, without reliance on rare intercalated lithologies. These new data should clarify understanding of not just the local metamorphic conditions, but also potentially the Archaean geodynamic processes that produced them.

In this study, we use two samples of amphibolite-facies metamorphosed mafic rock to investigate the changing metamorphic $P-T$ conditions that affected the southern margin of the Plutonic Well Greenstone Belt (PWGB), Marymia Inlier, Western Australia (Fig. 3.1).

\section{GEOLOGICAL SETTING}

The samples for this study were collected from the main underground mine at 


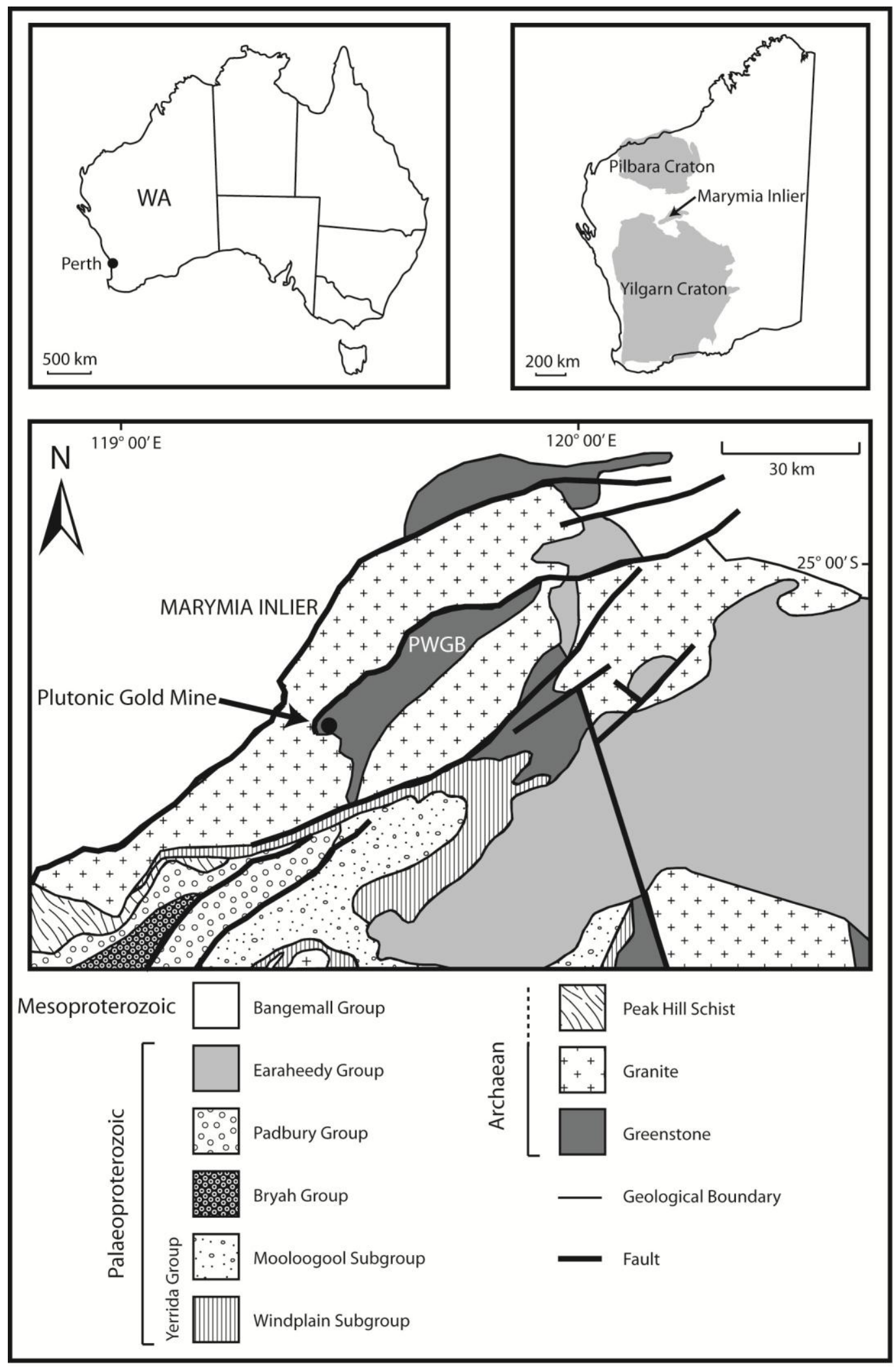

Figure 3.1 Simplified location and geological map for the Marymia Inlier, modified after Bagas (1999). Insets show location of Marymia Inlier in Australia, in relation to the Pilbara and Yilgarn cratons in West Australia (modified after Tyler \& Hocking, 2002). PWGB = Plutonic Well Greenstone Belt. 
Plutonic Gold Mine (Plutonic). The mine, which has a total endowment of 10.5 million ounces of gold (Fallon et al., 2010), is owned and operated by Barrick Gold Australia Pacific, and is located approximately $800 \mathrm{~km}$ north-east of Perth, Western Australia. Plutonic is located at the south-western end of the PWGB, a northeastsouthwest trending, $50 \mathrm{~km}$ long, $10 \mathrm{~km}$ wide Neoarchaean granite-greenstone terrane the Marymia Inlier (Fig. 3.1). The Marymia Inlier is a basement high located between the Pilbara and Yilgarn cratons, which is surrounded by Proterozoic rocks. It was uplifted during the Capricorn Orogeny $(\sim 1830 \mathrm{Ma})$ during a collisional event between the two cratons (Bagas, 1999; Pirajno et al., 2004).

Economic orogenic gold deposits occur in the Marymia Inlier and parts of the Pilbara and Yilgarn cratons in Western Australia. From structural studies it has been inferred that early thrust-stacking affected many of these areas (e.g. Swager \& Griffin, 1990, and references therein), including the Archaean greenstone sequences of the PWGB (e.g. Bagas, 1999; Rowe et al., 2002). In the PWGB this episode of deformation accompanied the onset of metamorphism to peak conditions in the amphibolite facies at 2660-2630 Ma (McMillan, 1996; Rowe et al., 2002; Vielreicher et al., 2002; Vielreicher \& McNaughton, 2002; Vickery, 2004). Prior to this present study, the maximum metamorphic pressures were inferred to be low, and any resulting crustal thickening was considered to have been minimal (Bagas, 1999).

Known economic concentrations of gold at Plutonic occur mainly within the Mine Mafic Package, which consists predominantly of amphibolite-facies metabasaltic rocks, with a few thin (typically $<1 \mathrm{~m}$ thick), discontinuous intraformational metasediments, including the metamorphosed equivalents of cherty, graphitic, and relatively pelitic units. U-Pb dating of zircons in cross-cutting felsic intrusions shows that the package was deposited before 2680 Ma (e.g. McMillan, 
1996; Vickery, 2004). The Mine Mafic Package varies in thickness from $<20$ to $>$ $300 \mathrm{~m}$, and is for the most part overturned (Gazley et al., 2011 (Chapter 2)). Rowe et al. (2002) suggested that overturning occurred early in the geological history of the belt, most likely before most gold mineralisation. The strong likelihood is that the overturning of such a large body of rock accompanied a major metamorphic event probably the peak metamorphic event presented here as there is no textural evidence of another metamorphic event having affected the area.

Recently-compiled geochemical cross-sections through the Mine Mafic Package show that there is no significant structural duplication of the package within the current mine workings (Gazley et al., 2011 (Chapter 2); MFG unpub. data ${ }^{5}$ ). The Mine Mafic Package can be broken into two sections, which are divided by a generally-continuous graphitic metashale known as the Double Shale. Above the Double Shale, the rocks of the Mine Mafic Package have primitive, near picritic, compositions of mid-ocean ridge basalt (MORB) affinity; while basalts below the Double Shale are calc-alkaline basalt in composition (Morgan, 2004; Vickery, 2004; MFG unpub. data $\left.{ }^{6}\right)$. Throughout the Mine Mafic Package the metabasaltic rocks are dominated by the mineral assemblage plagioclase-hornblende-sphene (titanite)ilmenite-pyrrhotite-quartz-epidote \pm chlorite \pm carbonate \pm rutile. Garnet is absent in the metabasaltic rocks of the Mine Mafic Package, and is exceedingly scarce in the unit as a whole.

The main style of gold mineralisation (Plutonic brown lode; Vickery, 2004) typically occurs as thin $(\sim 1-3 \mathrm{~m}$ wide) lodes that consist predominantly of quartzbiotite-amphibole-sphene-epidote-carbonate-tourmaline-arsenopyrite-pyrrhotite \pm chalcopyrite $\pm \mathrm{Au} \pm$ scheelite, which appear to be spatially associated with boundaries

\footnotetext{
${ }^{5}$ This unpublished data is presented in Figure 5.1.

${ }^{6}$ This unpublished data is presented as whole rock analyses in Appendix 6.
} 
between metabasalt flows. This style of gold mineralisation is widely accepted to have occurred early during the geologic history of the PWGB (e.g. McMillan, 1996;

Vickery et al., 1998; Rowe et al., 2002), and does not appear to be either spatially or temporally associated with late-stage chlorite-carbonate alteration that variably affects the Mine Mafic Package.

\section{SAMPLES}

In this paper we present $P-T$ pseudosection and geothermobarometry results for two typical samples of metabasalt from the Plutonic area, using the most pristine samples identified from the two major geochemical units of the Mine Mafic Package. Sample MG313 (more primitive) is from the upper (stratigraphically lower) unit of the Mine Mafic Package (from diamond drill hole UDD1730B at $350.0 \mathrm{~m}$ ), and MG053 (calcalkaline basalt), is from the lower (stratigraphically higher) unit (from diamond drill hole UDD1484 at $268.1 \mathrm{~m}$ ). Both samples were collected approximately $175 \mathrm{~m}$ apart from within a conformable sequence.

\section{ANALYTICAL METHODS}

\section{Whole-rock analyses}

Major element analyses of whole-rock samples were carried out by X-ray fluorescence spectrometry (XRF) at SpectraChem Analytical Ltd. (Wellington, New Zealand). The powdered rock samples were prepared at Victoria University of Wellington using a TEMA tungsten carbide mill. Loss on ignition (LOI) determinations were carried out at $1000{ }^{\circ} \mathrm{C}$ for 1 hour on $2-4 \mathrm{~g}$ subsamples, pre-dried at $110{ }^{\circ} \mathrm{C}$. Major oxides were measured sequentially in glass discs fused with a lithium borate flux, using a Siemens SRS303AS X-ray spectrometer fitted with a 3 
$\mathrm{kW}$ rhodium end window tube $(125 \mu \mathrm{m}$ Be window $)$. Concentrations were derived from Spectraplus software using matrix-corrected measured intensities against linear regression calibrations for individual oxides. Measuring times for individual oxides were optimised to achieve a practical lower limit of measurement of $0.01 \%$ for routine analyses. The XRF data were corrected for weight LOI and presented as weight $\%$ oxide, and the data was converted to mol.\% oxide for input into

\section{THERMOCALC.}

In order to include $\mathrm{Fe}^{3+}$-bearing minerals like epidote in the pseudosections, the $\mathrm{Fe}^{2+}$ and $\mathrm{Fe}^{3+}$ content of the rock bulk compositions is required. From this, the input parameter molar $\% \mathrm{O}$ can be calculated. This gives a measure of the oxygen excess required if some of the iron is $\mathrm{Fe}^{3+}$. The $\mathrm{Fe}^{2+}$ analyses were performed at the Albert-Ludwigs-Universität Freiburg, Germany, by titration following the techniques outlined in Heinrichs and Herrmann (1990). The standard CRM2115 was also analysed, and the result was $\mathrm{Fe}^{2+}=8.54 \%$ compared to the stated value of $\mathrm{Fe}^{2+}=$ $8.50 \%$; the $\mathrm{FeO}$ determinations have a $1 \sigma$ error of $0.08 \%$.

\section{Electron Microprobe}

Electron probe microanalyses (EPMA) were obtained using wavelength-dispersive spectrometry at Victoria University of Wellington, New Zealand, using JEOL JXA733 and JEOL JXA-8230 SuperProbes, with most data collected on the JXA-733. On both electron microprobes the accelerating voltage was $15 \mathrm{kV}$, and the sample current was $12 \mathrm{nA}$. Spot sizes of 1-20 $\mu \mathrm{m}$ were utilised depending on the volatile and/or alkali content of the mineral being analysed and the grain size, with analyses in the finer-grained sample MG313 being more subject to beam overlap and/or excitation 
volume effects. Photographs and back-scattered electron (BSE) images were used to locate and record the sites analysed during EPMA.

\section{Geothermobarometry}

Conventional geothermobarometry estimates were mainly obtained using the computer program GeoThermoBarometry (GTB; Spear \& Kohn, 2001), and the hornblende-plagioclase geobarometry estimates were from the calibration of Bhadra and Bhattacharya (2007).

\section{$P-T$ pseudosections}

Pressure-temperature pseudosections for two metabasaltic rock samples from the Mine Mafic Package were calculated in the ten-component system NCFMASHTOS $\left(\mathrm{Na}_{2} \mathrm{O}, \mathrm{CaO}, \mathrm{FeO}, \mathrm{MgO}, \mathrm{Al}_{2} \mathrm{O}_{3}, \mathrm{SiO}_{2}, \mathrm{H}_{2} \mathrm{O}, \mathrm{TiO}_{2}, \mathrm{O}, \mathrm{SO}_{2}\right.$ ) using THERMOCALC versions 3.33 and 3.35 , with the internally consistent thermodynamic dataset ds55S.txt (revised version of Holland and Powell (1998); K. Evans (pers. comm., 2009)), and the following activity-composition relationships: pyrite and pyrrhotite (Evans et al., 2010), amphibole (Diener et al., 2007), plagioclase (Holland \& Powell, 2003), ilmenite (White et al., 2000), chlorite (Holland et al., 1998), garnet (White et al., 2007), and diopside (Green et al., 2007). Albite, calcite, $\mathrm{H}_{2} \mathrm{O}$, rutile, sphene, and quartz were treated as pure end-members. Preliminary pseudosections were calculated in the nine-component NCFMASHTO system, after which sulphur was added and the pseudosection recalculated. For calculations in both systems, small amounts of $\mathrm{K}_{2} \mathrm{O}$ and $\mathrm{MnO}$ were ignored (see Table 3.1).

In NCFMASHTOS, the $\mathrm{S}$ content is specified as $\mathrm{SO}_{2}$. It is therefore necessary 
to account for the presence of $S$ as $\mathrm{S}^{-}$in pyrite and $\mathrm{S}^{2-}$ in pyrrhotite respectively. This is done by adjustment of the $\mathrm{O}$ content to achieve charge balance. For $\mathrm{S}^{-}$the mass balance relationship is:

$\mathrm{SO}_{2}+0.5 \mathrm{O}^{2-}=\mathrm{S}^{-}+2.5 \mathrm{O}$

i.e. for every $1.0 \mathrm{~S}$ added to the rock composition, $2.5 \mathrm{O}$ are removed. For $\mathrm{S}^{2-}$ the mass balance relationship is:

$\mathrm{SO}_{2}+\mathrm{O}^{2-}=\mathrm{S}^{2-}+3 \mathrm{O}$

i.e. for every $1.0 \mathrm{~S}$ added to the rock composition, $3.0 \mathrm{O}$ are removed. $\mathrm{O}$ in the bulk composition also allows production of $\mathrm{Fe}^{3+}$ via:

$2 \mathrm{FeO}+\mathrm{O}=\mathrm{Fe}_{2} \mathrm{O}_{3}$,

so the final expression for $\mathrm{O}$ is:

$n \mathrm{O}=n\left(\mathrm{Fe}_{2} \mathrm{O}_{3}\right)-3 n\left(\mathrm{~S}^{2-}\right)-2.5 n\left(\mathrm{~S}^{-}\right)$where $n=$ moles.

Thus, $\mathrm{O}$ acts as a measure of the redox budget of the rock (Evans, 2006). The implications of Equation 4 are that $\mathrm{O}$ can be negative, and that conversion of sulphur between oxidation states can affect the $\mathrm{Fe}^{3+}$ content of the rock if the reduced $\mathrm{S}$ content is sufficiently large. The effect of the latter implication was tested by calculating the location of a number of NCFMASHTO lines and intersections, and it was found that, for the $S$ contents used here, the introduction of $S$ into the system has a negligible effect on the stability of the other mineral phases.

\section{RESULTS}

The whole-rock analyses for the two samples and a typical MORB (Sun \& McDonough, 1989) for comparison are presented in Table 3.1. Representative mineral analyses are presented in Table 3.2 and $P-T$ determinations based on those mineral 
Table 3.1 Bulk rock compositions as input for $P-T$ pseudosection calculations

\begin{tabular}{|c|c|c|c|c|c|}
\hline & $\begin{array}{c}\text { MG053 } \\
\text { (wt.\%) }\end{array}$ & $(\mathrm{mol} . \%)$ & $\begin{array}{c}\text { MG313 } \\
\text { (wt.\%) }\end{array}$ & $(\mathrm{mol} \%$ ) & $\begin{array}{l}\text { MORB } \\
(\mathrm{mol} \%)\end{array}$ \\
\hline $\mathrm{SiO}_{2}$ & 53.79 & 58.43 & 50.14 & 52.69 & 53.11 \\
\hline $\mathrm{TiO}_{2}$ & 0.89 & 0.73 & 0.63 & 0.5 & 1.06 \\
\hline $\mathrm{Al}_{2} \mathrm{O}_{3}$ & 14.97 & 9.58 & 13.79 & 8.54 & 9.21 \\
\hline $\mathrm{FeO}$ & 9.71 & 8.75 & 9.94 & 8.84 & 8.25 \\
\hline $\mathrm{MnO}$ & 0.16 & - & 0.19 & - & - \\
\hline $\mathrm{MgO}$ & 5.25 & 8.5 & 9.75 & 15.27 & 12.86 \\
\hline $\mathrm{CaO}$ & 9.48 & 10.8 & 9.98 & 11.24 & 12.36 \\
\hline $\mathrm{Na}_{2} \mathrm{O}$ & 2.74 & 2.89 & 2.54 & 2.58 & 2.65 \\
\hline $\mathrm{K}_{2} \mathrm{O}$ & 0.26 & - & 0.38 & - & - \\
\hline $\mathrm{O}$ & - & 0.52 & - & 0.52 & 0.5 \\
\hline $\mathrm{SO}_{2}$ & 0.06 & 0.1 & 0.06 & 0.1 & n.a. \\
\hline LOI & 1.41 & - & 1.28 & - & - \\
\hline TOTAL & 98.72 & & 98.68 & & \\
\hline
\end{tabular}

MORB (Sun \& McDonough, 1989) for comparison.

LOI $=$ loss on ignition. n.a. = not analysed.

analyses are presented in Table 3.3. Abbreviations used in the tables and figures follow the recommendations of Kretz (1983).

\section{Petrography}

The two samples studied (MG313 and MG053) represent the most pristine examples of the two compositional units of the metabasalt from the Mine Mafic Package. A representative photomicrograph and a BSE image of sample MG053 are presented in Fig. 3.2a and b. In common with metabasalts from throughout the section, these two samples have mineral assemblages dominated by plagioclase and hornblende, with minor ilmenite, sphene (titanite), pyrrhotite, quartz, and epidote \pm chlorite \pm carbonate 
\pm rutile. Sphene partly replaces ilmenite, which could have been inherited from the

basaltic protolith (e.g. Diener et al., 2005); and rutile may also be present (Fig. 3.2c).

Carbonate occurs in texturally-late veinlets that typically contain chlorite and can

have epidote selvages (e.g. Fig. 3.2d). These observations are consistent with the

Table 3.2 Representative electron microprobe analyses of amphibole and plagioclase, from sample MG053.

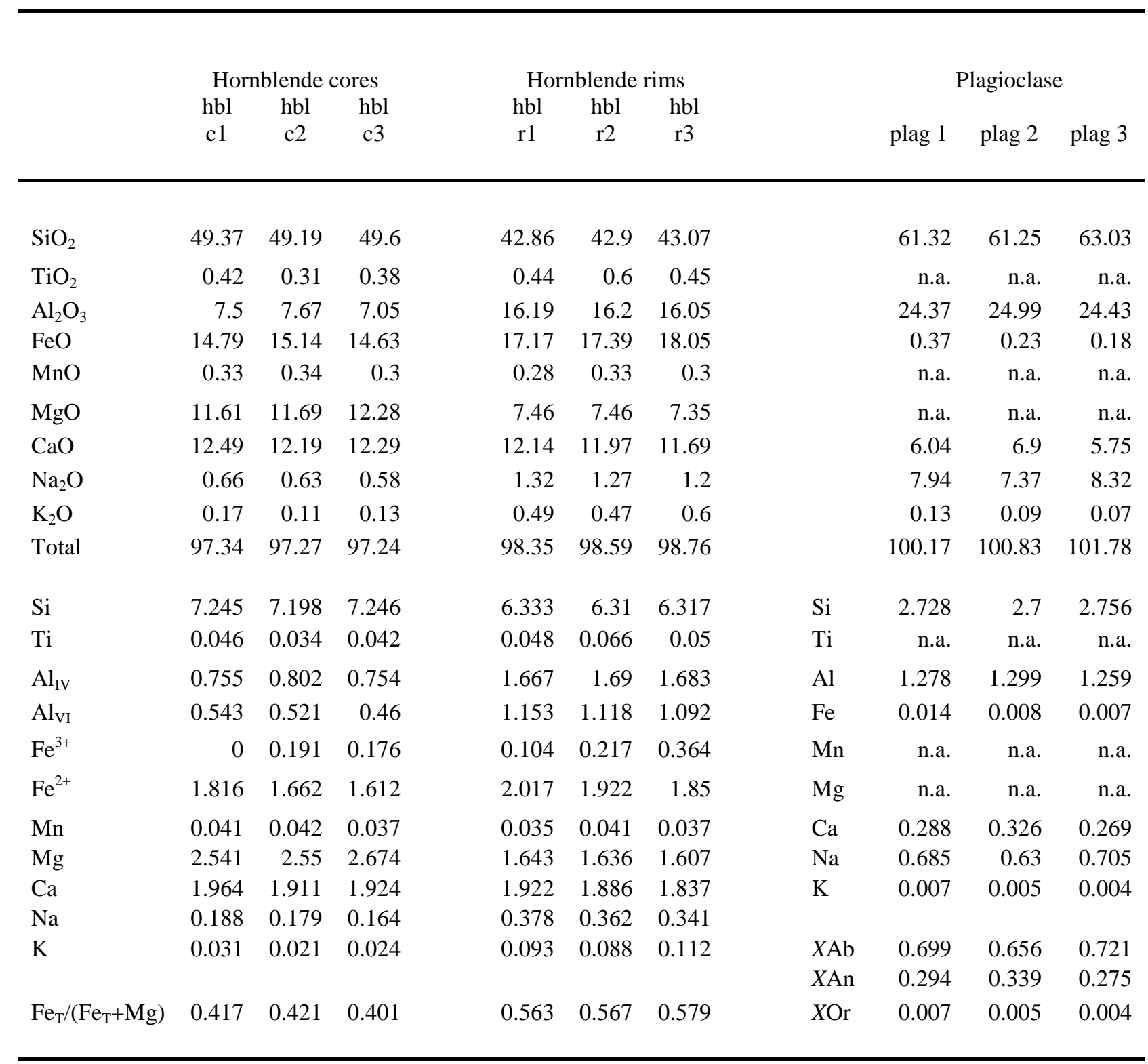

Amphibole structural formulae normalised to 23 oxygen following Tindle and Webb (1994).

Plagioclase normalised to 5 cations. n.a. = not analysed. 
Table 3.3 Representative pressures and temperatures derived from mineral analyses in Table 3.2.

\begin{tabular}{lccc}
\hline & & & \\
& hbl r1 & hbl r2 & hbl r3 \\
plag 1 & $9.6 \mathrm{kbar} / 597^{\circ} \mathrm{C}$ & $10.0 \mathrm{kbar} / 613^{\circ} \mathrm{C}$ & $10.8 \mathrm{kbar} / 633^{\circ} \mathrm{C}$ \\
plag 2 & $11.1 \mathrm{kbar} / 635^{\circ} \mathrm{C}$ & $11.8 \mathrm{kbar} / 667^{\circ} \mathrm{C}$ & $12.5 \mathrm{kbar} / 685^{\circ} \mathrm{C}$ \\
plag 3 & $8.9 \mathrm{kbar} / 579^{\circ} \mathrm{C}$ & $9.3 \mathrm{kbar} / 597^{\circ} \mathrm{C}$ & $10.2 \mathrm{kbar} / 616^{\circ} \mathrm{C}$ \\
\hline
\end{tabular}

Hornblende-plagioclase thermometry after Holland and Blundy (1994).

Hornblende-plagioclase barometry after Bhadra and Bhattacharya (2007).

interpretation that carbonate, chlorite, and at least some of the epidote is texturally late, and that the carbonate is externally derived. Both samples are very fine-grained, with amphibole crystals typically less than $100 \mu \mathrm{m}$ long in MG053 (see Fig. 3.2a) and even smaller in MG313.

The mineral assemblage of the metamorphosed calc-alkaline basalt MG053 is typical of the metabasalts in the Mine Mafic Package and contains hornblende, plagioclase, ilmenite, sphene, pyrrhotite, epidote and quartz. Carbonate, chlorite, and at least some of the epidote occur in or along thin cross-cutting veins, and are texturally late, and ilmenite is largely replaced by sphene. A BSE image shows that the hornblende is sharply zoned, with slightly brighter rims that are probably attributable to a relatively subdued increase in Fe (Fig. 3.2b, Table 3.2). The coreovergrowth boundary is regular rather than corroded, and on this basis, the cores are unlikely to be corroded remnants from a previous metamorphic event. 
Furthermore, MG313 is petrographically similar to MG053 but the hornblende crystals have actinolite cores, and rare rutile occurs adjacent to ilmenite within sphene overgrowths on ilmenite (Fig. 3.2c). Although it is unclear whether this rutile formed after ilmenite in the original igneous setting (cf. Force, 1991; p. 48), or grew prior to at least some sphene during metamorphism, the textures are consistent with the latter option.
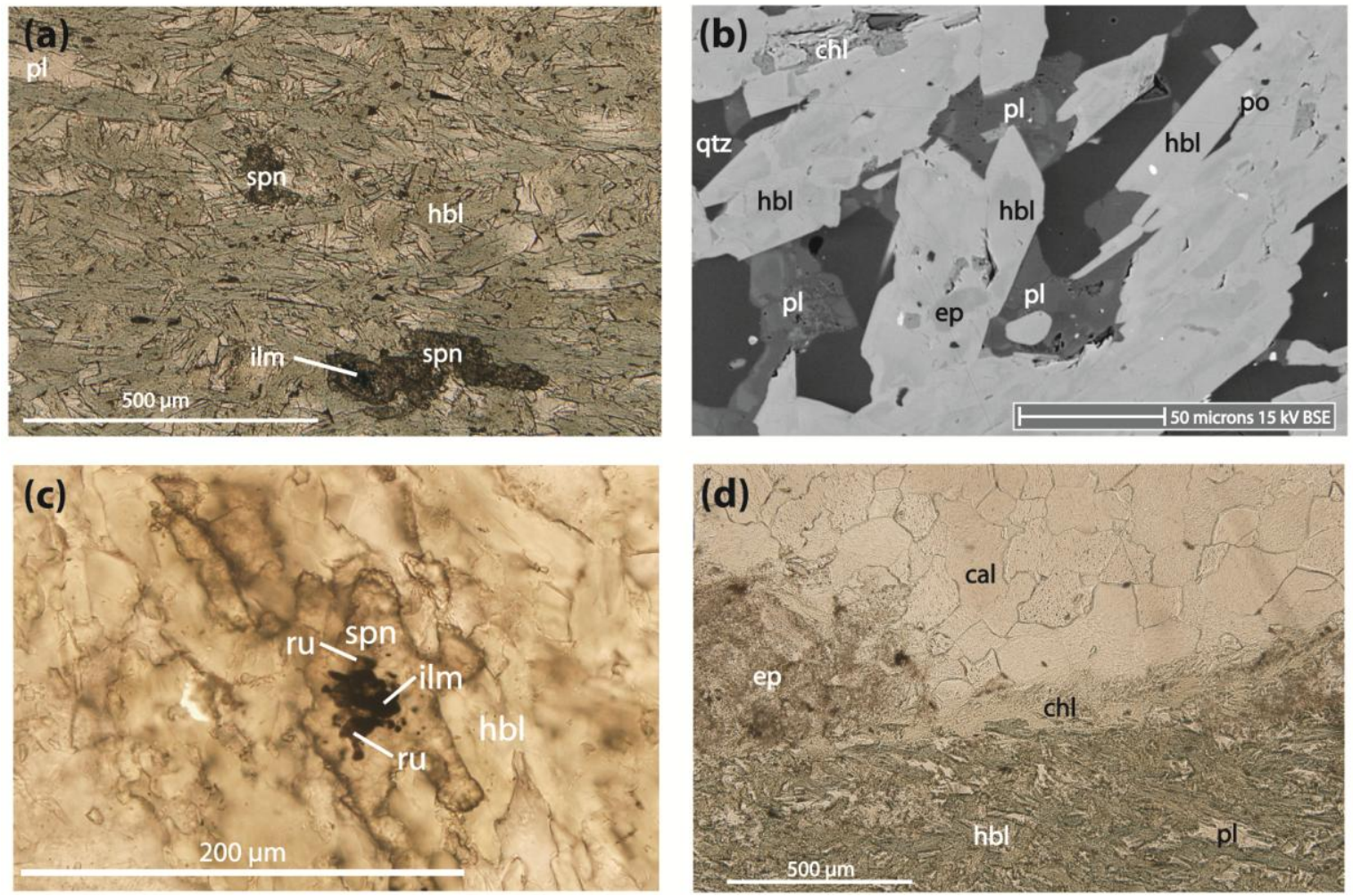

Figure 3.2 (a) Thin-section view of typical pristine metabasalt (MG053). Plane-polarised illumination. Rare quartz occurs in association with the plagioclase. Epidote occurs most commonly as inclusions within hornblende (see Fig. 3.2b). Mineral abbreviations in this and other figures follow the recommendations of Kretz (1983). (b) BSE image of metabasalt MG053. Note sharp change in hornblende compositions from core to rim. (c) Rare rutile (translucent) occurs on ilmenite (opaque) inside sphene (high relief). Thin section view (MG313), plane polarised illumination. (d) Thin-section view of a late-stage carbonate vein cross-cutting the fabric of metabasalt (MG053), plane-polarised illumination. Chlorite and epidote alteration are localised in the selvedge of the vein and do not affect the hornblende and plagioclase away from the vein.

\section{Mineral chemistry}

Representative amphibole and plagioclase analyses for the more evolved sample MG053 are presented in Table 3.2. The rims of the hornblende are brighter in BSE images and have higher $\mathrm{Al}(\mathrm{VI}), \mathrm{Na}$ and $\mathrm{Fe} /(\mathrm{Fe}+\mathrm{Mg})$ contents than the cores (see 
Table 3.2). The core vs. rim results for $\mathrm{Al}(\mathrm{VI})$ and $\mathrm{Na}$ in hornblende are $\sim 0.51$ to $\sim$ 1.12 and $\sim 0.18$ to $\sim 0.36$ atoms per formula unit (pfu), respectively (see Table 3.2). The $\mathrm{Fe} /(\mathrm{Fe}+\mathrm{Mg})$ contents for the hornblende are $~ 0.41$ to $\sim 0.57$ (see Table 3.2). The plagioclase in MG053 is zoned, with XAn contents of $\sim 0.26$ to $\sim 0.30$ for cores and rims respectively.

In sample MG313 actinolite cores are overgrown by hornblende that shows a similar pattern of rimward compositional zoning to MG053. The plagioclase is only weakly zoned. More detailed documentation of the mineral compositions in MG313 was precluded by the much finer grain size of this sample.

\section{Geothermobarometry}

Peak metamorphic pressure and temperature estimates for MG053 are 10 kbar and $600{ }^{\circ} \mathrm{C}$, based on results of hornblende-plagioclase thermometry (Holland \& Blundy, 1994) and hornblende-plagioclase barometry (Bhadra \& Bhattacharya, 2007), using the rim compositions for both minerals (Table 3.3). Probable uncertainties on the estimates are $\pm 2 \mathrm{kbar}$ and $\pm 50{ }^{\circ} \mathrm{C}$, in line with the recommendations of Powell and Holland (2008). It was not possible to confidently determine prograde metamorphic conditions from plagioclase-hornblende pairs in MG053 as at a fine scale the plagioclase zoning is more complex than is apparent in the BSE image (Fig. 3.2b).

\section{$P-T$ pseudosections for metabasaltic rocks}

A $P-T$ pseudosection for the more primitive metabasalt sample MG313 is presented in Fig. 3.3. Shading is used to indicate the variance of mineral assemblages, with higher-variance fields shaded darker. The location and orientation of the pyritepyrrhotite transition is consistent with that shown by Evans et al. (2010) for a 
metabasaltic rock from Kalgoorlie, Western Australia, with pyrrhotite stable at temperatures above $\sim 500{ }^{\circ} \mathrm{C}$, and pyrite stable at lower temperatures. The field within which both sulphides are stable widens at pressures above those considered by Evans et al. (2010). In MG053 the pyrite-pyrrhotite transition is represented by a field at $400-450{ }^{\circ} \mathrm{C}$, at pressures $~ 2-8 \mathrm{kbar}$.

The main petrographic constraints on the peak metamorphic $P-T$ conditions in MG313 are the presence of hornblende, pyrrhotite, sphene, and plagioclase, and the absence of diopside. The rock textures show that sphene replaced ilmenite and was the stable titanium phase at the peak metamorphic conditions. In MG313, minor rutile also occurs, typically in textures where ilmenite is remnant, rutile grew on the ilmenite, and both ilmenite and rutile are overgrown by sphene (Fig. 3.2c). As discussed earlier, we interpret the rutile in sphene to have grown during prograde metamorphism.

At $\sim 600{ }^{\circ} \mathrm{C}$, the presence of rutile together with sphene would be consistent with pressures of about $7 \mathrm{kbar}$; sphene without rutile would indicate pressures above $7.5 \mathrm{kbar}$; and the presence of epidote would indicate that pressures could have been as high as $\sim 9 \mathrm{kbar}$. These features are consistent with peak metamorphism at $\geq 8 \mathrm{kbar}$ and $\sim 600{ }^{\circ} \mathrm{C}$, either in the amphibolite, or epidote-amphibolite facies. This estimate is in reasonable agreement with that obtained based on results of hornblende-plagioclase thermometry (Holland \& Blundy, 1994) and hornblende-plagioclase barometry ( 10 \pm 2 kbar at $\sim 600 \pm 50{ }^{\circ} \mathrm{C}$ in sample MG053 using the calibration of Bhadra \& Bhattacharya, 2007).

The $P-T$ pseudosection for the more evolved metabasalt, MG053, is presented in Fig. 3.4. The stability fields for epidote and diopside are expanded, but otherwise the overall topology is similar to MG313, except that the extension of the rutile 
stability field down to low pressures is absent, consistent with the absence of rutile in the rock. Overall, the observed mineral assemblage in MG053 is less restrictive in terms of $P-T$ conditions than that of MG313. The presence of actinolite cores in hornblende from sample MG313, and the absence of early-formed albite, is evidence that the early metamorphic history occurred at low pressures and relatively high temperatures (see Figs 3.3 and 3.4).

Further evidence for significant pressure increase during metamorphism is presented in Figs 3.5a-c. The calculated isopleths for both $\mathrm{Al}(\mathrm{IV})$ and $\mathrm{Fe} /(\mathrm{Fe}+\mathrm{Mg})$ in hornblende in MG053 (Figs 3.5b and c) increase with increasing pressure throughout a relevant range of $P-T$ conditions as hornblende grows (mode hornblende increases (Fig. 3.5a)). Although the correspondence between measured and predicted hornblende compositions is not perfect, the trends are consistent with a steep pressure increase with little increase in temperature. The measured core-to-rim Al(IV) values are $\sim 0.51$ to $\sim 1.12$ atoms per formula unit, and the corresponding $\mathrm{Fe} /(\mathrm{Fe}+\mathrm{Mg})$ values are $\sim 0.41$ to $\sim 0.57$. The predicted values for $\mathrm{Al}(\mathrm{IV})$ and $\mathrm{Fe} /(\mathrm{Fe}+\mathrm{Mg})$ are $\sim$ 0.60 to $\sim 1.10$, and $\sim 0.43$ to $\sim 0.45$, respectively, for probable early and peak metamorphic conditions (Figs $3.5 \mathrm{~b}$ and c). The difference between the measured values (Table 3.2) and calculated predictions (Figs 3.5b and c) could be attributed to the inherent difficulty of modelling activity-composition relationships for chemicallycomplex minerals such as amphiboles. 
MG313 - NCFMASHTOS + qtz

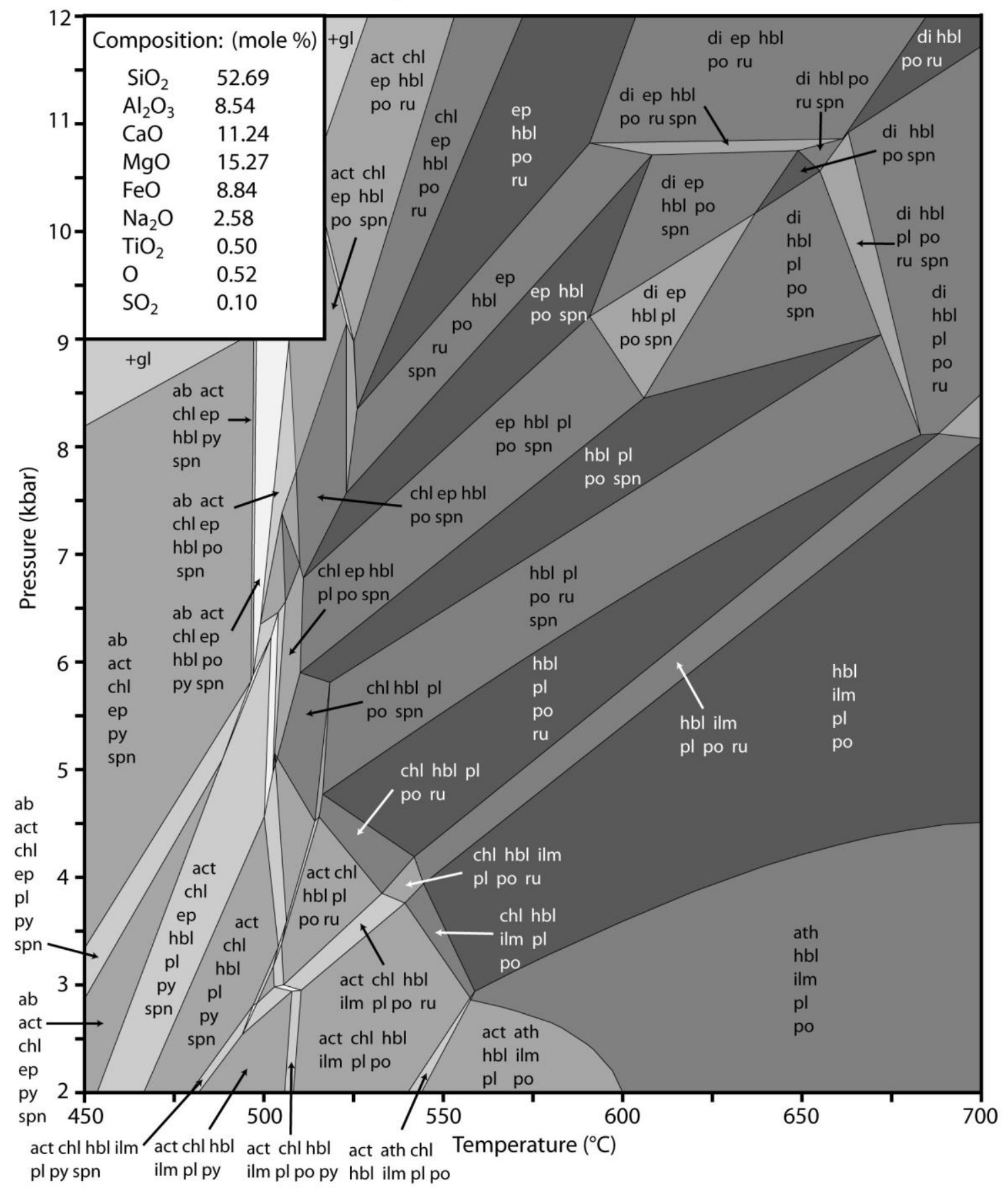

Figure 3.3 $P$-T pseudosection for MG313 in a quartz-saturated NCFMASHTOS system. 


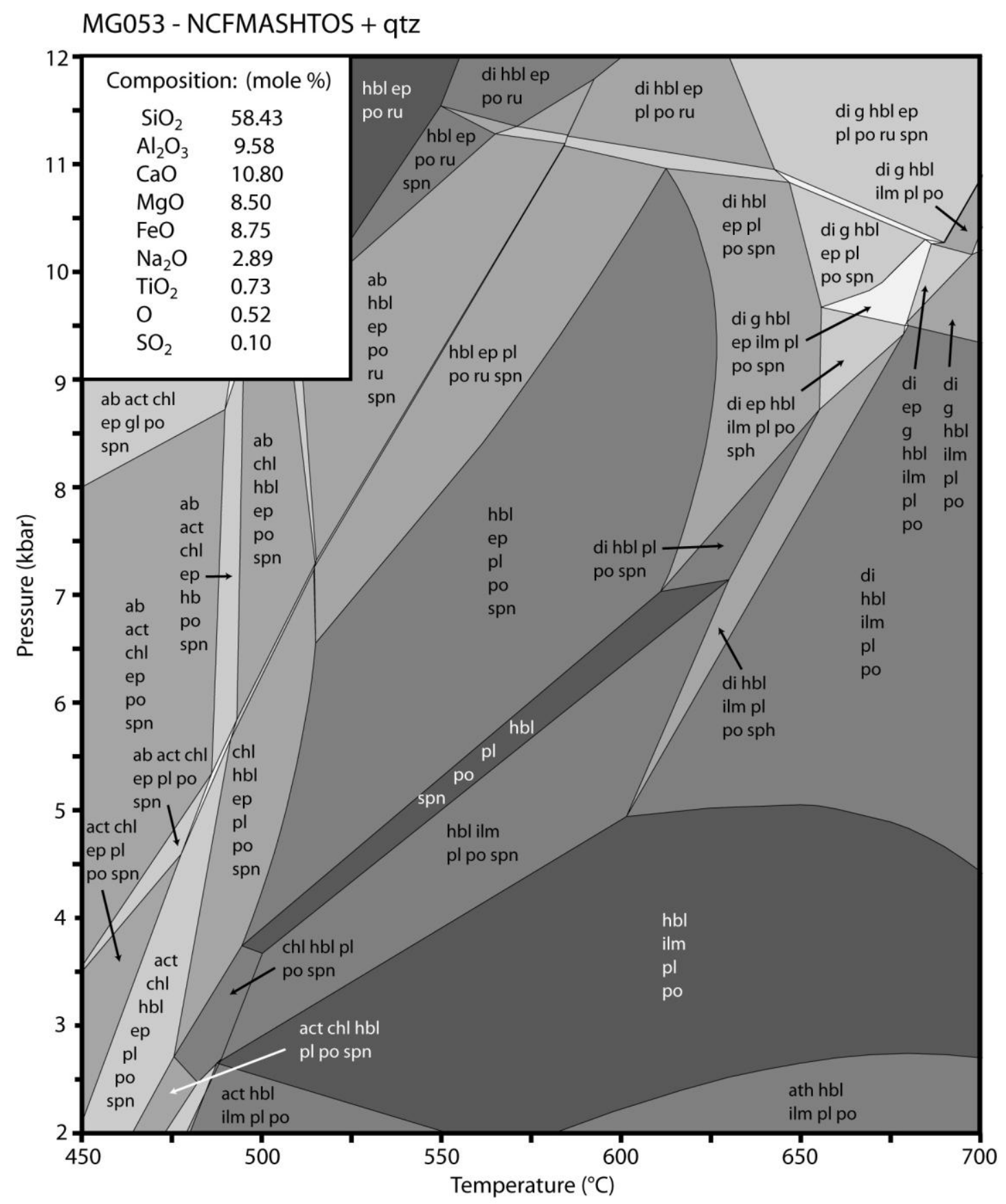

Figure 3.4 $P$ - $T$ pseudosection for MG053 in a quartz-saturated NCFMASHTOS system.

It is possible that some of the mis-match between the measured $\mathrm{Fe} /(\mathrm{Fe}+\mathrm{Mg})$ ratios of the amphiboles and those predicted by THERMOCALC could be due to an inappropriate value for ferric iron in the input bulk composition. While the wholerock powders were prepared with care to avoid late-stage veining, some was almost certainly included. The resulting whole-rock analyses thus can be expected to include 
some of the epidote alteration that is associated with the late-stage carbonate veining that oxidised the rocks.

The distinct change in the hornblende compositions from core to rim that is visible in BSE images is probably attributable to the increase in Fe (Table 3.2), as this is the heaviest of the three main elements $(\mathrm{Fe}, \mathrm{Mg}, \mathrm{Al})$ that occupy the five octahedral $\mathrm{C}$ sites. This change in composition can be explained (see Fig. 3.5c) by hornblende growth along a $P-T$ path (steeper than the $\mathrm{Al}(\mathrm{VI})$ contours presented in Fig. $3.5 \mathrm{~b}$ ) that passed through the hornblende-ilmenite-plagioclase-pyrrhotite-sphene field, where rapid changes in $\mathrm{Fe} /(\mathrm{Fe}+\mathrm{Mg})$ are predicted as ilmenite $\left(\mathrm{FeTiO}_{3}\right)$ breaks down and sphene $\left(\mathrm{CaTiSiO}_{4}\right)$ grows.

It is pertinent to consider the extent to which fractionation of elements into the distinct hornblende cores (e.g. Fig. 3.2b, Table 3.2) might affect the topology of the calculated $P-T$ pseudosections, and/or the calculated isopleths for $\mathrm{Al}(\mathrm{VI})$ in hornblende. As the studied samples contain little plagioclase, and the core-to-rim compositional change in the plagioclase is not large, the effects of compositional zoning in the plagioclase, compared to zoning in the hornblende, should be small. For these reasons, in the following section we will focus on the effects of the observed zoning in the hornblende, using sample MG053 for our example.

We estimated the relative volumetric proportions of core:rim material in hornblende ( 1:40) using measurements of length:width aspect ratios for numerous elongate hornblende crystals in photomicrographs, and measurements of the crosssectional areas of crystals and their cores in BSE images. By using this information together with the hornblende core and rim analyses and the original whole-rock bulk composition data, we were able to approximate the effective bulk composition of the rock once the hornblende cores had crystallised. We then recalculated the boundaries 
of the $P-T$ fields for the fields which constrain our inferred peak $P-T$ conditions. The resulting changes were negligible. Even doubling the volume of the cores, a change that would be readily measurable as a more than $25 \%$ increase in the width of the core in BSE images of the amphibole cross-sections, introduced only limited changes.

(a)

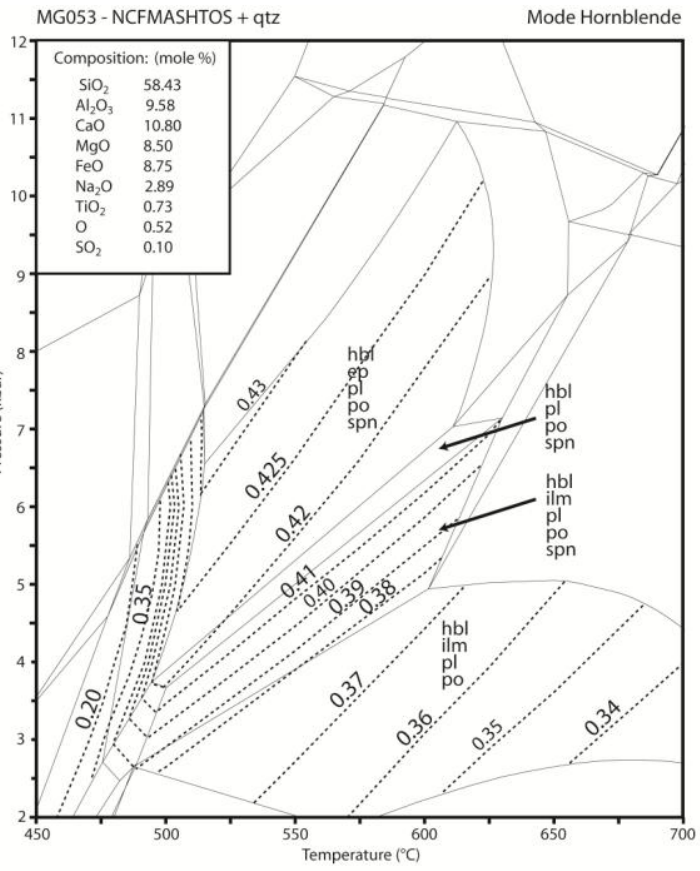

(b)

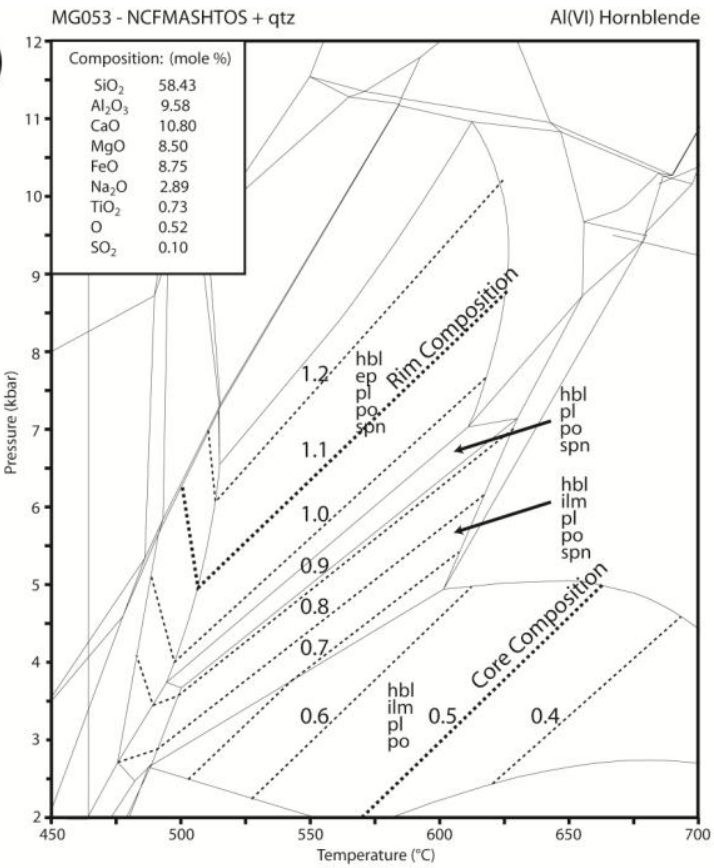

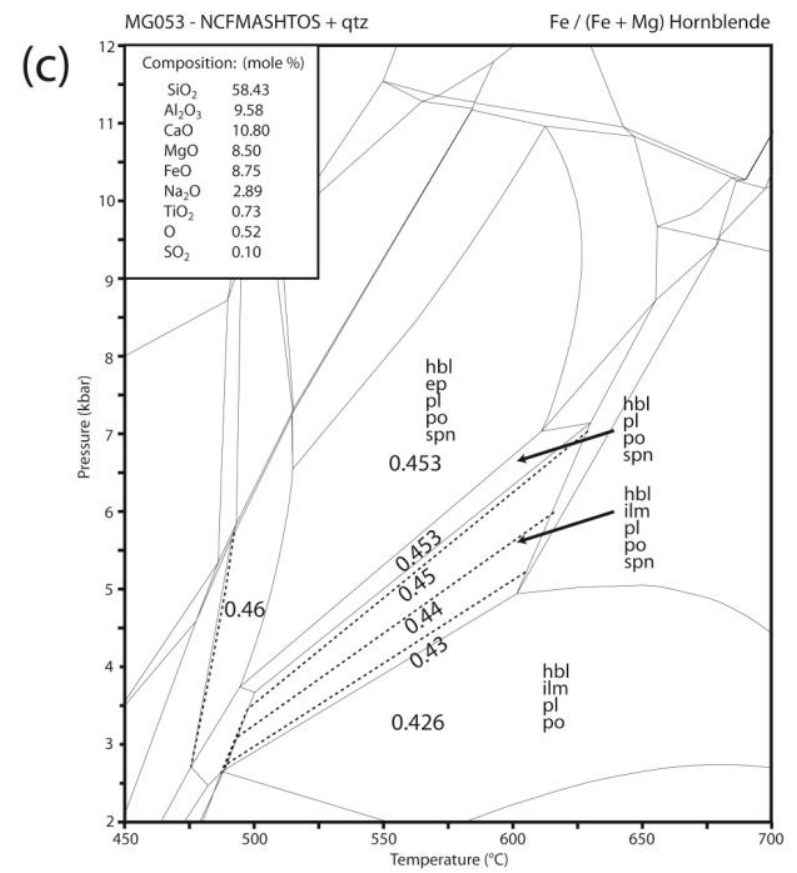

Figure 3.5 $P$ - $T$ pseudosection for MG053 in a quartz-saturated NCFMASHTOS system. (a) Contoured for mode hornblende in fields of interest. (b) Contoured for $\mathrm{Al}(\mathrm{VI})$ for hornblende in fields of interest. (c) Contoured with $\mathrm{Fe} /(\mathrm{Fe}+\mathrm{Mg})$ for hornblende in the fields of interest. 
For example, if we consider the zero mode lines that bound the hornblende-epidoteplagioclase-pyrrhotite-sphene field (see Fig. 3.4), the rutile line shifts up- $P$ from $\sim 9.0$ to $\sim 9.5 \mathrm{kbar}$ at $575{ }^{\circ} \mathrm{C}$, the epidote line shifts down- $P$ from about $\sim 6.0$ to $\sim 5.7 \mathrm{kbar}$ at $575^{\circ} \mathrm{C}$, and the diopside line shifts down- $T$ by about $\sim 10^{\circ} \mathrm{C}$; while the $\mathrm{Al}(\mathrm{VI})$ isopleths move by corresponding amounts. Based on the results of our analysis, the uncertainties attributable to the observed levels of fractionation are small and certainly within the range of typical uncertainties for geothermobarometry. Accordingly, our results and interpretations would remain largely unchanged, whether or not fractionation was considered.

By overlaying the calculated $P-T$ pseudosections for MG053 and MG313, it is possible to constrain the specific $P-T$ conditions during the metamorphism more tightly. These two nearby samples (only $175 \mathrm{~m}$ apart in the diamond drill core) should have experienced essentially the same early prograde and peak metamorphic $P-T$ conditions, in which the relevant mineral assemblages for the two samples should overlap. The same is true for the prograde conditions. The combined constraints for the early metamorphic conditions and the peak metamorphic conditions are presented in Fig. 3.6. The early prograde conditions of $475-550{ }^{\circ} \mathrm{C}$ and $3-5 \mathrm{kbar}$ are based on the presence of early actinolite in the cores of hornblende in MG313 only, and the absence of anthophyllite and albite in both samples. If the trace early rutile in MG313 (Fig.3.2c) is of metamorphic origin, then the prograde conditions can be further limited to the shaded grey field between approximately $500-550{ }^{\circ} \mathrm{C}$ and $3-4 \mathrm{kbar}$ in Fig. 3.6, based on the $P-T$ pseudosection results presented here. The use of rutile to provide these additional constraints is fully consistent with both the textural evidence and the results presented in Figs 3.5a-c. 


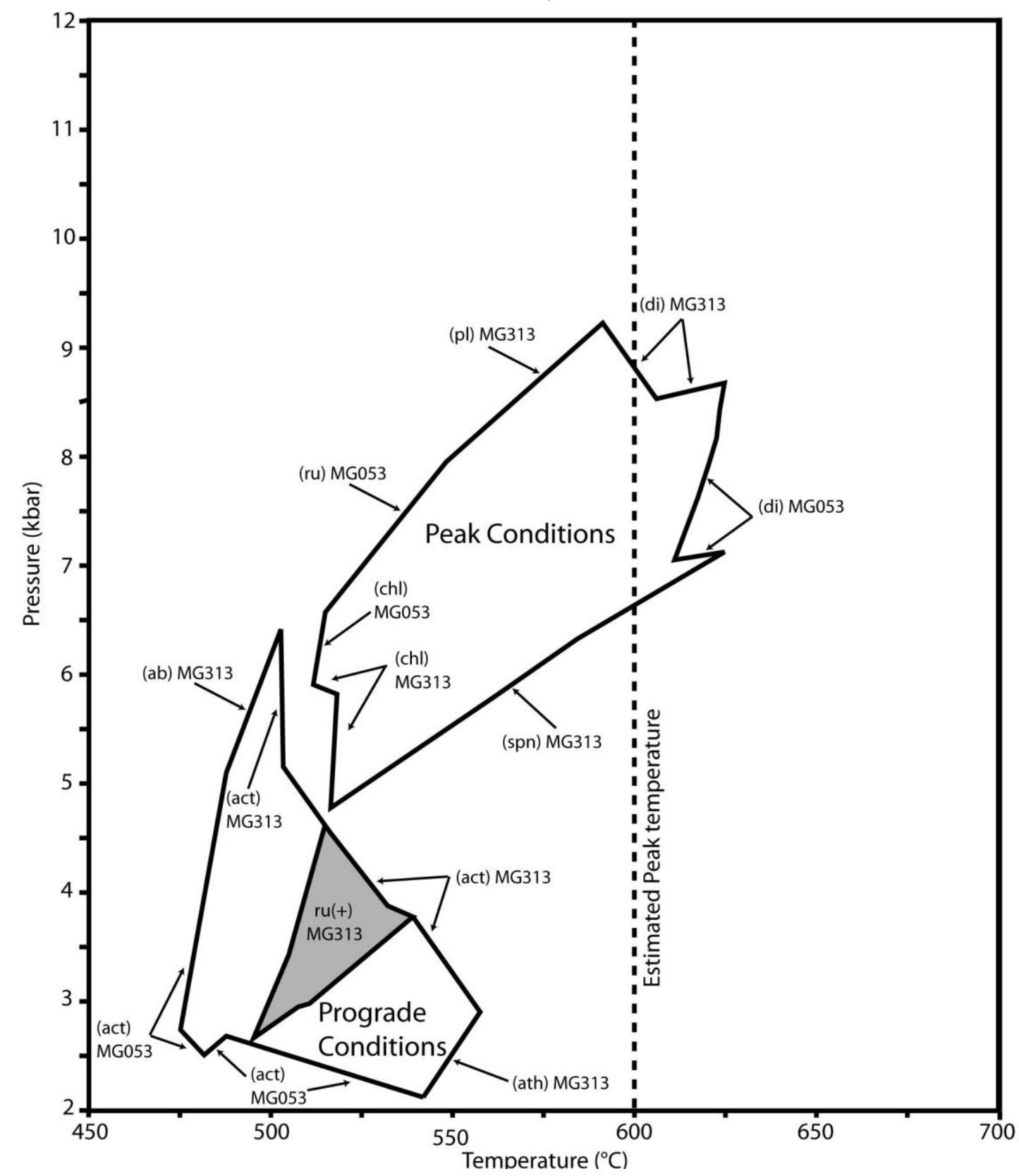

Figure 3.6 $P$ - $T$ constraints for study area have been obtained by overlaying $P$ - $T$ pseudosections for two nearby metabasalt samples MG313 and MG053. Peak conditions correspond to the region where fields containing only hornblende, sphene, plagioclase, pyrrhotite, \pm epidote overlap for both samples. Early prograde conditions (unshaded) correspond to the region where $P$ - $T$ pseudosections show actinolite (cores) in MG313, hornblende (cores) in MG053, and anthophyllite and albite are absent in both. Traces of early rutile in MG313 may restrict prograde conditions further (shaded area). Dashed line shows probable peak metamorphic temperature $\left(600^{\circ} \mathrm{C}\right)$ as determined by conventional geothermobarometry (see text). The early prograde and peak metamorphic conditions are delimited by segments of relevant zero-mode lines, which are labelled using parentheses to indicate the phase gained or lost. 
The peak metamorphic conditions are restricted to the region of overlap where hornblende, sphene, plagioclase, and pyrrhotite coexist, with or without epidote, which, on the basis of textures, is probably part of the peak assemblage. Based on Fig. 3.5, the prograde $P-T$ path would have passed through pressures around 3-4 kbar at $500-550{ }^{\circ} \mathrm{C}$, with probable peak conditions of $\sim 8 \mathrm{kbar}$ (without epidote) to $\sim 9 \mathrm{kbar}$ (with epidote) at $600{ }^{\circ} \mathrm{C}$. These inferred maximum pressures are considerably higher than the previous estimates of $\sim 4 \pm 2 \mathrm{kbar} / \sim 550-600 \pm 50{ }^{\circ} \mathrm{C}$ (cf. McMillan, 1996; Vickery, 2004).

\section{DISCUSSION}

Rutile is common in mafic rocks that have been metamorphosed to high pressures, but the possibility that small amounts of metamorphic rutile might also form at lowerpressure conditions in mafic rocks has not to our knowledge been previously suggested. The textural evidence (Fig. 3.2) and $P-T$ pseudosection results presented here for sample MG313 (Fig. 3.3) support this latter possibility, and a recent recalculation of a previously-published $P-T$ pseudosection for a metabasalt of typical MORB composition (Diener et al., 2007) also has disclosed a comparable narrow region of rutile stability at relatively low pressure conditions (J. Diener, pers. comm., 2009). There is no indication in rocks from the present study area that pressures were ever high enough to stabilise rutile as the sole titanium phase. The calculated locations of equilibria involving the titanium phases sphene, ilmenite, and rutile are particularly sensitive to slight variations in the composition of a coexisting $\mathrm{C}-\mathrm{O}-\mathrm{H}$ fluid (JKV unpubl. data), but for the chemical system considered here, the simplest interpretation is that the trace amounts of rutile identified in MG313 could be remnant from rutile that grew as pressures increased through the transition from ilmenite to sphene 
stability (see Fig. 3.3).During the course of our $P-T$ pseudosection calculations, we discovered no reasonable $P-T$ paths that would cause amphibole to be consumed and then re-grow later in the same metamorphic episode. Whether diffusion could have caused the distinctive zonation that we see in our samples also needs to be assessed. Having considered the limited data available on diffusion rates of major elements in amphibole (e.g. Cherniak \& Dimanov, 2010), it is probable that the maximum temperatures that affected the rocks at Plutonic were close to conditions at which $\mathrm{Fe}$, $\mathrm{Mg}$ and $\mathrm{Al}$ might effectively diffuse within the crystal lattice of the typical small hornblende crystals (Fig. 3.2b). However, the preservation of distinct low-Al cores provides evidence that the extent of re-equilibration was small. For these reasons, the sharp change in hornblende composition is most simply interpreted as having formed during a single progressive episode of metamorphism.

Peak metamorphism in the PWGB is generally attributed to overthrusting, and active thrust margins are well documented within the PWGB (e.g. Bagas, 1999; Rowe et al., 2002), especially along its western boundary. Prior to this study, the peak pressures for rocks at Plutonic and elsewhere in the PWGB were considered to be low ( $4 \pm 2$ kbar and $\sim 550-600{ }^{\circ} \mathrm{C}$; McMillan, 1996; Vickery, 2004), with any associated crustal thickening considered to have been minimal (Bagas, 1999). Our new peak $P-T$ estimates require a significantly larger amount of crustal thickening than those previously reported (e.g. McMillan, 1996; Vickery, 2004), and the results of our $P-T$ pseudosection calculations indicate that this thickening affected rocks that were already at high temperatures (from $\sim 3-4 \mathrm{kbar}$ at $\sim 500-550{ }^{\circ} \mathrm{C}$, to $\geq 8 \pm 2 \mathrm{kbar}$ at $\left.600 \pm 50^{\circ} \mathrm{C}\right)$.

Whether such an amount of crustal thickening by overthrusting could be supported by rocks at this temperature remains to be determined (e.g. Rey \& 
Houseman, 2006), and an alternative model of gravity-driven tectonic processes (akin to diapirism) is also conceivable (e.g. Rey et al., 2003; Chardon et al., 2009). The question of whether plate-tectonic or vertical-tectonic processes driven by gravitational instabilities affected greenstone belts in the Late Archaean is a subject of continuing debate (e.g. Rey et al., 2003; Rey \& Houseman, 2006, and references therein). It has been argued that gravitational instabilities could have led to an episode of profound crustal reworking that was followed shortly by gold mineralisation in both the Yilgarn Craton, Western Australia, and the Superior Craton, Canada (Rey et $a l ., 2003)$. The process of gravity-driven tectonics as described by Rey et al. (2003) can be summarised as follows: Impingement of a mantle plume at the base of the crust leads to magmatism, resulting in deposition of an insulating layer of greenstone rocks on top of the crust. This, coupled with heat transfer from the plume below, leads to partial melting of the underlying felsic crust 20-40 Myr after the emplacement of the plume. Gravitational instabilities develop, and the greenstone cover sinks into the partially molten crust, potentially resulting in gravitational overturning within as few as $10 \mathrm{Myr}$ after the onset of sinking. The results of recent computer modelling of such gravity-driven processes (e.g. Robin \& Bailey, 2009; Thébaud et al., 2010), show that rapid and significant pressure increases could follow hot, shallow, prograde early metamorphism, producing conditions comparable to those we describe here. New $P-T$ data, such as that presented here, obtained directly from the metamorphosed mafic rocks of Archaean greenstone belts could contribute region-specific constraints for future computer modelling (e.g. Thébaud et al., 2010) that may help resolve this debate.

It is not yet possible to conclusively show which of the above two (horizontal, or vertical) tectonic models is most appropriate for the present study area. The 
Marymia Inlier is a structurally complex area of Archaean crust and greenstone that was further deformed during the Proterozoic Capricorn Orogeny. Thrust faults mapped along the granite-greenstone contact along the western margin of the Marymia Inlier have a greenstone-down sense of movement; while thrust faults mapped along the eastern margin have a greenstone-up sense of movement. This could be consistent either with greenstone sinking through the granite, or the granite being thrust over the greenstone. Within the immediate vicinity of Plutonic, there are a number of large thrust faults, some with significant displacement on them (e.g. Rowe et al., 2002), but the resulting displacement and the amount of local duplication, if produced by horizontal tectonics, does not come close to the amount of crustal thickening required to produce the $P-T$ conditions we report for this study area. Significant portions of the PWGB are overturned, and this could be explained by either model. Overturned limbs and the appearance of overthrusting could develop either during actual overthrusting, or locally in a system driven by gravitational instability, depending on the geometry of the sinking mass of rock and the depth. The lack of detailed mapping of the local granites, of which there are a variety of different types and ages present (MFG unpub. data; pers. comm. S. Murray), means that it is not possible to recognise the presence or absence of concentric deformation zones, or other structural features that Collins et al. (1998) identified as key indicators of vertical tectonic processes. Overthrusting is problematic in that deformation of this nature may not be supported by rocks at relatively high temperatures (e.g. Rey \& Houseman, 2006). Gravity-driven tectonism is equally problematic, in that while it might readily explain the observed prograde and peak $P-T$ conditions, and locally could produce structures that are consistent with overthrusting, it might not provide a mechanism by which rocks could be exhumed rapidly enough to preserve the 
observed compositional zoning in hornblende. In light of all the arguments we have outlined here, we do not believe that the evidence available at this time allows us to categorically favour either vertical or horizontal tectonics as the mechanism by which peak metamorphic conditions were attained at Plutonic.

\section{CONCLUSION}

We have used results of detailed petrologic studies of two metamorphosed mafic rock samples and $P-T$ pseudosection calculations that incorporate recent advances in modelling the activity-composition relationships of amphiboles and sulphide minerals (e.g. Diener et al., 2007; Bhadra \& Bhattacharya, 2007; Evans et al., 2010), to reinterpret the $P-T$ history of a study area in an Archaean greenstone belt that is mineralised with gold. Our results show that the metamorphosed mafic rocks in the Plutonic area of the PWGB record a previously-unrecognised steep increase in pressure from $\sim 3-4 \mathrm{kbar}$ at $\sim 500-550{ }^{\circ} \mathrm{C}$, to $\geq 8 \mathrm{kbar}$ at $\sim 600{ }^{\circ} \mathrm{C}$. The approach that we have employed here, of overlaying THERMOCALC $P-T$ pseudosections for different-composition mafic rocks that have experienced the same metamorphic conditions, gave tighter constraints on the prograde and peak metamorphic conditions than could be achieved using a single $P-T$ pseudosection. Metamorphic devolatilisation or fluid production during exhumation could generate metamorphic fluids (e.g. Vry et al., 2010), possibly resulted in the widely-recognised major episode of mineralisation that accompanied, or shortly followed, the metamorphism peak (e.g. McMillan, 1996; Vickery et al., 1998; Rowe et al., 2002).

As noted by Diener et al. (2007) it is now possible to investigate changes in petrology in mafic rocks with the same kind of veracity as has been possible for pelitic rocks for some time. In this paper we have used hornblende-bearing 
metamorphosed mafic rocks from an Archaean greenstone belt to show that meaningful $P-T$ constraints can be derived directly from these rocks. The approach used here is readily applicable at locations where metamorphosed mafic rocks exist that are not unduly retrogressed and contain suitable mineral assemblages. The ability to extract meaningful $P-T$ constraints directly from the abundant metamorphosed mafic rocks of Archaean greenstone belts, without relying on less common intercalated rock types, should aid interpretation of the metamorphic and geodynamic history of a mineral deposit, a greenstone belt, or an inlier. 


\section{REFERENCES}

Bagas, L., 1999. Early tectonic history of the Marymia Inlier and correlation with the Archaean Yilgarn Craton, Western Australia. Australian Journal of Earth Sciences, 46, 115-125.

Bhadra, S. \& Bhattacharya, A., 2007. The barometer tremolite + tschermakite +2 albite $=2$ pargasite +8 quartz: Constraints from experimental data at unit silica activity, with application to garnet-free natural assemblages. American Mineralogist, 92, 491-502.

Chardon, D., Gapais, D. \& Cagnard., F., 2009. Flow in ultra-hot orogens: a view from the Precambrian, clues for the Phanerozoic. Tectonophysics, 477, 105-118.

Cherniak, D.J., \& Dimanov, A., 2010. Diffusion in pyroxene, mica, and amphibole. Reviews in Mineralogy \& Geochemistry, 72, 641-690.

Collins, W.J., Van Kranendonk, M.J., \& Teyssier, C., 1998. Partial convective overturn of Archaean crust in the east Pilbara Craton, Western Australia: driving mechanisms and tectonic implications. Journal of Structural Geology, 20, $1405-1424$.

Diener, J.F.A., Stevens, G., Kisters, A.F.M. \& Poujol, M., 2005. Metamorphism and exhumation of the basal parts of the Barberton greenstone belt, South Africa: Constraining the rates of Mesoarchaean tectonism. Precambrian Research, 143, 87-112.

Diener, J.F.A., Powell, R., White, R.W. \& Holland, T.J.B., 2007. A new thermodynamic model for clino- and orthoamphiboles in the system $\mathrm{Na}_{2} \mathrm{O}$ CaO-FeO-MgO- $\mathrm{Al}_{2} \mathrm{O}_{3}-\mathrm{SiO}_{2}-\mathrm{H}_{2} \mathrm{O}-\mathrm{O}$. Journal of Metamorphic Geology, 25, 631-656. 
Evans, K.A., 2006. Redox decoupling and redox budgets: Conceptual tools for the study of earth systems. Geology, 34, 489-492.

Evans, K.A., Powell, R. \& Holland, T.J.B., 2010. Internally consistent data for sulphur-bearing phases and application to the construction of pseudosections for mafic greenschist facies rocks in $\mathrm{Na}_{2} \mathrm{O}-\mathrm{CaO}-\mathrm{K}_{2} \mathrm{O}-\mathrm{FeO}-\mathrm{MgO}-\mathrm{Al}_{2} \mathrm{O}_{3}-\mathrm{SiO}_{2}-$ $\mathrm{CO}_{2}-\mathrm{O}-\mathrm{S}-\mathrm{H}_{2} \mathrm{O}$. Journal of Metamorphic Geology, 28, 667-687.

Fallon, M., Porwal, A., \& Guj, P., 2010. Prospectivity analysis of the Plutonic Marymia Greenstone Belt, Western Australia. Ore Geology Reviews, 38, 208218.

Force, E.R., 1991. Geology of titanium-mineral deposits. Geological Society of America, Special Paper No. 259, pp. 112.

Gazley, M.F., Vry, J.K., du Plessis, E., \& Handler, M.R., 2011a. Application of handheld X-ray fluorescence analyses to Metabasalt Stratigraphy, Plutonic Gold Mine, Western Australia. Journal of Geochemical Exploration, 110, 74-80.

Green, E.C.R., Holland, T.J.B., \& Powell, R., 2007. An order-disorder model for omphacitic pyroxenes in the system jadeite-diopside-hedenbergite-acmite, with applications to eclogite rocks. American Mineralogist, 92, 1181-1189.

Goldfarb, R.J., Groves, D.I. \& Gardoll, S., 2001. Orogenic gold and geological time: a global synthesis. Ore Geology Reviews, 18, 1-75

Heinrichs, H. \& Herrmann, A. G., 1990. Praktikum der Analytischen Geochemie, Springer-Verlag, Berlin-Heidelberg-New York, pp. 669.

Holland, T. \& Blundy, J., 1994. Non-ideal interactions in calcic amphiboles and their bearing on amphibole-plagioclase thermometry. Contributions to Mineralogy and Petrology, 116, 433-447. 
Holland, T. J. B., Baker, J. \& Powell, R., 1998. Mixing properties and activitycomposition relationships of chlorites in the system $\mathrm{MgO}-\mathrm{FeO}-\mathrm{Al}_{2} \mathrm{O}_{3}-\mathrm{SiO}_{2^{-}}$ $\mathrm{H}_{2} \mathrm{O}$. European Journal of Mineralogy, 10, 395-406

Holland, T. J. B. \& Powell, R., 1998. An internally consistent thermodynamic data set for phases of petrological interest. Journal of Metamorphic Geology, 16, 309343.

Holland, T.J.B., \& Powell, R., 2003. Activity-composition relations for phases in petrological calculations: an asymmetric multicomponent formulation. Contributions to Mineralogy and Petrology, 145, 492-501.

Kretz, R., 1983. Symbols for rock-forming minerals. American Mineralogist, 68, $277-279$

McMillan, N.M., 1996. Late-Archaean, syn-amphibolite facies, lode-gold deposits overprinted by Palaeoproterozoic deformation, metasomatism and hydrothermal activity at Marymia, Western Australia. Unpublished PhD thesis, University of Western Australia, pp. 453.

Morgan, R., 2004. The Lithogeochemical Characteristics of the Mine Mafic Within Zone 19 (The Baltic), Plutonic Gold Mine, Western Australia. Unpublished Honours Thesis, Curtin University of Technology, pp. 203.

Pirajno, F., Jones, J.A., Hocking, R.M. \& Halilovic, J., 2004. Geology and tectonic evolution of Palaeoproterozoic basins of the eastern Capricorn Orogen, Western Australia. Precambrian Research, 128, 315-342.

Powell, R., \& Holland, T.J.B., 1988. An internally consistent thermodynamic dataset with uncertainties and correlations: 3: application methods, worked examples and a computer program. Journal of Metamorphic Geology, 6, 173-204. 
Powell, R. \& Holland, T. J. B., 2008. On thermobarometry. Journal of Metamorphic Geology, 26, 155-179.

Rey, P.F., Philippot, P. \& Thébaud, N., 2003. Contribution of mantle plumes, crustal thickening and greenstone blanketing to the 2.75-2.65 Ga global crisis. Precambrian Research, 127, 43-60.

Rey, P.F. \& Houseman, G., 2006. Lithospheric scale gravitational flow: the impact of body forces on orogenic processes from Archaean to Phanerozoic in Buiter, S.J.H., Schreurs, G., (eds), 2006, Analogue and Numerical Modelling of Crustal-Scale Processes. Geological Society, London, Special Publications, 253, 153-167.

Robin, C.M.I, \& Bailey, R.C., 2009. Simultaneous generation of Archean crust and subcratonic roots by vertical tectonics. Geology, 37, 523-526.

Rowe, R.J., Awan, A.W., McCuaig, T.C., Sauter, P.C. \& Vickery, N.M., 2002. Structural Geology of the Plutonic Gold Mine. Applied Structural Geology for Mineral Exploration and Mining International Symposium, Kalgoorlie, WA, $180-185$.

Spear, F.S. \& Kohn, M.J., 2001. Program: GTB, GeoThermobarometry: Rensselaer Polytechnic Instute. Available at http://ees.geo.rpi.edu/MetaPetaRen/GTB_Prog/GTB.html (last accessed on 10 February 2010).

Sun, S.-s. \& McDonough, W.F., 1989. Chemical and isotopic systematic of oceanic basalts: implications for mantle composition and processes in Saunders, A.D., Norry, M.J., (eds), 1989, Magmatism in the Ocean Basins, Geological Society Special Publication No. 42, 313-345. 
Swager, C., \& Griffin, T.J., 1990. An early thrust duplex in the Kalgoorlie-Kambalda greenstone belt, Eastern Goldfields Province, Western Australia. Precambrian Research, 48, 63-73.

Thébaud, N., Duclaux, G., Gessner, K. \& Doublier, M., 3D Thermal-mechanical models of Archean dome and keel formation: insights from Southern Cross District in Tyler, I.M., Knox-Robinson, C.M., 2010, Fifth International Archaean Symposium Abstracts: Geological Survey of Western Australia, Record 2010/18, pp. 410.

Tindle, A. \& Webb, P.C., 1994. Probe-AMPH - A spreadsheet program to classify microprobe-derived amphibole analyses. Computers and Geosciences, 20, $1201-1228$.

Tyler, I.M. \& Hocking, R.M., 2002. A revision of the Tectonic Units of Western Australia. Western Australia Geological Survey, Annual Review 2000/1, 3344.

Vickery, N.M., Buckley, P.M. \& Kellett, P.J., 1998. Plutonic gold deposit. Geology of Australian and Papua New Guinean Mineral Deposits; Berkman, D.A., McKenzie, D. (eds), The Australian Institute of Mining and Metallurgy: Melbourne, pp. 71-80.

Vickery, N.M., 2004. The Plutonic Gold Deposit, Western Australia: Geology and Geochemistry of an Archaean Orogenic Gold System. Unpublished PhD thesis, University of New England, Australia, pp. 593.

Vielreicher, N.M., Ridley, J.R. \& Groves, D.I., 2002. Marymia: an Archaean, amphibolite facies, hosted orogenic lode-gold deposit overprinted by Palaeoproterozoic orogenesis and base metal mineralisation, Western Australia. Mineralium Deposita, 37, 737-764. 
Vielreicher, N.M. \& McNaughton, N.J., 2002. SHRIMP U-Pb geochronology of magnetism and thermal events in the Archaean Marymia Inlier, central Western Australia. International Journal of Earth Science, 91, 406-432.

Vry, J.K., Powell, R., Golden, K.M. \& Petersen, K., 2010. The role of exhumation in metamorphic dehydration and fluid production. Nature Geoscience, 3, 31-35.

White, R.W., Powell, R., Holland, T.J.B., \& Worley, B.A., 2000. The effect of $\mathrm{TiO}_{2}$ and $\mathrm{Fe}_{2} \mathrm{O}_{3}$ on metapelitic assemblages at greenschist and amphibolite facies conditions: mineral equilibria calculations in the system $\mathrm{K}_{2} \mathrm{O}-\mathrm{FeO}-\mathrm{MgO}-$ $\mathrm{Al}_{2} \mathrm{O}_{3}-\mathrm{SiO}_{2}-\mathrm{H}_{2} \mathrm{O}-\mathrm{TiO}_{2}-\mathrm{Fe}_{2} \mathrm{O}_{3}$. Journal of Metamorphic Geology, 18, 497-522.

White, R.W., Powell, R. \& Holland, T.J.B., 2007. Progress relating to calculation of partial melting equilibria for metapelites. Journal of Metamorphic Geology, 25, 511-527. 


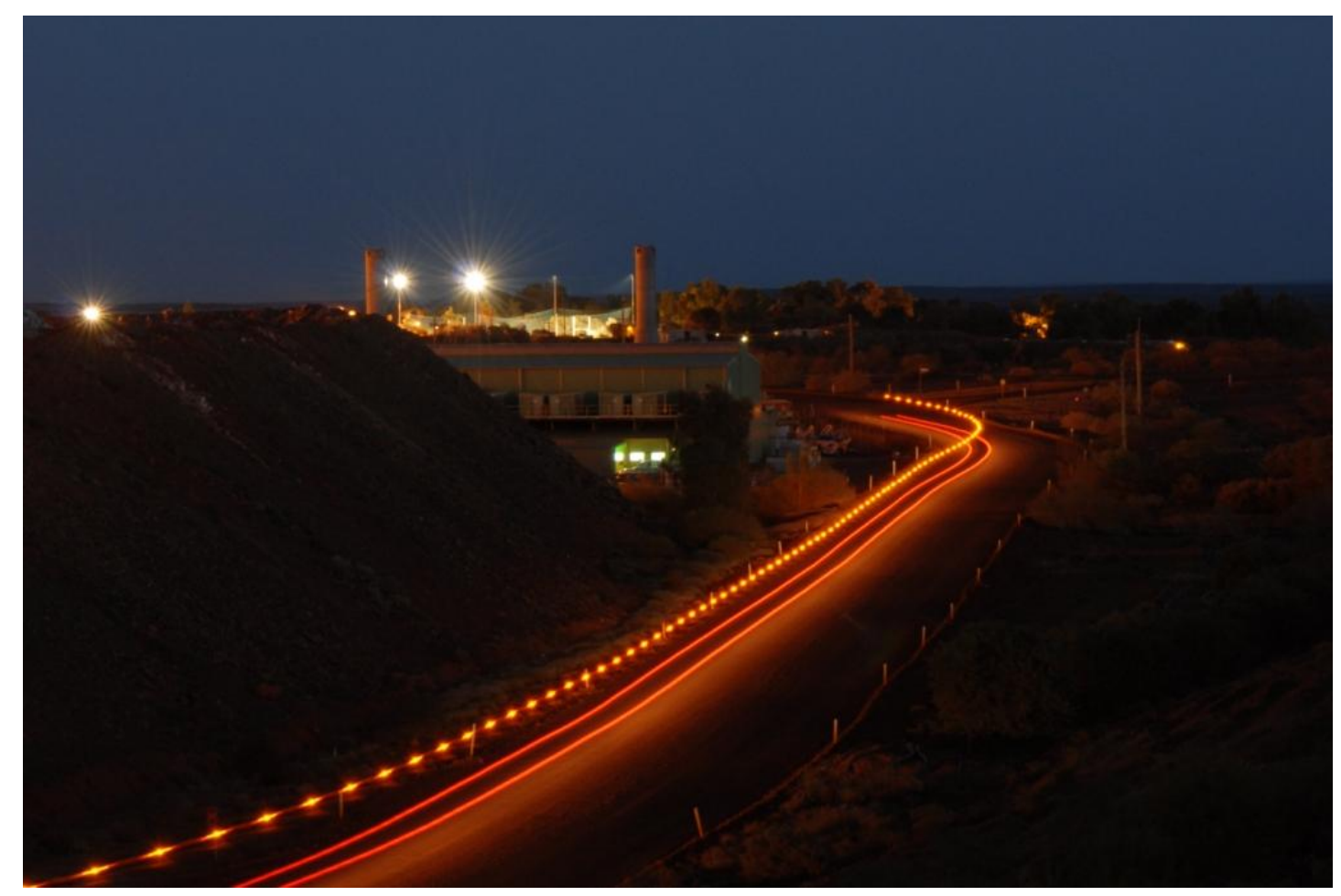

Road between camp and the underground offices. 


\title{
CHAPTER 4
}

\section{NEW CONSTRAINTS ON TIMING ON ARCHEAN-PROTEROZOIC GOLD MINERALISATION, METAMORPHISM AND METASOMATISM AT PLUTONIC GOLD MINE, PLUTONIC WELL GREENSTONE BELT, MARYMIA INLIER, WESTERN AUSTRALIA ${ }^{7}$}

\begin{abstract}
The Au-mineralized Plutonic Well Greenstone Belt (PWGB) is located in the Marymia Inlier between the Yilgarn and Pilbara cratons in Western Australia. Prior to this study, the main episode of Au mineralization in the PWGB was interpreted to have either accompanied or shortly followed the attainment of peak metamorphic conditions in the late Archean, at $2650 \mathrm{Ma}$. Here we present new Pb-isotope model
\end{abstract} ages for sulfides, $\mathrm{Rb}-\mathrm{Sr}$ ages for micas and a new ${ }^{207} \mathrm{~Pb}-{ }^{206} \mathrm{~Pb}$ age for titanite (sphene) for samples collected at Plutonic Gold Mine (Plutonic) in the southern end of the PWGB. The majority of the Au-associated sulfides record Proterozoic Pb-isotope model ages, at $\sim 2200 \mathrm{Ma}$, raising the possibility that Au-mineralization may have been widespread in the inlier and associated cratonic areas at that time. $\mathrm{An} \mathrm{Rb}-\mathrm{Sr}$ age of $2296 \pm 99$ Ma from fine-grained, texturally-early muscovite in an Au-bearing sample probably records resetting at about the same time. The $\mathrm{Rb}-\mathrm{Sr}$ age of $1779 \pm 46$ Ma from biotite from the same sample may record cooling or partial resetting during a late-stage episode of fluid flow in the PWGB. This age is possibly associated with the $\sim 1830$ Ma Capricorn Orogeny or a late-stage hydrothermal event which is constrained by a new ${ }^{207} \mathrm{~Pb}^{-206} \mathrm{~Pb}$ age of $1725 \pm 26 \mathrm{Ma}$ from titanite in a chlorite-carbonate vein. Later Au-mineralizing events are also constrained at $1830 \mathrm{Ma}$ and at $1730-1660$ Ma by $\mathrm{Pb}$-isotope model ages of Au-associated sulfides.

\footnotetext{
${ }^{7}$ This chapter is formatted for, and submitted to Mineralium Deposita on 21/06/2011.
} 
Keywords: Proterozoic gold mineralization; greenstone-hosted gold; geochronology; metasomatism; Plutonic Gold Mine

\section{Introduction}

Gold mineralization affected many parts of present-day Western Australia in the late Archean. A major episode at $\sim 2650 \mathrm{Ma}$ is recorded in the Yilgarn Craton (2670 2600 Ma; e.g. Groves et al. 2000) including the richly-mineralized Kalgoorlie area ( 2640 Ma; e.g. Vielreicher et al. 2010), as well as parts of the Marymia Inlier ( 2650 Ma; Vielreicher et al. 2002). Prior to this study, the major episode of Au mineralization at Plutonic Gold Mine (Plutonic) in the Plutonic Well Greenstone Belt (PWGB) of the Marymia Inlier (Fig. 4.1) was also interpreted to have taken place at about the same time as elsewhere in the Yilgarn Craton (e.g. McMillan 1996; Rowe et al. 2002; Vickery 2004). That interpretation drew on geochronological data from the Plutonic and the wider Marymia Inlier region (McMillan 1996; Vielreicher et al. 2002; Vielreicher and McNaughton 2002; Vickery, 2004), but included very little data that might specifically constrain the timing of Au mineralization at Plutonic. Here we present fourteen $\mathrm{Pb}$-isotope model ages for pyrrhotite, arsenopyrite, pyrite and sphalerite, two new $\mathrm{Rb}-\mathrm{Sr}$ ages for muscovite and biotite, all from Au-bearing samples, and a $\mathrm{Pb}-\mathrm{Pb}$ age for titanite (sphene) from one unmineralized sample. These new ages better constrain the timing of Au mineralization, peak metamorphism, and a late-stage metasomatic events at Plutonic. These data indicate a long history of $\mathrm{Au}$ mineralization, with a significant Au mineralization event at 2200 Ma. 


\section{Regional and local geological setting}

The samples for this study were collected from the Mine Mafic Package within the main underground mine at Plutonic. The mine, which has a total endowment of $\sim 12.2$ million ounces of $\mathrm{Au}$ (Fallon et al. 2010), is owned and operated by Barrick (Australia Pacific) Limited, and is located $\sim 800 \mathrm{~km}$ northeast of Perth, Western Australia, at the south-western end of the PWGB, in the Marymia Inlier (Fig. 4.1). The Archean Marymia Inlier is a basement high located between the Pilbara and Yilgarn cratons, and surrounded by Proterozoic rocks, it was uplifted during the Capricorn Orogeny ( 1830 Ma) - a collisional event between the two cratons (Bagas 1999; Pirajno et al. 2004). The PWGB is a northeast-southwest trending, $\sim 50 \mathrm{~km}$ long, $\sim 10 \mathrm{~km}$ wide granite-greenstone terrane in the Marymia Inlier. The early history of the PWGB is comparable to that of greenstone sequences in the Yilgarn Craton, and later features are attributable to suturing events during the Paleoproterozoic Capricorn Orogeny that brought together the Pilbara and Yilgarn cratons to form the West Australian Craton at 1830 Ma (Vielreicher et al. 2002; Cawood and Tyler 2004; Pirajno et al. 2004).

Based on results of $\mathrm{U}-\mathrm{Pb}$ sensitive high resolution ion microprobe (SHRIMP) analyses of zircon from samples collected at both Plutonic and further north in the belt, peak amphibolite-facies metamorphism in the PWGB is dated at $2660-2630$ Ma, (McMillan 1996; Vielreicher and McNaughton 2002; Vickery 2004). The main Au-mineralizing event was interpreted to have accompanied or shortly followed the peak of metamorphism in the PWGB (McMillan 1996; Vielreicher et al. 2002; Rowe et al. 2002; Vickery 2004), though there was no geochronological evidence from Plutonic to support this. The available data from Plutonic showed $\mathrm{Pb}$-isotope model ages of $\sim 2100$ Ma for pyrite in samples that were not associated with Au (Vielreicher 


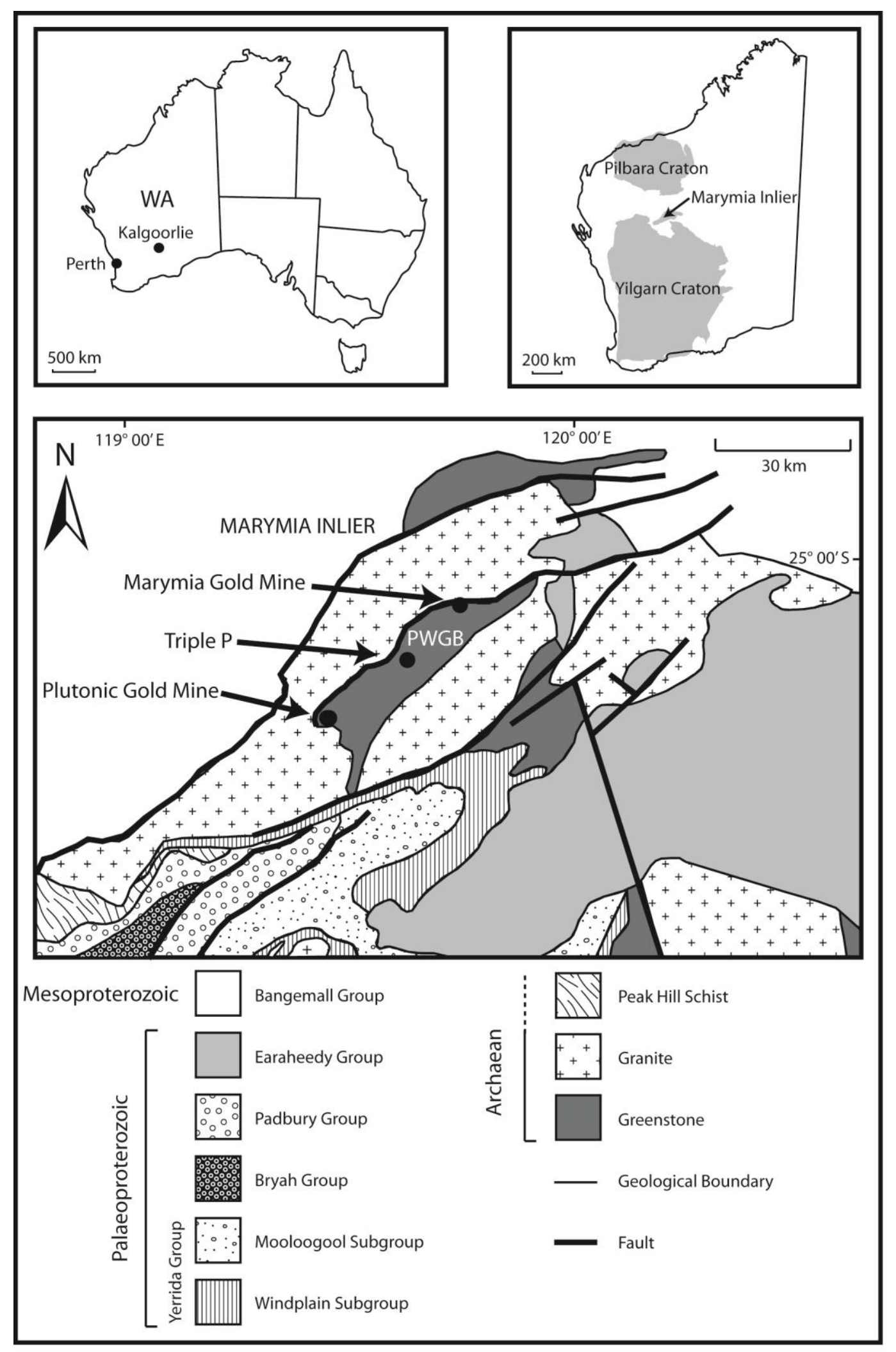

Figure 4.1 Simplified location and geological map for the Marymia Inlier, modified after Bagas (1999). Insets show location of Marymia Inlier in Australia, and in relation to the Pilbara and Yilgarn cratons in Western Australia (modified after Tyler and Hocking, 2002). 
et al. 2002), with 1730 - 1660 Ma ages obtained from galena (McMillan 1996; Vielreicher et al. 2002).

Known economic concentrations of $\mathrm{Au}$ at Plutonic occur mainly within the Mine Mafic Package. This package consists predominantly of amphibolite-facies metabasaltic rocks, which are typically high Fe- to high Mg-tholeiite in composition (Morgan 2004; MFG unpub. data ${ }^{8}$ ). Minor, thin (typically $<1 \mathrm{~m}$ ), discontinuous units within the metabasalt sequence include the metamorphosed equivalents of silica- and sulfide-rich sediments, and rock types that are interpreted as having been derived from sediments with relatively mafic bulk compositions. These minor rock types can be interlayered on a cm- to dm-scale. The metabasaltic rocks preserve pillow structures in low-strain areas, demonstrating that deposition of the Mine Mafic Package occurred in a submarine environment. The Mine Mafic Package has been divided into an upper and a lower unit by the Double Shale, a sequence of two thin, moderatelycontinuous graphitic metasedimentary units about $5 \mathrm{~m}$ stratigraphically apart. Based on results of $\mathrm{U}-\mathrm{Pb}$ dating of zircons from a narrow, cross-cutting felsic porphyry, deposition of the package occurred before 2680 Ma, (McMillan 1996; Vickery 2004). Granite, which surrounds the greenstone belt, is dated at $2720 \mathrm{Ma}$ (U-Pb dating of zircons; Vielreicher and McNaughton 2002), and appears to have been overthrust onto the greenstone sequence.

The Mine Mafic Package varies in thickness from $<20$ to $>300 \mathrm{~m}$, and is for the most part overturned (Gazley et al. 2011a (Chapter 2)). Evidence for overturning of the Mine Mafic Package can be found in komatiitic textures in the ultramafic rocks that

\footnotetext{
${ }^{8}$ This unpublished data is presented as whole rock analyses in Appendix 6 .
} 
overlie and underlie the Mine Mafic Package, and variation in elemental concentrations for sections through the Mine Mafic Package (Vickery 2004; Gazley et al. 2011a (Chapter 2)), as well as in the positions of amygdules on pillow margins within metabasalt units, the shape of the individual pillows themselves, and apparent younging directions within metasedimentary sequences of probable turbiditic origin. Recently compiled geochemical cross-sections through the Mine Mafic Package show that there is no significant structural duplication of the package within the current mine workings (Gazley et al. 2011a (Chapter 2); MFG unpub. data ${ }^{9}$ ).

Peak metamorphic conditions were $\geq 8 \pm 2 \mathrm{kbar}$ and $\sim 600 \pm 50^{\circ} \mathrm{C}$ based on results of both traditional geothermobarometry and forward modeling using THERMOCALC, and led to the formation of hornblende-plagioclase-titanite-quartz-epidote assemblages in the mafic rocks (Gazley et al. 2011b (Chapter 3)). Prograde ilmenite and rare traces of rutile can be preserved in titanite, while prograde actinolite can be preserved in the cores of hornblende, and variable amounts of carbonate, chlorite and epidote were introduced during retrogression.

\section{Gold Mineralization at Plutonic}

The Mine Mafic Package dips to the north and thins along its length from where it outcrops at the southern end of the deposit. Gold mineralization is typically confined to well-defined, narrow ( $1-3 \mathrm{~m}$ wide), biotite-bearing lodes that are sub-parallel to the dominant foliation within the Mine Mafic Package, and that tend to be nearparallel to the stratigraphy as marked by the rare metasedimentary horizons (Bagas 1999). As in many greenstone-hosted Au deposits that have been metamorphosed to

\footnotetext{
${ }^{9}$ This unpublished data is presented in Figure 5.1.
} 
high temperatures (amphibolite facies or above), the Au mineralization at Plutonic is not typically marked by a wide alteration halo (e.g. Groves et al. 1998). The Au lodes are localized into a north-south trending zone about $1 \mathrm{~km}$ wide and about $3 \mathrm{~km}$ long. In the north of the deposit a large thrust fault has folded the Mine Mafic Package back to create an upright limb in an otherwise overturned sequence. A series of large, steep faults that trend northeast-southwest cross-cut the deposit typically offsetting the Aubearing lodes. These faults do not appear to be a dominant control on $\mathrm{Au}$ mineralization, although local increases in Au grade can occur in their vicinity.

Other styles of Au mineralization also occur at Plutonic in lesser amounts; these include shear-hosted lodes, rare muscovite-rich lodes, and low- to marginallyeconomic Au grades that are associated with late-stage quartz-carbonate \pm pyrrhotite \pm chalcopyrite \pm sphalerite \pm galena that infills some faults.

The typical biotite-bearing (brown) lodes (Vickery, 2004), contain Au in association with quartz, biotite, amphibole, titanite, epidote, carbonate, tourmaline, arsenopyrite, pyrrhotite \pm chalcopyrite \pm scheelite. Brown lode is ordinarily siliceous, very fine grained, and laminated on a sub-mm scale; biotite tends to define a foliation parallel to the laminations. A weak crenulation can be present. In overall appearance brown lode can resemble a metamorphosed banded chert (Fig. 4.2a,b), with individual laminae differing in the proportions and grain sizes of biotite, quartz, and sulfides, and the nature of the sulfide or sulfide minerals present. Arsenopyrite is typically the dominant sulfide, with pyrrhotite present in varying abundance. The arsenopyrite, which is generally too fine-grained to separate from the rock for analysis, occurs preferentially in fine-grained quartz-rich laminae. The arsenopyrite crystals are for the 
most part euhedral, and are not strongly oriented. Within brown lodes, carbonate veins are typically late-stage and have no association with Au. Blebs of free Au are common and appear to be associated with epidote alteration that overprints the earlier fabrics and at least one generation of arsenopyrite; while pyrrhotite typically appears to be texturally later than the arsenopyrite (Fig. 4.2a,c).

(a)

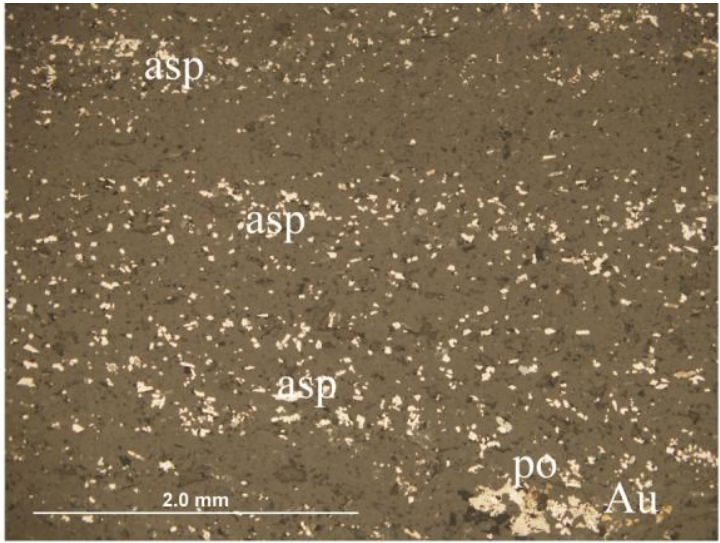

(c)

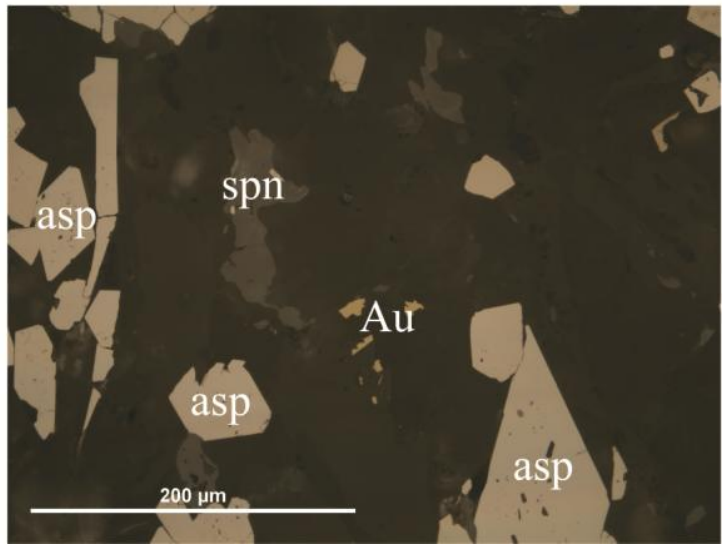

(b)

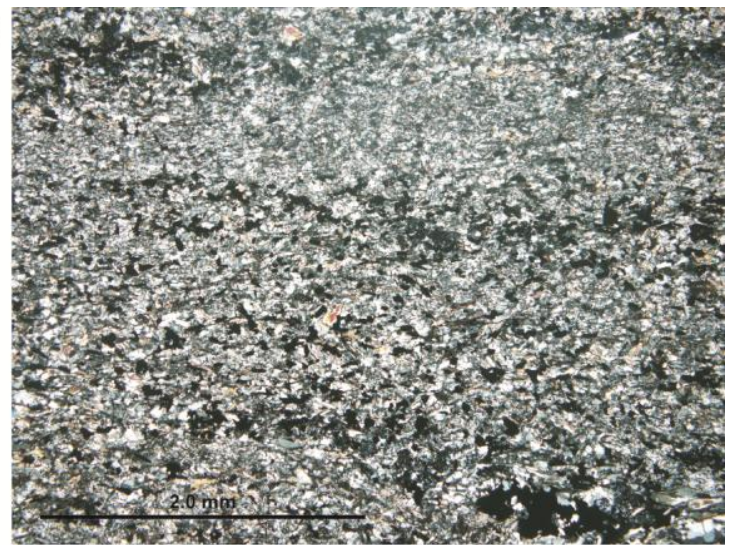

(d)

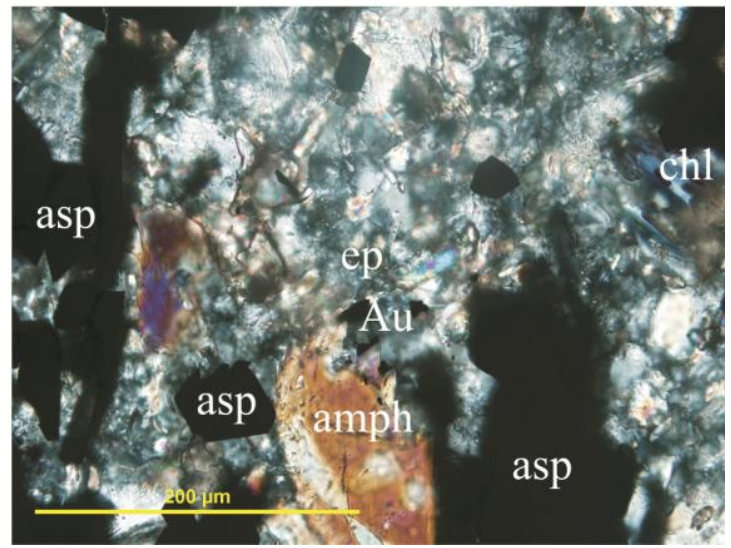

Figure 4.2 Representative photomicrographs of mineralized samples from Plutonic; mineral abbreviations after Kretz (1983); amph = amphibole. (a) Reflected light image of fine-scale laminations in mineralized sample showing disseminated arsenopyrite with late-stage pyrrhotite and Au. Matrix is predominantly quartz, with minor chlorite, biotite and amphibole. (b) As for (a) but crossed-polars. (c) Reflected light image of arsenopyrite in a mineralized sample. Gold is not texturally associated with the sulphide minerals, but hosted in epidote. Other silicates including amphibole, chlorite and sphene are present. (d) As for (c) but under crossed-polarised light. 


\section{Sample descriptions}

MG801: (Pb-isotope model age, arsenopyrite) This sample comes from an early quartz-tourmaline-arsenopyrite-Au vein. The Au is most concentrated near the edges of the vein, infills fractures that cross-cut the tourmaline and some of the arsenopyrite appears to be texturally later than the vein.

MG034: (Rb-Sr, biotite, muscovite; Pb-isotope model age, arsenopyrite, pyrrhotite) This sample is of muscovite-rich lode that is rare within the Mine Mafic Package. The rock has the appearance of crenulated muscovite schist that consists mainly of very fine-grained green muscovite and quartz, with lesser amounts of arsenopyrite, and biotite, tourmaline and pyrrhotite. The arsenopyrite crystals have a random habit; they tend to grow in clusters which radiate out from a central point and over-print the preexisting crenulation. Gold $(15-30 \mathrm{~g} / \mathrm{t})$ is probably mainly hosted within the crystal lattice of arsenopyrite and occurs occasionally as blebs of free Au typically near arsenopyrite crystals, on their grain boundaries, or as inclusions within them.

MG233: (Pb-isotope model age, pyrrhotite) In its mineralogy, this sample is of brown lode, which is the main generation of Au mineralization at Plutonic. The sulfide mineral assemblage is pyrrhotite-dominated (quartz-biotite-chlorite-amphiboletitanite-epidote-pyrrhotite \pm arsenopyrite \pm chalcopyrite \pm scheelite \pm Au). The fine laminations that characterize typical brown lode are lacking, and there is comparatively more textural evidence of deformation, in the form of a well-defined fabric that wraps the pyrrhotite crystals and biotite and chlorite wings on pyrrhotite. Gold ( 400 g/t in this sample), is common as small blebs up to several hundred 
microns across, both disseminated within the silicate groundmass of the sample, and along the edges of the anhedral pyrrhotite crystals.

MG354: ( $\mathrm{Pb}-\mathrm{Pb}$, titanite) This sample is of a thin (mm-scale), late-stage, chloritecarbonate vein with calcite crystals that have their largest dimensions (up to $\sim 1 \mathrm{~cm}$ ) in the plane of the vein. The euhedral to subhedral titanite crystals in this vein are pale pink to orange in color and up to $\sim 3 \mathrm{~mm}$ in length. There is no evidence that this veining is associated with $\mathrm{Au}$ mineralization at this location.

MG039: (Pb-isotope model age, pyrrhotite) This sample is of metamorphosed ultramafic rock on the contact between the metabasaltic Mine Mafic Package and the overlying ultramafic rocks. Large dravite crystals and massive pyrrhotite can occur along this contact, where they are associated with low Au grades, in this sample 2 g/t. The sample consists primarily of acicular actinolite, with Fe-rich chlorite and talc, and minor feldspar and calcite; the pyrrhotite is blocky and massive in hand-sample.

MG025/MG201: (Pb-isotope model age, pyrrhotite) These samples are from a quartzpyrrhotite-chalcopyrite \pm carbonate \pm Au vein that infills one of the large fault zones (up to several meters wide) in the north of the deposit. The fault trends northeastsouthwest and dips towards the north-west at $\sim 50^{\circ}$ and probably has normal displacement. It is interpreted to have formed during the Capricorn Orogeny at $\sim 1830$ Ma (Pirajno et al. 2004; Vickery, 2004). The average Au grade in this structure is $\sim 4.3$ $\mathrm{g} / \mathrm{t}$. 
MG800: (Pb-isotope model age, sphalerite) This sample is of a quartz- carbonategalena-sphalerite \pm Au vein that infills dilational zones in a large fault in the northeastern corner of the deposit. The fault is near-vertical but dips slightly towards the west-north-west. Low Au grades are sometimes associated with this fault.

MG218/MG340: (Pb-isotope model age, Pyrrhotite) These samples come from small, flat-lying $\left(<30^{\circ}\right.$ dip $)$ quartz-carbonate-pyrrhotite-chalcopyrite \pm Au veins that have apparent reverse displacement on them. Carbonate is more abundant than quartz.

MG802: (Pb-isotope model age, Pyrite) In this sample, Au is intergrown with pyrite in a quartz-pyrite vein that cross-cuts brown lode-style mineralization. This is a very rare style of $\mathrm{Au}$ mineralization as pyrite is uncommon and very seldom associated with Au at Plutonic.

MG222/MG224: (Pb-isotope model age, Pyrrhotite) These two samples provide examples of the brown lode mineralization that occurs in an overturned limb of the Mine Mafic Package where deformation is pervasive, and the package is thinner $(\sim 30$ m) than elsewhere. Both samples consist mainly of quartz, carbonate and amphibole, and contain a very strong fabric defined by abundant epidote and chlorite, with lesser biotite, and rare titanite. Pyrrhotite is the dominant sulfide, and arsenopyrite is very rare. The pyrrhotite and Au are late-stage as they wrap the texturally-early amphibole crystals. 


\section{Analytical Methods}

\section{$5.1 \mathrm{Rb}$-Sr dating of biotite and muscovite}

Mica-bearing rock samples were lightly crushed in a steel percussion mortar, sieved, and $15-70 \mathrm{mg}$ separates of biotite and muscovite were prepared for acid digestion by hand picking. Whole rock samples were ground in a tungsten carbide TEMA ring mill until fine and a 50-60 mg sub-sample was digested. The mica and whole rock separates were digested using $\mathrm{HF}^{-} \mathrm{HNO}_{3}$ at $120{ }^{\circ} \mathrm{C}$ in $7 \mathrm{ml}$ Savillex ${ }^{\circledR}$ Teflon ${ }^{\circledR}$ beakers. After complete dissolution, each sample was taken up in $3 \mathrm{M} \mathrm{HNO}_{3}$, and a $0.2 \mathrm{ml}$ aliquot was taken for ${ }^{87} \mathrm{Rb} /{ }^{86} \mathrm{Sr}$ ratio determinations. The $\mathrm{Sr}$ was separated from the remaining solution using conventional anion exchange column chemistry using $3 \mathrm{M}$ $\mathrm{HNO}_{3}$ on $\sim 5 \mathrm{~mm}$ thick Sr-SPEC resin beds in columns each made from a $1 \mathrm{~mL}$ Eppendorf® pipette tip with a frit in it. $\mathrm{Rb} / \mathrm{Sr}$ ratios were measured on an Agilent 7500CS inductively couple plasma mass spectrometer (ICP-MS) using a 1 ppb 1:1 $\mathrm{Rb}: \mathrm{Sr}$ solution as a standard; ${ }^{87} \mathrm{Sr} /{ }^{86} \mathrm{Sr}$ ratios were measured using a Nu Instruments Nu Plasma multi collector ICP-MS using SRM 987 as a standard, both at Victoria University of Wellington, New Zealand. Standards BHVO-2 and BCR-2 were processed through the same sample preparation as the unknown samples and returned ${ }^{87} \mathrm{Sr} /{ }^{86} \mathrm{Sr}=0.703467 \pm 0.000008$ and ${ }^{87} \mathrm{Sr} /{ }^{86} \mathrm{Sr}=0.705029 \pm 0.000008$ respectively; compared with stated values for BHVO-2 of ${ }^{87} \mathrm{Sr} /{ }^{86} \mathrm{Sr}=0.703467 \pm 0.000017$ and ${ }^{87} \mathrm{Sr} /{ }^{86} \mathrm{Sr}=0.705000 \pm 0.000030$.

\subsection{Pb-Pb dating of sphene}

Titanite was analyzed in situ by laser-ablation ICP-MS at Victoria University of Wellington, New Zealand. A rock chip containing titanite was mounted in epoxy with a shard of a homogenous glass reference standard, NIST610, and prepared by 
grinding using wet $400-4000 \mu \mathrm{m}$ grit silicon carbide paper followed by successive lap polishing using $3 \mu \mathrm{m}$ and $1 \mu \mathrm{m}$ diamond suspensions. The titanite crystals were analyzed using an Agilent 7500CS ICP-MS coupled to a New Wave 193 nm (deep UV) solid-state laser ablation system. The titanite was ablated with a static laser beam (35 $\mu \mathrm{m}$ beam diameter, at $5 \mathrm{~Hz}$, at $65 \%$ power), with analyses acquired over $\sim 30 \mathrm{~s}$ periods, or until the laser had ablated through the crystal. The NIST610 standard was used to correct the titanite $\mathrm{Pb}$ isotopic data for instrumental mass bias. The glass standard was analyzed bracketing every five sample analyses. Instrumental mass bias typically drifted $<<0.05 \%$ per atomic mass unit between standard analyses. Lead isotopic data for the titanite samples were corrected using the ${ }^{208} \mathrm{~Pb} /{ }^{206} \mathrm{~Pb}$ ratio measured on the NIST610 standard with respect to the reference value given by Baker et al. (2004) using the exponential mass fractionation law.

\subsection{Pb-isotope model ages}

Samples weighing 7 - $55 \mathrm{mg}$ of either arsenopyrite or pyrrhotite were handpicked under a stereo microscope from crushed samples. Separates were dissolved with $\mathrm{HBr}$, $\mathrm{HF}$ and $\mathrm{HNO}_{3}$ in $7 \mathrm{ml}$ Savillex ${ }^{\circledR}$ Teflon ${ }^{\circledR}$ beakers. Lead was separated from each solution using a conventional $\mathrm{HCl}-\mathrm{HBr}$ anion exchange procedure, with Eppendorf ${ }^{\circledR} 1$ $\mathrm{ml}$ pipette tips as columns and AG1X8 resin. Lead isotope ratios were measured on a $\mathrm{Nu}$ Instruments $\mathrm{Nu}$ Plasma multi-collector (MC) ICP-MS at Victoria University of Wellington, New Zealand, by sample-standard bracketing with SRM981. To document reproducibility of measurements, SRM981 was analyzed five times at the start of each sample run. The average of SRM981 analyses was ${ }^{208} \mathrm{~Pb} /{ }^{204} \mathrm{~Pb}=36.7216$ $\pm 0.0027,{ }^{207} \mathrm{~Pb} /{ }^{204} \mathrm{~Pb}=15.4988 \pm 0.0011,{ }^{206} \mathrm{~Pb} /{ }^{204} \mathrm{~Pb}=16.9402 \pm 0.0011$; compared to stated values of ${ }^{208} \mathrm{~Pb} /{ }^{204} \mathrm{~Pb}=36.7262 \pm 0.0031,{ }^{207} \mathrm{~Pb} /{ }^{204} \mathrm{~Pb}=15.5000 \pm 0.0013$, 
${ }^{206} \mathrm{~Pb} /{ }^{204} \mathrm{~Pb}=16.9416 \pm 0.0013$. Error correlations with respect to $\mathrm{Pb}$-isotope data were not considered, since the errors associated with the model ages are orders of magnitude larger. Varying the $\mathrm{Pb}$-isotope signatures for the oldest model ages $(\sim 2630$ Ma) by the reported error $<0.05 \%$, results in a variation in model age of $\sim 30 \mathrm{kyr}$; an error of this magnitude is negligible compared to the $30-50 \mathrm{Myr}$ error ascribed to $\mathrm{Pb}$-isotope model ages in this study.

\section{Results}

Table 4.1 presents the new $\mathrm{Rb}-\mathrm{Sr}$ age data for both biotite and muscovite separates and whole rock powders from an Au-bearing sample (MG034), from which $\mathrm{Pb}$ isotope model ages for sulfides were also obtained. A three-point isochron age of $2296 \pm 99$ was obtained from two muscovite separates and the whole rock powder. This approach takes advantage of inter-crystal variations in mica $\mathrm{Rb} / \mathrm{Sr}$ ratios to calculate ages, and although it is possible that there could be tiny inclusions of other minerals such as apatite within the mica samples which would affect the measured $\mathrm{Rb} / \mathrm{Sr}$ ratios, none were observed during back-scatter electron imaging and electron microprobe analyses. The two-point (biotite-whole rock) age was $1779 \pm 46 \mathrm{Ma}$.

The $\mathrm{Pb}$ isotopic data and a calculated ${ }^{207} \mathrm{~Pb}-{ }^{206} \mathrm{~Pb}$ age for five titanite crystals from sample MG354 (Table 4.2) yield an age estimate of $1725 \pm 26 \mathrm{Ma}$.

$\mathrm{Pb}$-isotope model ages for ten pyrrhotite separates, three arsenopyrite separates and a sphalerite separate and pyrite separate are presented in Table 4.3 and Fig. 4.3. ${ }^{207} \mathrm{~Pb} /{ }^{206} \mathrm{~Pb}$ model ages are calculated using the Cumming and Richards (1975) Model III for $\mathrm{t}_{7 / 6}$ ages, with Stacey and Kramers (1975) model ages for the same samples 
presented for comparison. Three groups of Cumming and Richards (1975) model ages were obtained; the oldest grouping from pyrrhotite-bearing samples, an arsenopyritebearing sample and a pyrite-bearing sample at 2300 - $2100 \mathrm{Ma}$, with later ages at $\sim 1850 \mathrm{Ma}$, and $\sim 1730$ - 1660 Ma (see Table 4.3). In addition, a blocky arsenopyrite crystal in a quartz vein that contains abundant free Au gave a model age of $2628 \mathrm{Ma}$, but microtextural evidence suggests that two generations of arsenopyrite are present, and that little $\mathrm{Au}$ is associated with the older generation (pers. comm. R. Hough).

Table $4.1{ }^{87} \mathrm{Rb} /{ }^{86} \mathrm{Sr}$ and ${ }^{87} \mathrm{Sr} /{ }^{86} \mathrm{Sr}$ ratios for biotite- and muscovite-bearing samples from Plutonic.

\begin{tabular}{|c|c|c|c|c|c|c|c|}
\hline Sample & Mineral & $\mathrm{Mg} /\left(\mathrm{Mg}+\mathrm{Fe}_{\mathrm{T}}\right)^{1}$ & ${ }^{87} \mathrm{Rb} /{ }^{86} \mathrm{Sr}^{2}$ & ${ }^{87} \mathrm{Sr} /{ }^{86} \mathrm{Sr}^{2}$ & Error $(2 \sigma)$ & Age $(\mathrm{Ma})^{3}$ & Initial ${ }^{87} \mathrm{Sr} /{ }^{86} \mathrm{Sr}$ \\
\hline \multirow[t]{3}{*}{ MG034 } & Muscovite & - & 6.44 & 0.914396 & 0.000032 & $2296 \pm 99$ & $0.7145 \pm 0.0013$ \\
\hline & Muscovite & & 7.40 & 0.941446 & 0.000064 & & \\
\hline & Whole Rock & & 4.08 & 0.833367 & 0.00002 & & \\
\hline \multirow[t]{2}{*}{ MG233 } & Biotite & $0.53-0.56$ & 6.25 & 0.856257 & 0.000018 & $1820 \pm 42$ & $0.6925 \pm 0.0008$ \\
\hline & Whole Rock & & 0.92 & 0.716566 & 0.000008 & & \\
\hline \multirow[t]{2}{*}{ MG034 } & Biotite & $0.77-0.79$ & 17.90 & 1.186878 & 0.000016 & $1779 \pm 46$ & $0.7291 \pm 0.0037$ \\
\hline & Whole Rock & & 4.08 & 0.833367 & 0.00002 & & \\
\hline $\mathrm{BCR}^{4}$ & & & & 0.705029 & 0.000008 & & \\
\hline BHVO-2 $2^{5}$ & & & & 0.703467 & 0.000008 & & \\
\hline
\end{tabular}

${ }^{1}$ Phlogopite $\left(\mathrm{Mg} /\left(\mathrm{Mg}+\mathrm{Fe}_{\mathrm{T}}\right)\right)$ composition is shown where relevant as determined by electron probe microanalyses.

${ }^{2}$ Error of $1 \%$ is attributed to ${ }^{87} \mathrm{Rb} /{ }^{86} \mathrm{Sr}$ ratios and $2 \sigma$ error as stated for ${ }^{87} \mathrm{Sr} /{ }^{86} \mathrm{Sr}$ ratios.

${ }^{3}$ Isochron ages were calculated using a ${ }^{87} \mathrm{Rb}$ decay constant of $1.42 \times 10^{11} \mathrm{yr}^{-1}$ (Steiger and Jäger, 1977).

${ }^{4} \mathrm{BCR}-2{ }^{87} \mathrm{Sr} /{ }^{86} \mathrm{Sr}=0.705000 \pm 0.000030$.

${ }^{5} \mathrm{BHVO}-2{ }^{87} \mathrm{Sr} /{ }^{86} \mathrm{Sr}=0.703467 \pm 0.000017$.

Table 4.2 $\mathrm{Pb}$-isotope ratios for sphene in a late-stage chlorite-carbonate vein from Plutonic.

\begin{tabular}{ccccc}
\hline \hline $\begin{array}{c}\text { Sphene } \\
\text { Crystal }\end{array}$ & $\begin{array}{c}{ }^{206} \mathrm{~Pb} /{ }^{204} \mathrm{~Pb} \\
\text { Raw }\end{array}$ & $\begin{array}{c}{ }^{207} \mathrm{~Pb} /{ }^{206} \mathrm{~Pb} \\
\text { Raw }\end{array}$ & $\begin{array}{c}{ }^{207} \mathbf{P b} /{ }^{206} \mathrm{~Pb}^{1} \\
\text { NIST610 corrected }\end{array}$ & $\begin{array}{c}{ }^{207} \mathbf{P b} /{ }^{206} \mathrm{~Pb}^{2} \\
\text { Common Pb corrected }\end{array}$ \\
\hline MG354(1) & 270.76 & 0.15607 & 0.15661 & 0.10597 \\
MG354(2) & 174.27 & 0.18267 & 0.18331 & 0.1045 \\
MG354(3) & 354.71 & 0.14354 & 0.14404 & 0.10536 \\
MG354(8) & 335.46 & 0.146 & 0.14651 & 0.10563 \\
MG354(9) & 407.03 & 0.13965 & 0.14014 & 0.10648 \\
\hline & & Average & 0.10559 \\
& & Age & $1725 \pm 26 \mathrm{Ma}$ \\
\hline \hline
\end{tabular}

\footnotetext{
${ }^{1207} \mathrm{~Pb} /{ }^{206} \mathrm{~Pb}$ ratios are corrected for fractionation using standard NIST610.

${ }^{2}$ Common $\mathrm{Pb}$ correction calculated using counts ${ }^{204} \mathrm{~Pb}$ measured and ${ }^{206} \mathrm{~Pb} /{ }^{204} \mathrm{~Pb}=15.5 ;{ }^{207} \mathrm{~Pb} /{ }^{204} \mathrm{~Pb}=15.5$ (Cumming and Richards, 1975).
} 
Table 4.3 Lead isotope compositions of sulfides from samples from Plutonic.

\begin{tabular}{lclcccc}
\hline \hline Sample & Mineral & \multicolumn{1}{c}{ Description } & ${ }^{208} \mathrm{~Pb} /{ }^{204} \mathrm{~Pb}^{2}$ & ${ }^{207} \mathrm{~Pb} /{ }^{204} \mathrm{~Pb}$ & ${ }^{206} \mathrm{~Pb} /{ }^{204} \mathrm{~Pb}$ & Model age $(\mathrm{Ma})^{3}$ \\
\hline MG801 & asp & Qtz-tur-asp-Au vein & 33.646 & 14.856 & 13.851 & 2,628 \\
MG802 & py & Qtz-py-Au vein & 34.264 & 14.987 & 14.398 & 2,321 \\
MG340 & po & Qtz-cal-po vein & 34.147 & 15.068 & 14.553 & 2,273 \\
MG233 & po & Brown lode & 34.242 & 15.02 & 14.533 & 2,250 \\
MG222 & po & Brown lode & 34.346 & 15.046 & 14.589 & 2,235 \\
MG218 & po & Qtz-cal-po vein & 34.475 & 15.096 & 14.724 & 2,174 \\
MG224 & po & Brown lode & 34.513 & 15.146 & 14.873 & 2,110 \\
MG034 & asp & Green Mica Lode & 34.704 & 15.081 & 14.778 & 2,124 \\
MG034 & asp & Green Mica Lode & 35.071 & 15.101 & 14.922 & 2,039 \\
MG201 & po & Bintang Fault & 34.743 & 15.217 & 15.17 & 1,962 \\
MG034 & po & Green Mica Lode & 34.895 & 15.157 & 15.16 & 1,919 \\
MG025 & po & Bintang Fault & 35.136 & 15.277 & 15.433 & 1,833 \\
MG800 & sp & Qtz-sp vein & 35.468 & 15.376 & 15.711 & 1,730 \\
MG039 & po & Ultramafic & 36.339 & 15.361 & 16.015 & 1,516 \\
\hline \hline
\end{tabular}

${ }^{1}$ All mineral abbreviations after Kretz (1983).

${ }^{2} \mathrm{~Pb}$-isotope model ages calculated with multi-stage $\mathrm{t}_{7 / 6}$ evolution model of Cumming and Richards (1975) and have an error of \pm 30 Myr (Vielreicher et al., 2002).

${ }^{3}$ Ratios are fractionation corrected (after Baker et al., 2004); errors on $\mathrm{Pb}$ isotope analyses are $<0.05 \%$.

\section{Discussion}

Dating methods that do not directly analyze the Au-bearing phase rely on the assumption that the mineral that is dated crystallized, or was reset during the $\mathrm{Au}$ mineralization event. Geological field evidence such as cross-cutting relationships and petrographic textural evidence are required to support the assumption that the mineral dated grew or was isotopically reset at the same time as Au mineralization occurred. At Plutonic none of the commonly-used silicate or phosphate geochronometers are unambiguously associated with Au. Instead, Au is associated with sulfides, either in textural equilibrium with the sulfides (e.g. pyrrhotite) or contained within its crystal lattice (e.g. arsenopyrite). 


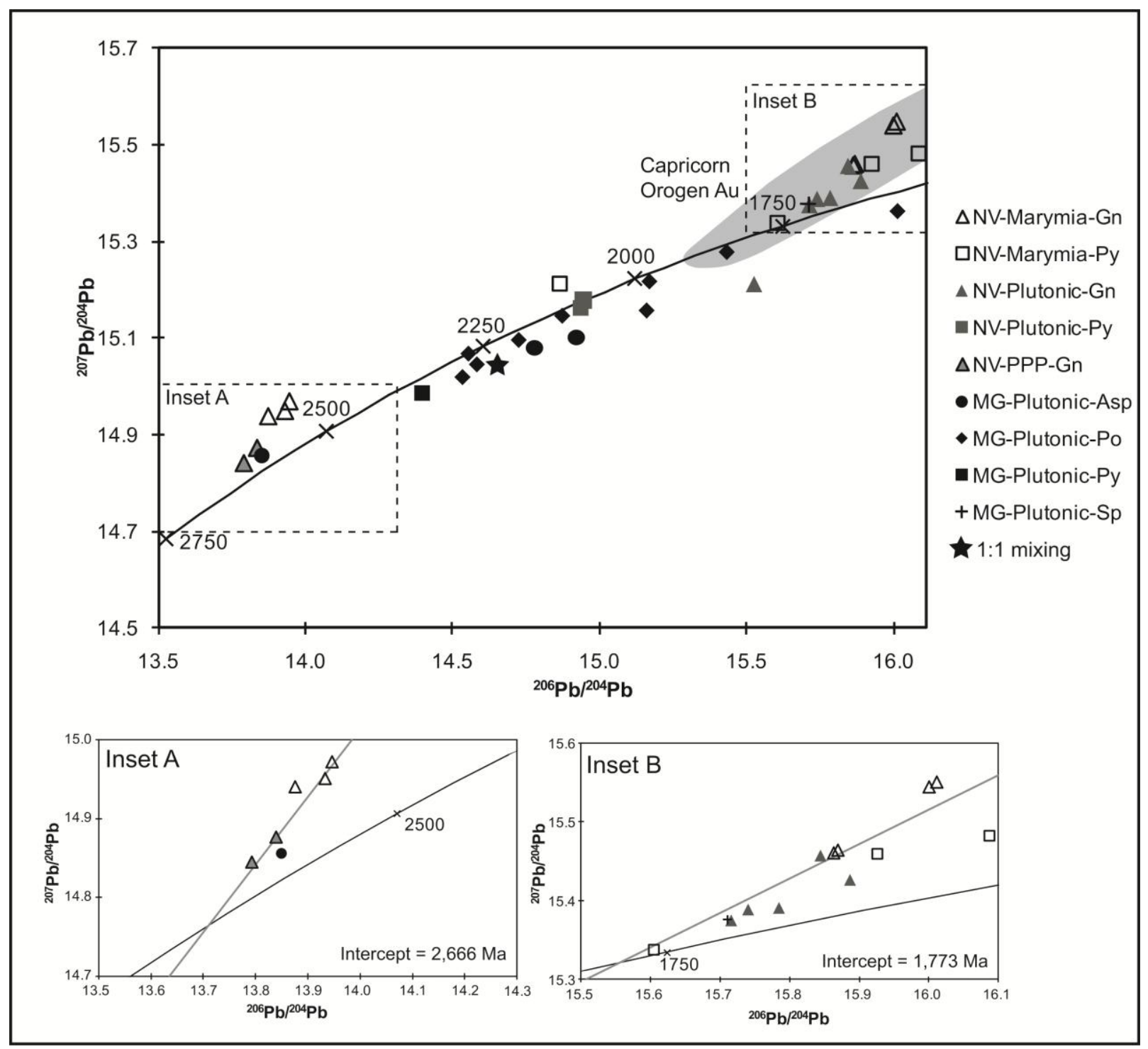

Figure 4.4 Conchordia diagram showing ${ }^{206} \mathrm{~Pb} /{ }^{204} \mathrm{~Pb}$ and ${ }^{207} \mathrm{~Pb} /{ }^{204} \mathrm{~Pb}$ isotope ratios for sulfide minerals from the Plutonic Well Greenstone Belt from this study (MG), and Vielreicher et al. (2002) (NV). Mineral abbreviations after Kretz (1983). Grey shaded field represents Pb-isotope ratios from the Peak Hill area (after Vielreicher and McNaughton, 2002, and references therein).The star indicates a theoretical $\mathrm{Pb}$-isotope composition derived from approximately equal proportions of sulfides that crystallized in two different events at $\sim 2650$ Ma and $\sim 1720$ Ma. Location abbreviations: Marymia $=$ Marymia Gold Mine, PPP $=$ Triple $\mathrm{P}$ deposit, Plutonic $=$ Plutonic Gold Mine.

\subsection{Peak metamorphic conditions}

The results of a limited amount of U-Pb dating of zircon date peak metamorphism within the PWGB at 2660 - 2630 Ma (McMillan 1996 (belt-wide); Vielreicher and

McNaughton 2002 (belt-wide); Vickery 2004 (Plutonic area)). This is consistent with 
the timing of metamorphism in the Yilgarn Craton (e.g. Groves et al. 2000). In our work, we found no new samples that would enable us to further constrain the timing of peak metamorphism at Plutonic. Thus, the focus of this study is was to better constrain the timing of $\mathrm{Au}$ mineralization.

\subsection{Cooling history}

Peak metamorphism reached temperatures of $\sim 600{ }^{\circ} \mathrm{C}$ (Gazley et al. $2011 \mathrm{~b}$ (Chapter 3)). This is higher than the closure temperatures $\left(T_{c}\right)$ for the $\mathrm{Rb}-\mathrm{Sr}$ system in micas, so the $\mathrm{Rb}-\mathrm{Sr}$ ages will record cooling or resetting following the metamorphic peak. Depending on grain size, muscovite has a closure temperature of $500-550{ }^{\circ} \mathrm{C}$ (Willigers et al. 2004). As the muscovite within the studied sample is rather fine grained $(\sim 200 \mu \mathrm{m})$, it is probable that the closure temperatures were at the lower end of this range, and that the temperature at $2296 \pm 99 \mathrm{Ma}$ was near $500{ }^{\circ} \mathrm{C}$. The closure temperature for the $\mathrm{Rb}-\mathrm{Sr}$ system in biotite $\left(\sim 400-450{ }^{\circ} \mathrm{C}\right)$ is sensitive to both grain size and composition, with higher phlogopite $\left(\mathrm{Mg} /\left(\mathrm{Mg}+\mathrm{Fe}_{\mathrm{T}}\right)\right)$ contents being associated with higher closure temperatures (Willigers et al. 2004; Vry and Baker 2006). As the biotite in MG034 is very fine-grained, the biotite age of $1779 \pm 46 \mathrm{Ma}$ most likely represents closure of the $\mathrm{Rb}-\mathrm{Sr}$ system during cooling through temperatures $\sim 400{ }^{\circ} \mathrm{C}$.

If the micas were not reset at temperatures above $\sim 500{ }^{\circ} \mathrm{C}$ at some time after the regional metamorphic peak, then the new $\mathrm{Rb}-\mathrm{Sr}$ ages could be indicative of extremely slow cooling from peak temperatures of $\sim 600^{\circ} \mathrm{C}$ at $\sim 2630$ Ma to $\sim 400{ }^{\circ} \mathrm{C}$ at $1779 \pm$ $46 \mathrm{Ma}$, giving an average cooling rate of $0.23{ }^{\circ} \mathrm{C} / \mathrm{Myr}$ for $\sim 850 \mathrm{Myr}$. Such a very slow cooling rate (cf. rates in slow-cooled deep-crustal granulites of $1-2{ }^{\circ} \mathrm{C} / \mathrm{Myr}$ or less; 
e.g. Ashwal et al. 1999), if confirmed, might provide support for a gravity-driven tectonic model involving sinking of a large body of greenstone rock into a predominantly granitic crust (Rey et al. 2003; see also Gazley et al. 2011b (Chapter 3)), where the rocks could remain until exhumed by a later event, such as the collision between the Pilbara and Yilgarn cratons in the $~ 1830$ Ma Capricorn Orogeny (Pirajno et al. 2004).

\subsection{Timing of Au mineralization}

The age of sulfides as determined by $\mathrm{Pb}$-isotope model ages is very dependent on the model chosen. We prefer the model of Cumming and Richards (1975), as this model gives oldest ages that are around the age of peak metamorphism at $\sim 2660-2630 \mathrm{Ma}$, and another age population $\sim 1730-1660 \mathrm{Ma}$, around the age of a metasomatic event dated by $\mathrm{Pb}-\mathrm{Pb}$ and $\mathrm{U}-\mathrm{Pb}$ dating at $\sim 1720 \mathrm{Ma}$ (Vielreicher and McNaughton 2002; this study). The Stacey and Kramers (1975) model returns ages for the oldest sulfides of $\sim 2800 \mathrm{Ma}$ (Table 4.4) that are older than the probable age of the host-rocks.

Since only very minor galena and pyrite are present at Plutonic, the choice of minerals that can be analyzed to constrain the timing of Au deposition is effectively restricted to pyrrhotite, arsenopyrite, and rare pyrite and sphalerite. Arsenopyrite and pyrrhotite can sometimes reliably preserve initial $\mathrm{Pb}$-isotope compositions ( $\mathrm{McNaughton}$ and Groves, 1996), even though their $\mathrm{Pb}$-isotope ratios may not plot on the mantle growth curve, due to the tendency of these minerals to incorporate some $\mathrm{U}$ and $\mathrm{Th}$ into their crystal structures (McNaughton 1987). In sulfides other than galena or pyrite, the sample with the least radiogenic $\mathrm{Pb}$-isotope composition in a suite of samples from the same mineralization event is most likely to represent the best estimate for the 
initial Pb (Ho et al. 1994; McNaughton and Groves 1996). McNaughton and Dahl (1987) showed that $\mathrm{Pb}$-isotope model ages for syngenetic galena and Fe-sulfides from elsewhere in the Yilgarn Craton possibly over-estimated the age of formation by up to $\sim 70$ Myr. For our samples, the ages derived from the projection of arrays back to the growth curve are $2666 \mathrm{Ma}$ and $1773 \mathrm{Ma}$. These ages are consistent with the individual $\mathrm{Pb}$-isotope model ages for sulfide minerals of 2630 Ma and 1730 - 1660 Ma since these individual ages have an error of \pm 50 Myr (Cumming and Richards 1975).

Data from different sulfide minerals will reflect natural variations in $\mathrm{Pb}$-isotope ratios and subsequent re-equilibration of the sulfides, even if the sulfides all crystallized during the same mineralization event (cf. Ho et al. 1994). Our data has been obtained from different sulfide minerals, collected from within different lithologies, from different parts of an Au-mineralizing system, and so are likely to have natural variation in their $\mathrm{Pb}$-isotope compositions. Closure temperatures for $\mathrm{Pb}$ diffusion in sulfides are not known, but major elements in sulfides, especially in pyrrhotite, are widely regarded as being susceptible to low-temperature re-equilibration (e.g. Hagemann et al. 1998; Cherniak 2010). Even so, the observation that many of the sulfide $\mathrm{Pb}$-isotope model ages from Plutonic cluster at ages ( $2200 \mathrm{Ma})$ that are older than the $\mathrm{Rb}-\mathrm{Sr}$ ages for biotite $\left(T_{c} \sim 450-400{ }^{\circ} \mathrm{C}\right.$; e.g. Willigers et al. 2004), in one case from the same sample, suggests that the $T_{c}$ for $\mathrm{Pb}$ diffusion in both pyrrhotite and arsenopyrite may be $400{ }^{\circ} \mathrm{C}$ or higher. It is possible that the $T_{c}$ for $\mathrm{Pb}$ diffusion in arsenopyrite was even higher, as the texturally older generation of arsenopyrite in MG801 returned a Pb-isotope model age of $2628 \mathrm{Ma}$, and the inferred metamorphic temperatures at that time were near $600{ }^{\circ} \mathrm{C}$ (at $2660-2630 \mathrm{Ma}$ ) the regional maximum (Vielreicher and McNaughton 2002; Gazley et al. 2011b (Chapter 3)). The 
available evidence from both here and the literature, indicates that $\mathrm{Pb}$-isotope model ages for sulfides from mineral deposits can compare favorably to results obtained using conventional geochronometers (e.g. McNaughton and Dahl 1987; Ho et al. 1994; McNaughton and Groves 1996).

Table 4.4 presents $\mathrm{Pb}$-isotope ratio data for sulfides from the PWGB (Vielreicher et al. (2002), and references therein), which help to constrain the timing of $\mathrm{Au}$ mineralization. These data show three main clusters of $\mathrm{Pb}$-isotope model ages in the PWGB at $\sim 2650 \mathrm{Ma}, \sim 2100 \mathrm{Ma}$, and $\sim 1730-1660 \mathrm{Ma}$. Previous workers interpreted the main Au-mineralization event at Plutonic to be syn- to slightly post-peak metamorphism (2660 - 2630 Ma; e.g. Rowe et al. 2002; Vielreicher et al. 2002; Vickery 2004), although the only Pb-isotope model ages of this age are from the Triple P and Marymia deposits - see Fig. 4.1 for location (e.g. Vielreicher et al. 2002). It should be noted that Vielreicher et al.'s (2002) data was determined by thermal ionization mass spectrometry (TIMS), whereas the data in the present study were collected on a MC-ICP-MS. Given that Vielreicher et al.'s (2002) data were measured in the early- to mid-1990s, it is likely that a different value for SRM981 was applied to correct the data to that applied in this study (e.g. Baker et al. 2004). Furthermore, TIMS data for the same samples are not consistent with that collected by MC-ICP-MS (e.g. White et al. 2000), thus there is a minor systematic error that exists between that dataset and the one presented here. However, this error is less than that of the error ascribed to Vielreicher et al.'s (2002) Pb-isotope data of $\pm 0.15 \%$, and has thus been ignored here. 
The largest cluster of Pb-isotope model ages ( 2200 Ma; this study; Vielreicher et al. 2002; and references therein; Tables 4.3 and 4.4) is from sulfides that either host or are in textural equilibrium with Au. Free Au typically appears to be texturally-late, and thus could have been deposited during either the $2200 \mathrm{Ma}$ or $1730-1660 \mathrm{Ma}$ mineralization events. These data support the interpretation that the early $\sim 2650 \mathrm{Ma}$ Au-mineralization event was either not strongly developed in the Plutonic region, or was overprinted by later $\mathrm{Au}$ mineralization to such an extent that the $\sim 2650 \mathrm{Ma} \mathrm{Pb}$ isotope signature can no longer be discerned. What may have led to multiple generations of Au being deposited at Plutonic is uncertain, but it is clear that much of the Au mineralization occurred more recently than previously thought.

The new results from Au-bearing samples from Plutonic predominantly record Paleoproterozoic ages in the range 2400 - $2000 \mathrm{Ma}$ (Table 4.3). The new results complement and reinforce earlier evidence from $\mathrm{Pb}$-isotope model ages for pyrite from the region (Table 4.4). The Paleoproterozoic ages post-date the inferred timing of amphibolite-facies peak metamorphism at $\sim 2660-2630$ Ma by more than $\sim 300$ Myr, and plot between a Yilgarn-like cluster of ages $2650 \mathrm{Ma}$, and younger ages attributable to effects of the 1830 - 1780 Ma Capricorn Orogeny. Taken together, all the available evidence supports the interpretation that a major episode of $\mathrm{Au}$ mineralization affected the Plutonic area and adjacent parts of the Marymia Inlier in Paleoproterozoic time.

If a significant episode of Au mineralization and new mineral growth affected the Marymia Inlier, and by inference other areas along northern margin of the Yilgarn Craton in Paleoproterozoic time, the affected areas would represent a potential source 
for detritus of this age in adjacent basins. Halilovic et al. (2004) report detrital zircon age populations with major peaks in at $\sim 2250 \mathrm{Ma}$ and $~ 2000 \mathrm{Ma}$ in the Yelma Formation in the Earaheedy Basin (part of the Earaheedy Group in Fig. 4.1), to the southeast of the Marymia Inlier. The possible source areas for these sediments have in the past been considered somewhat enigmatic, as there are very few known source areas with appropriate ages in Western Australia (Halilovic et al. 2004). The age peaks overlap those from the southern part of the Gascoyne Complex (located to the northwest of Plutonic), and the sediments are interpreted to have been derived from a source generally to the west (Halilovic et al. 2004). Our evidence suggests that the accretion of the Gascoyne Complex to the northern margin of the Yilgarn Craton in Paleoproterozoic time was part of a more extensive tectonic episode that also affected the Marymia Inlier and potentially led to Au mineralization there.

The $\sim 2200 \mathrm{Ma}$ age for Au mineralization also correlates with the age of mafic magmatism associated with the Opthalmian Orogeny in the southern Hamersley Province of the Pilbara Craton at 2215 - 2145 Ma, with slab break-off and sub-crustal melting at $2210 \mathrm{Ma}$ (Martin and Morris 2010). Selway et al. (2009) note that the Capricorn Orogen has been affected by numerous thermal events including the Opthalmian Orogeny; thus, it is possible that Au mineralization at Plutonic could be associated with this significant geological event.

It is also conceivable that an apparent age of $\sim 2200$ Ma could be obtained if a sulfide sample contained approximately equal proportions of sulfides that crystallized in two different events (e.g. 2650 Ma and $\sim 1720 \mathrm{Ma}$ ), and if the ages from the earlier event were not reset (as indicated by the star on Fig. 4.3). However, on the basis of observed 
textures, most of the samples that record the $\sim 2200$ Ma event contain only a single generation of sulfides, making a mixing hypothesis unlikely.

Younger Pb-isotope model ages of $1962 \mathrm{Ma}$ and $1833 \mathrm{Ma}$ were obtained from pyrrhotite in sample MG025 from the quartz-pyrrhotite-chalcopyrite \pm carbonate $\pm \mathrm{Au}$ vein that infills a large fault zone. These results substantiate the interpretation of Vickery (2004) that a later Au mineralization event affected the rocks of the Plutonic area during the Capricorn Orogeny ( $1830 \mathrm{Ma}$; Pirajno et al. 2004), and that this fault may have been an early-formed structure reactivated during the Capricorn Orogeny (pers. comm. J. Miller).

The $\mathrm{Pb}$-isotope ratios for sulfide minerals and hence the $\mathrm{Pb}$-isotope model ages of inferred Proterozoic Au mineralization at Plutonic differ from those obtained at other deposits in the PWGB and may provide a method for identifying other mineral deposits with a similar genesis (e.g. Delevaux et al. 1967). Carr et al. (1995), with no implication of the size of the $\mathrm{Au}$ endowment, noted that if $\mathrm{Pb}$-isotope ratios from a new prospect or deposit in a particular metallogenic domain can be matched with the $\mathrm{Pb}$-isotope ratios of a known, significant deposit, then the probability is increased that the new prospect or deposit will also be a viable one. By applying this idea to further exploration in the wider region, it may be possible to relate other deposits to the Plutonic Au-mineralizing system.

\subsection{Late-stage metasomatism}

Our new ${ }^{207} \mathrm{~Pb}-{ }^{206} \mathrm{~Pb}$ age determination for vein-hosted titanite records an age of 1725 $\pm 26 \mathrm{Ma}$ (Table 4.2). Based on the biotite $\mathrm{Rb}$-Sr results described earlier (showing 
cooling through $\sim 400{ }^{\circ} \mathrm{C}$ at $1779 \pm 46 \mathrm{Ma}$ ), the temperature of the host rock into which the chlorite-carbonate-titanite vein was emplaced was likely to be $\sim 400{ }^{\circ} \mathrm{C}$ or cooler. As the $T_{c}$ for $\mathrm{Pb}$ diffusion in titanite is considerably higher than that $\left(\sim 600{ }^{\circ} \mathrm{C}\right.$, Willigers et al. 2002), we interpret the age as dating the crystallization of the titanite and the emplacement of the vein.

Table 4.4 Lead isotope compositions of sulfides from the PWGB. ${ }^{1}$

\begin{tabular}{cccccc}
\hline \hline Sample & Mineral ${ }^{2}$ & ${ }^{208} \mathrm{~Pb} /{ }^{204} \mathrm{~Pb}^{3}$ & ${ }^{207} \mathrm{~Pb} /{ }^{204} \mathrm{~Pb}$ & ${ }^{206} \mathrm{~Pb} /{ }^{204} \mathrm{~Pb}$ & Model age $(\mathrm{Ma})^{4}$ \\
\hline Marymia & gn & 33.639 & 14.937 & 13.874 & 2,670 \\
Marymia & gn & 33.762 & 14.968 & 13.946 & 2,639 \\
Marymia & gn & 33.684 & 14.948 & 13.931 & 2,636 \\
Marymia & gn & 34.861 & 15.458 & 15.863 & 1,698 \\
Marymia & gn & 34.964 & 15.461 & 15.869 & 1,697 \\
Marymia & gn & 35.828 & 15.549 & 16.011 & 1,677 \\
Marymia & gn & 35.813 & 15.541 & 16.0058 \\
Marymia & py & 34.395 & 15.214 & 14.865 & 2,169 \\
Marymia & py & 35.396 & 15.337 & 15.605 & 1,767 \\
Marymia & py & 35.656 & 15.459 & 15.926 & 1,658 \\
Marymia & py & 35.570 & 15.482 & 16.087 & 1,573 \\
Triple P & gn & 33.603 & 14.840 & 13.792 & 2,660 \\
Triple P & gn & 33.677 & 14.872 & 13.837 & 2,650 \\
Plutonic & gn & 35.465 & 15.374 & 15.714 & 1,726 \\
Plutonic & gn & 35.495 & 15.387 & 15.740 & 1,720 \\
Plutonic & gn & 34.919 & 15.455 & 15.844 & 1,708 \\
Plutonic & gn & 35.470 & 15.389 & 15.784 & 1,692 \\
Plutonic & gn & 35.643 & 15.424 & 15.887 & 2,079 \\
Plutonic & py & 34.853 & 15.163 & 14.937 & 2,085 \\
Plutonic & py & 34.377 & 15.178 & 14.945 & 1,654 \\
\hline \hline Anayses & & & & \\
\end{tabular}

\footnotetext{
${ }^{1}$ Analyses from Vielreicher et al. (2002) and references therein. Data are reproduced here for convenience.

${ }^{2}$ gn = galena; py = pyrite.

${ }^{3}$ Errors on $\mathrm{Pb}$ isotope analyses are $\pm 0.15 \%$.

${ }^{4} \mathrm{~Pb}$-isotope model ages calculated with multi-stage $\mathrm{t}_{7 / 6}$ evolution model of Cumming and Richards (1975) and have an error of \pm 30 Myr (Vielreicher et al., 2002).
}

It is likely that our titanite ${ }^{207} \mathrm{~Pb}^{206} \mathrm{~Pb}$ age records the same metasomatic event that was dated at $1719 \pm 14 \mathrm{Ma}$ by $\mathrm{U}-\mathrm{Pb}$ ages of zircon overgrowths in a sample from Marymia (Vielreicher and McNaughton 2002). Based on the strong temporal 
relationship between the $\sim 1720$ Ma metasomatic event (recorded in unmineralized samples) and the 1730 - $1660 \mathrm{Ma}$ Au-mineralizing event, it is probable both represent the same event, and that the effects were relatively widespread throughout the PWGB.

\section{Conclusions}

The new geochronology data that we have presented in this paper, coupled with that previously available (e.g. McMillan 1996; Vielreicher and McNaughton 2002; Vielreicher et al. 2002; Vickery 2004), record a geological history with some events correlating to other Au deposits within the PWGB, and to those elsewhere in the Yilgarn Craton, and other events only being recognised at Plutonic.

The rocks of the Plutonic area were affected by amphibolite facies metamorphism with high pressures $\left(\geq 8 \mathrm{kbar}\right.$ at $\left.\sim 600^{\circ} \mathrm{C}\right)$ at $\sim 2660-2630 \mathrm{Ma}$. After this, there were a number of Au-mineralization events. $\mathrm{Rb}-\mathrm{Sr}$ data from a biotite from Plutonic possibly indicates that the metamorphism was followed by a protracted period of slow cooling. Alternatively, the biotite data may reflect some combination of resetting, probably related to metasomatic events associated with $\mathrm{Au}$ mineralization at $\sim 2200 \mathrm{Ma}$, or with the Capricorn Orogeny at $\sim 1830 \mathrm{Ma}$, and cooling. A further metasomatic event that occurred at $\sim 1720$ Ma which is dated by both $\mathrm{U}-\mathrm{Pb}$ dating of zircon overgrowths (McMillan 1996; Vielreicher and McNaughton 2002), and $\mathrm{Pb}-\mathrm{Pb}$ dating of titanite (this study). This metasomatic event was probably associated with Au mineralization, as the $\mathrm{Pb}$-isotope ages for the final Au-mineralizing event range from $1730-1660$ Ma. 
Four Au-mineralizing events are identified at Plutonic ( 2650 Ma, 2200 Ma, 1850 Ma, and $1730-1660 \mathrm{Ma})$. A major Au-mineralizing event is inferred to have occurred at $2200 \mathrm{Ma}$, some 400 Myr later than previously expected for Plutonic, the PWGB, or the Yilgarn Craton (e.g. McMillan 1996; Groves et al. 2000; Vielreicher et al. 2002; Vielreicher et al. 2010). There is little direct evidence for what may have driven $\mathrm{Au}$ mineralization at this age in the Plutonic area, but Au deposition at Plutonic was long-lived, with Au being concentrated in the same area for $\sim 1000 \mathrm{Myr}$ (between $\sim 2650 \mathrm{Ma}$ and $\sim 1660 \mathrm{Ma}$ ). The processes responsible for this Au mineralization warrant more research, as improved understanding could lead to the identification of Au mineralization in areas that were previously considered to be unprospective for $\mathrm{Au}$, simply because of their age. 


\section{References}

Ashwal LD, Tucker RD, Zinner EK (1999) Slow cooling of deep crustal granulites and Pb-loss in zircon. Geochim Cosmochim Acta 63:2839-2851.

Bagas L (1999) Early tectonic history of the Marymia Inlier and correlation with the Archaean Yilgarn Craton, Western Australia. Aust J Earth Sci 46:115-125.

Baker JA, Peate DW, Waight TE, Meyzen C (2004) High-precision Pb isotopic analysis of standards and samples using thallium and a lead double spike with a double focusing MC-ICPMS. Chem Geol 211:275-303.

Carr GR, Dean JA, Suppel DW, Heithersay PS (1995) Precise lead isotope fingerprinting of hydrothermal activity associated with Ordovician to Carboniferous metallogenice in the Lachlan Fold Belt of New South Wales. Econ Geol 90:1467-1505.

Cawood P, Tyler IM (2004) Assembling and reactivating the Proterozoic Capricorn Orogen: lithotectonic elements, orogenies, and significance. Precambrian Res 128:201-218.

Cherniak DJ (2010) Diffusion in carbonate, fluorite, sulfide minerals, and diamond. Rev Mineral Geochem 72:871-897.

Cumming GL, Richards JR (1975) Ore lead isotope ratios in a continuously changing earth. Earth Planet Sci Lett 28:155-171.

Delevaux MH, Doe BR, Brown GF (1967) Preliminary lead isotope investigations of brine from the Red Sea, galena from the Kingdom of Saudi Arabia and galena from United Arab Republic (Egypt). Earth Planet Sci Lett 3:139-144.

Fallon M, Porwal A, Guj P (2010) Prospectivity analysis of the Plutonic Marymia Greenstone Belt, Western Australia. Ore Geol Rev 38:208-218. 
Gazley MF, Vry JK, du Plessis E, Handler MR (2011a) Application of hand-held Xray fluorescence analyses to Metabasalt Stratigraphy, Plutonic Gold Mine, Western Australia. J Geochem Explor 110:74-80.

Gazley MF, Vry JK, Boorman JC (2011b) $P-T$ evolution in greenstone belt mafic amphibolites: an example from Plutonic Gold Mine, Marymia Inlier, Western Australia. J Metamorph Geol 29:685-697.

Groves DI, Goldfarb RJ, Gebre-Mariam M, Hagemann SG, Robert F (1998) Orogenic gold deposits: a proposed classification in the context of their crustal distribution and relationship to other deposit types. Ore Geol Rev 13:7-27.

Groves DI, Goldfarb RJ, Knox-Robinson CM, Ojala J, Gardoll S, Yun GY, Holyland P (2000) Late-kinematic timing of orogenic gold deposits and significance for computer based exploration techniques with emphasis on the Yilgarn Block, Western Australia. Ore Geol Rev 17:1-38

Hagemann SG, Brown PE, Ridley J, Stern P, Fournelle J (1998) Ore petrology, chemistry and timing of electrum in the Archean hypozonal Transvaal lode gold deposit, Western Australia. Econ Geol 93:271-291.

Halilovic J, Cawood PA, Jones JA, Pirajno F, Nemchin AA (2004) Provence of the Earaheedy Basin: implications for the assembly of the Western Australia Craton. Precambrian Res 128: 343-366.

Ho SE, McNaughton NJ, Groves DI (1994) Criteria for determining initial Pb-isotope compositions of pyrite in Archaean lode-gold deposits: a case study at Victory, Kambalda, Western Australia. Chem Geol 111:57-84.

Kretz R (1983) Symbols for rock-forming minerals. Am Mineral 68:277-279. 
Martin DMcB, Morris PA (2010) Tectonic setting and regional implications of ca. 2.2 Ga mafic magmatism in the southern Hamersley Province, Western Australia. Aust J Earth Sci 57:911-931.

McMillan NM (1996) Late-Archaean, syn-amphibolite facies, lode-gold deposits overprinted by Paleoproterozoic deformation, metasomatism and hydrothermal activity at Marymia, Western Australia. PhD Dissertation University of Western Australia.

McNaughton NJ (1987) Lead-Isotope Systematics for Archaean Sulfide Studies. In: Ho SE, Groves DI, (eds), Recent Advances in Understanding Precambrian Gold Deposits. Geology Department and University Extension, University of Western Australia, Publication 11.

McNaughton NJ, Groves DI (1996) A review of Pb-isotope constraints of the genesis of lode-gold deposits in the Yilgarn Craton, Western Australia. J Roy Soc West Aust 28:123-129.

McNaughton NJ, Dahl N (1987) A geochronological framework for gold mineralization in the Yilgarn Block, Western Australia. In: Ho SE, Groves DI (eds), Recent Advances in Understanding Precambrian Gold Deposits. Geology Department and University Extension, University of Western Australia, Publication 11.

Morgan R (2004) The Lithogeochemical Characteristics of the Mine Mafic Within Zone 19 (The Baltic), Plutonic Gold Mine, Western Australia. Honours Dissertation, Curtin University of Technology.

Pirajno F, Jones JA, Hocking RM, Halilovic J (2004) Geology and tectonic evolution of Paleoproterozoic basins of the eastern Capricorn Orogen, Western Australia. Precambrian Res 128:315-342. 
Rey PF, Philippot P, Thébaud N (2003) Contribution of mantle plumes, crustal thickening and greenstone blanketing to the 2.75-2.65 Ga global crisis. Precambrian Res 127:43-60.

Rowe RJ, Awan AW, McCuaig TC, Sauter PC, Vickery NM (2002) Structural Geology of the Plutonic Gold Mine. Applied Structural Geology for Mineral Exploration and Mining International Symposium, Kalgoorlie, WA, pp. 180185.

Selway K, Sheppard S, Thorne AM, Johnson SP, Groeneweld PB (2009) Identifying the lithospheric structure of a Precambrian orogen using magnetotellurics: The Capricorn Orogen, Western Australia. Precambrian Res 168:185-196.

Stacey JS, Kramers JD (1975) Approximation of the terrestrial lead isotope evolution by a two-stage model. Earth Planet Sci Lett 26:207-221.

Steiger RH, Jäger E (1977) Subcommission on geochronology: convention on the use of decay constants in geo- and cosmochronology. Earth Planet Sci Lett 36:359-362.

Tyler IM, Hocking RM (2002) A revised geological framework for Western Australia. Western Australia Geological Survey, Annual Review 2000/1, 33-44.

Vickery NM (2004) The Plutonic Gold Deposit, Western Australia: Geology and Geochemistry of an Archaean Orogenic Gold System. PhD Dissertation, University of New England.

Vielreicher NM, McNaughton NJ (2002) SHRIMP U-Pb geochronology of magnetism and thermal events in the Archaean Marymia Inlier, central Western Australia. Int J of Earth Sci 91:406-432.

Vielreicher NM, Ridley JR, Groves DI (2002) Marymia: an Archean, amphibolite facies, hosted orogenic lode-gold deposit overprinted by Paleoproterozoic 
orogenesis and base metal mineralization, Western Australia. Mineral Deposita 37: 737-764.

Vielreicher NM, Groves DI, Snee LW, Fletcher IR, McNaughton NJ (2010) Broad Synchroneity of Three Gold Mineralization Styles in the Kalgoorlie Gold Field: SHRIMP, U-Pb and 40Ar/39Ar Geochronological Evidence. Econ Geol $105: 187-227$.

Vry JK, Baker JA (2006) LA-MC-ICPMS Pb-Pb dating of rutile from slowly cooled granulites: Confirmation of the high closure temperature of $\mathrm{Pb}$-diffusion in rutile. Geochim Cosmochim Acta 70:1807-1820.

White WM, Albarède F, Télouk P (2000) High-precision analysis of Pb isotope ratios by multi-collector ICP-MS. Chem Geol 167:257-270.

Willigers BJA, Baker JA, Krogstad EJ, Peate D (2002) Precise and accurate in situ $\mathrm{Pb}-\mathrm{Pb}$ dating of apatite, sphene and monazite by laser ablation multiplecollector ICP-MS. Geochim Cosmochim Acta 66:1051-1066.

Willigers BJA, Mezger K, Baker JA (2004) Development of high precision Rb-Sr phlogopite and biotite geochronology: an alternative to 40Ar/39Ar mica dating? Chem Geol 213:339-358. 


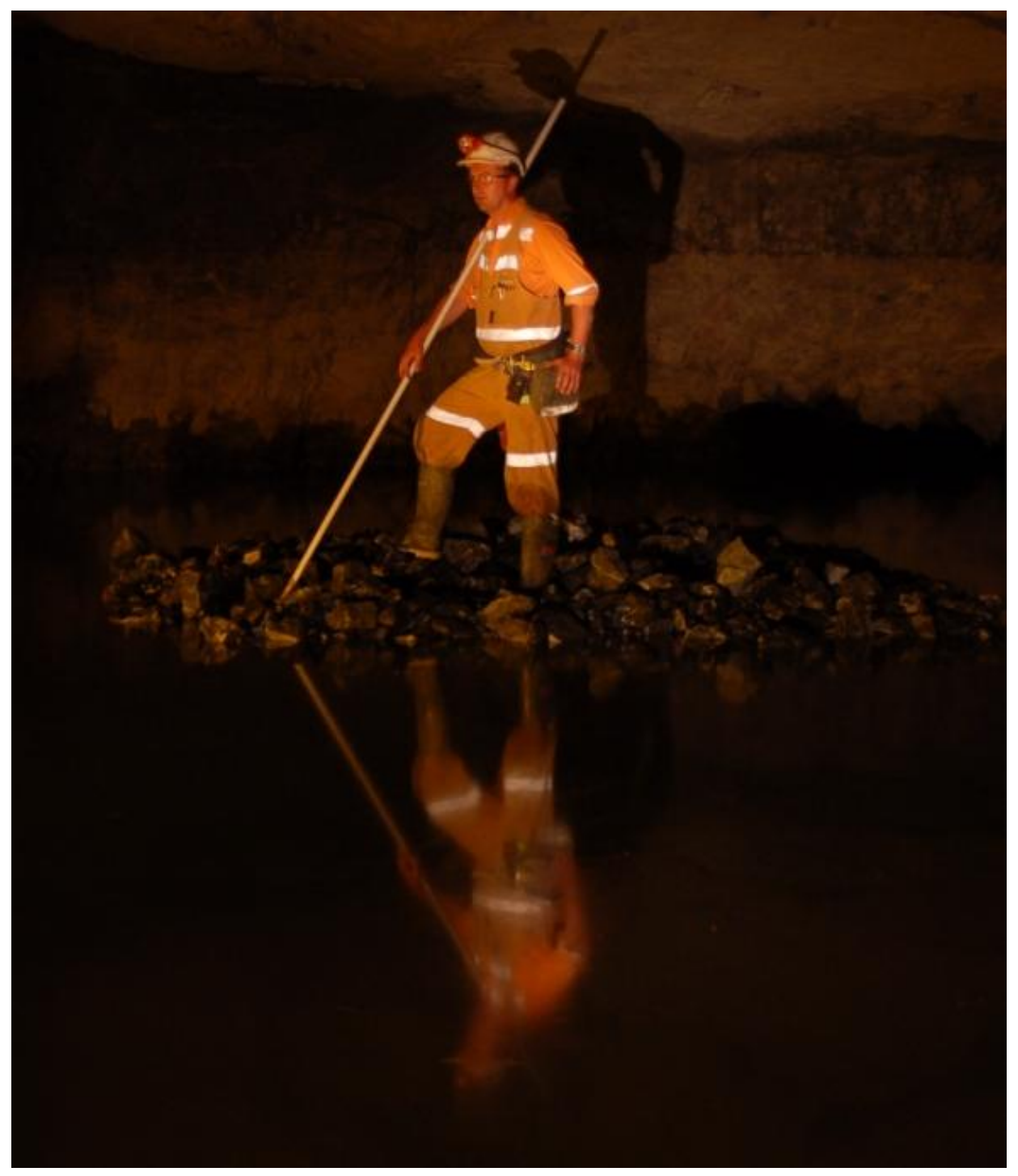

Travis in the looking glass. 


\section{CHAPTER 5 \\ KEY OUTCOMES, IMPLICATIONS AND FUTURE WORK}

Plutonic is a giant Archaean lode-Au deposit that is hosted in amphibolite-facies metamorphic rocks. As such, it differs markedly from more well-known giant deposits from greenschist-facies settings, such as Kalgoorlie (Eastern Goldfields, Western Australia) and Timmins (Canada), on which much of our understanding of Archaean lode-Au mineralisation has been based. The new results from Plutonic are important because they contribute to our understanding of Archaean lode-Au mineralisation in higher-grade metamorphic settings, and may help alleviate possible biases in understanding that have arisen from a focus on deposits in lower-grade metamorphic settings (cf. Barnicoat et al., 1991). In the preceding chapters, new data has been presented for Plutonic. The results obtained: (a) reveal for the first time a detailed stratigraphy for the metabasaltic rocks at Plutonic, and demonstrate the strong control that stratigraphy had on localising Au mineralisation; (b) reinterpret the $P-T$ path and peak pressure conditions for the amphibolite-facies metamorphism; and (c) add to our understanding of the timing of Au mineralisation and metasomatic episodes at Plutonic.

Chapter 2 showed that it is possible to readily identify individual lava flow units on the basis of $\mathrm{Cr}$, $\mathrm{Ti}$ and $\mathrm{Zr}$ concentrations in an otherwise largely featureless sequence of metabasalts using pXRF data. Gold mineralisation was focused along flow boundaries through the action of fluids as suggested by the strong correlation between $\mathrm{Au}$ and $\mathrm{K}$. Chrome, Ti and $\mathrm{Zr}$ data reveal fractionation trends in the Mine Mafic Package that are consistent with evolution in a magma chamber, with one probable major recharge event. The results support the previous interpretation that the 
metabasalt sequence is overturned, and provide evidence that the Mine Mafic Package is not the product of tectonic stacking of an originally thinner smaller unit as a result of deposit-scale folding or faulting, but rather variations in thickness are the result of primary stratigraphy. The new model for the dominant control on Au mineralisation differs significantly from the previous model in which Au mineralisation was associated with shearing and mylonitisation between thrust-duplexed slices of the Mine Mafic Package (cf. Rowe et al., 2002; Vickery, 2004), and potentially opens new areas of the Mine Mafic Package for Au exploration as there is less of a requirement for structurally complex areas.

After the publication of the paper presented in Chapter 2, further pXRF data was collected by the geology department at Plutonic, following the method developed in this study. The results showed that different mafic units could be followed along through the deposit for a distance $>2 \mathrm{~km}$ (Figure 5.1). This 2-D stratigraphy was further expanded in a recent publication by visualising the stratigraphy it in 3-D (Gazley et al., 2011c). The demonstration that pXRF results can be used together with Au-assay data to both reveal important details of an otherwise-obscure stratigraphy, and show that stratigraphy may have controlled Au mineralisation, has the potential for wide application. A paper on pXRF methods $r$ is currently being written in conjunction with researchers at CSIRO to enable other workers to collect pXRF data consistent with our understanding of best practices. This paper should be submitted for publication in late 2011 or early $2012 .^{10}$

\footnotetext{
${ }^{10}$ Fisher, L.A., Gazley, M.F., Barnes, S.J., Cleverley, J., Duclaux, G., in prep. Resolution of geochemical and lithostatigraphic complexity: application of portable X-ray fluorescence to mineral exploration. Journal of Geochemical Exploration.

This paper builds on Morris (2009) and Gazley et al. (2011a) to provide a more in-depth explanation of our current understanding of the best way to reliably analyse samples by pXRF. It will also provide new case studies which highlight the application of pXRF data in different fashions.
} 


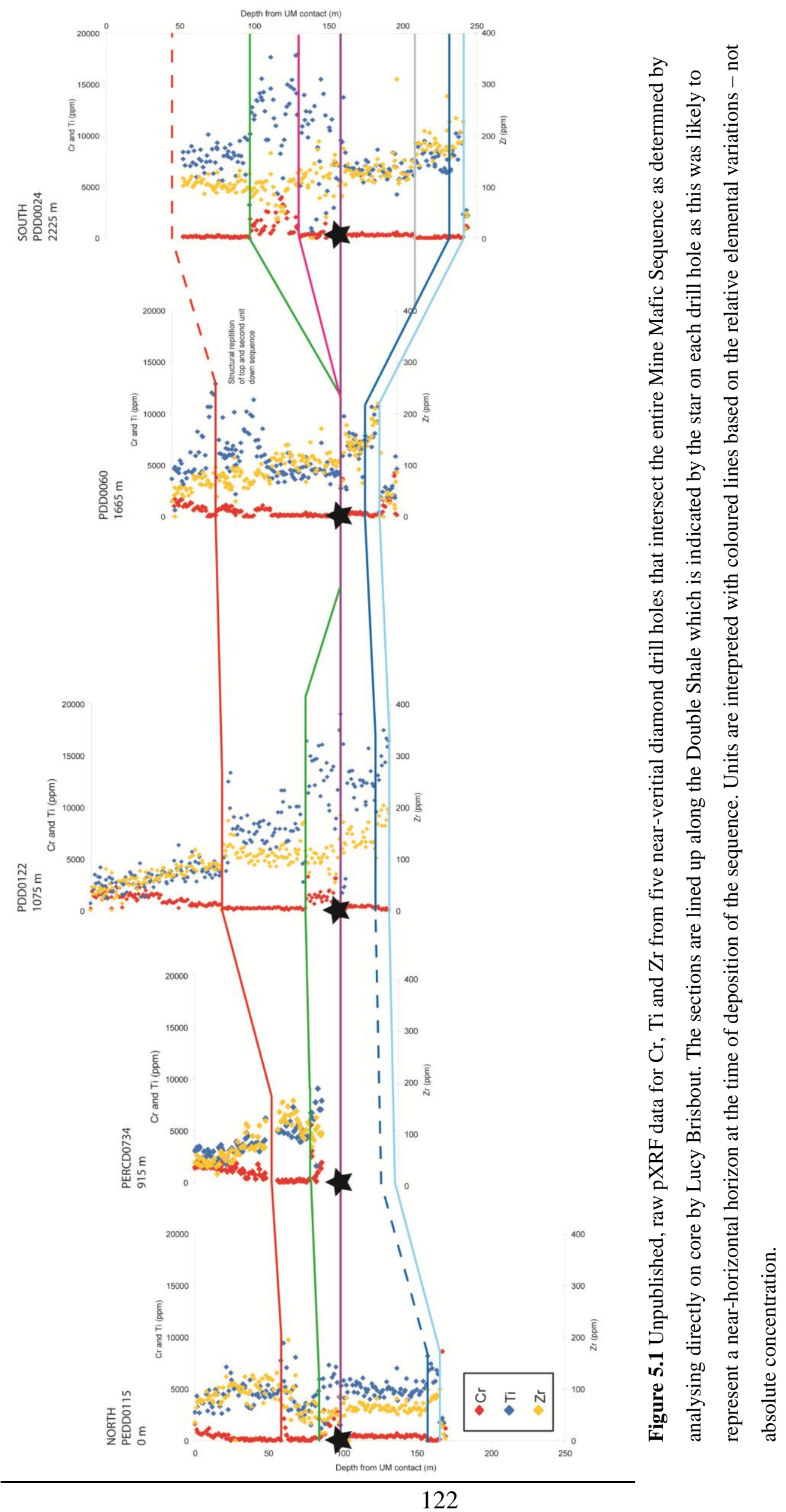


In Chapter 3, results of detailed petrologic studies of two metamorphosed mafic rock samples and $P-T$ pseudosection calculations that incorporate recent advances in modelling the activity-composition relationships of amphiboles and sulphide minerals (e.g. Diener et al., 2007; Bhadra \& Bhattacharya, 2007; Evans et al., 2010) were used to reinterpret the $P-T$ history of the PWGB. The results show that the metamorphosed mafic rocks at Plutonic record a previously-unrecognised steep increase in pressure from $\sim 3-4$ kbar at $\sim 500-550{ }^{\circ} \mathrm{C}$, to $\geq 8 \mathrm{kbar}$ at $\sim 600{ }^{\circ} \mathrm{C}$. The significant change in pressure associated with peak metamorphism has not previously been recognised, and is important, as it both implies that an episode of orogeny took place at that time, and requires amechanism by which a large body of rock could be taken to significant depth and later exhumed. Two models are suggested, one involving alpine-type horizontal tectonics, and the other involving vertical tectonics (e.g. Figure 5.2). At present, the lack of evidence for thickening by either thrust-stacking or folding, the cause of this steep increase in pressure remains unresolved.

The new $P-T$ determinations presented in Chapter $\mathbf{3}$ were derived only from hornblende-bearing metamorphosed mafic rocks and show that meaningful $P-T$ constraints can be derived directly from mafic rocks. This demonstrates that the advances in mineral modelling are sufficient to investigate changes in petrology in mafic rocks with the same kind of veracity as has been possible for pelitic rocks for some time (Diener et al., 2007). The approach used here is readily applicable at locations where metamorphosed mafic rocks that contain suitable mineral assemblages exist and are not unduly retrogressed. The ability to extract meaningful $P-T$ constraints directly from the abundant metamorphosed mafic rocks of Archaean greenstone belts, without relying on less-common intercalated rock types, should aid 
interpretation of the metamorphic and geodynamic history of mafic-hosted mineral deposits and greenstone belts worldwide.

(a)

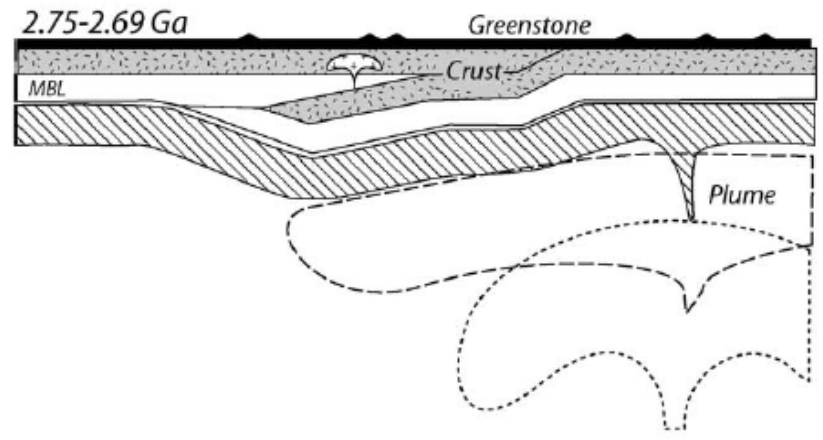

$2.69-2.65 \mathrm{Ga}$

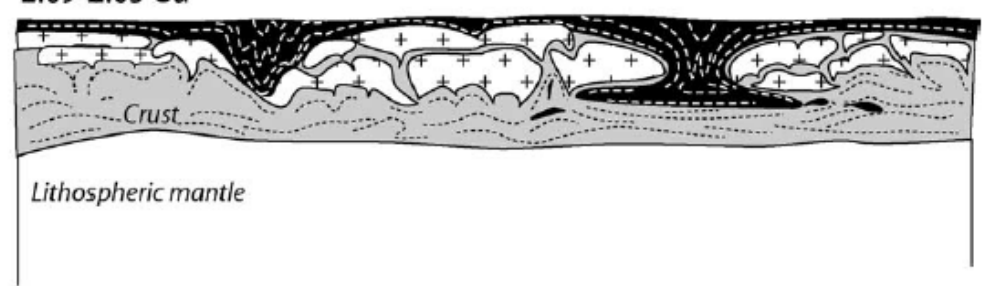

(b)

Fig. 9. Two-stage model to explain reworking of the crust during the Late Archaean. (a) Plume heads spread under Mechanical Boundary Layer (MBL), following major reorganisation of convection in the deep mantle. Locally, plumes interfere with plate-tectonic processes. Melt extracted from the plumes forms either thick greenstone covers that bury pre-existing continental crusts or plateaux in oceanic basins. (b) The insulation of heat-producing crust (felsic or mafic) combined with heat transfer from the plume lead to the partial melting of the crust $20-40 \mathrm{Myr}$ after the emplacement of the plume. Because of the density inversion represented by a greenstone cover over a felsic basement and following the thermal softening of the felsic basement, gravitational instabilities develop during which greenstone covers sink into the partially molten crust, thus providing space for granitoid domes. Again gravity-driven processes can interfere with plate-boundary processes (Choukroune et al., 1995, 1997). As radiogenic elements concentrate in granitoids, they accumulate in the upper part of the crust inducing cooling, strengthening and finally stabilisation of the craton.

Figure 5.2 Reproduction of Figure 9 from Rey et al. (2003) to explain the concept of gravity-driven, or vertical, tectonics.

The approach of overlaying THERMOCALC $P-T$ pseudosections for differentcomposition mafic rocks that have experienced the same metamorphic conditions gave tighter constraints on the prograde and peak metamorphic conditions than could be achieved using a single $P-T$ pseudosection. Metamorphic devolatilisation accompanying temperature increases, or possibly metamorphic fluid production during exhumation (e.g. Vry et al., 2010), may have led to the widely-recognised major episode of mineralisation that shortly followed the metamorphic peak and could 
explain some of the Au mineralisation events that continued periodically thereafter (e.g. McMillan, 1996; Vickery et al., 1998; Rowe et al., 2002; Vielreicher et al., 2002; Chapter 4). The amount of fluid that can be produced on a Plutonic-type amphibolite-facies $P-T$ path is the subject of ongoing research ${ }^{11}$.

The new geochronology data presented in Chapter 4, coupled with that previously available (McMillan, 1996; Vielreicher \& McNaughton, 2002; Vielreicher et al., 2002; Vickery 2004), record a geological history that has some events corresponding to those of other Au deposits within the PWGB, and the wider Yilgarn Craton. Four Au-mineralising events are identified at Plutonic which occurred at $\sim 2650 \mathrm{Ma}$, $\sim 2200 \mathrm{Ma}, \sim 1850 \mathrm{Ma}$, and 1730-1660 Ma. The geological history of the Plutonic area is summarised in Figure 5.3. Perhaps most significantly, the major Aumineralising event that is inferred to have occurred at $\sim 2200 \mathrm{Ma}$ is more than 400 Myr later than previously expected for Plutonic, the PWGB, or the Yilgarn Craton (e.g. Barnicoat et al., 1991; McMillan, 1996; Groves et al., 1995; Groves et al., 2000; Vielreicher et al., 2002; Robert et al., 2005; Vielreicher et al., 2010). There is little direct evidence as to what may have driven Au mineralisation at this time in the Plutonic area, but Au deposition at Plutonic was long-lived, with Au being concentrated in the same area for $\sim 1000 \mathrm{Myr}$ (between $\sim 2650 \mathrm{Ma}$ and $\sim 1660 \mathrm{Ma}$ ). The new ages for Au mineralisation have perhaps the most important implications that have arisen from this research in regards to future exploration for Au. Rocks that

\footnotetext{
${ }^{11}$ Gazley, M.F., Boorman, J.C., Duclaux, G., Vry, J.K.., in prep. Formation of multi-generation gold deposits by fluid production during metamorphic devolatilisation and exhumation. Journal of Metamorphic Geology.

This paper will present a model for the formation of multi-generation gold deposits by fluid production on the retrograde $P$ - $T$ path, building on the ideas of Vry et al. (2010). By assuming that the bulk composition of MORB represents that of a greenstone belt, this paper uses THERMOCALC modelling to assess the amount of fluid generated on the prograde and retrograde $P$ - $T$ paths, and thereby the opportunities for new fluid to be introduced into a mineral system that has the potential to transport, remobilise or concentrate gold.
} 
surround the Marymia Inlier (which are <2200 Ma), which were not previously considered particularly prospective for Au mineralisation, have potential to have been affected by the same Au-mineralising events as formed a giant deposit at Plutonic.

The rocks of the Plutonic area were affected by amphibolite-facies metamorphism to high pressures $\left(\geq 8 \mathrm{kbar}\right.$ at $\sim 600^{\circ} \mathrm{C}$ ) at $\sim 2660-2630 \mathrm{Ma}$. During the period that followed, there were a number of Au-mineralisation events that were undoubtedly associated with metasomatic activity. A metasomatic event at $\sim 1720 \mathrm{Ma}$ has been dated by both U-Pb dating of zircon overgrowths (McMillan, 1996; Vielreicher \& McNaughton, 2002), and $\mathrm{Pb}-\mathrm{Pb}$ dating of sphene (Chapter 4). This metasomatic event was probably also associated with $\mathrm{Au}$ mineralisation, as the $\mathrm{Pb}$-isotope ages for the final Au-mineralising event range from 1730-1660 Ma.

At the end of this study, it has become apparent that Plutonic fits even more poorly into the crustal continuum model (e.g. Groves et al., 1992; Groves, 1993), than it did at the start. Peak metamorphism occurred at 2660-2630 Ma, which is synchronous with that in the Yilgarn Craton (e.g. Barnicoat et al., 1991; Groves et al., 1995; Groves et al., 2000; Vielreicher et al., 2002; Robert et al., 2005; Vielreicher et al., 2010), but multiple Au-mineralisation events have occurred at the deposit, the youngest of which is approximately 1,000 Myr post-peak metamorphism. This long period of mineralisation does not appear to be consistent with any simple application of either the crustal continuum model of Groves et al. (1992) and Groves (1993), in which Au mineralisation closely associated with peak metamorphism, or the metamorphic devolatilisation model of Phillips \& Powell (2010), in which hydrated 


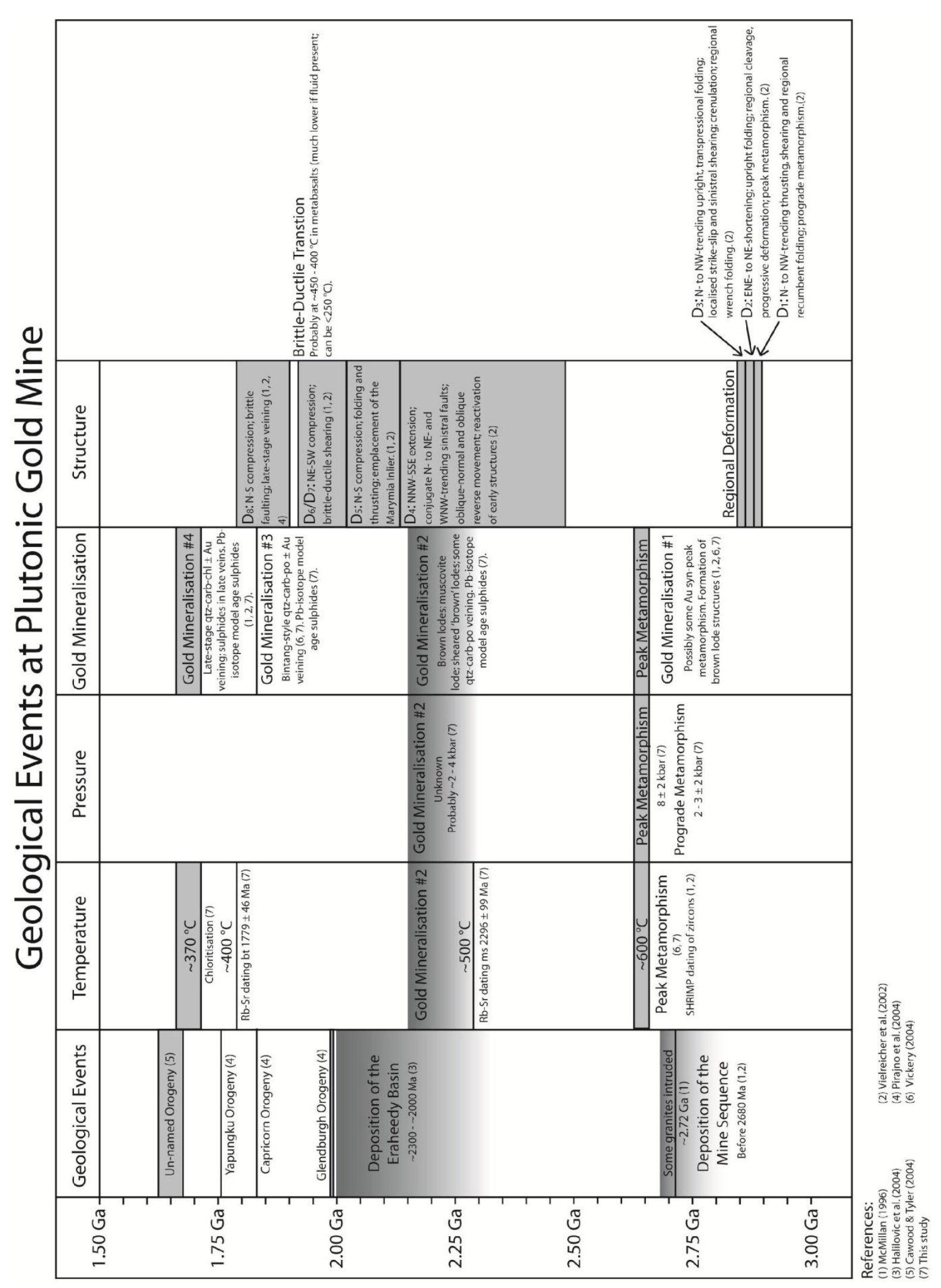

Figure 5.3 Summary diagram of geological events at Plutonic Gold Mine after this study. 
and carbonated greenschist facies rocks, particularly metabasic rocks, are devolatilised primarily across the greenschist-amphibolite facies transition in an orogenic setting. While the possibility exists that discrete episodes of metamorphic devolatilisation from the mafic rocks may have occurred during the uplift and exhumation (e.g. Vry et al., 2010), it seems improbable that any single event, or any model based on a single event, will explain all the features of Au mineralisation at Plutonic.

Plutonic is certainly an unusual deposit ${ }^{12}$. It is geographically isolated from the Yilgarn Craton, and the high (amphibolite-facies) metamorphic grade means that it is not an Au deposit in the typical Eastern Goldfields context (e.g. Witt, 1991). The results presented herein add to our understanding of deposits hosted in relatively highgrade metamorphic rocks. While there is some early Au at Plutonic that is associated with peak metamorphism at 2660-2630 Ma, the new Pb-isotope data indicate that significant Au mineralisation occurred in the Proterozoic. During the course of this study our understanding of Plutonic has been greatly improved; however, there much more to learn, and Plutonic will remain an unusual, and possibly unique, enigmatic Au deposit.

\footnotetext{
${ }^{12}$ A review paper that summarises our present understanding at the end of this study, and midway through ongoing research with CSIRO is in preparation:

Gazley, M.F., Vry, J.K, Duclaux, G., du Plessis, E., et al., in prep. An overview of an ArchaeanProterozoic gold mineralising system: Plutonic Gold Mine, Marymia Inlier, Western Australia. Economic Geology.
} 


\section{COMPLETE REFERENCE LIST}

Ashwal, L.D., Tucker, R.D., \& Zinner, E.K., 1999. Slow cooling of deep crustal granulites and Pb-loss in zircon. Geochimica et Cosmochimica Acta, 63, 2839-2851.

Ando, A., Kamioka, H., Terashima, S., \& Itoh, S., 1989. 1988 values for GSJ rock reference samples “Igneous Rock Series”. Geochemical Journal, 23, 143-148.

Awan, A., 2000. Geology and structural modelling of Plutonic Gold Mine with specific reference to the area covering underground mine development. Homestake Mining Company (Australia) Ltd., unpublished report, pp. 56.

Bagas, L., 1999. Early tectonic history of the Marymia Inlier and correlation with the Archaean Yilgarn Craton, Western Australia. Australian Journal of Earth Sciences, 46, 115-125.

Baker, J.A., Peate, D.W., Waight, T.E., \& Meyzen, C., 2004. High-precision Pb isotopic analysis of standards and samples using thallium and a lead double spike with a double focusing MC-ICPMS. Chemical Geology, 211, 275-303.

Barnicoat, A.C., Fare, R.J., Groves, D.I., \& McNaughton, N.J., 1991. Synmetamorphic lode-gold deposits in high-grade Archaean settings. Geology, 19, pp. $921-924$.

Bédard, L.P., \& Barnes, S.-J., 2010. How fit are your data? Geostandards and Geoanalytical Research, 34, 275-280. 
Bhadra, S. \& Bhattacharya, A., 2007. The barometer tremolite + tschermakite +2 albite $=2$ pargasite +8 quartz: Constraints from experimental data at unit silica activity, with application to garnet-free natural assemblages. American Mineralogist, 92, 491-502.

Carr, G.R., Dean, J.A., Suppel, D.W., \& Heithersay, P.S., 1995. Precise lead isotope fingerprinting of hydrothermal activity associated with Ordovician to Carboniferous metallogenic events in the Lachlan Fold Belt of New South Wales. Economic Geology, 90, 1467-1505.

Cawood, P.A., \& Tyler, I.M., 2004. Assembling and reactivating the Proterozoic Capricorn Orogen: lithotectonic elements, orogenies, and significance. Precambrian Research, 128, 201-218.

Cawthorn, R.G., \& McCarthy, T.S., 1980. Variations in Cr content of magnetite from the upper zone of the Bushveld Complex - Evidence for heterogeneity and convection currents in magma chambers. Earth and Planetary Science Letters, 46, 335-343.

Cawthorn, R.G., \& McCarthy, T.S., 1985. Incompatible trace element behaviour in the Bushveld Complex. Economic Geology, 80, 1016-1026.

Cawthorn, R.G., Maske, S., de Wet, M., Groves, D.I., \& Cassidy, K.F., 1988.

Contrasting magma types in the Mount Ayliff Intrusion (Insizwa Complex), Transkei: Evidence from ilmenite compositions. Canadian Mineralogist, 26, 145-160. 
Champion, D.C., \& Cassidy, K.F., 2007. An overview of the Yilgarn Craton and its crustal evolution, in Proceedings of Geoconferences (WA) Inc. Kalgoorlie '07 Conference, 25-27 September 2007, Kalgoorlie, Western Australia, Bierlein F.P. \& Knox-Robinson C.M., (eds), Geoscience Australia Record 2007/14, 8-13.

Chardon, D., Gapais, D. \& Cagnard., F., 2009. Flow in ultra-hot orogens: a view from the Precambrian, clues for the Phanerozoic. Tectonophysics, 477, 105-118.

Cherniak, D.J., 2010. Diffusion in carbonate, fluorite, sulfide minerals, and diamond. Reviews in Mineralogy \& Geochemistry, 72, 871-897.

Cherniak, D.J., \& Dimanov, A., 2010. Diffusion in pyroxene, mica, and amphibole. Reviews in Mineralogy \& Geochemistry, 72, 641-690.

Collins, W.J., Van Kranendonk, M.J., \& Teyssier, C., 1998. Partial convective overturn of Archaean crust in the east Pilbara Craton, Western Australia: driving mechanisms and tectonic implications. Journal of Structural Geology, 20, 1405-1424.

Cumming, G.L., \& Richards, J.R., 1975. Ore lead isotope ratios in a continuously changing earth. Earth and Planetary Science Letters, 28, 155-171.

Delevaux, M.H., Doe, B.R., \& Brown, G.F., 1967. Preliminary lead isotope investigations of brine from the Red Sea, galena from the Kingdom of Saudi Arabia 
and galena from United Arab Republic (Egypt). Earth and Planetary Science Letters, 3, 139-144.

Diener, J.F.A., Stevens, G., Kisters, A.F.M. \& Poujol, M., 2005. Metamorphism and exhumation of the basal parts of the Barberton greenstone belt, South Africa: Constraining the rates of Mesoarchaean tectonism. Precambrian Research, 143, 87 112.

Diener, J.F.A., Powell, R., White, R.W. \& Holland, T.J.B., 2007. A new thermodynamic model for clino- and orthoamphiboles in the system $\mathrm{Na}_{2} \mathrm{O}-\mathrm{CaO}-\mathrm{FeO}-$ MgO- $\mathrm{Al}_{2} \mathrm{O}_{3}-\mathrm{SiO}_{2}-\mathrm{H}_{2} \mathrm{O}-\mathrm{O}$. Journal of Metamorphic Geology, 25, 631-656.

Dipple, G.M., \& Ferry, J.M., 1992. Metasomatism and fluid flow in ductile fault zones. Contributions to Mineralogy and Petrology, 112, 149-164.

Evans, K.A., 2006. Redox decoupling and redox budgets: Conceptual tools for the study of earth systems. Geology, 34, 489-492.

Evans, K.A., Powell, R. \& Holland, T.J.B., 2010. Internally consistent data for sulphur-bearing phases and application to the construction of pseudosections for mafic greenschist facies rocks in $\mathrm{Na}_{2} \mathrm{O}-\mathrm{CaO}-\mathrm{K}_{2} \mathrm{O}-\mathrm{FeO}-\mathrm{MgO}-\mathrm{Al}_{2} \mathrm{O}_{3}-\mathrm{SiO}_{2}-\mathrm{CO}_{2}-\mathrm{O}-\mathrm{S}-$ $\mathrm{H}_{2} \mathrm{O}$. Journal of Metamorphic Geology, 28, 667-687.

Fallon, M., Porwal, A., \& Guj, P., 2010. Prospectivity analysis of the Plutonic Marymia Greenstone Belt, Western Australia. Ore Geology Reviews, 38, 208-218. 
Force, E.R., 1991. Geology of titanium-mineral deposits. Geological Society of America, Special Paper No. 259, pp. 112.

Gain, S.B., 1985. The geologic setting of the Platiniferous UG-1 Chromite Layer on the Farm Maandagoshoek, Eastern Bushveld Complex. Economic Geology, 80, $925-$ 943.

Gazley, M.F., Vry, J.K., du Plessis, E., \& Handler, M.R., 2011a. Application of handheld X-ray fluorescence analyses to Metabasalt Stratigraphy, Plutonic Gold Mine, Western Australia. Journal of Geochemical Exploration, 110, 74-80.

Gazley, M.F., Vry, J.K., \& Boorman, J.C., 2011b. $P-T$ evolution in greenstone belt mafic amphibolites: an example from Plutonic Gold Mine, Marymia Inlier, Western Australia. Journal of Metamorphic Geology, 29, 685-697.

Gazley, M.F., Duclaux, G., Fisher, L.A., de Beer, S., Smith, P., Taylor, M., Swanson, R.M., Hough, R., Cleverley, J., 2011b. Improving geological and metallurgical understanding of Plutonic Gold Mine, Western Australia, using 3-D visualisation of portable X- Ray fluorescence data. AusIMM 2011, Eighth International Mining Geology Conference, Queenstown, New Zealand, August 2011, 385-394.

Gazley, M.F., Vry, J.K., Millet, M.-A., Handler, M.R., du Plessis, E., Baker, J.A., in submission. New timing constraints on Archean-Proterozoic gold mineralization, 
metamorphism, and metasomatism at Plutonic Gold Mine, Marymia Inlier, Western Australia. Mineralium Deposita.

Goldfarb, R.J., Groves, D.I. \& Gardoll, S., 2001. Orogenic gold and geological time: a global synthesis. Ore Geology Reviews, 18, 1-75

Green, E.C.R., Holland, T.J.B., \& Powell, R., 2007. An order-disorder model for omphacitic pyroxenes in the system jadeite-diopside-hedenbergite-acmite, with applications to eclogite rocks. American Mineralogist, 92, 1181-1189.

Groves, D.I., Barley, M.E., Barnicoat, A.C., Cassidy, K.F., Fare, R.J., Hagemann, S.G., Ho, S.E., Hronsky, J.M.A., Mickuki, E.J., Mueller, A.G., McNaughton, N.J., Perring, C.S., Ridley, J.R., \& Vearncombe, J.R., 1991. Sub-greenschist to granulitehosted Archaean lode-gold deposits of the Yilgarn Craton: a depositional continuum from deep-sourced fluids in crustal-scale plumbing systems. Geology Department (Key Centre) and University Extension, The University of Western Australia Publication, 22, pp. 325-337.

Groves, D.I., 1993. The crustal continuum model for late-Archaean lode-gold deposits of the Yilgarn Block, Western Australia. Mineralium Deposita, 28, 366-374.

Groves, D.I., Ridley, J.R., Bloem, E.M.J, Gebre-Mariam, M., Hagemann, S.G., Hronsky, J.M.A, Knight, J.T., NcNaughton, N.J., Ojala, J., Vielreicher, R.M., McCuaig, T.C., \& Holyland, P.W., 1995. Lode-gold deposits of the Yilgarn block: products of Late Archaean crustal-scale overpressured hydrothermal systems. In Early 
Precambrian Processes, Coward, M.P., \& Ries, A.C., (eds), Geological Society of London Special Publication, 95, pp. 155-172.

Groves, D.I., Goldfarb, R.J., Gebre-Mariam, M., Hagemann, S.G., \& Robert, F., 1998. Orogenic gold deposits: A proposed classification in the context of their crustal distribution and relationship to other gold deposit types. Ore Geology Reviews, 13, pp. $7-27$.

Groves, D.I., Goldfarb, R.J., Knox-Robinson, C.M., Ojala, J., Gardoll, S., Yun, G.Y., \& Holyland, P., 2000. Late-kinematic timing of orogenic gold deposits and significance for computer based exploration techniques with emphasis on the Yilgarn Block, Western Australia. Ore Geology Reviews, 17, 1-38

Groves, D.I., Goldfarb, R.J., Robert, F., \& Hart, C.J.R., 2003. Gold Deposits in Metamorphic Belts: Overview of Current Understanding, Outstanding Problems, Future Research, and Exploration Significance. Economic Geology, 98, 1-29.

Guj, P., Fallon, M., McCuaig, T.C., \& Fagan, R., 2011. A Time-Series Audit of Zipf’s Law as a Measure of Terrane Endowment and Maturity in Mineral Exploration. Economic Geology, 106, 241-259.

Hagemann, S.G., Groves, D.I., Ridley, J.R., \& Vearncombe, J.R., 1992. The Archean lode-gold deposits at Wiluna, Western Australia: high-level brittle-style mineralization in a strike-slip regime. Economic Geology, 87, 1022-1053. 
Hagemann, S.G., Brown, P.E., Ridley, J., Stern, P., \& Fournelle, J., 1998. Ore petrology, chemistry and timing of electrum in the Archean hypozonal Transvaal lode gold deposit, Western Australia. Economic Geology, 93, 271-291.

Heinrichs, H. \& Herrmann, A. G., 1990. Praktikum der Analytischen Geochemie, Springer-Verlag, Berlin-Heidelberg-New York, pp. 669.

Hiemstra, S.A., 1985. The Distribution of Some Platinum-Group Elements in the UG2 Chromite Layer of the Bushveld Complex. Economic Geology, 80, 944-957.

Ho, S.E., McNaughton, N.J., \& Groves, D.I., 1994. Criteria for determining initial Pbisotope compositions of pyrite in Archaean lode-gold deposits: a case study at Victory, Kambalda, Western Australia. Chemical Geology, 111, 57-84.

Holland, T. \& Blundy, J., 1994. Non-ideal interactions in calcic amphiboles and their bearing on amphibole-plagioclase thermometry. Contributions to Mineralogy and Petrology, 116, 433-447.

Holland, T. J. B., Baker, J. \& Powell, R., 1998. Mixing properties and activitycomposition relationships of chlorites in the system $\mathrm{MgO}-\mathrm{FeO}-\mathrm{Al}_{2} \mathrm{O}_{3}-\mathrm{SiO}_{2}-\mathrm{H}_{2} \mathrm{O}$. European Journal of Mineralogy, 10, 395-406

Holland, T. J. B. \& Powell, R., 1998. An internally consistent thermodynamic data set for phases of petrological interest. Journal of Metamorphic Geology, 16, 309-343. 
Holland, T.J.B., \& Powell, R., 2003. Activity-composition relations for phases in petrological calculations: an asymmetric multicomponent formulation. Contributions to Mineralogy and Petrology, 145, 492-501.

Kretz, R., 1983. Symbols for rock-forming minerals. American Mineralogist, 68, $277-279$.

MacDougall, D., \& Crummett, W.B., 1980. Guidelines for data acquisition and data quality evaluation in environmental chemistry. Analytical Chemistry, 52, 2242-2249.

Martin, D.McB., \& Morris, P.A., 2010. Tectonic setting and regional implications of ca. 2.2 Ga mafic magmatism in the southern Hamersley Province, Western Australia. Australian Journal of Earth Science, 57, 911-931.

McMillan, N.M., 1996. Late-Archaean, syn-amphibolite facies, lode-gold deposits overprinted by Palaeoproterozoic deformation, metasomatism and hydrothermal activity at Marymia, Western Australia. Unpublished PhD thesis, University of Western Australia, pp. 453.

McNaughton, N.J., 1987. Lead-Isotope Systematics for Archaean Sulfide Studies. in Ho, S.E., \& Groves, D.I., (eds), Recent Advances in Understanding Precambrian Gold Deposits. Geology Department and University Extension, University of Western Australia, Publication 11. 
McNaughton, N.J., \& Groves, D.I., 1996. A review of Pb-isotope constraints of the genesis of lode-gold deposits in the Yilgarn Craton, Western Australia. Journal of the Royal Society of Western Australia, 28, 123-129.

McNaughton, N.J., \& Dahl, N., 1987. A geochronological framework for gold mineralization in the Yilgarn Block, Western Australia. in Ho, S.E., \& Groves, D.I., (eds), Recent Advances in Understanding Precambrian Gold Deposits. Geology Department and University Extension, University of Western Australia, Publication 11.

Mikucki, E.J., \& Ridley, J.R., 1993. The hydrothermal fluid of Archaean lode-gold deposits at different metamorphic grades: compositional constraints from ore and wallrock alteration assemblages. Mineralium Deposita, 28, 469-481.

Morgan, R., 2004. The Lithogeochemical Characteristics of the Mine Mafic Within Zone 19 (The Baltic), Plutonic Gold Mine, Western Australia. Unpublished Honours Thesis, Curtin University of Technology, pp. 203.

Morris, P.A., 2009. Field-portable X-ray fluorescence analysis and its application in GSWA: Geological Survey of Western Australia, Record 2009/7, pp. 23.

Pirajno, F., Jones, J.A., Hocking, R.M. \& Halilovic, J., 2004. Geology and tectonic evolution of Palaeoproterozoic basins of the eastern Capricorn Orogen, Western Australia. Precambrian Research, 128, 315-342. 
Phillips, G.N., 1986. Geology and alteration of Golden Mile, Kalgoorlie. Economic Geology, 81, 779-808.

Phillips, G.N., \& Gibb, H.F.C., 1993. A century of mining at Kalgoorlie: Economic Geology Research Unit, Key Centre in Economic Geology, James Cook University of North Queensland, Contribution 45.

Phillips, G.N., Groves, D.I., \& Kerrich, R., 1996. Factors in the formation of the giant Kalgoorlie gold deposit. Ore Geology Reviews, 10, 295-317.

Powell, R., \& Holland, T.J.B., 1988. An internally consistent thermodynamic dataset with uncertainties and correlations: 3 : application methods, worked examples and a computer program. Journal of Metamorphic Geology, 6, 173-204.

Powell, R. \& Holland, T. J. B., 2008. On thermobarometry. Journal of Metamorphic Geology, 26, 155-179.

Rey, P.F., Philippot, P. \& Thébaud, N., 2003. Contribution of mantle plumes, crustal thickening and greenstone blanketing to the 2.75-2.65 Ga global crisis. Precambrian Research, 127, 43-60.

Rey, P.F. \& Houseman, G., 2006. Lithospheric scale gravitational flow: the impact of body forces on orogenic processes from Archaean to Phanerozoic in Buiter, S.J.H., Schreurs, G., (eds), 2006, Analogue and Numerical Modelling of Crustal-Scale Processes. Geological Society, London, Special Publications, 253, 153-167. 
Robert, F., Poulsen, K.H., Cassidy, K.F., \& Hodgson, C.J., 2005. Gold metallogney of the Superior and Yilgarn craton. Economic Geology $100^{\text {th }}$ Anniversary Volume, 10011033.

Robin, C.M.I, \& Bailey, R.C., 2009. Simultaneous generation of Archean crust and subcratonic roots by vertical tectonics. Geology, 37, 523-526.

Rowe, R.J., Awan, A.W., McCuaig, T.C., Sauter, P.C. \& Vickery, N.M., 2002. Structural Geology of the Plutonic Gold Mine. Applied Structural Geology for Mineral Exploration and Mining International Symposium, Kalgoorlie, WA, 180-185.

Spear, F.S. \& Kohn, M.J., 2001. Program: GTB, GeoThermobarometry: Rensselaer Polytechnic Instute. Available at http://ees.geo.rpi.edu/MetaPetaRen/GTB_Prog/GTB.html (last accessed on 10 February 2010).

Steiger, R.H., \& Jäger, E., 1977. Subcommission on geochronology: convention on the use of decay constants in geo- and cosmochronology. Earth and Planetary Science Letters, 36, 359-362.

Sun, S.-s. \& McDonough, W.F., 1989. Chemical and isotopic systematic of oceanic basalts: implications for mantle composition and processes in Saunders, A.D., Norry, M.J., (eds), 1989, Magmatism in the Ocean Basins, Geological Society Special Publication No. 42, 313-345. 
Swager, C. \& Griffin, T.J., 1990. An early thrust duplex in the Kalgoorlie-Kambalda greenstone belt, Eastern Goldfields Province, Western Australia. Precambrian Research, 48, 63-73.

Thébaud, N., Duclaux, G., Gessner, K. \& Doublier, M., 3D Thermal-mechanical models of Archean dome and keel formation: insights from Southern Cross District in Tyler, I.M., Knox-Robinson, C.M., 2010, Fifth International Archaean Symposium Abstracts: Geological Survey of Western Australia, Record 2010/18, pp. 410.

Tindle, A. \& Webb, P.C., 1994. Probe-AMPH - A spreadsheet program to classify microprobe-derived amphibole analyses. Computers and Geosciences, 20, 12011228.

Tyler, I.M. \& Hocking, R.M., 2002. A revision of the Tectonic Units of Western Australia. Western Australia Geological Survey, Annual Review 2000/1, 33-44.

Vickery, N.M., Buckley, P.M. \& Kellett, P.J., 1998. Plutonic gold deposit. Geology of Australian and Papua New Guinean Mineral Deposits; Berkman, D.A., McKenzie, D. (eds), The Australian Institute of Mining and Metallurgy: Melbourne, 71-80.

Vickery, N.M., 2004. The Plutonic Gold Deposit, Western Australia: Geology and Geochemistry of an Archaean Orogenic Gold System. Unpublished PhD thesis, University of New England, Australia, pp. 593. 
Vielreicher, N.M., Ridley, J.R. \& Groves, D.I., 2002. Marymia: an Archaean, amphibolite facies, hosted orogenic lode-gold deposit overprinted by Palaeoproterozoic orogenesis and base metal mineralisation, Western Australia. Mineralium Deposita, 37, 737-764.

Vielreicher, N.M. \& McNaughton, N.J., 2002. SHRIMP U-Pb geochronology of magnetism and thermal events in the Archaean Marymia Inlier, central Western Australia. International Journal of Earth Science, 91, 406-432.

Vielreicher, N.M., Groves, D.I., Snee, L.W., Fletcher, I.R., \& McNaughton, N.J., 2010. Broad Synchroneity of Three Gold Mineralization Styles in the Kalgoorlie Gold Field: SHRIMP, U-Pb and 40Ar/39Ar Geochronological Evidence. Economic Geology, 105, 187-227.

Vry, J.K., \& Baker, J.A., 2006. LA-MC-ICPMS Pb-Pb dating of rutile from slowly cooled granulites: Confirmation of the high closure temperature of $\mathrm{Pb}$-diffusion in rutile. Geochimica et Cosmochimica Acta, 70, 1807-1820.

Vry, J.K., Powell, R., Golden, K.M. \& Petersen, K., 2010. The role of exhumation in metamorphic dehydration and fluid production. Nature Geoscience, 3, 31-35.

White, R.W., Powell, R., Holland, T.J.B., \& Worley, B.A., 2000. The effect of $\mathrm{TiO}_{2}$ and $\mathrm{Fe}_{2} \mathrm{O}_{3}$ on metapelitic assemblages at greenschist and amphibolite facies conditions: mineral equilibria calculations in the system $\mathrm{K}_{2} \mathrm{O}-\mathrm{FeO}-\mathrm{MgO}-\mathrm{Al}_{2} \mathrm{O}_{3}-\mathrm{SiO}_{2}-$ $\mathrm{H}_{2} \mathrm{O}-\mathrm{TiO}_{2}-\mathrm{Fe}_{2} \mathrm{O}_{3}$. Journal of Metamorphic Geology, 18, 497-522. 
White, R.W., Powell, R. \& Holland, T.J.B., 2007. Progress relating to calculation of partial melting equilibria for metapelites. Journal of Metamorphic Geology, 25, 511527.

White, W.M., Albarède, F., \& Télouk, P., 2000. High-precision analysis of Pb isotope ratios by multi-collector ICP-MS. Chemical Geology, 167, 257-270.

Willigers, B.J.A., Baker, J.A., Krogstad, E.J., \& Peate, D., 2002. Precise and accurate in situ $\mathrm{Pb}-\mathrm{Pb}$ dating of apatite, sphene and monazite by laser ablation multiplecollector ICP-MS. Geochimica et Cosmochimica Acta, 66, 1051-1066.

Willigers, B.J.A., Mezger, K., \& Baker, J.A., 2004. Development of high precision $\mathrm{Rb}-\mathrm{Sr}$ phlogopite and biotite geochronology: an alternative to 40Ar/39Ar mica dating? Chemical Geology, 213, 339-358.

Witt, W.K., 1991. Regional metamorphic controls on alteration associated with gold mineralization in the Eastern Goldfields Province Western Australia: implications for the timing and origin of Archaean lode-gold deposits. Geology, 19, pp. 982-985. 


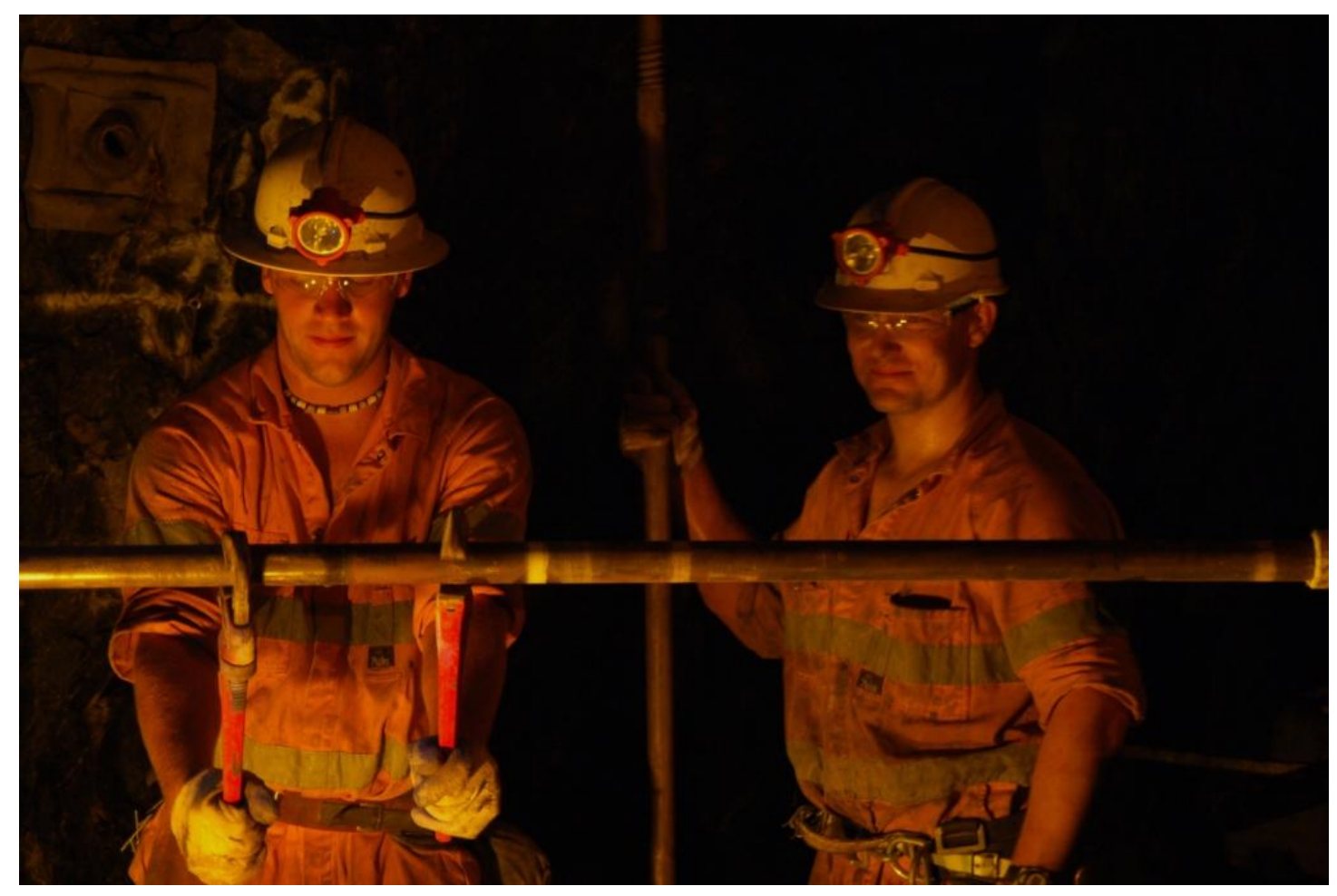

Diamond drillers cracking a drill string. 


\section{APPENDIX 1: Complete pXRF data for Chapter 2}

Table containing drill hole number, Plutonic sample number, depth down section from the contact between the upper Mine Mafic and Ultra Mafic, Au concentration by fire assay, and $\mathrm{K}, \mathrm{Ti}, \mathrm{Cr}$ and $\mathrm{Zr}$ concentrations as determined by $\mathrm{pXRF}$ analysis. $n$.a. $=$ not analysed; n.d. $=$ not detected. $*$ A gap exists in the data between $116-$ $120 \mathrm{~m}$ as one drill hole was drilled upwards and one down from a drill drive.

\begin{tabular}{|c|c|c|c|c|c|c|c|}
\hline Drill Hole & Sample & Depth (m) & Au (ppm) & $\mathbf{K}(\mathbf{p p m})$ & $\mathbf{T i}(\mathbf{p p m})$ & $\mathrm{Cr}(\mathbf{p p m})$ & $\mathrm{Zr}(\mathbf{p p m})$ \\
\hline UDD8337 & UD612331 & 0 & 0.09 & 1363 & 2092 & 838 & 45 \\
\hline UDD8337 & UD612330 & 0.6 & 4.19 & 1211 & 3143 & 1018 & 42 \\
\hline UDD8337 & UD612329 & 1.6 & 0.84 & 1973 & 2604 & 889 & 46 \\
\hline UDD8337 & UD612328 & 2.6 & 0.51 & 2092 & 3142 & 905 & 42 \\
\hline UDD8337 & UD612327 & 3.6 & 0.35 & 911 & 2242 & 834 & 46 \\
\hline UDD8337 & UD612326 & 4.6 & 0.45 & 1858 & 2109 & 742 & 41 \\
\hline UDD8337 & UD612325 & 5 & 0.92 & 2028 & 2628 & 894 & 42 \\
\hline UDD8337 & UD612324 & 5.5 & 0.56 & 1963 & 3431 & 948 & 38 \\
\hline UDD8337 & UD612323 & 6.1 & 0.48 & 7933 & 10872 & 94 & n.d. \\
\hline UDD8337 & UD612321 & 7.1 & 0.61 & 2156 & 3105 & 954 & 40 \\
\hline UDD8337 & UD612320 & 7.5 & 1.76 & 2471 & 4553 & 921 & 41 \\
\hline UDD8337 & UD612319 & 8.5 & 6.85 & 2302 & 1468 & 960 & n.d. \\
\hline UDD8337 & UD612318 & 9.5 & 7.33 & 2067 & 2163 & 1986 & n.d. \\
\hline UDD8337 & UD612316 & 10 & 3.66 & 7714 & 7365 & 68 & 168 \\
\hline UDD8337 & UD612314 & 10.6 & 10.4 & 3165 & 2463 & 2113 & n.d. \\
\hline UDD8337 & UD612313 & 11 & 11.9 & 6349 & 3380 & 2315 & 42 \\
\hline UDD8337 & UD612312 & 11.7 & 3.83 & 2388 & 3117 & 974 & 52 \\
\hline UDD8337 & UD612311 & 12.2 & 0.13 & 1710 & 3724 & 922 & 65 \\
\hline UDD8337 & UD612310 & 13.2 & 0.04 & 1880 & 2494 & 827 & 56 \\
\hline UDD8337 & UD612309 & 14.2 & 0.07 & 1558 & 3389 & 850 & 66 \\
\hline UDD8337 & UD612308 & 15.2 & 0.58 & 1767 & 3343 & 789 & 41 \\
\hline UDD8337 & UD612307 & 16.2 & 0.07 & 1116 & 3752 & 951 & 57 \\
\hline UDD8337 & UD612306 & 16.7 & 0.18 & 1401 & 3743 & 870 & 72 \\
\hline UDD8337 & UD612305 & 17.7 & 0.16 & 1502 & 2570 & 1301 & 53 \\
\hline UDD8337 & UD612304 & 18 & 0.03 & 1607 & 3608 & 733 & 50 \\
\hline UDD8337 & UD612303 & 19 & 0.04 & 1675 & 3359 & 1210 & 61 \\
\hline UDD8337 & UD612302 & 20 & 0.02 & 1596 & 2577 & 1197 & 64 \\
\hline UDD8337 & UD612301 & 21 & 0.29 & 1818 & 3314 & 1120 & 49 \\
\hline UDD8337 & UD612300 & 22 & 0.07 & 2391 & 1993 & 1202 & 46 \\
\hline UDD8337 & UD612298 & 22.8 & 0.14 & 5588 & 3673 & 1345 & 65 \\
\hline UDD8337 & UD612297 & 23.4 & 0.09 & 2381 & 4603 & 1379 & 55 \\
\hline UDD8337 & UD612296 & 24.4 & 0.02 & 1993 & 3868 & 1890 & 50 \\
\hline UDD8337 & UD612295 & 25.2 & 0.04 & 1652 & 4309 & 1289 & 50 \\
\hline UDD8337 & UD612294 & 26.2 & 0.05 & 1317 & 4038 & 1220 & 61 \\
\hline UDD8337 & UD612293 & 27.2 & 0.02 & 1235 & 3240 & 1052 & 56 \\
\hline UDD8337 & UD612292 & 28.2 & 0.02 & 1180 & 2023 & 1254 & 65 \\
\hline UDD8337 & UD612291 & 29.2 & 0.06 & 1497 & 2486 & 885 & 54 \\
\hline UDD8337 & UD612290 & 30.2 & 0.03 & 1735 & 2189 & 833 & 37 \\
\hline UDD8337 & UD612289 & 31 & 0.43 & 2517 & 2763 & 1014 & 71 \\
\hline UDD8337 & UD612288 & 32 & 0.2 & 1284 & 2755 & 841 & 64 \\
\hline UDD8337 & UD612287 & 33 & 0.02 & 1439 & 2616 & 1213 & 59 \\
\hline UDD8337 & UD612286 & 34 & 0.02 & 1121 & 1779 & 869 & 59 \\
\hline UDD8337 & UD612285 & 35 & 0.01 & 857 & 1610 & 860 & 57 \\
\hline UDD8337 & UD612284 & 36 & 0.01 & 990 & 2126 & 818 & 59 \\
\hline UDD8337 & UD612283 & 37 & 0.04 & 919 & 2765 & 1084 & 56 \\
\hline UDD8337 & UD612282 & 38 & 0.03 & 1498 & 2913 & 979 & 38 \\
\hline
\end{tabular}




\begin{tabular}{|c|c|c|c|c|c|c|c|}
\hline Drill Hole & Sample & Depth (m) & Au (ppm) & $\mathbf{K}(\mathbf{p p m})$ & Ti (ppm) & $\mathrm{Cr}(\mathbf{p p m})$ & $\mathrm{Zr}(\mathbf{p p m})$ \\
\hline UDD8337 & UD612281 & 39 & 0.02 & 1244 & 2527 & 1071 & 55 \\
\hline UDD8337 & UD612280 & 40 & 0.01 & 1323 & 2122 & 1074 & 60 \\
\hline UDD8337 & UD612279 & 41 & 0.02 & 8868 & 4589 & 83 & n.d. \\
\hline UDD8337 & UD612277 & 41.7 & 0 & 1325 & 2196 & 900 & 54 \\
\hline UDD8337 & UD612276 & 42.7 & 0.01 & 840 & 2543 & 1023 & 46 \\
\hline UDD8337 & UD612275 & 43.7 & 0.15 & 1358 & 1905 & 935 & 45 \\
\hline UDD8337 & UD612274 & 44.5 & 3.87 & 1909 & 2725 & 506 & 65 \\
\hline UDD8337 & UD612273 & 45 & 0.06 & 2405 & 3690 & 523 & 66 \\
\hline UDD8337 & UD612272 & 45.8 & 0.08 & 1430 & 2353 & 442 & 72 \\
\hline UDD8337 & UD612271 & 46.8 & 0.02 & 1337 & 2611 & 540 & 56 \\
\hline UDD8337 & UD612270 & 47.8 & 0 & 1692 & 2547 & 496 & 68 \\
\hline UDD8337 & UD612269 & 48.8 & 0.02 & 2236 & 2882 & 590 & 75 \\
\hline UDD8337 & UD612268 & 49.8 & 0.36 & 2254 & 3257 & 533 & 70 \\
\hline UDD8337 & UD612267 & 50.8 & 0.04 & 2110 & 3219 & 621 & 70 \\
\hline UDD8337 & UD612266 & 51.8 & 0.01 & 1258 & 3852 & 528 & 65 \\
\hline UDD8337 & UD612265 & 52.8 & 0.02 & 1926 & 3288 & 633 & 66 \\
\hline UDD8337 & UD612264 & 53.8 & 0 & 1944 & 3837 & 581 & 71 \\
\hline UDD8337 & UD612263 & 54.8 & 0 & 2685 & 3683 & 558 & 74 \\
\hline UDD8337 & UD612262 & 55.7 & 0.01 & 2184 & 3539 & 672 & 68 \\
\hline UDD8337 & UD612261 & 56.7 & 0.02 & 2932 & 3413 & 682 & 70 \\
\hline UDD8337 & UD612260 & 57.2 & 0 & 1333 & 3491 & 519 & 67 \\
\hline UDD8337 & UD612259 & 58.2 & 0.01 & 948 & 2636 & 628 & 72 \\
\hline UDD8337 & UD612258 & 59.2 & 0.04 & 1810 & 2918 & 534 & 45 \\
\hline UDD8337 & UD612256 & 60.2 & 0.02 & 986 & 3970 & 676 & 61 \\
\hline UDD8337 & UD612255 & 61.2 & 0.02 & 1304 & 3946 & 534 & 65 \\
\hline UDD8337 & UD612254 & 62.2 & 0 & 1540 & 4467 & 680 & 71 \\
\hline UDD8337 & UD612253 & 63.2 & 0 & 1055 & 3360 & 630 & 68 \\
\hline UDD8337 & UD612252 & 64.2 & 0.01 & 1250 & 3841 & 730 & 73 \\
\hline UDD8337 & UD612251 & 65.2 & 0 & 1106 & 3373 & 642 & 64 \\
\hline UDD8337 & UD612250 & 66.2 & 0 & 910 & 2444 & 625 & 65 \\
\hline UDD8337 & UD612249 & 67.2 & 0 & 1456 & 2271 & 528 & 51 \\
\hline UDD8337 & UD612248 & 68.2 & 0 & 1355 & 1940 & 524 & 60 \\
\hline UDD8337 & UD612247 & 69.2 & 0 & 1523 & 2032 & 609 & 68 \\
\hline UDD8337 & UD612246 & 70.2 & 0.01 & 1035 & 3289 & 517 & 66 \\
\hline UDD8337 & UD612245 & 71.2 & 0 & 1111 & 2396 & 667 & 65 \\
\hline UDD8337 & UD612244 & 72.2 & 0 & 1497 & 4510 & 604 & 73 \\
\hline UDD8337 & UD612243 & 73.2 & 0 & 1326 & 2767 & 508 & 53 \\
\hline UDD8337 & UD612242 & 74.2 & 0 & 1193 & 2742 & 623 & 55 \\
\hline UDD8337 & UD612241 & 75.2 & 0 & 1914 & 1880 & 550 & 59 \\
\hline UDD8337 & UD612240 & 76.2 & 0.01 & 1784 & 2759 & 535 & 69 \\
\hline UDD8337 & UD612239 & 76.8 & 0.06 & 1671 & 2967 & 580 & 60 \\
\hline UDD8337 & UD612238 & 77.8 & 0.01 & 1499 & 3533 & 444 & 66 \\
\hline UDD8337 & UD612237 & 78.8 & 0 & 2493 & 2537 & 363 & 81 \\
\hline UDD8337 & UD612235 & 79.7 & 4.58 & 4969 & 4129 & 484 & 67 \\
\hline UDD8337 & UD612234 & 80.7 & 0.92 & 4774 & 3963 & 309 & 85 \\
\hline UDD8337 & UD612233 & 81.2 & 1.98 & 5299 & 4315 & 304 & 68 \\
\hline UDD8337 & UD612232 & 82.2 & 0.46 & 3129 & 2784 & 283 & 68 \\
\hline UDD8337 & UD612231 & 83.2 & 0.28 & 1329 & 2979 & 352 & 66 \\
\hline UDD8337 & UD612230 & 84.2 & 0.01 & 1523 & 2097 & 271 & 67 \\
\hline UDD8337 & UD612229 & 85.2 & 0 & 1657 & 3532 & 462 & 75 \\
\hline UDD8337 & UD612228 & 86.2 & 0 & 1797 & 2998 & 336 & 69 \\
\hline UDD8337 & UD612227 & 87 & 0 & 1387 & 2506 & 384 & 74 \\
\hline UDD8337 & UD612226 & 88 & 0.05 & 1303 & 1813 & 362 & 61 \\
\hline
\end{tabular}




\begin{tabular}{|c|c|c|c|c|c|c|c|}
\hline Drill Hole & Sample & Depth (m) & Au (ppm) & K (ppm) & $\mathrm{Ti}$ (ppm) & $\mathrm{Cr}$ (ppm) & $\mathbf{Z r}(\mathbf{p p m})$ \\
\hline UDD8337 & UD612225 & 89 & 0.13 & 1723 & 3141 & 292 & 77 \\
\hline UDD8337 & UD612224 & 90 & 0.07 & 1216 & 3080 & 349 & 68 \\
\hline UDD8337 & UD612223 & 91 & 0.02 & 1995 & 3229 & 409 & 73 \\
\hline UDD8337 & UD612222 & 92 & 0.68 & 1332 & 1551 & 351 & 73 \\
\hline UDD8337 & UD612221 & 93 & 0.06 & 2701 & 3299 & 421 & 74 \\
\hline UDD8337 & UD612220 & 93.5 & 0.01 & 1192 & 3666 & 380 & 81 \\
\hline UDD8337 & UD612219 & 94.5 & 0.18 & 1573 & 3433 & 383 & 58 \\
\hline UDD8337 & UD612218 & 95.5 & 0.28 & 1502 & 1581 & 224 & 63 \\
\hline UDD8337 & UD612217 & 96.5 & 0 & 1366 & 2557 & 397 & 76 \\
\hline UDD8337 & UD612216 & 97.5 & 0.01 & 1260 & 2770 & 365 & 54 \\
\hline UDD8337 & UD612214 & 98.5 & 0 & 972 & 3505 & 396 & 85 \\
\hline UDD8337 & UD612213 & 99.5 & 0 & 1733 & 4402 & 395 & 66 \\
\hline UDD8337 & UD612212 & 100 & 0.01 & 2733 & 1810 & 357 & 69 \\
\hline UDD8337 & UD612211 & 101 & 0 & 1519 & 3023 & 376 & 65 \\
\hline UDD8337 & UD612210 & 102 & 0.03 & 1082 & 2557 & 455 & 59 \\
\hline UDD8337 & UD612209 & 103 & 0.02 & 2021 & 2249 & 367 & 68 \\
\hline UDD8337 & UD612208 & 104 & 0 & 1226 & 2358 & 415 & 69 \\
\hline UDD8337 & UD612207 & 104.35 & 0 & 2482 & 3565 & 517 & 85 \\
\hline UDD8337 & UD612206 & 105 & 0 & 1524 & 1189 & 379 & 55 \\
\hline UDD8337 & UD612205 & 105.4 & 0 & 1977 & 2352 & 366 & 63 \\
\hline UDD8337 & UD612204 & 106.4 & 0.04 & 1637 & 2411 & 443 & 63 \\
\hline UDD8337 & UD612203 & 107.4 & 0.02 & 917 & 3254 & 398 & 63 \\
\hline UDD8337 & UD612202 & 108.4 & 0.21 & 1785 & 2909 & 455 & 74 \\
\hline UDD8337 & UD612201 & 109.4 & 0.15 & 2119 & 1985 & 430 & 57 \\
\hline UDD8337 & UD612200 & 110.4 & 0 & 1043 & 3301 & 464 & 58 \\
\hline UDD8337 & UD612199 & 111 & 0.01 & 1808 & 3202 & 423 & 64 \\
\hline UDD8337 & UD612198 & 112 & 0 & 1695 & 2176 & 469 & 54 \\
\hline UDD8337 & UD612197 & 113 & 0.04 & 2283 & 2349 & 439 & 57 \\
\hline UDD8337 & UD612196 & 114 & 0.06 & 3021 & 2121 & 393 & 60 \\
\hline UDD8337 & UD612195 & 115 & 0 & 2896 & 2455 & 499 & 62 \\
\hline- & n.a.* & 116 & n.a. & n.a. & n.a. & n.a. & n.a. \\
\hline- & n.a.* & 117 & n.a. & n.a. & n.a. & n.a. & n.a. \\
\hline- & n.a.* & 118 & n.a. & n.a. & n.a. & n.a. & n.a. \\
\hline - & n.a.* & 119 & n.a. & n.a. & n.a. & n.a. & n.a. \\
\hline UDD8334 & UD611975 & 120 & 0 & 2963 & 2281 & 140 & 63 \\
\hline UDD8334 & UD611976 & 121 & 0 & 1693 & 2728 & n.d. & 63 \\
\hline UDD8334 & UD611977 & 122 & 0 & 1726 & 2912 & n.d. & 67 \\
\hline UDD8334 & UD611978 & 123 & 0 & 4140 & 2324 & n.d. & 60 \\
\hline UDD8334 & UD611979 & 124 & 0 & 3105 & 3131 & 159 & 62 \\
\hline UDD8334 & UD611980 & 124.5 & 0 & 3178 & 2836 & n.d. & 64 \\
\hline UDD8334 & UD611981 & 125.2 & 0.04 & 4836 & 1955 & 141 & 58 \\
\hline UDD8334 & UD611982 & 126 & 0.08 & 3586 & 2971 & n.d. & 58 \\
\hline UDD8334 & UD611983 & 126.6 & 0.51 & 6561 & 2919 & n.d. & 60 \\
\hline UDD8334 & UD611985 & 127 & 1.28 & 6617 & 2888 & 174 & 62 \\
\hline UDD8334 & UD611987 & 127.9 & 0.01 & 3529 & 3302 & 173 & 67 \\
\hline UDD8334 & UD611988 & 128.55 & 0 & 1105 & 2634 & n.d. & 58 \\
\hline UDD8334 & UD611989 & 129 & 0 & 3408 & 3722 & n.d. & 77 \\
\hline UDD8334 & UD611990 & 130 & 0 & 3631 & 5578 & 230 & 178 \\
\hline UDD8334 & UD611991 & 131 & 0 & 3214 & 6790 & 290 & 220 \\
\hline UDD8334 & UD611992 & 131.3 & 0 & 5604 & 2821 & n.d. & 64 \\
\hline UDD8334 & UD611993 & 131.85 & 0 & 2624 & 2257 & n.d. & 58 \\
\hline UDD8334 & UD611994 & 132.55 & 0.05 & 2544 & 3472 & 183 & 61 \\
\hline UDD8334 & UD611996 & 133.5 & 0.1 & 2708 & 1805 & 181 & 46 \\
\hline UDD8334 & UD611997 & 133.8 & 0 & 2739 & 2726 & n.d. & 69 \\
\hline
\end{tabular}




\begin{tabular}{|c|c|c|c|c|c|c|c|}
\hline Drill Hole & Sample & Depth (m) & Au (ppm) & K (ppm) & $\mathrm{Ti}$ (ppm) & $\mathrm{Cr}$ (ppm) & $\mathbf{Z r}(\mathbf{p p m})$ \\
\hline UDD8334 & UD611998 & 134.6 & 0 & 2307 & 1631 & n.d. & 54 \\
\hline UDD8334 & UD611999 & 135.15 & 0 & 2345 & 2847 & n.d. & 59 \\
\hline UDD8334 & UD612000 & 135.45 & 0.01 & 3199 & 3019 & 149 & 66 \\
\hline UDD8334 & UD612001 & 136 & 0 & 2564 & 3164 & 220 & 62 \\
\hline UDD8334 & UD612002 & 136.7 & 0 & 2598 & 3353 & 200 & 60 \\
\hline UDD8334 & UD612003 & 137 & 0 & 1728 & 2628 & n.d. & 66 \\
\hline UDD8334 & UD612004 & 138 & 0 & 2390 & 3814 & 233 & 63 \\
\hline UDD8334 & UD612005 & 138.5 & 0 & 2588 & 3476 & 226 & 66 \\
\hline UDD8334 & UD612006 & 139.05 & 0 & 4563 & 2552 & 150 & 54 \\
\hline UDD8334 & UD612007 & 139.6 & 0 & 1858 & 2707 & 164 & 67 \\
\hline UDD8334 & UD612008 & 140.4 & 0 & 2326 & 3105 & n.d. & 65 \\
\hline UDD8334 & UD612009 & 141.4 & 0.03 & 1515 & 2284 & n.d. & 55 \\
\hline UDD8334 & UD612010 & 142.4 & 0 & 1526 & 3026 & 183 & 65 \\
\hline UDD8334 & UD612011 & 142.7 & 0 & 1164 & 2498 & 136 & 69 \\
\hline UDD8334 & UD612012 & 143.5 & 0 & 1423 & 2786 & n.d. & 59 \\
\hline UDD8334 & UD612013 & 144.5 & 0 & 2073 & 2576 & 161 & 60 \\
\hline UDD8334 & UD612014 & 145.5 & 0 & 1668 & 2753 & n.d. & 56 \\
\hline UDD8334 & UD612015 & 146.5 & 0 & 1760 & 2328 & n.d. & 61 \\
\hline UDD8334 & UD612017 & 147.5 & 0 & 2429 & 2838 & n.d. & 57 \\
\hline UDD8334 & UD612018 & 148.5 & 0.07 & 2775 & 3131 & n.d. & 70 \\
\hline UDD8334 & UD612019 & 149.35 & 0.08 & 1663 & 4207 & 193 & 65 \\
\hline UDD8334 & UD612020 & 150.1 & 0.38 & 1778 & 4710 & 361 & 72 \\
\hline UDD8334 & UD612021 & 151 & 0.2 & 1056 & 2548 & 159 & 56 \\
\hline UDD8334 & UD612022 & 152 & 0 & 2161 & 2017 & n.d. & 55 \\
\hline UDD8334 & UD612023 & 153 & 0.03 & 2480 & 3314 & n.d. & 57 \\
\hline UDD8334 & UD612024 & 153.75 & 0.06 & 2131 & 3590 & n.d. & 60 \\
\hline UDD8334 & UD612025 & 154.05 & 0.69 & 2431 & 2891 & n.d. & 60 \\
\hline UDD8334 & UD612026 & 155 & 1.15 & 4024 & 3643 & n.d. & 67 \\
\hline UDD8334 & UD612027 & 156 & 0.18 & 4751 & 2967 & n.d. & 61 \\
\hline UDD8334 & UD612028 & 156.35 & 0.27 & 3176 & 2440 & 700 & 45 \\
\hline UDD8334 & UD612029 & 156.8 & 2.68 & 3086 & 3150 & 381 & 66 \\
\hline UDD8334 & UD612030 & 157.5 & 0.08 & 6266 & 4553 & 396 & 71 \\
\hline UDD8334 & UD612031 & 158.1 & 0.56 & 4185 & 4753 & 154 & 75 \\
\hline UDD8334 & UD612032 & 158.8 & 0.03 & 4664 & 3838 & 249 & 74 \\
\hline UDD8334 & UD612033 & 159.25 & 0.06 & 3881 & 3510 & 233 & 82 \\
\hline UDD8334 & UD612034 & 160.2 & 0.12 & 2342 & 4072 & 239 & 68 \\
\hline UDD8334 & UD612035 & 161.1 & 0.15 & 3411 & 4322 & 307 & 88 \\
\hline UDD8334 & UD612037 & 162.1 & 0.17 & 2994 & 3721 & 293 & 63 \\
\hline UDD8334 & UD612038 & 163.05 & 0.39 & 2241 & 3997 & 329 & 78 \\
\hline UDD8334 & UD612040 & 163.6 & 0 & 2561 & 4976 & 253 & 74 \\
\hline UDD8334 & UD612041 & 164 & 0.58 & 2400 & 4516 & 169 & 91 \\
\hline UDD8334 & UD612042 & 165 & 0.05 & n.d. & 4252 & n.d. & 102 \\
\hline UDD8334 & UD612043 & 166 & 0 & n.d. & 5581 & 190 & 100 \\
\hline UDD8334 & UD612044 & 167 & 0.03 & n.d. & 6597 & n.d. & 113 \\
\hline UDD8334 & UD612045 & 168 & 0.03 & 1182 & 6316 & 217 & 106 \\
\hline UDD8334 & UD612046 & 169 & 0 & 1799 & 6107 & n.d. & 87 \\
\hline UDD8334 & UD612047 & 170 & 0.43 & 2563 & 6171 & n.d. & 91 \\
\hline UDD8334 & UD612048 & 170.4 & 0.16 & 1330 & 1836 & n.d. & 77 \\
\hline UDD8334 & UD612049 & 170.8 & 0.03 & n.d. & n.d. & 3560 & 13 \\
\hline UDD8334 & UD612050 & 171.2 & 0.05 & 1247 & 1300 & 2610 & 35 \\
\hline UDD8334 & UD612051 & 172 & 0.08 & 1129 & 5395 & 207 & 96 \\
\hline UDD8334 & UD612052 & 172.5 & 0.04 & 1569 & 6572 & n.d. & 109 \\
\hline UDD8334 & UD612053 & 173.4 & 0 & 1487 & 5222 & 257 & 98 \\
\hline UDD8334 & UD612054 & 174 & 0 & 1067 & 5917 & 183 & 102 \\
\hline
\end{tabular}




\begin{tabular}{|c|c|c|c|c|c|c|c|}
\hline Drill Hole & Sample & Depth (m) & Au (ppm) & K (ppm) & Ti (ppm) & Cr (ppm) & Zr (ppm) \\
\hline UDD8334 & UD612055 & 175 & 0 & 1177 & 6353 & 176 & 100 \\
\hline
\end{tabular}




\section{APPENDIX 2: Mafic discrimination diagrams}

(a)

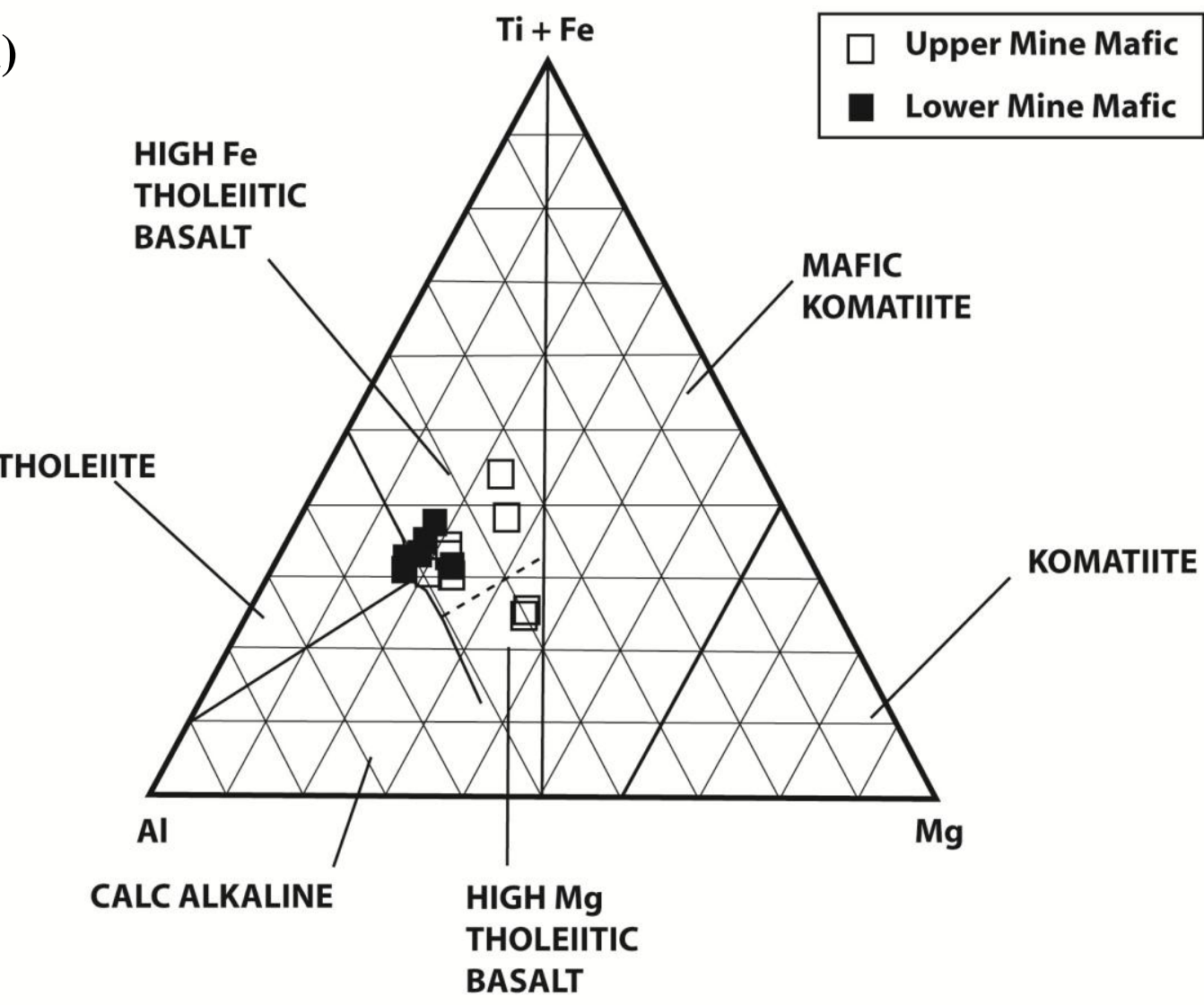

(b)

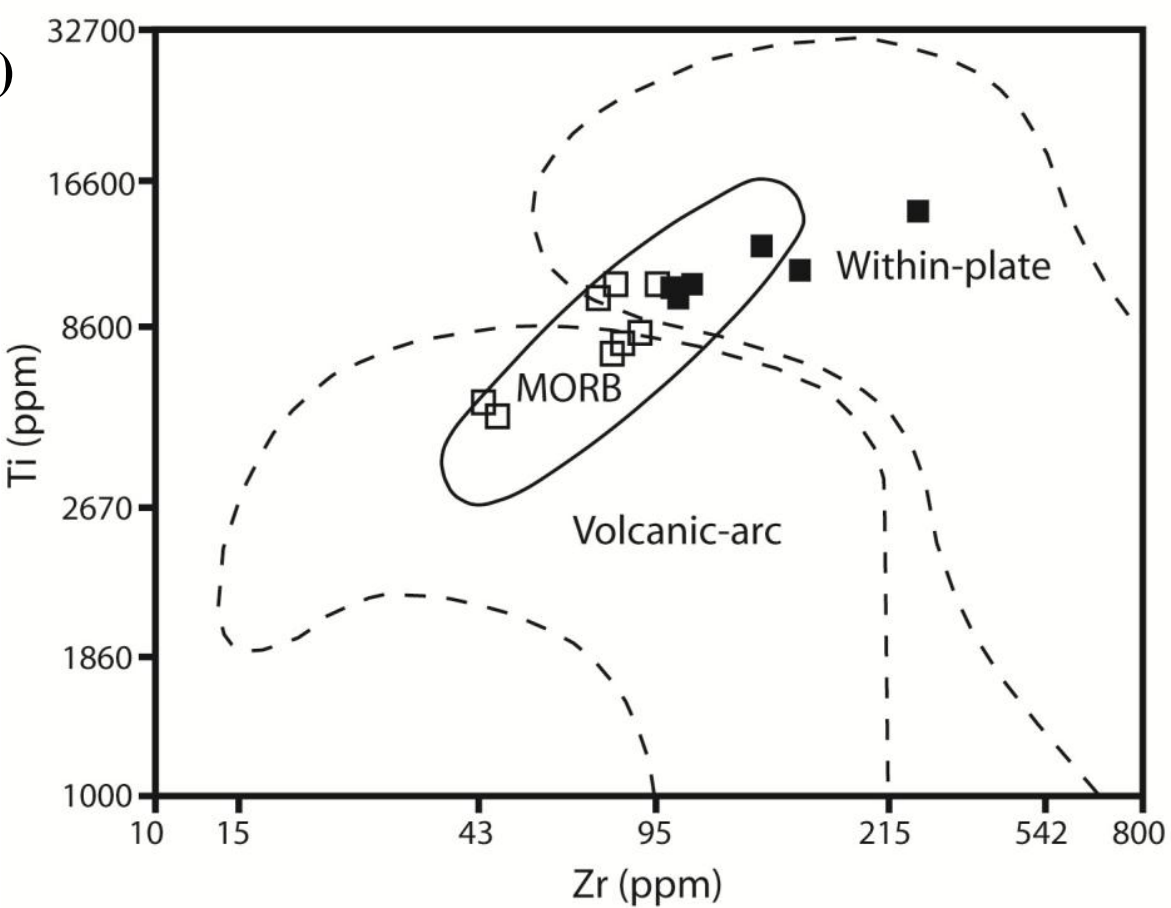

Figure A2. (a) Jensen diagram for samples from the Mine Mafic Package showing compositions are predominantly high-Fe tholeiite (after Morgan (2004)); (b) Ti vs Zr diagram showing the rocks of the Mine Mafic Package are MORB in composition and cover both the volcanic-arc and in-plate fields (after Morgan (2004)). 


\section{APPENDIX 3: Portable XRF workflow}

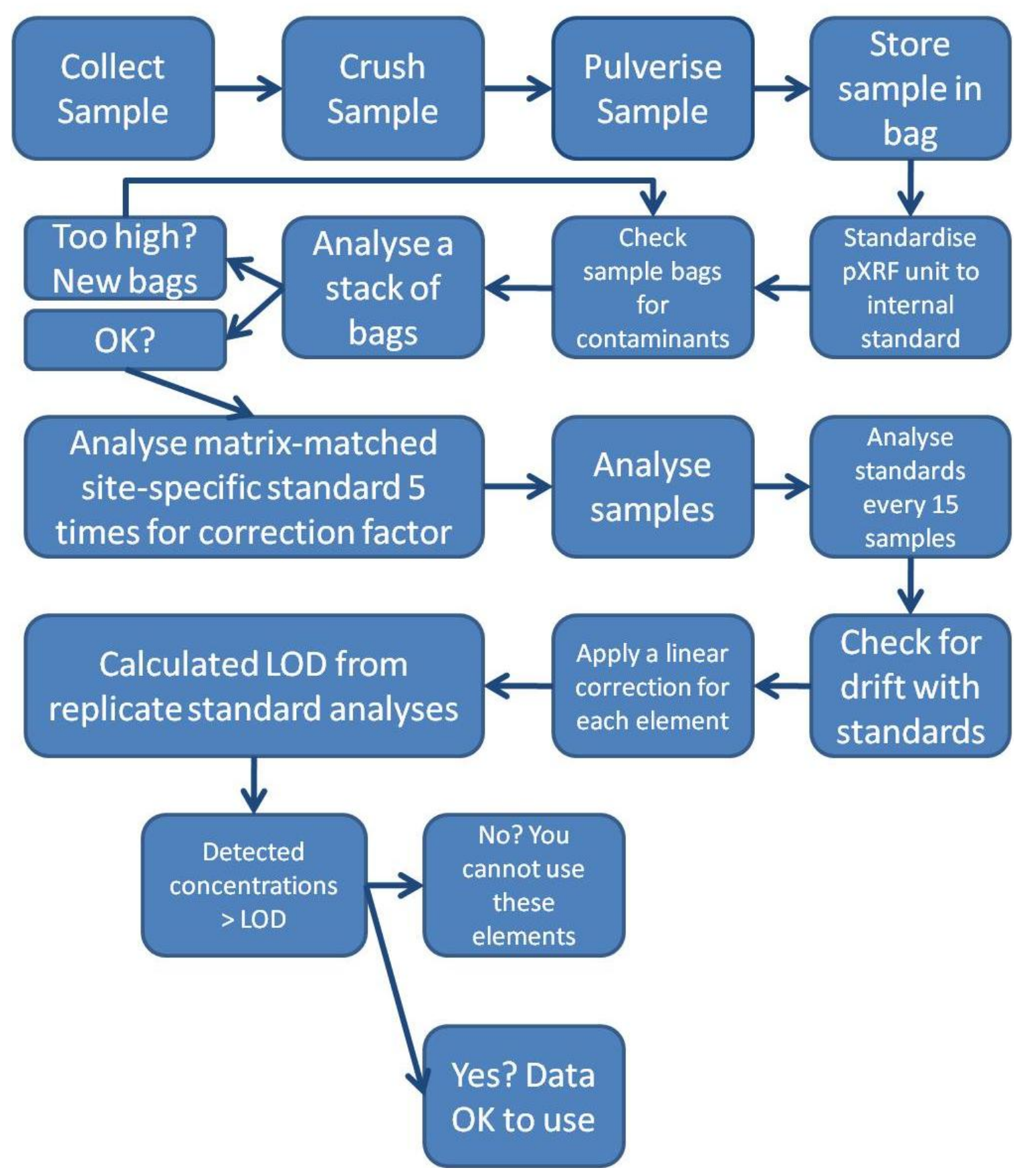




\section{APPENDIX 4: Geochemical techniques}

\section{Pb-isotopes}

\section{Digestion of samples}

1. Once a mineral separate was prepared by hand-picking under a stereo microscope, it was stored in sterile vial.

2. The sample was transferred to a $7 \mathrm{ml} \mathrm{Savillex}{ }^{\circledR}$ Teflon $^{\circledR}$ beaker and weighed.

3. The sample was cleaned three times in its beaker with Milli-Q water ${ }^{13}$ (MQ) by shaking - the water was pipetted off and replaced with new water between each wash.

4. As much MQ as possible was pipetted off before the acid was applied.

5. $\sim 1 \mathrm{ml}$ of concentrated $\mathrm{HF}$ and 5 drops of concentrated $\mathrm{HNO}_{3}$ were added to each sample and left on a hot plate at $\sim 120^{\circ} \mathrm{C}$ for 24 hours and then dried down. ${ }^{14}$

6. $\sim 1 \mathrm{ml}$ of concentrated $\mathrm{HNO}_{3}$ was added and dried down immediately, this step was repeated, to remove any traces of fluorides.

7. $2 \mathrm{ml}$ of $\sim 0.8 \mathrm{M} \mathrm{HBr}$ was added to each sample and dried down.

8. Samples were dried down, capped, and stored until column chemistry was to occur.

\section{Column chemistry}

1. While setting up columns $2 \mathrm{ml}$ of $\sim 0.8 \mathrm{M} \mathrm{HBr}$ was added to each evaporated sample to take it up into solution. Samples were centrifuged for $\sim 3$ minutes at $2000 \mathrm{rpm}$ to separate any remaining solids from them.

\footnotetext{
${ }^{13}$ Milli-Q water is deionised water that has been purified so that it has a resistivity of greater than 18.2 $\mathrm{M} \Omega$ at $25^{\circ} \mathrm{C}$.

${ }^{14}$ Note: All concentrated acids used for $\mathrm{Pb}$ separation in this study were Seastar and have $\mathrm{Pb}$ concentrations $<5$ ppt.
} 
2. Columns consisted of $1 \mathrm{ml}$ Eppendorf ${ }^{\circledR}$ pipette tip with a frit in it. They were removed from $6 \mathrm{M} \mathrm{HCl}$ where they have been stored and put in a column rack.

3. The inside and outside of the columns were washed three times each with MQ. Care was taken to ensure that the meniscus of the MQ was right at the top of the column to ensure the top edge was clean.

4. Approximately $0.5 \mathrm{~cm}$ height of $\mathrm{AG} 1 \mathrm{X} 8$ anion exchange resin was loaded into each column.

5. Column and resin were washed with three washes of $6 \mathrm{M} \mathrm{HCl}$ and $\mathrm{MQ}$ alternating; starting with the $\mathrm{HCl}$.

6. $\sim 0.8 \mathrm{M} \mathrm{HBr}$ was loaded onto each column and allowed to run through the resin to condition it.

7. The sample was loaded into each column. The pipette tip used to load each sample was first washed in MQ and $\sim 0.8 \mathrm{M} \mathrm{HBr}$, and a new pipette tip was used for each sample.

8. Once loaded with the sample, each column was washed through with three washes of $\sim 0.8 \mathrm{M} \mathrm{HBr}$ to remove matrix elements.

9. While the three $\sim 0.8 \mathrm{M} \mathrm{HBr}$ washes were dripping through the columns, the beakers that the samples came from were washed rinsed using MQ, tipping it out three times, and washed twice by half filling them with MQ, by putting the lid on and shaking them.

10. To collect the $\mathrm{Pb}$ from the column, two columns full of $6 \mathrm{M} \mathrm{HCl}$ were collected in the same (cleaned) beaker that each sample came from.

11. Each sample was dried on a hot plate over-night.

12. $1 \mathrm{ml}$ of conc. $\mathrm{HNO}_{3}$ was added and dried down immediately.

13. Beakers were capped and stored until analysis. 
MC-ICP-MS analysis protocol:

1. Evaporated samples were taken into solution with $0.5 \% \mathrm{HNO}_{3}$ on a hot plate for around $1 \mathrm{hr}$.

2. $10 \mu \mathrm{l}$ of sample pipetted into a new, clean beaker and $\sim 4 \mathrm{ml}$ of $0.5 \% \mathrm{HNO}_{3}$ added. The beaker was capped and shaken to mix.

3. Sample solutions were introduced into MC-ICP-MS through a Nu Instruments desolvating nebuliser system, DSN-100.

4. Signal voltage for mass ${ }^{208} \mathrm{~Pb}$ was monitored and either more sample or dilutant acid added to $\mathrm{HNO}_{3}$ solution until $\sim 4-5 \mathrm{kV}{ }^{208} \mathrm{~Pb}$ signal obtained.

5. SRM 981was used to tune the MC-ICP-MS.

6. Instrumental mass bias was corrected for by sample-standard bracketing using SRM981.

7. Wash out between each sample and standard was done using $0.5 \% \mathrm{HNO}_{3}$, followed by on peak zero (OPZ) solution. ${ }^{208} \mathrm{~Pb}$ counts were monitored, until a signal of $<10^{-3} \mathrm{~V}$ was reached.

8. The baseline was then analysed in OPZ $0.5 \%$ prior to each standard and sample analysis.

9. The sample or standard were introduced and the counts on $\mathrm{Pb}^{208}$ monitored until the signal stabilised (ideally $\sim 3-5 \mathrm{kV}$ ).

10. Unknowns were bracketed with SRM981 to ensure that a fractionation correction could be applied to correct for analytical drift during the analysis run.

11. Results were recorded, printed out, and the fractionation correction applied. 


\section{$R b-S r$ isotopes}

\section{Digestion of samples}

1. Once a mineral separate was prepared by hand-picking under a stereo microscope, it was stored in sterile vial.

2. Mineral separates were transferred to a $7 \mathrm{ml}$ Savillex ${ }^{\circledR}$ Teflon ${ }^{\circledR}$ beaker and weighed.

3. Approximately 50-60 mg sub-samples of pulverised whole rock powder for each sample was also weighed into $7 \mathrm{ml} \mathrm{Savillex}{ }^{\circledR}$ Teflon ${ }^{\circledR}$ beakers.

4. $\sim 1 \mathrm{ml}$ of concentrated $\mathrm{HF}$ and 5 drops of concentrated $\mathrm{HNO}_{3}$ were added to each sample (either mineral separate or whole rock powder) and left on a hot plate at $120{ }^{\circ} \mathrm{C}$ for 24 hours and then dried down.

5. $\sim 1 \mathrm{ml}$ of concentrated $\mathrm{HNO}_{3}$ was added and dried down immediately, this step was repeated.

6. Samples were stored, capped, and dried down until column chemistry was to occur.

\section{Column chemistry}

1. Samples were taken into solution in $2 \mathrm{ml}$ of $3 \mathrm{M} \mathrm{HNO}_{3}$ on a hot plate.

2. A $0.2 \mathrm{ml}$ aliquot of each sample was taken and stored in a vial that had been soaking in $3 \mathrm{M} \mathrm{HCl}$ for an extended period; these were washed three times with MQ before use.

3. Columns were removed from $1-2 \mathrm{M} \mathrm{HCl}$ where they have been stored and put in a column rack. Columns consisted of $1 \mathrm{ml}$ Eppendorf ${ }^{\circledR}$ pipette tip with a frit in it. 
4. The inside and outside of the columns were washed three times each with MQ. Care was taken to ensure that the meniscus of the MQ was right at the top of the column to ensure the top edge is clean.

5. Approximately $5 \mathrm{~mm}$ height of Sr-SPEC exchange resin was loaded into each column.

6. Column and resin were washed with one wash of $3 \mathrm{M} \mathrm{HNO}_{3}$, one wash of $\mathrm{MQ}$ and finally one more wash of $3 \mathrm{M} \mathrm{HNO}_{3}$.

7. $1.8 \mathrm{ml}$ of sample was loaded into each column; the pipette tip was first washed in $3 \mathrm{M} \mathrm{HNO}_{3}$, and a new pipette tip was used for each sample.

8. Once loaded with the sample, each column was washed through with two halfvolumes of $3 \mathrm{M} \mathrm{HNO}_{3}$.

9. While the two $\mathrm{HNO}_{3}$ washes were dripping through the columns, the beakers that the samples came from were washed rinsed using MQ, tipping it out three times, and washed once by half filling them with MQ, by putting the lid on and shaking them. Once washed with MQ, $1-2 \mathrm{ml}$ of $6 \mathrm{M} \mathrm{HCl}$ was put in each beaker and placed on a hot plate until they were needed to collect the sample from the columns. Before collecting the samples, the beakers were again washed three times with MQ.

10. To collect the Sr from the column, two almost full columns of MQ were collected in the same (cleaned) beaker that each sample came from.

11. Each sample was dried on a hot plate.

12. While the samples were being dried down, a new set of columns were prepared for the second pass following steps 3 through 10, and left to dry down before being capped until analysis. 
MC-ICP-MS analysis protocol for Sr isotopes

1. Evaporated samples taken into solution with $0.5 \% \mathrm{HNO}_{3}$ on a hot plate for $\sim 1 \mathrm{hr}$.

2. $10 \mu \mathrm{l}$ of sample pipetted into a beaker and $\sim 4 \mathrm{ml}$ of $0.5 \% \mathrm{HNO}_{3}$ added. The beaker was capped and shaken to mix.

3. Sample solutions introduced into MC-ICP-MS through $\mathrm{Nu}$ Instruments desolvating nebuliser system.

4. Signal voltage for mass ${ }^{88} \mathrm{Sr}$ was monitored and either more sample or dilutant acid added to $\mathrm{HNO}_{3}$ mixture until $\sim 4-5 \mathrm{kV}{ }^{88} \mathrm{Sr}$ signal obtained.

5. SRM 987 was used to tune the MC-ICP-MS.

6. Wash out between each sample and standard using $0.5 \% \mathrm{HNO}_{3}$ until a signal of < $10^{-4} \mathrm{~V}$ was reached.

7. The sample or standard were introduced and the counts on ${ }^{88} \mathrm{Sr}$ monitored until the signal stabilised (ideally $\sim 3-5 \mathrm{kV}$ ).

8. Typical sequence of analysis was: SRM987, sample, sample, BHVO-2, sample, sample, SRM987.

9. Results were recorded, printed out, and the fractionation correction applied.

\section{ICP-MS protocol for $\mathrm{Rb} / \mathrm{Sr}$ ratio}

1. Samples were prepared as outlined above.

2. They were on an Agilent 7500CS ICP-MS.

3. Washout between samples was $60 \mathrm{~s}$.

4. Background count rates were measured for $60 \mathrm{~s}$ prior to each sample on an analytical blank and the mean background was subtracted directly from the sample count rates measured.

5. Samples were introduced into the ICP-MS via a wet spray chamber. 
6. Analyses were conducted for $120 \mathrm{~s}$.

7. They were analysed using a 1:1 solution of $\mathrm{Rb} / \mathrm{Sr}$ as a standard, given the expected $\mathrm{Rb} / \mathrm{Sr}$ ratios to be measured. 


\section{$P b-P b$ analyses of sphene by LA-ICP-MS}

1. A thick-section block of the sample was cut to a size of about $1 \mathrm{~cm}$ by $0.5 \mathrm{~cm}$ and mounted in a circular mount with a shard of NIST610.

2. The epoxy mount was prepared by grinding using wet $400-4000 \mu \mathrm{m}$ grit silicon carbide paper followed by successive lap polishing using $3 \mu \mathrm{m}$ and $1 \mu \mathrm{m}$ liquid diamond suspensions.

3. Analyses were conducted using a New Wave deep ultraviolet (193 nm solid state) laser ablation system coupled to a Agilent 7500CS ICP-MS.

4. Lead isotopic data were corrected using the ${ }^{208} \mathrm{~Pb} /{ }^{206} \mathrm{~Pb}$ ratio measured on the NIST610 standard with respect to the reference value given by Baker et al. (2004) using the exponential mass fractionation law. 


\section{APPENDIX 5: Sample locations}

NB: Other sample locations for those samples utilised for compiling the geochemical stratigraphy, are shown, along with their pXRF analysis in Appendix 1.

\begin{tabular}{|c|c|c|c|c|}
\hline Sample \# & Description of sample & Location & Depth if drill hole (m) & Uses \\
\hline MG004 & High-grade cherty lode & WD 2165 Airleg & & TS, WR \\
\hline MG024 & High-grade cherty lode & TV 2310 NOD & & TS, WR \\
\hline MG025 & Qtz-cal-po-ccp (Bintang Fault) & TV 1820 SOD Pillar & & $\mathrm{ThS}, \mathrm{Pb}$ \\
\hline MG026 & Grt-bearing mafic & UDD8252 & 7.10 & TS, WR \\
\hline MG027 & Grt-bearing mafic & UDD8252 & 7.10 & TS, WR \\
\hline MG034 & High-grade muscovite-rich lode & VD1925 EOD & & TS, WR, Rb-Sr, Pb \\
\hline MG039 & Massive po from UM-Mafic contact & TD 3810 EOD & & $\mathrm{TS}, \mathrm{Pb}$ \\
\hline MG053 & Metabasalt & UDD1484 & 268.10 & TS, WR \\
\hline MG138 & Garnetiferous metachert & UDD7665 & 214.20 & TS, WR \\
\hline MG200 & Garnetiferous mafic & UDD7085 & 87.30 & TS, WR \\
\hline MG201 & Qtz-po-ccp (Bintang Fault) & TV 1820 SOD Pillar & & ThS, WR \\
\hline MG218 & Qtz-po-Au & ND 2626 SOD F11 & & $\mathrm{ThS}, \mathrm{Pb}$ \\
\hline MG222 & Timor brown lode & TV 2419 NOD & & $\mathrm{TS}, \mathrm{Pb}$ \\
\hline MG224 & Timor brown lode & TV 2121 SOD & & $\mathrm{TS}, \mathrm{Pb}$ \\
\hline MG233 & High-grade brown lode with Po-Au & BD 3523 NXC F01 & & $\mathrm{TS}, \mathrm{Rb}-\mathrm{Sr}, \mathrm{Pb}$ \\
\hline MG308 & Metabasalt & UDD1417 & 309.25 & TS, WR \\
\hline MG309 & Metabasalt & UDD1417 & 305.10 & TS, WR \\
\hline MG310 & Metabasalt & UDD1417 & 287.75 & TS, WR \\
\hline MG311 & Metabasalt & UDD1730B & 346.90 & TS, WR \\
\hline MG312 & Metabasalt & UDD1730B & 348.65 & TS, WR \\
\hline MG313 & Metabasalt & UDD1730B & 350.00 & TS, WR, FeO \\
\hline MG314 & High grade lode & UDD1417 & 217.60 & TS, WR \\
\hline MG327 & Garnetiferous mafic & UDD1886 & $178.00-178.50$ & TS, WR \\
\hline MG345 & Metabasalt & UDD7085 & 63.30 & TS, WR \\
\hline MG346 & Metabasalt & UDD7085 & 65.80 & TS, WR \\
\hline MG347 & Metabasalt & UDD7085 & 80.20 & TS, WR \\
\hline MG348 & Metabasalt & UDD8334 & 53.30 & TS, WR \\
\hline MG349 & Metabasalt & UDD8334 & 53.90 & TS, WR \\
\hline MG350 & Metabasalt & UDD8334 & 54.40 & TS, WR \\
\hline MG351 & Metabasalt & UDD8337 & 76.40 & TS, WR \\
\hline MG352 & Metabasalt & UDD8337 & 78.30 & TS, WR \\
\hline MG353 & Metabasalt & UDD8337 & 82.10 & TS, WR \\
\hline MG354 & Cal-chl-spn vein & MD 3211 EOD & & ThS, Pb-Pb \\
\hline
\end{tabular}

$\mathrm{TS}=$ Thin section; $\mathrm{ThS}=$ Thick Section; $\mathrm{Fe}=\mathrm{FeO}$ determination; $\mathrm{WR}=$ Whole rock; $\mathrm{Pb}=\mathrm{Pb}$ isotope model age; $\mathrm{Pb}-\mathrm{Pb}=\mathrm{Pb}-\mathrm{Pb}$ age; $\mathrm{Rb}-\mathrm{Sr}=\mathrm{Rb}-\mathrm{Sr}$ age; Mineral abbreviations after Kretz (1983). 


\begin{tabular}{l|l} 
Sample \# & Description of sample \\
MG800 & Asp from TV2310 NOD Airleg \\
MG801 & Qtz-sph (Harp fault) \\
MG802 & Qtz-pyr-Au vein \\
TF02 & Lode in low-strain zone \\
TF06 & Lode in low-strain zone \\
TF08 & Altered wall rock - amphibolite \\
TF10 & Wall rock - amphibolite \\
TF12 & Wall rock - amphibolite
\end{tabular}

\begin{tabular}{|l} 
Location \\
TV 2310 NOD Airleg \\
CI2710 \\
MD 2933 WOD \\
TF1720 \\
TF1720 \\
TF1720 \\
TF1720 \\
TF1720
\end{tabular}

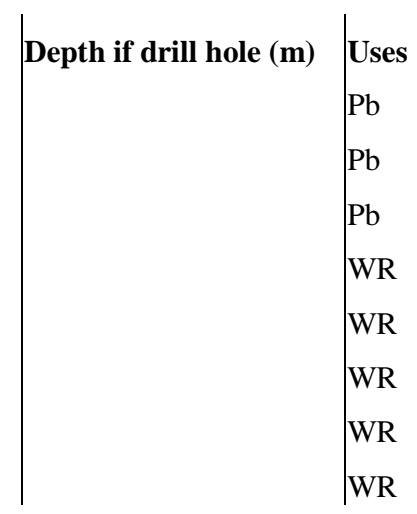

$\mathrm{TS}=$ Thin section; $\mathrm{ThS}=$ Thick Section $; \mathrm{Fe}=\mathrm{FeO}$ determination; $\mathrm{WR}=$ Whole rock $\mathrm{Pb}=\mathrm{Pb}$ isotope model age; $\mathrm{Pb}-\mathrm{Pb}=\mathrm{Pb}-\mathrm{Pb}$ age; $\mathrm{Rb}-\mathrm{Sr}=\mathrm{Rb}-\mathrm{Sr}$ age; Mineral abbreviations after Kretz (1983). 


\section{APPENDIX 6: Whole rock analyses}

\begin{tabular}{|c|c|c|c|c|c|c|c|c|c|c|c|c|}
\hline 2 & MG004 & MG024 & MG026 & MG027 & MG034 & MG053 & MG138 & MG200 & MG308 & MG309 & MG310 & MG311 \\
\hline $\mathrm{SiO}_{2}$ & 56.11 & 53.79 & 54.33 & 50.52 & 55.96 & 53.79 & 49.28 & 33.05 & 48.58 & 48.88 & 50.64 & 49.29 \\
\hline $\mathrm{T}_{2} \mathrm{O}_{3}$ & 0.81 & 0.85 & 0.84 & 0.25 & 0.44 & 0.89 & 0.43 & 0.95 & 1.35 & 1.27 & 1.53 & 0.68 \\
\hline $\mathrm{Al}_{2} \mathrm{O}_{3}$ & 13.14 & 12.23 & 14.47 & 9.91 & 10.32 & 14.97 & 13.27 & 18.88 & 15.53 & 14.74 & 13.66 & 14.80 \\
\hline Fe $\mathrm{O}$ & 10.59 & 11.37 & 14.16 & 22.40 & 13.11 & 10.80 & 20.95 & 22.58 & 12.44 & $11.38^{\#}$ & 13.47 & 11.58 \\
\hline $\mathrm{MnO}$ & 0.10 & 0.11 & 0.27 & 0.80 & 0.02 & 0.16 & 0.41 & 0.42 & 0.21 & 0.21 & 0.21 & 0.19 \\
\hline MgO & 4.07 & 4.08 & 3.98 & 5.82 & 1.89 & 5.25 & 6.43 & 9.82 & 5.57 & 5.71 & 5.89 & 9.08 \\
\hline $\mathrm{Ca}_{2} \mathrm{O}$ & 3.57 & 4.75 & 8.58 & 7.94 & 1.36 & 9.48 & 4.88 & 6.80 & 10.91 & 11.80 & 10.05 & 10.68 \\
\hline $\mathrm{Na}_{2} \mathrm{O}$ & 3.24 & 2.65 & 2.46 & 0.73 & 1.00 & 2.74 & 0.68 & 0.92 & 2.57 & 2.81 & 3.41 & 2.44 \\
\hline K $\mathbf{3}$ & 1.40 & 1.58 & 0.41 & 0.26 & 2.64 & 0.26 & 0.61 & 0.65 & 0.22 & 0.19 & 0.28 & 0.28 \\
\hline $30^{5}$ & 0.04 & 0.08 & $<0.01$ & 0.72 & 0.03 & 0.01 & 0.27 & 0.68 & 0.91 & 1.06 & 0.23 & $<0.01$ \\
\hline P O & 0.06 & 0.07 & 0.09 & 0.06 & 0.02 & 0.15 & 0.17 & 0.09 & 0.14 & 0.12 & 0.12 & 0.07 \\
\hline LOI & 4.82 & 6.61 & 0.08 & -0.05 & 12.57 & 1.41 & 2.39 & 4.53 & 0.94 & 1.29 & 0.29 & 0.73 \\
\hline SUM & 97.95 & 99.38 & 99.67 & 99.37 & 99.35 & 99.91 & 99.77 & 99.38 & 99.36 & 99.45 & 99.77 & 99.82 \\
\hline $\mathbf{S}$ & 0.01 & 0.01 & 0.00 & 0.01 & 0.01 & n.a. & 0.00 & 0.00 & 0.00 & 0.00 & 0.00 & 0.00 \\
\hline As & $3.0 \% *$ & $3.8 \% *$ & 25 & 5 & $7.2 \% *$ & n.a. & 11 & 11 & 11 & 2 & 15 & 2 \\
\hline Ba & 339 & 330 & 82 & 39 & 321 & n.a. & 219 & 77 & 36 & 34 & 107 & 44 \\
\hline $\mathrm{Ce}$ & 17 & 14 & 18 & 39 & 8 & n.a. & 64 & 16 & 25 & 19 & 25 & $<5$ \\
\hline $\mathrm{Cr}$ & 110 & 112 & 138 & 31 & 803 & n.a. & 39 & 918 & 273 & 266 & 114 & 555 \\
\hline $\mathrm{Cu}$ & 135 & 101 & 29 & 163 & 37 & n.a. & 87 & 196 & 14 & 34 & 88 & 59 \\
\hline Ga & 24 & 17 & 15 & 15 & 15 & n.a. & 22 & 23 & 20 & 19 & 18 & 16 \\
\hline La & $<5$ & 13 & 10 & $<5$ & 7 & n.a. & 38 & $<5$ & $<5$ & $<5$ & 14 & 7 \\
\hline Nb & $<1$ & $<1$ & $<1$ & $<1$ & $<1$ & n.a. & $<1$ & $<1$ & $<1$ & $<1$ & 7 & $<1$ \\
\hline $\mathbf{N i}$ & 34 & 44 & 37 & 22 & 152 & n.a. & 23 & 140 & 110 & 100 & 135 & 153 \\
\hline $\mathbf{P b}$ & 29 & 22 & 7 & 7 & 38 & n.a. & 9 & 8 & 10 & 12 & 5 & 3 \\
\hline $\mathbf{R b}$ & 45 & 41 & 6 & 3 & 57 & n.a. & 21 & 14 & 2 & 4 & 2 & 6 \\
\hline Sc & 39 & 36 & 33 & 7 & 31 & n.a. & 9 & 41 & 39 & 34 & 26 & 37 \\
\hline $\mathrm{Sr}$ & 89 & 73 & 158 & 15 & 32 & n.a. & 22 & 56 & 157 & 167 & 357 & 143 \\
\hline Th & 96 & 130 & $<1$ & 8 & $<1$ & n.a. & 9 & 2 & 2 & $<1$ & $<1$ & $<1$ \\
\hline $\mathbf{U}$ & $<1$ & $<1$ & $<1$ & 3 & $<1$ & n.a. & 4 & 2 & $<1$ & $<1$ & 1 & $<1$ \\
\hline V & 254 & 248 & 227 & 28 & 168 & n.a. & 66 & 297 & 297 & 280 & 256 & 216 \\
\hline $\mathbf{Y}$ & 18 & 23 & 20 & 4 & $<1$ & n.a. & 12 & 30 & 26 & 26 & 23 & 20 \\
\hline $\mathbf{Z n}$ & 72 & 57 & 102 & 166 & 30 & n.a. & 360 & 145 & 131 & 119 & 106 & 84 \\
\hline $\mathbf{Z r}$ & 78 & 82 & 89 & 98 & 31 & n.a. & 139 & 98 & 112 & 104 & 108 & 70 \\
\hline
\end{tabular}

Major elemental data are reported in wt \%; trace element data are reported in ppm, except where stated. All samples analysed by Spectrachem Analytical, Lower Hutt, Wellington, New Zealand.

* Data outside calibration range.

$<$ Denotes data below detection limit.

${ }^{\#} \mathrm{Fe}^{2+}$ analysed at Albert-Ludwigs-Universität Freiburg, Germany, by titration: MG309 $=8.47 \%$. 


\begin{tabular}{|c|c|c|c|c|c|c|c|c|c|c|c|c|}
\hline 2 & MG312 & MG313 & MG314 & MG327 & MG345 & MG346 & MG347 & MG348 & MG349 & MG350 & MG351 & MG352 \\
\hline $\mathrm{SiO}_{2}$ & 51.84 & 50.14 & 56.06 & 63.75 & 51.27 & 52.86 & 49.56 & 50.33 & 50.89 & 52.21 & 47.07 & 47.04 \\
\hline $\mathrm{T}_{2} \mathrm{O}_{3}$ & 0.68 & 0.63 & 0.79 & 0.67 & 1.40 & 1.46 & 0.66 & 1.42 & 1.47 & 1.42 & 0.54 & 0.59 \\
\hline $\mathbf{A l}_{2} \mathbf{O}_{3}$ & 14.13 & 13.79 & 12.98 & 16.01 & 13.29 & 13.13 & 15.17 & 13.18 & 13.58 & 13.46 & 12.14 & 13.30 \\
\hline $\mathrm{FeO}$ & 10.49 & 11.06 & 11.32 & 4.91 & 14.11 & 12.17 & 10.63 & 12.17 & 13.77 & 13.90 & 12.11 & 12.49 \\
\hline $\mathrm{MnO}$ & 0.17 & 0.19 & 0.12 & 0.16 & 0.21 & 0.19 & 0.18 & 0.14 & 0.13 & 0.13 & 0.21 & 0.21 \\
\hline $\mathrm{MgO}$ & 7.46 & 9.75 & 3.91 & 0.72 & 6.79 & 5.91 & 7.34 & 5.66 & 6.18 & 6.25 & 12.94 & 11.36 \\
\hline $\mathrm{CaO}$ & 9.53 & 9.98 & 4.89 & 6.54 & 7.05 & 7.67 & 10.36 & 6.39 & 4.28 & 4.21 & 10.89 & 11.47 \\
\hline $\mathrm{Na}_{2} \mathrm{O}$ & 3.21 & 2.54 & 1.59 & 2.77 & 4.44 & 4.81 & 3.12 & 5.44 & 5.50 & 5.44 & 1.48 & 1.63 \\
\hline K 9 & 0.71 & 0.38 & 2.78 & 1.66 & 0.19 & 0.27 & 0.65 & 0.21 & 0.21 & 0.10 & 0.29 & 0.22 \\
\hline $80^{5}$ & 0.23 & 0.06 & 0.19 & 0.16 & $<0.01$ & 0.02 & 0.03 & 0.11 & 0.36 & 0.43 & $<0.01$ & 0.01 \\
\hline P O & 0.06 & 0.07 & 0.08 & 0.08 & 0.17 & 0.19 & 0.06 & 0.16 & 0.16 & 0.16 & 0.04 & 0.06 \\
\hline LOI & 1.12 & 1.28 & 3.53 & 2.19 & 1.00 & 1.17 & 1.92 & 4.57 & 3.20 & 2.27 & 2.14 & 1.46 \\
\hline SUM & 99.62 & 99.87 & 98.23 & 99.62 & 99.91 & 99.84 & 99.67 & 99.80 & 99.74 & 99.98 & 99.86 & 99.85 \\
\hline $\mathbf{S}$ & 0.00 & 0.00 & 0.02 & 0.00 & 0.00 & 0.00 & 0.00 & 0.00 & 0.00 & 0.00 & $<0.01 \%$ & $<0.01 \%$ \\
\hline As & 3 & 2 & $1.3 \% *$ & 252 & 7 & 9 & 22 & 1 & $<1$ & 1 & $<1$ & $<1$ \\
\hline Ba & 104 & 52 & 287 & 129 & 15 & 44 & 79 & 89 & 40 & 36 & 42 & 21 \\
\hline $\mathrm{Ce}$ & 11 & 11 & 15 & 7 & 31 & 43 & 15 & 38 & 31 & 23 & $<5$ & 15 \\
\hline $\mathrm{Cr}$ & 583 & 555 & 101 & 1140 & 86 & 65 & 595 & 93 & 126 & 115 & 1253 & 1296 \\
\hline Cu & 143 & 27 & 130 & 46 & 27 & 68 & 53 & 21 & 62 & 130 & 27 & 6 \\
\hline Ga & 15 & 16 & 21 & 16 & 21 & 17 & 15 & 21 & 19 & 20 & 13 & 15 \\
\hline $\mathbf{L a}$ & $<5$ & $<5$ & $<5$ & $<5$ & 15 & $<5$ & $<5$ & $<5$ & 13 & $<5$ & $<5$ & $<5$ \\
\hline $\mathbf{N b}$ & $<1$ & $<1$ & $<1$ & $<1$ & 8 & 9 & $<1$ & 8 & 7 & 8 & $<1$ & $<1$ \\
\hline $\mathrm{Ni}$ & 148 & 155 & 45 & 194 & 51 & 47 & 159 & 52 & 63 & 59 & 373 & 342 \\
\hline $\mathbf{P b}$ & 3 & 5 & 15 & 5 & 5 & 6 & 5 & 5 & 6 & 2 & 4 & 3 \\
\hline $\mathbf{R b}$ & 15 & 9 & 60 & 57 & 3 & 3 & 12 & 7 & 4 & 3 & 7 & 4 \\
\hline Sc & 36 & 36 & 36 & 25 & 31 & 34 & 40 & 33 & 39 & 35 & 30 & 36 \\
\hline $\mathbf{S r}$ & 127 & 120 & 35 & 116 & 70 & 104 & 189 & 114 & 104 & 106 & 87 & 120 \\
\hline Th & $<1$ & $<1$ & $<1$ & $<1$ & 4 & 2 & $<1$ & $<1$ & $<1$ & 2 & $<1$ & $<1$ \\
\hline $\mathbf{U}$ & $<1$ & $<1$ & $<1$ & 2 & $<1$ & $<1$ & 1 & 2 & 2 & $<1$ & $<1$ & $<1$ \\
\hline V & 223 & 204 & 261 & 222 & 299 & 281 & 222 & 306 & 345 & 316 & 193 & 226 \\
\hline $\mathbf{Y}$ & 20 & 17 & 20 & 13 & 34 & 36 & 18 & 35 & 34 & 30 & 14 & 18 \\
\hline $\mathrm{Zn}$ & 73 & 78 & 45 & 39 & 110 & 123 & 65 & 111 & 117 & 114 & 77 & 80 \\
\hline $\mathbf{Z r}$ & 70 & 66 & 80 & 68 & 140 & 153 & 69 & 141 & 149 & 140 & 58 & 62 \\
\hline
\end{tabular}

* Data outside calibration range.

$<$ Denotes data below detection limit.

${ }^{\#} \mathrm{Fe}^{2+}$ analysed at Albert-Ludwigs-Universität Freiburg, Germany, by titration: MG313 $=6.87 \%$;

MG314 = $6.93 \% ;$ MG327 = 3.72\%; CRM2115 Fe2+ = 8.54\% (cf. stated value Fe2+ = 8.50\%) 


\begin{tabular}{|c|c|c|c|c|c|c|}
\hline & MG353 & TF02 & TF06 & TF08 & TF10 & TF12 \\
\hline $\mathrm{SiO}_{2}$ & 44.80 & 47.27 & 45.51 & 46.29 & 52.54 & 49.17 \\
\hline $\mathrm{TiO}_{2}$ & 0.71 & 1.30 & 1.15 & 1.35 & 1.31 & 1.17 \\
\hline $\mathbf{A l}_{2} \mathbf{O}_{3}$ & 14.29 & 15.04 & 13.55 & 16.03 & 13.01 & 14.07 \\
\hline $\mathrm{Fe}_{2} \mathrm{O}_{3}$ & 14.49 & 12.79 & 11.67 & 13.14 & 7.66 & 11.28 \\
\hline MnO & 0.24 & 0.15 & 0.17 & 0.16 & 0.15 & 0.18 \\
\hline MgO & 10.58 & 4.92 & 4.64 & 7.03 & 6.41 & 5.89 \\
\hline $\mathrm{CaO}$ & 11.52 & 10.73 & 13.05 & 8.25 & 8.90 & 9.16 \\
\hline $\mathrm{Na}_{2} \mathrm{O}$ & 1.57 & 0.36 & 0.70 & 0.70 & 5.32 & 4.23 \\
\hline $\mathrm{K}_{2} \mathrm{O}$ & 0.22 & 1.60 & 0.97 & 1.29 & 0.30 & 0.71 \\
\hline $\mathrm{SO}_{3}$ & 0.04 & 0.81 & 1.04 & 0.21 & 0.36 & 0.48 \\
\hline $\mathbf{P}_{2} \mathbf{O}_{5}$ & 0.07 & 0.13 & 0.11 & 0.15 & 0.13 & 0.13 \\
\hline LOI & 1.42 & 4.50 & 7.09 & 4.96 & 3.82 & 3.32 \\
\hline SUM & 99.94 & 99.61 & 99.64 & 99.56 & 99.92 & 99.79 \\
\hline $\mathbf{S}$ & 0.00 & 0.00 & 0.00 & 0.00 & 0.00 & 0.00 \\
\hline As & 6 & 1766 & 756 & 139 & 21 & 16 \\
\hline $\mathbf{B a}$ & 24 & 240 & 175 & 194 & 63 & 137 \\
\hline $\mathrm{Ce}$ & 19 & 22 & 19 & 25 & 19 & 25 \\
\hline $\mathrm{Cr}$ & 1539 & 312 & 291 & 335 & 312 & 275 \\
\hline $\mathrm{Cu}$ & 35 & 81 & 130 & 79 & 134 & 159 \\
\hline Ga & 17 & 20 & 18 & 23 & 10 & 17 \\
\hline La & $<5$ & $<5$ & 10 & $<5$ & 14 & $<5$ \\
\hline Nb & $<1$ & 7 & $<1$ & $<1$ & 7 & 7 \\
\hline $\mathbf{N i}$ & 398 & 95 & 77 & 102 & 58 & 84 \\
\hline $\mathbf{P b}$ & 6 & 10 & 10 & 7 & 10 & 7 \\
\hline $\mathbf{R b}$ & 4 & 48 & 20 & 24 & 5 & 16 \\
\hline Sc & 42 & 26 & 28 & 34 & 29 & 35 \\
\hline $\mathrm{Sr}$ & 79 & 165 & 147 & 163 & 75 & 149 \\
\hline Th & $<1$ & $<1$ & $<1$ & 2 & 2 & $<1$ \\
\hline $\mathbf{U}$ & $<1$ & $<1$ & 2 & $<1$ & $<1$ & $<1$ \\
\hline V & 242 & 259 & 244 & 301 & 218 & 268 \\
\hline $\mathbf{Y}$ & 20 & 28 & 32 & 30 & 36 & 29 \\
\hline Zn & 102 & 100 & 82 & 113 & 422 & 101 \\
\hline $\mathrm{Zr}$ & 72 & 118 & 106 & 123 & 121 & 111 \\
\hline
\end{tabular}

* Data outside calibration range.

$<$ Denotes data below detection limit. 